\title{
Arbeidsverdeling, normatieve integratie en typen van afwijkend gedrag
}

Citation for published version (APA):

Drop, M. J. (1979). Arbeidsverdeling, normatieve integratie en typen van afwijkend gedrag. [Doctoral Thesis, Maastricht University]. Rijksuniversiteit Limburg. https://doi.org/10.26481/dis.19790406md

Document status and date:

Published: 01/01/1979

DOI:

10.26481/dis.19790406md

Document Version:

Publisher's PDF, also known as Version of record

\section{Please check the document version of this publication:}

- A submitted manuscript is the version of the article upon submission and before peer-review. There can be important differences between the submitted version and the official published version of record.

People interested in the research are advised to contact the author for the final version of the publication, or visit the DOI to the publisher's website.

- The final author version and the galley proof are versions of the publication after peer review.

- The final published version features the final layout of the paper including the volume, issue and page numbers.

Link to publication

\footnotetext{
General rights rights.

- You may freely distribute the URL identifying the publication in the public portal. please follow below link for the End User Agreement:

www.umlib.nl/taverne-license

Take down policy

If you believe that this document breaches copyright please contact us at:

repository@maastrichtuniversity.nl

providing details and we will investigate your claim.
}

Copyright and moral rights for the publications made accessible in the public portal are retained by the authors and/or other copyright owners and it is a condition of accessing publications that users recognise and abide by the legal requirements associated with these

- Users may download and print one copy of any publication from the public portal for the purpose of private study or research.

- You may not further distribute the material or use it for any profit-making activity or commercial gain

If the publication is distributed under the terms of Article $25 \mathrm{fa}$ of the Dutch Copyright Act, indicated by the "Taverne" license above, 


\title{
ARBEIDSVERDELING, NORMATIEVE INTEGRATIE \\ EN TYPEN VAN AFWIJKEND GEORAG
}

\begin{abstract}
PROEFSCHRIFT
ter verkrijging van de graad van doctor in de sociale wetenschappen aan de Rijksuniversiteit Limburg, op gezag van de Rector Magnificus Dr. W.H.F.W. Wijnen, hoogleraar in de faculteit der geneeskunde, volgens besluit van het College van Dekanen in het openbaar te verdedigen op vrijdag 6 april 1979, des namiddags om 16.00 uur precies, in de aula der universiteit
\end{abstract}

door

MARIA JOHANNA DROP

geboren te 's-Gravenhage in 1935 
Promotor: Prof.Dr. H. Philipsen

Coreferenten: Prof.Dr. C.E. Vervoort

Prof.Dr. M.A.J. Romme

Het onderzoek werd uitgevoerd op het Nederlands Instituut voor Preventieve Geneeskunde/TNO 
Aan de nagedachtenis van Wies Drop-Meijer Aan Elselien 
Manuscript: Mevr. L. Royen-Warnars

Tekeningen: Mevr. E.J. Deutekom

Fotografie en omslag: G. van Rooy

Druk: B. Meerstad 
INHOUDSOPGAVE

INLEIDING

pag.

DEEL I

OPZET, RESULTATEN EN ONTWIKKELING VAN HET GEMEENTEKENMERKENONDERZOEK

HOOFOSTUK 1 ANALYSENIVEAU EN PROBLEEMSTELLINGEN VAN HET ONDERZOEK

1.1 De ạanvankelijke doelstelling van het onderzoek

1.2 De keuze van het analyseniveau: de gemeente als eenheid van onderzoek

1.3 De keuze van de welzijns- en gezondheidsindikatoren

1.4 De probleemstelling en de fasering van het onderzoek

HOOFDSTUK 2 SAMENVATTING VAN DE RESULTATEN VAN DE EERSTE ONDERZOEKSFASE

2.1 De selektie van de onderzoekspopulatie 24

2.2 De selektie van de gedragsvariabelen 26

2.3 De betrouwbaarheid en geldigheid van de gedragsvariabelen

2.4 Dimensies in het afwijkend en ziektegedrag

HOOFDSTUK 3 UITGANGSPUNTEN EN RESULTATEN VAN DE TWEEDE ONDERZOEKSFASE

3.1 Het verkennend karakter van het onderzoek

3.2 Samenvatting van literatuur over theorie en onderzoek naar aard en oorzaken van afwijkend en ziektegedrag

3.3 Samenvatting van literatuur over ecologisch onderzoek naar voorkomen en spreiding van afwijkend en ziektegedrag

3.4 Kenmerken van gemeenten en hun onderlinge samenhangen

3.5 Relaties tussen de dimensies in de gemeentekenmerken en de onderscheiden gedragsfaktoren 
DEEL II

SOCIALE BEHEERSING EN TYPEN VAN AFWIJKEND

pag. GEDRAG - ONTWIKKELING EN TOETSING VAN EEN THEORETISCH MODEL

HOOFDSTUK 4 INLEIDING IN HET THEMA - UITGANGSPUNTEN VAN HET MODEL

4.1 Uitgangspunten van het mode 1

4.2 Relevante aspekten van het sociale beheersingssysteem

4.3 De bindingskracht van het normatieve systeem

4.4 Kerkelijke gezindte, criminaliteit en sociale beheersing: een illustratieve relatie

4.4.1 De criminaliteit van Nederlandse rooms-katholieken

4.4.2 Overeenkomsten met thema's uit de sociologische literatuur

HOOFDSTUK 5 ONTWIKKELING VAN HET THEORETISCHE MODEL

5.1 Sociale beheersing en de variabiliteit van het gedrag - de theorie van Durkheim

5.1.1 Normatieve integratie en de invariabiliteit van het gedrag

5.1.2 De gevolgen van de arbeidsverdeling

5.1.3 Funktionele interdependentie en de variabiliteit van het gedrag

5.2 Het Durkheimiaanse model van Webb

5.3 Evaluatie van Webb's onderzoek -konsekwenties voor het sociale beheersingsmodel

5.3.1 Het operationele systeem van Webb

5.3.2 Het ontwikkelingspeil van de samenleving als konditie voor het model

5.3.3 Uitbreiding en wijziging van Webb's conceptuele model

5.3.4 Webb's operationalisering van de kriteriumvariabelen

5.4 De concepten variabiliteit en invariabiliteit van het gedrag 
HOOFDSTUK 6 FORMULERING VAN HET THEORETISCHE MODEL

- SAMENVATTING EN PROPOSITIES

pag.

110

110

6.1 Samenvatting

112

6.2 De proposities

- INDIKATOREN EN HYPOTHESEN

118

7.1 De keuze van de indikatoren

124

7.2 De hypothesen

127

HOOFDSTUK 8 TOETSING VAN HET MODEL I: DE RELATIES TUSSEN DE ONAFHANKELIJKE VARIABELEN VAN HET MODEL

8.1 Resultaten hypothese 1

8.2 Resultaten hypothesen 2, 3, 4 en 5

8.3 Resultaten hypothesen 6 en 7

8.4 Resultaten hypothesen 8 en 9

HOOFDSTUK 9 TOETSING VAN HET MODEL II: DE RELATIES TUSSEN DE ONAFHANKELIJKE EN DE AFHANKELIJKE VARIABELEN

9.1 Resultaten hypothese 10

9.2 Resultaten hypothese 11

9.3 Resultaten hypothese 12

9.4 Resultaten hypothesen 13 en 14

HOOFDSTUK 10 SAMENVATTING EN KONKLUSIES: ARBEIDSVERDELING, NORMATIEVE INTEGRATIE EN TYPEN VAN AFWIJKEND GEORAG

10.1 Samenvatting van de onderzoeksuitkomsten

10.2 Bespreking van de onderzoeksuitkomsten

10.2.1 Bespreking van de toetsingsresultaten voor de onafhankelijke variabelen

10.2.2 Bespreking van de toetsingsresultaten voor de afhankelijke variabelen

10.2.3 Bespreking van de niet-voorspelde resultaten

10.3 Evaluatie en konklusies: naar een algemene theorie over de relatie tussen eigenschappen van de sociale beheersing en typen van afwijkend gedrag 
HOOFDSTUK 11 SUGGESTIES VOOR DE VERDERE TOETSING EN

pag. ONTWIKKELING VAN DE THEORIE

11.1 Herhaalde toetsing van het model

11.2 Ontwikkeling van de theorie: funktionele interdependentie en de invariabiliteit van het gedrag

11.2.1 Durkheim's toekomstvisie als aanknopingspunt voor de verdere ontwikkeling van de theorie

11.2.2 Uitgangspunten en veronderstellingen voor de nadere uitwerking van de theorie

NOTEN

SUMMARY

BIJLAGEN

DANKWOORD 


\section{BIJLAGEN}

Lijst van onderzoeksgemeenten, ingedeeld naar urbanisatiecategorie, met vermelding van provincie

Lijst van variabelen

Resultaten orthogonale componentenanalyse, uitgevoerd op de correlatiematrix van 30 gedragsvariabelen voor 176 Nederlandse gemeenten

Rangordening gemeenten van hoge naar lage faktorscores, ingedeeld in kwartielen: Vluchtgedrag, Agressief gedrag en Vatbaarheid

Spreidingsbreedte, centrale tendentie en verdeling over de hoofdurbanisatiecategorieën van variabelen betreffende de fysiek-morfologische, socioeconomische, economische, sociokulturele en demografische kenmerken en de voorzieningen van de gemeenten (tabellen $1 \mathrm{t} / \mathrm{m}$ 6) V 1-4

Resultaten orthogonale componentenanalyse, uitgevoerd op 67 kenmerken van 176 gemeenten: Principale componenten en Varimax rotatie

Rangordening gemeenten van hoge naar lage faktorscores, ingedeeld in kwartielen: Welstand - stedelijkheid, Stagnerende groei - vergrijzing, Godsdienst, Onderwijsfaciliteiten, Stedelijkheid - voorzieningendeprivatie en Industrie

Nulde-orde correlaties en vierde-orde partiële correlaties tussen de onafhankelijke variabelen van het operationele model

Nulde-orde correlaties van de onafhankelijke variabelen met de afhankelijke variabelen van het operationele model 
- 


\section{INLEIDING}

In deze studie worden in hoofdzaak de resultaten beschreven van de toetsing van een theoretisch model, waarin het voorkomen en de spreiding van verschillende vormen van afwijkend gedrag in verband worden gebracht met bepaalde eigenschappen van het maatschappelijk systeem van sociale beheersing. Zowel de rapportage van deze studie als het model hebben een tamelijk lange voorgeschiedenis.

Het model werd ontwikkeld in de loop van een onderzoek, dat oorspronkelijk vanuit een geheel andere doelstelling werd ondernomen. Dit onderzoek, bekend onder de aanduiding 'Kenmerken van gemeenten en verschillen in ziekte- en afwijkend gedrag' werd in de periode van 1969 tot en met 1972 uitgevoerd op het Nederlands Instituut voor Preventieve Geneeskunde/TNO.

De rapportage van de uitkomsten werd op het N.I.P.G./TNO begonnen en met enkele jaren onderbreking tenslotte aan de Rijksuniversiteit Limburg in de vorm van dit proefschrift voltooid.

De aanvankelijke doelstelling van het onderzoek had betrekking op de vraag naar de samenhang tussen welzijn en gezondheid en de hoedanigheden van de fysieke, sociaaleconomische en kulturele omgeving. Daarbij werden welzijn en gezondheid niet opgevat als eigenschappen van individuen, maar als maatschappelijke verschijnselen met eigen oorzaken en spreidingspatronen.

In de oorspronkelijke onderzoeksopzet werd gekozen voor een ecologische benadering, dat wil zeggen, dat de vraagstelling niet werd onderzocht op individuen, maar op bovenindividuele eenheden, i.c. gemeenten.

Behalve op een persoonlijke belangstelling voor de mogelijkheden en onmogelijkheden van een analyse op secundaire, statistische gegevens, berustte de keuze van deze benadering op de overweging, dat hoewel er vaak en veel gesproken wordt over 'de' morbiditeit, 'de' echtscheiding, 'de' criminaliteit e.d., onderzoek naar deze verschijnselen als zodanig relatief schaars is. Vóórkomen en spreiding zijn dikwijls wel bekend, maar veelal ontbreekt informatie over de samenhang daarvan met maatschappelijke faktoren en ontwikkelingen. Een dergelijke gedachtengang kwam ook naar voren in de zgn. 'social indicator' literatuur van de eind zestiger jaren, 
begin zeventiger jaren.

Deze literatuur weerspiegelde de in die periode snelgroeiende, vooral vanuit de beleidsbehoeften van de overheid gestimuleerde, belangstelling voor de ontwikkeling en toepassing van indikatoren: gedurende langere perioden voor verschillende sektoren van de samenleving geregistreerde gegevens.

In analogie met de economische gegevens zouden deze indikatoren ontwikkeld moeten worden ten behoeve van onderzoek en beleid op sociaal en kultureel gebied, waaronder met name ook de gezondheid, het welzijn van de bevolking, úe kwaliteit van het bestaan.

Deze doelstellingen van de zgn. 'social indicator movement', alsook de uiteenlopende meningen daarover komen duidelijk tot uiting in een aantal speciaalnummers van de The Annals of the American Academy of Political and Social Science (vol. 371 en 373, 1967) en van Management Science (vol. 16, no. 12, 1970). Deze en dergelijke literatuur speelde een belangrijke rol bij de keuze van zowel het onderwerp en de vraagstelling als het analyseniveau van het onderzoek. De keuze van de gemeente als de eenheid van analyse, alsook de selektie van de 176 Nederlandse gemeenten waarop het onderzoek werd uitgevoerd, berustte vooral op praktische overwegingen.

Ditzelfde gold voor de indikatoren van welzijn en gezondheid of liever van de afwezigheid daarvan -voor de verschillende vormen van ziekte- en afwijkend gedrag was de beschikbaarheid van gemeentelijke gegevens een belangrijk selektiekriterium.

Voor verreweg de meeste gemeentekenmerken was ten tijde van het onderzoek -en tot voor kort nog steeds- de $13 \mathrm{e}$ Algemene Volkstelling van 31 mei 1960 de meest recente bron van gegevens. Daarom werden ook de gegevens voor de gedragsvariabelen verzameld voor de jaren rond 1960. Omdat spoedig bleek dat de verzameling van de gegevens voor de gedragsvariabelen over die periode nogal wat problemen zou opleveren werd besloten de eerste fase van het onderzoek daartoe te beperken. In deze eerste fase werden ook de onderlinge samenhangen van de gedragsvariabelen onderzocht. Over de uitkomsten van deze analyse werd eerder verslag gedaan in een interim-rapport (Drop, 1971). Omdat deze resultaten echter van belang zijn voor de toetsing van het later on twikkelde theoretische model zullen ze hier opnieuw, kort samengevat, worden weergegeven. 
Voorafgegaan door een uitvoerige literatuurstudie werden in de tweede fase van het onderzoek de gegevens verzameld voor een tamelijk groot aantal gemeentekenmerken die verondersteld werden op enigerlei wijze verband te houden met de eerder gekonstateerde verschillen in frekwentie van afwijkend en ziektegedrag.

De geëxtraheerde faktoren bleken, zij het in wisselende mate, inderdaad te correleren met de onderscheiden gedragsdimensies. De interpretatie van deze correlaties werd echter bemoeilijkt door het ontbreken van een theoretisch kader.

Eerder werden in de literatuur verschillende, meer of minder, geslaagde pogingen tot de ontwikkeling van een theoretisch interpretatiekader voor de differentiële spreiding van afwijkend gedrag aangetroffen. Daarbij werd, vooral ten aanzien van agressieve criminaliteit en zelfmoord relatief veel aandacht besteed aan het begrip sociale integratie, veelal onder verwijzing naar Durkheim's theoretische beschouwingen over de zelfmoord.

In enkele studies werd evenwel een poging ondernomen tot de operationalisering en toetsing van de theorie van Durkheim over de ontwikkeling van de arbeidsverdeling en de daarmee gepaard gaande verschijnselen.

Deze studies inspireerden tot een derde en laatste fase van het onderzoek waarin het in dit verslag beschreven theoretische model over de arbeidsverdeling, normatieve integratie en typen van afwijkend gedrag werd ontwikkeld en getoetst. 
I OPZET, RESULTATEN EN ONTWIKKELING VAN HET GEMEENTEKENMERKEN ONDERZOEK.

1.1 De anvankelijke doelstelling van het onderzoek

Het theoretisch model, waarop dit verslag in hoofdzaak betrekking heeft, resulteerde uit een onderzoek, dat oorspronkelijk vanuit een andere doelstelling werd ondernomen. De aanvankelijke doelstelling kan, kort samengevat, worden omschreven als een poging inzicht te verkrijgen in wedzijn en gezondheid als maatschappelijke verschijnselen, in hun relatie met andere sociale verschijnselen, op een niveau, waarop beleidsinstanties met deze problemen te maken hebben en waarop ze zelf veelal opereren. Vanuit deze doelstelling werd het onderzoek verricht op boven-individuele eenheden, in de sociale ecologie aangeduid met het verzamelbegrip 'community'. Een 'community' (regio, stad, dorp, buurt, woning) wordt in het algemeen beschouwd als te zijn opgebouwd uit een aantal mensen, een bepaald grondgebied, waarop deze mensen verblijven en een reeks van aktiviteiten van deze mensen op dat grondgebied.

Voor deze struktuurelementen van de 'community' worden doorgaans de begrippen populatie, habitat en voorzieningen gebruikt (Nelissen, 1972).

In deze terminologie gesproken ging het bij de opzet van het onderzoek dus om samenhangen van welzijn en gezondheid als eigenschappen van de populatie met andere, in dit verband van belang te achten kenmerken van de populatie, de habitat en de voorzieningen van een aantal 'communities'. De analyse en interpretaties van dergelijke samenhangen blijken nogal eens tot problemen en misverstanden aanleiding te geven.

Het lijkt daarom van belang nu reeds wat dieper op deze problematiek in te gaan, dit ook omdat, zoals later nog zal worden besproken, de beslissing om af te zien van de oorspronkelijke doelstelling en opzet van het onderzoek voor een belangrijk deel werd ingegeven door de mozilijkheden ondervonden bij de interpretatie van de betekenis van de gevonden correlaties.

Bedoelde problemen en misverstanden betreffen de 'fout van het verkeerde niveau' ('fallacy of the wrong level') 
en meer specifiek de 'ecological fallacy', waarbij samenhangen tussen eigenschappen van boven-individuele eenheden ('ecological correlations') ten onrechte worden vertaald in samenhangen tussen eigenschappen van individuen ('individual correlations'). (Galtung, 1969)

In een veel geciteerd artikel toont Robinson (1950) mathematisch aan, dat ecologische correlaties niet op geldige wijze verwisseld kunnen worden met individuele correlaties, daarbij al doende het gebruik van ecologische correlaties afwijzend.

Menzel (1950) stelt echter in zijn kommentaar, daarin bijgevallen door Goodman (1953) en Duncan en Davis (1953), dat, hoe juist de konklusie omtrent de ongeldigheid van de vervanging van individuele door ecologische correlaties ook moge zijn, daarmee nog niet is gezegd, dat ecologische correlaties als zodanig geen betekenis zouden hebben. Ecologische correlaties tussen verschijnselen bezitten geldigheid niet alleen in geval de desbetreffende verschijnselen zijn te beschouwen als funkties van gemeenschappelijke, niet in de individuen als zodanig, maar in interindividuele verschillen en relaties ('properties of areas as such') gelegen oorzaken, maar ook indien er sprake is van een meer direkt oorzakelijk verband tussen de verschijnselen: hoewel uit een ecologische correlatie tussen het percentage joden en het percentage antisemieten van een populatie inderdaad niet mag worden gekonkludeerd dat joden antisemieten zijn, wordt met deze correlatie toch wel een betekenisvolle relatie aangegeven. ${ }^{1}$ )

$\mathrm{Nu}$ is het hier aangeduide misverstand niet onbegrijpelijk. In de eerste plaats worden de kenmerken van de struktuurelementen van de 'community', met name die van de populatie, veelal gemeten met behulp van de per 'community' gesommeerde eigenschappen of gedragingen van individuen. In de tweede plaats maken de eigenschappen van de struktuurelementen niet alleen deel uit van een op" 'community' niveau samenhangend complex, maar zijn ze via tussenliggende sociale, psychologische en fysiologische mechanismen, ook van invloed op houding en gedrag van de individuele leden van de 'community' populatie. 
Ook in dit onderzoek werden welzijn en gezondheid, evenals andere kenmerken van de populatie, geoperationaliseerd met behulp van gesommeerde gedragingen en kenmerken van individuen en kan de onderzochte relatie tussen sociokulturele omgeving enerzijds en welzijn/gezondheid anderzijds in termen van verklaringsniveaus worden gezien als te behoren tot zowel een horizontaal als een vertikaal causaal complex. Waar de afhankelijke variabele in dit onderzoek bestaat uit eigenschappen van de populatie -gemeten met de gesommeerde gedragingen van individuen- speelt vrijwel onvermijdelijk ook dit 'vertikale' complex een rol en wel in de min of meer impliciete veronderstelling, die aan de k.euze vall de andere, in dit verband van belang te achten kenmerken van de 'community' ten grondslag ligt. Hiermee wordt bedoeld dat de keuze van de in het onderzoek te betrekken kenmerken van de populatie, habitat en voorzieningen van een 'community' werd gebaseerd op de veronderstelling, dat hoedanigheden van de omgeving, waarvan bekend is dan wel vermoed kan worden, dat zij welzijn en gezondheid van het individu (kunnen) beĩnvloeden, op 'community'niveau een samenhang zullen vertonen met de indikatoren voor het welzijn en de gezondheid van de populatie. In concreto wil dit zeggen, dat 'communities', gekenmerkt door relatief ongunstige woon-, werk- en leefomstandigheden (bv. woningnood, werkeloosheid, sociokulturele deprivatie), werden verondersteld ook relatief hoge cijfers voor mortaliteit, geestesziekte, zelfmoord e.d. te zullen vertonen. Hoewel bij de keuze van de onafhankelijke variabelen overwegingen betreffende de (vermoedelijke) relaties binnen het 'vertikale' complex (omgeving - individu) mede een rol speelden, konden strikt genomen de resultaten van het onderzoek uitsluitend informatie verschaffen over de relaties binnen het 'horizontale' complex, namelijk over de samenhangen tussen kenmerken van de struktuurelementen van de onderzochte 'communities'.

De vraag of de ecologische correlaties mogen worden vertaald in analoge individuele correlaties, met andere woorden, of samenhangen, zoals hiervoor aangegeven zo moger. worden ge- 
interpreteerd als zouden bv. woningzoekenden zich kenmerken door een hoge sterfte, werkelozen geestesziek worden dan wel sociaalkultureel gedepriveerde personen zelfmoord plegen, kan alleen worden beantwoord door onderzoek waarbij ook metingen op individueel niveau worden verricht.

1.2 De keuze van het analyseniveau: de gemeente als eenheid van onderzoek

Wat betreft de concrete inhoud van het hiervoor genoemde begrip 'communities' deden zich in principe vier mogelijkheden voor: provincies, economisch-geografische gebieden, gemeenten en buurten.

De keuze van de gemeente berust op de kombinatie van twee praktische kriteria: de beschikbaarheid van de gegevens en de omvang van de onderzoekspopulatie.

- De door diverse instanties verzamelde en geregistreerde gemeentelijke gegevens vormen een naar verhouding gemakkelijk toegankelijke bron van redelijk bruikbaar secundair materiaal.

- Met name de gegevens op het gebied van welzijn en gezondheid worden niet of nauwelijks per economisch-geografisch gebied geregistreerd en zouden moeten worden verkregen middels optellingen van de desbetreffende gemeentelijke cijfers wat in feite betekent, dat ze voor alle (993) gemeenten zouden moeten worden verzameld. Wat betreft de buurten zijn - op enkele uitzonderingen na- de welzijns- en gezondheidsgegevens in het geheel niet beschikbaar.

- Het aantal gemeenten -993 per 31 mei 1960- waarborgde ook na toepassing van selektiekriteria ter homogenisering van de onderzoekspopulatie, een voor de statistische analyse bevredigende omvang van deze populatie. Hoewel de provincies wat betreft de beschikbaarheid van geregistreerde gegevens, waarschijnlijk de minste moeilijkheden zouden hebben gegeven, zijn ze op grond van hun geringe aantal buiten beschouwing gelaten.

Uit het bovenstaande volgt, dat de gemeente als de 'community' en daarmee dus als de meeteenheid van het onderzoek is gekozen: welzijn en gezondheid, alsook de andere kenmerken van de gemeenten worden gemeten met behulp van geregistreerde gemeentelijke gegevens. Er is dus afgezien van de mogelijkheid om met de survey-methode steekproeven uit de bevolking van een aantal gemeenten te onderzoeken -deels 
vanwege de daaraan verbonden praktische problemen (selektie van. de bij het onderzoek te betrekken gemeenten, zeer grote aantal te houden interviews), deels ook op grond van meer methodologische en theoretische bezwaren, verband houdend met de operationalisering van de variabelen. Galtung (1969) wijst erop, dat in principe de operationali sering van kenmerken van onder- of bovenliggende niveaus tot variabelen op het niveau, waarop het onderzoek betrekking heeft, de sociologische analyse kan verrijken -het biedt de mogelijkheid verschillende niveaus in de analyse te betrekken. In feite gebeurt dit in alle sociologisch onderzoek, dat het individu als de eenhej $\because$ :n ailaiyse heeft en waarin de invloed van de omgeving, de sociale struktuur op het individueel gedrag wordt onderzocht. Daarin worden namelijk de kenmerken van de sociale strukturen, waarin het individu is opgenomen, op individueel niveau geoperationaliseerd met voor anderen waarneembare en bekende kenmerken van het individu, zoals geslacht, leeftijd, beroep, godsdienst e.d. -in de terminologie van Galtung de 'permanent public variables' of ook wel 'background variables'.

Omgekeerd kunnen deze 'permanent public' kenmerken van individuen tot analytische variabelen (=gesommeerde eigenschappen van individuen) worden getransformeerd en als zodanig op boven-individueel niveau de kenmerken van grotere sociale eenheden indiceren, bv. percentage mannen, bejaarden, handarbeiders, rooms-katholieken e.d.. Echter, niet alle omgevings- of struktuurkenmerken laten zich in geaggregeerde kenmerken van individuen vertalen. Zo is het uiteraard niet goed mogelijk kenmerken van de habitat en van de voorzieningen op het gebied van onderwijs, rekreatie, gezondheidszorg e.d., de diversiteit van de economische struktuur, de sociokulturele homogeniteit, de bevolkingsgroei en -dichtheid etc. uitsluitend met behulp van eigenschappen van individuen te meten. Zelfs indien deze en dergelijke eigenschappen van de gemeente op een bevredigende wijze in enquetevragen zouden kunnen worden omgezet, dan nog zouden ze voor een groot deel gemeten worden als herinneringen, percepties van de ondervraagde individuen, dat wil zeggen, met behulp van wat Galtung noemt 'temporal private' variabelen. Pogingen, om met behulp van dergelijk vaak weinig stabiele psychologische kenmerken van individuen, de eigenschappen 
van strukturen te indiceren, worden terecht als 'psychologisch reduktionisme' gekritiseerd.

Duncan en Schnore (1959) wijzen erop, dat de -in de sociologie zo belangrijke- 'behavioral approach' zich veelal bezighoudt met strukturen en organisaties, zoals die door individuen worden gepercipieerd en dat veel minder aandacht wordt besteed aan de konkrete fysieke omgeving of de objektieve kenmerken van de strukturen en organisaties.

Etzioni en Lehman (1967) noemen de reduktionistische theorieën van vele onderzoekers, volgens welke eigenschappen van boven-individuele eenheden tot psychologische dan wel micro-sociologische categorieën kunnen worden teruggebracht, als één van de redenen waarom in sociologisch onderzoek (ten onrechte) zo weinig gebruik wordt gemaakt van globale variabelen ( = eigenschappen van boven-individuele sociale eenheden].

De keuze van de gemeente als de meeteenheid van het onderzoek maakte het mogelijk niet alleen de analytische (dat wil zeggen populatie) kenmerken, maar ook de globale (dat wil zeggen habitat en voorzieningen) kenmerken van de gemeenten bij het onderzoek te betrekken.

Het gebruik van door andere instanties verzameld en bewerkt materiaal is overigens niet zonder problemen. Afgezien van de onmogelijkheid van een direkte kontrole op de betrouwbaarheid en geldigheid van de gegevens (waarover later meer) betekent het wat betreft de keuze van de variabelen een afhankelijkheid van de beschikbaarheid van de gegevens, zowel naar de vorm waarin, als naar de periode waarover ze beschikbaar zijn.

Aangezien het onderzoek voor een belangrijk deel van zijn gegevens was aangewezen op resultaten van de $13 e$ Algemene Volkstelling van 31 mei 1960, zijn de jaren rond 1960 gekozen als de periode, waarop het onderzoek betrekking heeft. Om de door toevallige, met dit onderzoek in ieder geval niet meetbare, faktoren veroorzaakte fluktuaties in de frekwenties zoveel mogelijk uit te schakelen, zijn de verschillende gezondheids- en welzijnsindicatoren berekend als gemiddelden over een periode van vijf jaren, namelijk van 1958 - 1962. Voor de meer konstant te achten sociale, kulturele en economische kenmerken van de gemeenten, werd gebruik gemaakt van gegevens uit 1960. Ook de selektie van de onderzoekspopulatie is op gegevens uit dat jaar gebaseerd. 
In in dit onderzoek worden gegevens transversaal en voor eenzelfde periode gemeten. Dit betekent dat gewaakt moet worden tegen wat kan worden genoemd de 'fallacy of the time lag', een probleem dat zich ongeacht het niveau van analyse, voordoet in elk transversaal onderzoek waarin niet uitdrukkelijk wordt uitgegaan van de gelijktijdigheid in het voorkomen van de gerelateerde verschijnselen.

Deze fout wordt begaan in het geval op grond van samenhangen tussen transversaal gemeten gegevens uitspraken over het causale of procesmatige karakter van de relaties worden gedaan.

Ook indien enerzijds de hypothesen over de relaties werden gebaseerd op een vooronderstelde causaliteit of althans een tijdsvolgorde van de verschijnselen en anderzijds de hypothesen door de transversaal gemeten gegevens worden bevestigd dan nog kan aan de resultaten geen bewijs voor de veronderstelde causaliteit of procesmatigheid van de relaties worden ontleend.

1.3 De keuze van de welzijns- en gezondheidsindicatoren

Zoals al eerder gezegd, zijn welzijn en gezondheid, als eigenschappen van de populatie van een gemeente, moeilijk anders dan met analy issche variabelen te meten, dat wil zeggen met per gemeente gesommeerde objektieve eigenschappen van individuen.

In concreto betekent dit, dat de verschijnselen welzijn en gezondheid werden geindiceerd met de gemeentelijke frekwenties van een aantal individuele gedragsvormen.

Het gemis aan algemeen geaksepteerde en preciese definities van welzijn en gezondheid anders dan in termen van de afwezigheid van onwelzijn en ziekte, sluit de mogelijkheid uit deze verschijnselen positief te indiceren. Dit geldt zeker in geval er gebruik gemaakt wordt van geregistreerde gegevens, zelfs al zouden er in principe positieve indicatoren zijn aan te wijzen dan nog worden daarover in feite geen gegevens geregistreerd.

Dit brengt met zich mee dat welzijn en gezondheid noodzakelijkerwijs in negatieve zin, namelijk als de afwezigheid ervan, moesten worden gemeten, in concreto met de per gemeente gesommeerde frekwenties van geregistreerd individueel afwijkend en ziektegedrag.

Ofschoon met deze globale omschrijving natuurlijk wel een domein van mogelijke indicatoren min of meer is afgebakend 
is het -gezien de vage, grenzen tussen normaal en afwijkend, tussen gezond en ziek- nog niet onmiddellijk evident wat nu in feite onder afwijkend en ziektegedrag moet worden verstaan. Kort samengevat kan worden gezegd, dat in de meest gangbare definitie van afwijkend gedrag als normoverschrijdend gedrag, de benoeming van gedrag als deviant in feite afhankelijk wordt gesteld van niet alleen de handeling zelf, maar ook van de norm, die wordt overschreden en van de sociale beheersingsmechanismen, waardoor normen en sankties worden toegepast. Ten aanzien van afwijkend gedrag moet daarom, behalve met de 'behavior producing processes' (Kitsuse en Cicourel, 1963), ook rekening worden gehouden met de processen, waardoor normen en gedragsregels tot stand komen (Akers, 1968) en met de rol van wat Erikson (1962) de 'social audience' noemt bij de bepaling welke handelingen al dan niet als afwijkend zullen worden beoordeeld.

Wat betreft dit latste maken Kitsuse en Cicourel het voor dit onderzoek belangrijke onderscheid tussen afwijkend gedrag en het als afwijkend geregistreerde gedrag. Zijwijzen erop, dat met betrekking tot de frekwenties van het geregistreerde afwijkende gedrag rekening moet worden gehouden met de faktoren, die op deze registratie van invloed zijn, de 'rates producing processes'.

Ditzelfde geldt voor het ziektegedrag, welk begrip als een operationele omschrijving kan worden gebruikt voor het onderscheid tussen ziek en gezand: iemand is ziek, indien hij zich ziek gedraagt.

Inzoverre dit ziektegedrag kontakten met medische instanties inhoudt, zijn de eigenschappen, normen en behandelingscapaciteiten van deze instanties mede bepalend voor de behandeling en daarmee dus voor de kans op de registratie van dit ziektegedrag.

Deze konklusie was natuurlijk voor dit onderzoek niet zonder betekenis.

In de eerste plaats kan worden gesteld, dat indicatoren voor de in negatieve zin gemeten gezondheids- en welzijnstoestand van de gemeentebevolking zich noodzakelijkerwijs beperkten tot de gemeentelijke frekwenties van geregistreerd ziektegedrag, alsook van die gedragingen, waarover in de samenleving consensus bestaat aangaande hun normoverschrijdend karakter en die daarbij matschappelijk dusdanig als een probleem worden beschouwd, dat specifieke instanties ter behandeling, korrektie of registratie in het leven zijn geroepen. In de 
tweede plaats zou met betrekking tot de gemeentelijke frekwenties van het geregistreerde ziekte- en afwijkend gedrag rekening moeten worden gehouden met een mogelijke beinvloeding door de eigenschappen en aktiviteiten van de onderscheijen registrerende instanties.

\subsection{De probleemstelling en de fasering van het onderzoek}

Met de gemeente als de eenheid van analyse en de omschrijving van de welzijns- en gezondheidsindicatoren als de gemeentelijke frekwenties van bepaalde vormen van geregistreerd ziekte- en afwijkend gedrag kon de doelstelling van het onderzoek worden gekonkretiseerd in de volgende, vour empirisch onderzoek beter toegankelijke probleemstellingen:

1. is het mogelijk verschillende dimensies in de op gemeenteniveau gemeten gedragsvormen te onderscheiden,

2. vertonen sociale, kulturele, economische kenmerken van gemeenten een samenhang met de frekwenties, waarin verschillende vormen van geregistreerd ziekte- en afwijkend gedrag zich in de gemeenten voordoen,

3. kunnen de tussen de gemeenten bestaande verschillen in het voorkomen van ziekte- en afwijkend gedrag uit deze samenhangen worden verklaard.

Vanwege zijn omvang, vooral wat betreft de verzameling en verwerking van de gegevens, werd besloten het onderzoek in fasen uit te voeren.

Bij een eerste oriëntatie bleek al spoedig, dat de verzameling van de gegevens betreffende het ziekte- en afwijkend gedrag waarschijnlijk de grootste problemen zou opleveren. Daarom werd eerst nagegaan of voor een voldoende aantal gedragsvariabelen gegevens konden worden verkregen, waarop de voortzetting van het onderzoek zou kunnen worden gebaseerd.

Daarbij werd tevens aandacht besteed aan de vraag of en in welke mate de gemeentelijke frekwenties van de verschillende vormen van geregistreerd ziekte- en afwijkend gedrag worden beínvioed door eigenschappen van de registrerende instanties.

De resultaten hiervan werden weergegeven in het eerder genoemde interim-rapport, alsook in een tweetal artikelen (Drcp, 1970; Drop, 1972).

Dit eindrapport betreft de laatste fase en daarmee de centrale probleemstelling van het onderzoek: de samenhang 
tussen kenmerken van gemeenten en de frekwenties van afwijkend en ziektegedrag. Omdat, zoals eerder werd opgemerkt, bij de toetsing van het in deze laatste fase ontwikkelde model gebruik wordt gemaakt van de resultaten van de eerste fasen van het onderzoek, wordt in het volgend hoofdstuk een korte samenvatting van deze uitkomsten gegeven. 
2.1 De selektie van de onderzoekspopulatie

In dit onderzoek ging het niet om een voor alle Nederlandse gemeenten geldende beschrijving van het voorkomen van ziekteen afwijkend gedrag, maar om het vaststellen van relaties tussen gemeentekenmerken en de frekwenties van een aantal deviante gedragsvormen. In dat geval vormt bij de bepaling van de onderzoekspopulatie de specificering van de kondities, waaronder de gevonden samenhangen gelden, een belangrijker uitgangspunt dan het streven naar refresentativiteit (Philipsen, 1969a).

De gemeenten in dit onderzoek vormen den ook geen representatieve steekproef uit alle in 1960 bestaande gemeenten, maar een nauwkeurig omschreven subuniversum daarvan.

De kriteria ter selektie van dit subuniversum hebben in hoofdzaak betrekking op de grootte en op de geografische homogeniteit van de gemeenten.

Wat betreft de grootte -gemeten naar inwonertal- werden buiten beschouwing gelaten alle gemeenten met minder dan 5000 inwoners en de vier gemeenten met meer dan 200.000 inwoners (Amsterdam, Rotterdam, Den Haag en Utrecht). De gemeenten met minder dan 5000 inwoners werden niet opgenomen vanwege de te verwachten zeer geringe aantallen, zo niet de volledige afwezigheid, van bepaalde vormen van afwijkend gedrag. De vier grote steden werden buiten beschouwing gelaten vanwege:

- de aantrekkingskracht die grote steden in het algemeen op zich non-conformistisch of afwijkend gedragende personen plegen uit te oefenen, welk selektieproces de frekwenties van het afwijkend gedrag in een niet vast te stellen mate kan beĩnvloeden;

- het zeer specifieke karakter van met name de havensteden Amsterdam en Rotterdam, en van Den Haag als 'ambtenarenstad';

- de grote mate van heterogeniteit van deze gemeenten, welke zich nauwelijks nog zinvol in een enkel cijfer laat uitdrukken.

Nu geldt dit laatste bezwaar -zij het dan misschien in mindere mate- in principe voor elke gemeente. Eén van de mogelijkheden dit probleem enigszins te ondervangen is, gemeenten te kiezen, die in bepaalde opzichten 
ven : ekere homogeniteit vertonen. Dit heeft evenwel het bezwär, dat de bij een dergelijke homogenisering toegepaste kriteria niet meer als variabelen in het onderzoek kunnen worden opgenomen. Bovendien was het in een explorerend onderzoek als dit niet goed mogelijk vooraf te bepalen, welke kriteria in verband met de doelstelling de interessantste onderzoekspopulatie zouden opleveren.

Daarom werd afgezien van een homogenisering van het subuniversum naar een of meer sociale, kulturele of economische, voor het anderzoek vermoedelijk relevante, kenmerken van de gemeenten. In plaats daarvan is als tweede selektiekriterium gekozen de geografische homogeniteit van de gemeente, dat wil zeggen, de mate van ruimtelijke concentratie dan wel spreiding van de gemeentebevolking. Dit betekent, dat van de per 31 mei 1960 bestaande 443 gemeenten tussen de 5000 en 200.000 inwoners buiten beschouwing zijn gebleven:

- de 42 zogenaamde heterogeen samengestelde gemeenten valgens de omschrijving van het C.B.S. ${ }^{\text {l) }}$,

- de 197 gemeenten met naast de hoofdwoonkern één of meer woonkernen met 1000 of meer inwoners en/of met woonkernen van minder dan 1000 inwoners, voorzover zich in deze woonkernen tesamen meer dan $30 \%$ van de totale gemeentebevolking bevindt 2 ),

- de 17 gemeenten, waarvan de bevolking voor meer dan 5\% bestaat uit vaste bewoners van inrichtingen, tehuizen, internaten e.d. ${ }^{3}$ j, dit ter vermijding van oneigelijk hoge frekwenties van afwijkend of ziektegedrag,

- de gemeente Tudderen, wegens wisselend Nederlands - Duitse nationaliteit.

De toepassing van deze kriteria resulteerde in een onderzoekspopulatie van 176 gemeenten, welke tesamen $17.7 \%$ van alle Nederlandse gemeenten op 31 mei 1960 en $29 \%$ van de totale Nederlandse bevolking op die datum onvatte. (Bijlage I bevat een naar urbanisatiegraad ingedeelde alfabetische lijst van deze gemeenten)

In tabel 1 wordt de verdeling van zowel het totaal aantal Nederlandse gemeenten als de bij het onderzoek betrokken gemeenten, weergegeven naar de drie urbanisatiehoofdcategorieën volgens de C.B.S.urbanisatiegraadtypologie, te weten de plattelandsgemeenten, de verstedelijkte plattelandsgemeenten en de stedelijke gemeenten. 
Tabel 1: Verdeling van het totaal aantal Nederlandse gemeenten in 1960 en van de 176 onderzoeksgemeenten over de drie urbanisatiegraadcategorieën.

\begin{tabular}{|c|c|c|c|c|}
\hline \multirow{2}{*}{$\begin{array}{l}\text { Urbanisatie- } \\
\text { noofdcategorieën }\end{array}$} & \multicolumn{2}{|c|}{$\begin{array}{l}\text { Totaal aantal Neder- } \\
\text { landse gemeenten }\end{array}$} & \multicolumn{2}{|c|}{ Onderzoeksgemeenten } \\
\hline & abs. & $\%$ & abs. & $\%$ \\
\hline Plattelandsgemeenten & 612 & 61.6 & 44 & 25.0 \\
\hline $\begin{array}{l}\text { Verstedelijkte plattelands- } \\
\text { gemeenten }\end{array}$ & 264 & 26.6 & 62 & 35.2 \\
\hline Stedelijke gemeenten & 117 & 11.7 & 70 & 39.8 \\
\hline Totaal aantal gemeenten & 993 & 100.0 & 176 & 100.0 \\
\hline
\end{tabular}

Hoewel, zoals te verwachten was, vooral de plattelandsgemeenten door de selektiekriteria werden getroffen, zijn toch voldoende (zij het dan niet als representatief te beschouwen) plattelandsgemeenten bij het onderzoek betrokken om de urbanisatiegraad van de gemeente als variabele in het onderzoek te kunnen opnemen en de samenhang tussen gemeentekenmerken en deviante gedragsvormen voor elk van de drie urbanisatiehoofdcategorieën afzonderlijk te kunnen onderzoeken.

2.2 De selektie van de gedragsvariabelen

Zoals gezegd werden in dit onderzoek ter indicering van welzijn en gezondheid van de populatie in principe die vormen van afwijkend en ziektegedrag opgenomen, die op de een of andere wijze objekt van bemoeienis, zorg en daarmee, van registratie zijn.

In feite zijn daarvan opgenomen de gedragsvariabelen waarvoor bruikbare gegevens, dat wil zeggen frekwenties per jaar, per gemeente over de periode 1958 - 1962, beschikbaar waren. Wat betreft dit praktische kriterium verliep de verzameling van de gegevens niet zonder moeite en teleurstellingen. 
Door de verbrokkelde en verzuilde struktuur van de Nederlandse gezondheids- en welzijnszorg vereiste het een soms moeizaam speurwerk te achterhalen waar welke gegevens te vinden waren. Daarbij bleken niet alle gewenste gegevens beschikbaar te zijn, terwijl lang niet alle beschikbare gegevens ook bruikbaar waren, hetzij ondat ze niet kompleet, dat wil zeggen voor alle gemeenten geregistreerd waren, hetzij ondat ze niet vergelijkbaar, dat wil zeggen voor alle gemeenten op dezelfde wijze geregistreerd waren. Hoewel deze problemen voor een deel te maken hadden met de onderzoekperiode 1958-1962 en er sindsdien op het gebied van de registratie verschillende aktiviteiten zijn ondernomen, maakten de opgedane ervaringen wel duidelijk, dat er wat betreft de bruikbaarheid, vergelijkbaarheid en bereikbaarheid van de geregistreerde gegevens nog wel het een en ander te doen viel (Drop, 1973). Blijkens publikaties van het Sociaal Cultureel Planbureau lopen de ontwikkelingen nog steeds achter bij de toenemende behoeften op dit punt (Mootz en Nauta, 1977).

Uiteindelijk bleken voor 36 gedragsvariabelen vergelijkbare geregistreerde gegevens voor alle onderzoeksgemeenten beschikbaar te zijn. ${ }^{4}$ j

De wijze, waarop de in absolute aantallen verzamelde gegevens van deze gedragsvariabelen tot verhoudingscijfers werden omgerekend en de bronnen, waaraan de gegevens werden ontleend, zijn weergegeven in bijlage II. Tabel 2 geeft een statistische beschrijving van de frekwentieverdelingen van deze variabelen met behulp van de spreidingsbreedte, de mediaan, het gemiddelde en de standaarddeviatie.

Deze waarden werden berekend voor de op 'uitbijters' gekorrigeerde frekwentieverdelingen.

Omdat het merendeel van deze verdelingen zich kenmerkte door een, meestal naar rechts verlopende, scheefheid werden ze getransformeerd tot indelingen in klassen met gelijke intervallen, waarbij de extreme waarden in open klassen werden samengenomen. De verdere analyse werd op de gescoorde klasse-indelingen met een voor alle variabelen zoveel mogelijk gelijk aantal $k$ lassen (variërend van 8 tot 10 ) uitgevoerd. 
Tabel 2: Spreiding en centrale tendentie var, 36 gedragsvariabelen

\begin{tabular}{|c|c|c|c|c|}
\hline Gedragsvariabelen & $\begin{array}{l}\text { sprei- } \\
\text { dings- } \\
\text { breedte }\end{array}$ & mediaan & gemiodelde & $\begin{array}{l}\text { standaard- } \\
\text { deviatie }\end{array}$ \\
\hline Niet uitgebrachte stemmen & 6.4 & 3.9 & 4.2 & 1.6 \\
\hline Ongeldige en blanko stemmen & 3.2 & 2.1 & 2.2 & 0.8 \\
\hline Migratiecijfer & 46.9 & 44.2 & 45.3 & 11.6 \\
\hline Emigratiecijfer & 9.42 & 3.15 & 3.50 & 2.23 \\
\hline Echtscheidingscijfer & 2.95 & 0.93 & 1.08 & 0.81 \\
\hline Scheidingen van tafel en bed & 0.70 & 0.18 & 0.22 & 0.20 \\
\hline Jeugdcriminaliteitscijfer & 24.8 & 6.3 & 8.9 & 5.7 \\
\hline Index jeugdcriminaliteit & 31.8 & 20.0 & 20.6 & 8.1 \\
\hline $\begin{array}{l}\text { Onherroepelijke veroordelingen en } \\
\text { seponeringen misdrijven }\end{array}$ & 6.86 & 3.96 & 4.25 & 1.63 \\
\hline Vermogensmisdrijven & 3.13 & 1.71 & 1.82 & 0.78 \\
\hline Agressieve misdrijuen & 5.05 & 1.69 & 1.95 & 1.10 \\
\hline Sexuele misdrijuen & 0.90 & 0.37 & 0.41 & 0.23 \\
\hline Index agressieve misdrijven & 46.7 & 46.1 & 45.4 & 12.0 \\
\hline Zelfmoordcijfer & 1.71 & 0.68 & 0.67 & 0.45 \\
\hline $\begin{array}{l}\text { Alcoholische patienten Medische } \\
\text { Consultatie Bureaus*) }\end{array}$ & 6.72 & 2.48 & 2.94 & 1.85 \\
\hline $\begin{array}{l}\text { Asyleringscoëfficiënt psychiatrische } \\
\text { inrichtingen }\end{array}$ & 14.04 & 6.45 & 7.03 & 3.73 \\
\hline Schizofrenie & 2.76 & 0.79 & 0.96 & 0.83 \\
\hline Affectieve psychosen & 2.78 & 0.68 & 0.89 & 0.86 \\
\hline Neurosen & 2.13 & 0.59 & 0.68 & 0.67 \\
\hline Afgekeurden militaire dienst S5 & 5.99 & 2.21 & 2.42 & 1.41 \\
\hline Afgekeurden militaire dienst & 17.3 & 20.6 & 20.7 & 4.0 \\
\hline Opnamecoëfficiënt A-ziekenhuizen & 7.23 & 7.56 & 7.80 & 1.81 \\
\hline Eesmettelijke ziekten & 33.74 & 12.01 & 14.31 & 13.34 \\
\hline Salmonellosen & 9.73 & 2.74 & 3.73 & 2.97 \\
\hline Dysenterie & 4.81 & 0.57 & 1.21 & 1.46 \\
\hline Roodvonk & 8.95 & 1.10 & 2.01 & 2.36 \\
\hline Hepatitis infectiosa & 14.85 & 2.36 & 4.66 & 5.81 \\
\hline Huwelijksgeboortecijfer & 136.9 & 149.4 & 156.8 & 33.8 \\
\hline Buftenechtelijk geboortecijfer & 5.14 & 1.96 & 2.33 & 1.38 \\
\hline Sterftecijfer & 4.41 & 7.48 & 7.62 & 0.85 \\
\hline Doodgeboortecijfer & 17.3 & 14.8 & 15.6 & 4.1 \\
\hline Zuigelingensterftecijfer & 20.2 & 16.1 & 16.1 & 4.4 \\
\hline Sterfte verkeersongevallen & 3.64 & 1.51 & 1.68 & 0.82 \\
\hline Sterfte overige ongevallen & 2.79 & 1.91 & 1.97 & 0.64 \\
\hline Sterfte kwaadaardige nieuwvormingen & 2.48 & 2.32 & 2.31 & 0.53 \\
\hline Sterfte hartziekten & 2.19 & 1.29 & 1.26 & 0.42 \\
\hline
\end{tabular}

*) $N=149$ 
uiteindelijke centrale registratie van de gegevens brengt dit vrijwel onvermijdelijk met zich mee, dat de kans op fouten, ambiguiteiten, inconsistenties groter geschat moet worden dan bij de gegevens uit de eerste categorie. Gezien de operationele definitie die in het voorafgaande ( $\S 1.3$ ) ten aanzien van afwijkend gedrag werd geformuleerd, werd voor de gedragsvariabelen uitgegaan van hun 'face validity' als indicatoren voor afwijkend en ziektegedrag in de onderzochte gemeenten.

De geldigheid van de gegevens wordt hier opgevat als de proportie door systematische meetfouten veroorzaakte $\because e$. riantie ofwel de systematische afwijking van de gevonden frekwentie ten opzichte van de werkelijke frekwentie ('true incidence') van een bepaald verschijnsel. Nu gat het in dit onderzoek niet om het vaststellen van de feitelijke omvang van het afwijkend en ziektegedrag, mar om het vaststellen en verklaren van de gemeentelijke frekwentieverschillen van het deviante gedrag. Daarom vormt een eventuele afwijking van de gevonden frekwenties ten opzichte van de 'ware' frekwenties alleen een probleem, indien de systematische meetfout niet voor alle gemeenten dezelfde is. In dat geval wordt het namelijk de vraag wat de gemeentelijke frekwentieverschillen betekenen: verschillen in de frekwenties van het afwijkend en ziektegedrag of door de eigenschappen van het 'meetinstrument', veroorzaakte verschilien in 'registratiekansen' van de zich ziek of afwijkend gedragende individuen.

Deze 'registratiekansen' zijn, behalve van de aanwezigheid van de diverse instanties en van hun eerder genoemde eigenschappen mede afhankelijk van de eigenschappen van de individuen die hun kans op behandeling of gedragskorrektie beinvloeden, zoals bijvoorbeeld leeftijd, geslacht, ethnische groep, economische status, opleidingsniveau.

Op basis van een (ruw) geschatte invloed van deze faktoren op de gevonden frekwenties kunnen de gedragsvariabelen

met betrekking tot hun relatieve mate van geldigheid in drie categorieën worden ingedeeld.

Tot de eerste categorie behoren de gedragsvariabelen, waarvoor mag worden aangenomen dat de, door de gemeentelijke overheid op grond van wettelijke bepalingen, geregistreerde gegevens de 'true incidence' van de te meten verschijnselen nagenoeg volledig weergeven en dat ze dus meten wat ze bedoelen te meten. 
De tweede categorie wordt gevormd door de gedragsvariabelen waarvan de gevonden frekwenties vermoedelijk afwijken van de 'ware' frekwenties, maar waarbij een systematische vertekening niet waarschijnlijk is te achten. De derde categorie tenslotte omvat de gedragsvariabelen waarvoor de kans op een systematische vertekening ten opzichte van het gedrag dat zij bedoelen te meten of op systematische verschillen in betekenis tussen de gemeenten relatief hoger moet worden geschat.

Tabel 3: Globale verdeling van de gedragsvariabelen over de onderscheiden betrouwbaarheids- en geldigheidscategorieën.

\begin{tabular}{|c|c|c|}
\hline Geldigheid & $\begin{array}{l}\text { Betrouwbaarheid } \\
\text { le categorie }\end{array}$ & $\begin{array}{l}\text { Betrouwbaarheid } \\
2 e \text { categorie }\end{array}$ \\
\hline $\begin{array}{l}\text { Geldigheid } \\
\text { le categorie }\end{array}$ & $\begin{array}{l}\text { Niet uitgebrachte stemmen } \\
\text { Ongeldige en blanko stemmen } \\
\text { Migratie- en emigratiecijfers } \\
\text { Huwelijksgeboortecijfer } \\
\text { Sterftecijfer } \\
\text { Doodgeboortecijfer } \\
\text { Zuigelingensterfte }\end{array}$ & 2.1 \\
\hline $\begin{array}{l}\text { Geldigheid } \\
2 \text { e categorie }\end{array}$ & 1.2 & $\begin{array}{l}\text { Zelfmoordcijfer } \\
\text { Cijfers van sterfte naar doods- } \\
\text { oorzaken } \\
\text { Besmettelijke ziekten }\end{array}$ \\
\hline $\begin{array}{l}\text { Geidigheid } \\
3 \text { e categorie }\end{array}$ & $\begin{array}{l}\text { Echtscheidingscijfer } \\
\text { Buitenechtelijk geboortecij- } \\
\text { fer }\end{array}$ & $\begin{array}{l}\text { Criminaliteitscijfers } \\
\text { Cijfers alcoholisme } \\
\text { Opnamecoëfficiënt algemene zie- } \\
\text { kenhuizen } \\
\text { Opnamecijfers psychiatrische } \\
\text { inrichtingen } \\
\text { Afkeuringscijfers militaire } \\
\text { dienst }\end{array}$ \\
\hline
\end{tabular}


In tabel 3 wordt aangegeven tot welk van de onderscheiden betrouwbaarheids- en geldigheidscategorieën de gedragsvariabelen vermoedelijk moeten worden gerekend. Anders dan de betrouwbaarheid is de geldigheid, zoals hier opgevat, tot op zekere hoogte te onderzoeken, namelijk voor zover het de invloed van de als gemeentekenmerken meetbare eigenschappen van de diverse 'cijfersproducerende' instanties betreft. Met name de variabelen vermeld in de rechterkolom van tabel 3 zijn vatbaar te achten voor de invloed van de zgn. 'rates producing processes' ( $\$ 1.3$ ).

Om de frekwenties van deze gedragsvariabelen op een dergelijke invloed te onderzoeken werdon gegevens verzameld over de personeelssterkte, behandelingscapaciteit, afstand tot gemeente van een aantal behandelende en 'cijfersproducerende' instanties.

Ook van deze variabelen kenmerkten de frekwentieverdelingen zich door een positieve scheefheid, weshalve ze werden getransformeerd tot indelingen in gelijke intervalsklassen, waarbij de extreme waarden in open klassen werden bijeengevoegd.

Tabel 4 geeft de spreidingsbreedte en centrale tendentie van deze variabelen weer, alsook hun spreiding over de hoofdurbanisatiecategorieën, dit laatste middels de gemiddelde klassescore per urbanisatiecategorie.

Voor deze variabelen werd vervolgens hun relatie met een aantal gedragsvariabelen nagegaan. Wat betreft de criminaliteit heeft Sellin (1951) erop gewezen dat de invloed van de aktiviteiten van de politie op de geregistreerde frekwenties mede bepaald wordt door de mate van 'reportability' (aanwezigheid van een persoonlijk slachtoffer, zichtbaarheid, ernst van de gevolgen van een misdrijf) van de verschillende typen misdrijven. Dit bleek inderdaad uit de samenhangen tussen de politiesterkte van de gemeente en de gemeentelijke criminaliteitscijfers: de jeugdcriminaliteit en de vermogensmisdrijven -misdrijfcategorieën waarin een relatief groter aantal misdrijven met een geringe mate van 'reportability'correleerden aanzienlijk hoger met de politiesterkte (respectievelijk.53 en .56) dan de seksuele misdrijven en de agressieve misdrijven -misdrijfcategorieën met een relatief groter aantal misdrijven met een hoge mate van 'reportability' ( $r$ is respectievelijk .15 en -.01). 


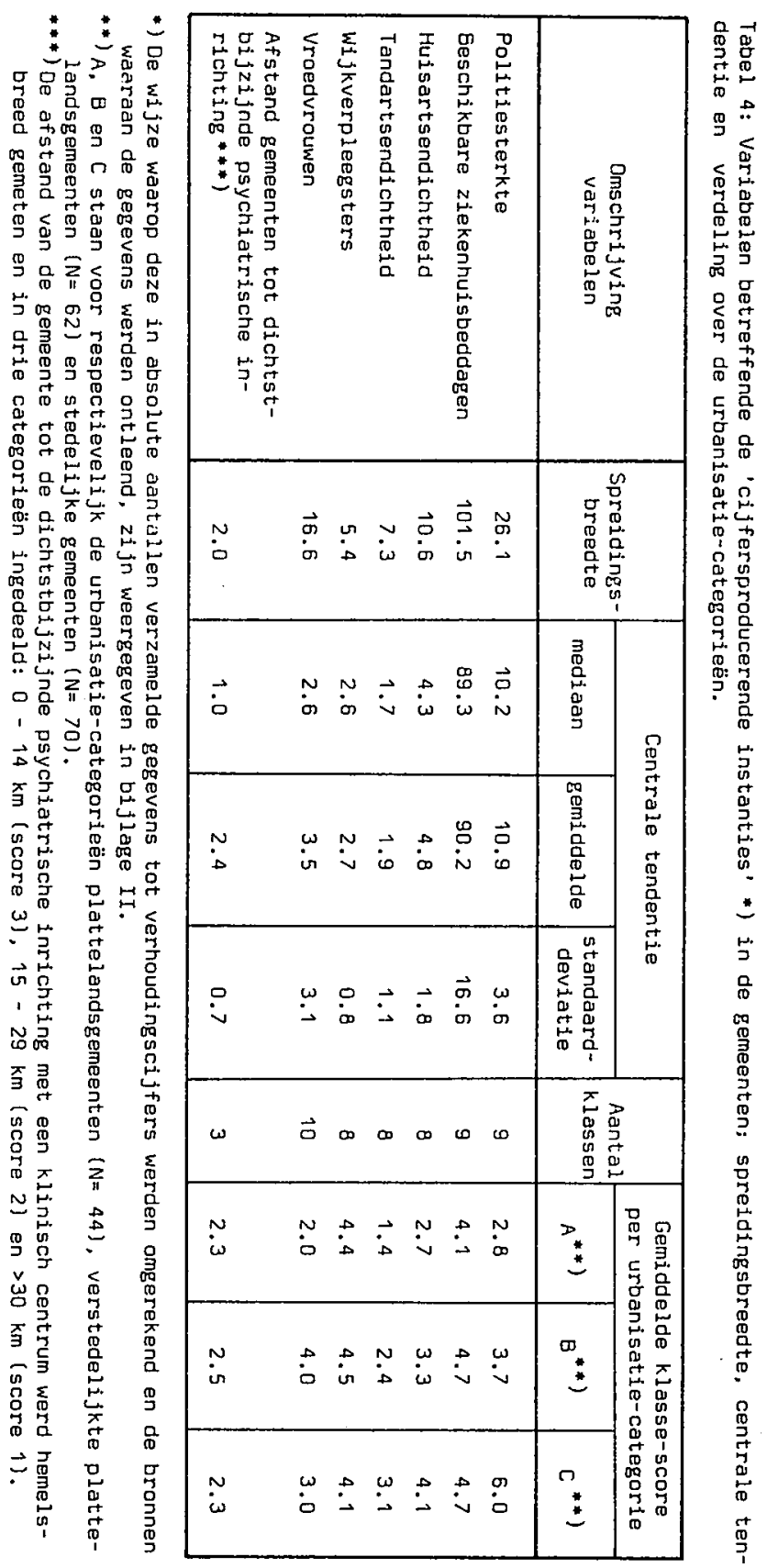


Deze relaties bleken voor een deel te verklaren uit een samenhang van de urbanisatiegraad van de gemeente met zowel de politiesterkte als de criminaliteitsvariabelen: de naar urbanisatiegraad gepartialiseerde correlaties van de jeugdcriminaliteit en vermogensmisdrijven met politiesterkte woren respectievelijk.23 en .24 , die van de seksuele misdrij-. ven en de agressieve misdrijven met politiesterkte beiden -.10 .

Dit neemt niet weg, dat er in ieder geval voor wat betreft de jeugdcriminaliteit en de vermogensmisdrijven, sprake is van een (zwakke) beĩnvloeding van de geregistreerde, ga. meentelijke frekwenties door de eigenschappen van de cijfersproducerende instantie, i.c. de politie.

Deze invloed werd ook nagegaan voor een aantal ziektegedrogvariabelen, allereerst voor die ziektegedragvariabelen waarvoor is aan te nemen dat de geregistreerde frekwenties niet systematisch zullen afwijken van de 'ware' frekwenties (de categorieën 1.1 en 2.2 uit tabel 3 ).

Voor deze variabelen ${ }^{5}$ ) werden de correlaties met de huisartsendichtheid, het aantal wijkverpleegsters, het aantal beschikbare ziekenhuisbeddagen (en voor de doodgeboorten ook met het aantal vroedvrouwen) berekend. Uit deze naar urbanisatiegraad gepartialiseerde correlaties bleek inderdaad niet of nauwelijks sprake te zijn van een samenhang tussen de frekwenties van deze gedragsvariabelen en de aanwezigheid en omvang van de genoemde gezondheidszorgvoorzieningen.

De ziektegedragvariabelen uit categorie 2.3 van tabel 3 , waarvoor de kans op een systematische beĩnvloeding van de geregistreerde frekwenties groter moet worden geacht (opnamecijfers algemene en psychiatrische ziekenhuizen), vertoonden wel een samenhang met de aanwezigheid en omvang van de gemeentelijke 'cijfersproducerende' voorzieningen:

- de multiple correlatiecoëfficiënt van de huisartsendichtheid, de beschikbare ziekenhuisbeddagen en de afstand tot de dichtstbijzijnde psychiatrische inrichting met de opnamecijfers van algemene ziekenhuizen bedroeg . 57 . Met de beschikbare ziekenhuisbeddagen als verreweg de belangrijkste variabele, verklaarden deze drie tesamen dus $33 \%$ van de variantie van de ziekenhuisopnamecijfers;

- de multiple correlatiecoëfficiënt voor de opnamecijfers van psychiatrische inrichtingen met een klinisch centrum 
was .46, dat wil zeggen dat met de drie voorzieningen tesamen $21 \%$ van de variantie van de psychiatrische opnamecijfers werd verklaard.

Volgens deze uitkomsten zijn de beide opnamecijfers niet zonder meer als indikatoren voor de lichamelijke en geestelijke gezondheidstoestand van de gemeentebevolking te beschouwen: voor een deel weerspiegelen de verschillen in opnamefrekwenties tussen de gemeenten ook kwantitatieve verschillen in gemeentelijke medische voorzieningen. Daarmee zal bij de analyse van de samenhangen met de gemeentekenmerken dus rekening moeten worden gehouden.

\subsection{Dimensies in het afwijkend en ziektegedrag}

De vraagstelling van de eerste fase van het onderzoek betrof de relaties tussen de gedragsvariabelen. Blijkens de literatuur is de onderlinge samenhang van de verschillende vormen van afwijkend en ziektegedrag als zodanig niet of nauwelijks onderzocht. Dit neemt niet weg, dat er wel aanwijzingen te vinden waren over mogelijke dimensies in deviant gedrag.

Op individueel niveau betroffen deze aanwijzingen vooral een verschil in objekt van agressieve gedragsreakties. Dit verschil komt bijvoorbeeld tot uiting in het onderscheid tussen extrapunitiviteit -op anderen gerichte agressie- en intropunitiviteit -op zichzelf gerichte agressie. (Rosenzweig, 1945; Rosenzweig, Fleming en Clarke, 1947; Selg en Lischke, 1966). Phillips en Rabinovitch (1958) konstateerden bij de door hen onderzochte psychiatrische patienten verschillende typen van symptomatische gedragingen: 'avoidance of others', 'self-indulgence' en 'turning against others', alsook 'self-deprivation' en 'turning against the self'.

In zijn groepstherapeutische praktijk observeerde Bion (1961) behalve de 'pairing' en de 'dependency' ook de 'fight' en de 'flight' als onderscheiden reaktiepatronen in geval van frustratie, waarbij de groep de groepstaak tracht te ontlopen, door hetzij de taak of elkaar te bevechten, hetzij er voor weg te viuchten. (Bennis en Shephard, 1964].

Uit onderzoek betreffende de politieke participatie bleek politieke vervreemding tot zowel een apathische reaktie (niet gaan stemmen) als een meer agressieve reaktie 
('tegen' stemmen) te kunnen leiden (Thompson en Horton, 1960; McDill en Ridley, 1962).

Met betrekking tot het verschil in richting van de agressie is het interessant, dat Pokorny (1965) na vergelijking van de verschijnselen moord en zelfmoord naar een aantal karakteristieken van daad (tijdstip, plaats e.d.) en dader (leeftijd, geslacht e.d.) vaststelde, dat beide gedragsvormen in op één na (sekse van de dader) alle karakteristieken van elkaar verschilden.

Dit onderscheid in reaktiewijze wordt empirisch en ook theoretisch in verband gebracht met een verschil in socioeco:comische status. Alpert (1952) wijst erop, dat volgens levensverzekeringsgegevens over de periode 1942 - 1949 de kans op zelfmoord van personen uit de hogere sociale milieus tweemaal zo hoog is als voor personen uit de lagere sociale milieus, terwijl in de lagere sociaaleconomische groepen de kans op moord als doodsoorzaak driemaal zo hoog is als in de hogere milieus.

Zigler en Phillips (1960) konstateerden dat de 'most socially effective' van de door hen onderzochte psychiatrische patienten (gemeten aan leeftijd, intelligentie, opleiding, beroep, werkgeschiedenis en burgerlijke staat) vooral symptomen vertoonden, die indikatief zijn voor 'self-deprivation' en 'turning against the self' en dat patienten met symptomen, indikatief voor 'turning against others' en 'avoidance of others' vooral tot het 'less socially effective' deel van de onderzoekspopulatie behoorden.

Henry en Short (1954) ontwikkelden een theorie over de relatie tussen de aan de socioeconomische status gebonden mate van 'external restraint' en de richting van de agressie. De agressie wordt vooral op anderen gericht (moord) in geval van een relatief hoge mate van 'external restraint' (lager sociaaleconomisch milieu) en op zichzelf gericht (zelfmoord) bij een relatief geringe mate van 'external restraint' (hoger sociaaleconomische milieus). Gold (1958) stelde evenwel dat de verklaring voor de milieuverschillen in agressievormen gezocht moet worden in de milieuverschillen in de socialisatie van de agressie, zoals die bijvoorbeeld tot uiting komen in de meer fysieke straffen in de lagere milieus en de meer psychologische straffen in de hogere milieus.

Hier ligt een aanknopingspunt met Merton's typologie van reaktiewijzen op de diskrepantie in de Amerikaanse samenleving tussen kultureel gewaardeerde doeleinden (bijvoorbeeld fi- 
nancieel succes) en sociaal ongelijk verdeelde (wettige) middelen om deze doeleinden te bereiken (Merton, 1961). $\mathrm{Hij}$ onderscheidt als reaktiewijzen ondermeer de 'innovation' -nastreven van de doeleinden met gebruikmaking van onwettige middelen- en het 'ritualism' - na te streven doeleinden worden afgestemd op de beschikbare wettige middelen-, warbij hij op grond van verschillen in de socialisatiepatronen de 'innovation' vooral in de lagere sociale milieus en het 'ritualism' vooral in de 'middle class' verwacht aan te treffen.

In enkele ecologische studies werd ook op boven-individueel niveau een onderscheid tussen op anderen gerichte en op zichzelf gerichte vormen van deviantie vastgesteld. Daarbij bleek evenwel dit onderscheid niet zozeer verband te houden met het socioeconomische niveau als wel met de mate van sociokulturele desintegratie en socioeconomische differentiatie.

Porterfield (1951/52, 1952) konstateerde voor zowel de census tracts van Fort Worth als de staten van Noord Amerika, dat sociokulturele desintegratie, verzwakking van het gedragsregulerend vermogen van het normen- en waardensysteem, gepaard gaan met enerzijds hogere frekwenties van zelfmoord, doch anderzijds lagere cijfers voor moord en criminaliteit. Quinney (1965) vond voor 48 landen een tegengestelde relatie van moord- en zelfmoordcijfers met de urbanisatie- en industrialisatiegraad: een hogere mate van urbanisatie en industrialisatie, en dus van socioeconomische differentiatie, ging samen met hogere zelfmoordcijfers en lagere moordcijfers.

Het onderzoek van Winslow (1970), uitgevoerd op 47 landen leverde vergelijkbare resultaten op: zijn industrialisatieindex correleerde positief met de cijfers voor zelfmoord en neurosen en negatief met de frekwenties voor moord en (geweldadige) politieke incidenten.

Alles bijeen bood de genoemde literatuur voldoende grond om met betrekking tot de verzamelde vormen van afwijkend en ziektegedrag de aanwezigheid van tenminste twee dimensies te veronderstellen, welke zich laten beschrijven in termen van de tegenstellingen tegen anderen gericht, illegitiem en agressief-aktief gedrag versus tegen zichzelf gericht, sociaal getolereerd en passief vluchtgedrag. Om deze dimensies vast te stellen werd voor de 176 gemeenten van het onderzoek een orthogonale componenten-analyse vitgevoerü op 30 gedragsvariabelen. 6) 
Tabel 5: Resultaten van de orthogonale componenten-analyse, voor 176 Nederlandse gemeenten uitgevoerd op 30 gedragsvariabelen: rotatie van drie faktoren *)

\begin{tabular}{|c|c|c|c|}
\hline Variabelen & Faktor I & Faktor II & Faktor III \\
\hline Echtscheidingscijfer & .88 & & \\
\hline Huwelijksgeboortecijfer & -.70 & & \\
\hline Emigratie & .64 & $(.24)$ & \\
\hline Niet uitgebrachte stemmen & .64 & & \\
\hline Migratie & .63 & & \\
\hline Index agressieve misdrijven & -.63 & & $.-.38)$ \\
\hline Buitenechtelijk geboortecijfer & .62 & $\{.31\}$ & \\
\hline Scheidingen tafel en bed & .56 & $(.36)$ & \\
\hline Sterfte verkeersungevallen & -.52 & & $(.20)$ \\
\hline Schizofrenie & .49 & & \\
\hline Neurosen & .44 & & \\
\hline Affektieve psychosen & $(.39)$ & & \\
\hline $\begin{array}{l}\text { Afgekeurden militiare dienst- } \\
\text { plicht }\end{array}$ & -.44 & $(.35)$ & $(.20)$ \\
\hline Vermogensmisdrijven & .44 & .67 & \\
\hline Sexuele misdrijuen & & .68 & \\
\hline Salmonellosen & & .66 & $(.31)$ \\
\hline Agressieve misdrijuen & $(-.27)$ & .64 & $(-.37)$ \\
\hline Ongeldige en blanko stemmen & & .56 & $(-.24)$ \\
\hline $\begin{array}{l}\text { Opnamecoëfficiënt A-zieken- } \\
\text { huizen }\end{array}$ & $(.28)$ & .47 & $(-.27)$ \\
\hline Dysenterie & & .55 & .47 \\
\hline $\begin{array}{l}\text { Afgekeurden militaire dienst- } \\
\text { plicht } 55\end{array}$ & & & .52 \\
\hline Sterfte ongevallen & & & -.49 \\
\hline Roodvonk & $(.30)$ & & .43 \\
\hline Henatitis infectiosa & & & $(.36)$ \\
\hline Doodgeboortecijfer & & & $(.3 E)$ \\
\hline Zelfmoordcijfer & $(.24)$ & $(-.27)$ & \\
\hline Jeugdcriminaliteitscijfer & $(.29)$ & $(.20)$ & $(.31)$ \\
\hline Zuigelingensterftecijfer & & & \\
\hline Sterfte hartziekten & $(.32)$ & $(.33)$ & \\
\hline $\begin{array}{l}\text { Sterfte kwaddaardige nieuw- } \\
\text { vormingen }\end{array}$ & $(.20)$ & $(.24)$ & \\
\hline
\end{tabular}

*) Bijlage III geeft de principale componenten en de geroteerde faktoren van de componenten-analyse volledig weer. 
Als best passende oplossing werd de in tabel 5 weergegeven rotatie (varimax) met drie componenten gekozen (welke in het vervolg in overeenstemming met het heersende spraakgebruik met de term 'faktoren' zullen worden aangeduid). Tesamen verklaarden deze drie geroteerde faktoren $36.2 \%$ van de totale variantie; per afzonderlijke faktor waren deze percentages respectievelijk $18.2 \%, 11.3 \%$ en $6.7 \%$. Dit resultaat is niet onbevredigend, zeker indien rekening wordt gehouden met de wijze waarop de variabelen werden geselekteerd -niet de voorspelde gedragsdimensies, maar de beschikbaarheid van de gegevens vormden in feite het selektiekriterium.

Bij de benoeming van de faktoren is uitgegaan van ladingen van . 40 of hoger. In tabel 5 worden ook, zij het tussen haakjes, lagere faktorladingen tot .20 vermeld. De eerste en tweede faktor vertonen duidelijk overeenstemming met de in de literatuur aangetroffen gedragsdimensies en laten zich goed in termen van de gestelde tegenstellingen beschrijuen.

Voor faktor I geldt, dat nagenoeg alle hoogladende variabelen als legitieme, sociaal getolereerde-zij het in enkele gevallen aan sociale stigmatisering blootstaande (buitenechtelijke geboorte, geestesziekte)- of niet-agressieve gedragswijzen kunnen worden gekarakteriseerd. Uitzonderingen hierop vormen het niet-stemmen en de vermogensmisdrijven. Het niet-stemmen, hoewel destijds formeel strafbaar volgens de kieswet, werd in het algemeen echter nauwelijks als wetsovertreding en zeker niet als misdaad ervaren. De relatief hoge lading (.44) van de vermogensmisdrijven is waarschijnlijk toe te schrijven aan de tamelijk hoge, negatieve correlatie met de eveneens hoogladende index agressieve misdrijven (-.63), welke samenhang $(r=-.50)$ het gevolg is van de wijze waarop deze index is berekend (zie bijlage II). Een aantal van de hoogladende variabelen kan worden gezien als indicatief voor een ontwijkende reaktie: echtscheidingen en scheidingen van tafel en bed, emigratie, niet-stemmen, schizofrenie en neurosen. Met de laatstgenoemde variabelen zijn tevens enkele op zichzelf gerichte reakties gegeven. In dit verband zijn de lage ladingen van de zelfmoord op beide faktoren (.24 op faktor I en -.27 op faktor IIJ wat onverwacht.

Hoewel de richting van de ladingen in overeenstemming is met de opvatting van zelfmoord als op zichzelf gericht ge- 
drag, werd toch op grond van de geciteerde onderzoeksresultaten een hogere correlatie van de zelfmoord met de eerste faktor verwacht. Mogelijk dat hierbij de 'dubbelzinnige' aard (niet op anderen gericht, maar wel agressief) van de zelfmoord een rol speelt.

Door de negatieve ladingen van de sterfte door verkeersongevallen (met motorvoertuigen), blijkens onderzoek van Porterfield (1960) indicatief voor agressief gedrag, en van de index agressieve misdrijven wordt het niet-agressieve karakter van deze faktor aangegeven.

In overeenstemming met de Iiteratuurgegevens vertegenwoordigt faktor II met de hoge, positieve ladingen van de krimiraiiteitsvariabelen duidelijk de illegitieme en tegen anderen gerichte gedragsdimensie. Het agressieve karakter van deze dimensie komt tot uiting in de positief op deze faktor ladende agressieve misdrijven en de ongeldige en blanko stemmen. Laatstgenoemde correlatie houdt tesamen met de hoge positieve lading van de niet-uitgebrachte stemmen op faktor I een ondersteuning in van de hypothese van Thompson en Horton over de beide componenten (apathisch-agressief) van politieke vervreemding. Met de positieve ladingen van de variabelen salmonellosen, dysenterie en opnamecoëfficiënt ziekenhuizen blijkt deze faktor ook door een ziektegedragcomponent te worden gekenmerkt.

Nast hun dominerende karakteristieken werden deze faktoren benoemd als respektievelijk 'vluchtgedrag' en 'agressief gedrag'.

Faktor III was moeilijker te benoemen. De bestudeerde literatuur bood weinig aanknopingspunten.

De faktor kenmerkt zich behalve door negatieve ladingen van de sterfte door ongevallen en de agressieve misdrijven, door positieve ladingen van de variabelen dysenterie, afgekeurden militaire dienstplicht op grond van de 55 kwalificatie en roodvonk.

Daarenboven blijken ook de variabelen salmonellosen, hepatitis infectiosa en doodgeboorte relatief hoog en positief met de faktor te correleren.

Naast een duidelijk niet-agressieve component, lijkt deze dimensie zich vooral te karakteriseren door ziekteverschijnselen, door infektieziekten, die vooral vroeger onder sociaal gedepriveerde omstandigheden voorkwamen. Opvallend is daarbij dat de indicatoren voor de 'moderne' ziekten -sterfte hartziekter, sterfte kwaadaardige nieuwvormingen- niet 
of nauwelijks met deze faktor correleren ( $r$ is respectievelijk -.11 en .05). De hoogladende variabelen wekken de associatie aan onhygiënische leefwijze, aan verpaupering. Gelet op de aard van de ziektegedragvariabelen werd de door faktor III aangegeven dimensie benoemd als 'vatbaarheid'.

Met deze resultaten kon de eerste probleemstelling van dit onderzoek bevestigend worden beantwoord: het blijkt inderdaad mogelijk verschillende dimensies in de op gemeenteniveau gemeten gedragsvormen te onderscheiden.

Omdat in het vervolg van het onderzoek de gevonden gedragsdimensies als de afhankelijke variabelen worden beschouwd, moesten de faktoren tot variabelen worden omgerekend. Bij de eerste bewerking werd voor elke faktor een index berekend middels optelling van de ongewogen klassenscores van de variabelen met een lading $\geqslant .40$ (Drop 1970, 1971). Deze werkwijze heeft echter het bezwaar te leiden tot onbedoelde correlaties tussen de faktoren (Stouthard, 1973). Daarom werden de faktorscores opnieuw berekend volgens de methode van de kleinste kwadraten-schatters naar de definitie van Horst, door McDonald en Burr (1967) beschreven als Method I. Hiermee werd de statistische onafhankelijkheid van de faktoren bewerkstelligd. (Wat betreft de rangordening van de gemeenten per dimensie geven beide procedures overigens in hoge mate overeenstemmende resultaten te zien: voor vluchtgedrag, agressief gedrag en vatbaarheid zijn de correlaties tussen faktorindex en faktorscores respectievelijk.96,.94 en .80).

De gemiddelde score en de spreiding zijn voor elk van de faktoren respectievelijk 500 en 100; de spreidingsbreedte voor vluchtgedrag 270 - 719, voor agressief gedrag 328 780 en voor vatbaarheid 265 - 784. De scores van de gemeenten op elk van de drie faktoren zijn, ingedeeld in kwartielen, weergegeven in bijlage IV.

De onderscheiden gedragsdimensies blijken geen voor het platteland of de stad typerende vormen van deviant gedrag weer te geven: de faktor vluchtgedrag en de faktor agressief gedrag correleren beide positief met de urbanisatiegraad ( $r$ is respectievelijk.62 en .43), de faktor vatbaarheid vertoont geen samenhang met de urbanisatiegraad ( $r$ is -.02 J.

Met deze gedragsdimensies kon de probleemstelling over de relatie tussen gemeentekenmerken en de frekwenties van geregistreerd afwijkend en ziektegedrag worden toegespitst 
op de vraag of en in hoeverre verschillen tussen de gemeenten in scores op de gedragsdimensies gepaard gaan met verschillen in de sociale, economische, culturele kenmerken van de gemeenten. Met deze bijstelling van de onderzoeksvraag ging het dus niet meer om de relatie gemeentekenmerken en frekwenties van afwijkend en ziektegedrag, maar om de samenhang van gemeentekenmerken met typen van deviant gedrag. 
3.1 Het verkennend karakter van het onderzoek

Het onderzoek werd ondernomen vanuit een tamelijk globale vooronderstelling over de invlced van eigenschappen van de populatie, habitat en voorzieningen van de gemeenten op het welzijn en de gezondheid van die populatie.

Daarmee was dit onderzoek in eerste instantie te typeren als een verkenning zowel van de aard van deze invloed als van de daarbij betrokken omgevingskenmerken.

Het explorerend karakter van het onderzoek had uiteraard gevolgen voor de selektie van de variabelen en de verzameling van de gegevens. In principe is met een verkennende opzet van een onderzoek bij de keuze van de variabelen een grote mate van willekeur gegeven.

Een manier om dit probleem van selektiewillekeur op te lossen bestaat uit de toepassing van de zgn. 'sleepnetmethode'. Daarmee wordt bedoeld de verzameling van zoveel mogelijk variabelen, in de hoop dat op die wijze ook de variabelen worden 'gevangen', die voor de vraagstelling van belang zullen blijken te zijn.

Deze werkwijze, door verschillende onderzoekers om verschillende redenen toegepast -Jonassen en Peres (1960), Schmid en Tagashira (1964), Hadden en Borgatta (1965), Sweetser (1965), Janson (1968), Munson (1968)- met al dan niet de beschikbaarheid van de gegevens als grensstellend kriterium (Moser en Scott, 1961) wordt door Rogers en Messinger (1967) tot principieel uitgangspunt verheven. Zich baserend op het onloochenbare feit, dat de menselijke omgeving op zich, alsook het netwerk van relaties van de mens met zijn omgeving zeer complexe gehelen vormen, bepleiten zij ten aanzien van de relatie omgeving-gezondheid een holistische benadering. Daarmee bedoelen zij, dat de mens en zijn omgeving als een interacterend geheel moeten worden beschouwd, zodanig dat tevoren geen onderscheid gemaakt wordt tussen afhankelijke en onafhankelijke variabelen, noch het aantal te onderzoeken aspekten a priori wordt beperkt. Met als doel de bruikbaarheid te onderzoeken van de faktoranalyse als techniek ter identificatie van variabelen die behoren tot 'associational systems' in een holistische benadering van de relatie omgeving-gezondheid, voegden de auteurs de daad bij het woord en verzamelden voor 48 staten van Noord-Amerika gegevens over het jaar 1960 voor 372 variabelen. 
Op grond van onderlinge correlaties en vervolgens een enigszins willekeurige selektie, waarbij de auteurs voorkeur vertoonden voor demografische variabelen, die duidelijk met verschillende sterftecijfers correleerden, werden deze 372 variabelen tot 87 gereduceerd. De resultaten van de daarop uitgevoerde faktoranalyse geven vooral het bestaan van een 'survival-centered associational system' aan, wat niet zo verwonderlijk is gezien de 'bias' in de (toch nog) toegepaste selektie van de variabelen: 30 van de 87 variabelen betreffen sterftecijfers en de verwachte levensduur:

Rogers en Messinger onderkennen deze 'bias' wel, maar vinden deze niet zo bezwaarlijk, ondat in een cumulatieve serie van dergelijke analyses steeds nieuwe variabelen kunnen worden toegevoegd, zodat het totale proces uiteindelijk een toenemend dichte benadering van een holistisch model van de relaties van de mens met zijn omgeving zal opleveren. Afgezien van de vraag of deze 'de-werkelijkheid-spreektvoor-zichzelf' opvatting uiteindelijk tot bruikbare resultaten zal leiden, is de hier aanbevolen procedure voor dit onderzoek, waarin trouwens wel degelijk onderscheid wordt gemaakt tussen onafhankelijke (gemeentekenmerken) en afhankelijke variabelen (ziekte- en afwijkend gedrag), duidelijk te omslachtig en tijdrovend. Het gebrek aan enig kriterium maakt het bovendien moeilijk te bepalen bij welk resultaat van deze empirische werkwijze de dichtst mogelijke 'benadering van het holistische model' is bereikt. Daarnaast levert deze methode geen ordenend principe op, aan de hand waarvan de nieuw toe te voegen variabelen kunnen worden gekozen. Deze selektie blijft daarmee tot het eind van de procedure een kwestie van willekeur, die alleen wordt beperkt door het aantal reeds verwerkte variabelen.

Dit voorbeeld van een tot principe verheven selektiewillekeur is dus niet nagevolgd.

Hoewel vanwege het exploratieve karakter van het onderzoek een empirische werkwijze en een zekere mate van willekeur bij de selektie van de variabelen niet geheel waren te vermijden, is er toch naar gestreefd het 'sleepnet', om bij de eerder gebruikte terminologie te blijven, verstandig uit te werpen en deze willekeur zoveel mogelijk te beperken.

Behalve op overwegingen van het gezond verstand, berustte de keuze van de gemeentekenmerken, die in verband met de vraagstelling van belang konden worden geacht, op aanwijzingen die daarover in de literatuur te vinden waren. 
Gezien de vraagstelling en het analyseniveau van het onderzoek kon wit verschillende bronnen worden geput:

- literatuur over theorie en onderzoek van afwijkend en ziektegedrag.

- literatuur over ecologisch onderzoek naar het voorkomen, de spreiding en de correlaties van frekwenties van afwijkend en ziektegedrag.

Alles bijeen bleek dit een dusdanig mer à boire aan literatuur te vormen, dat zowel bij de bestudering als bij de rapportage ervan, een streven naar volledigheid als een tamelijk futiele bezigheid moest worden beschouwd.

In de volgende paragrafen worden in vogelvlucht de belangrijkste theoretische benaderingen en resultaten van onderzoek over oorzaken en spreiding van afwijkend en ziektegedrag aangegeven en samengevat.

3.2 Samenvatting van literatuur over theorie en onderzoek naar aard en oorzaken van afwijkend en ziektegedrag

De belangrijkste conclusie die zich opdringt bij de bestudering van de sociologische deviantieliteratuur is, dat met het verlaten van de simpele verklaring van afwijkend gedrag als 'slecht gedrag van slechte mensen', de zaak er niet eenvoudiger op is geworden.

Hoewel sindsdien het inzicht in het afwijkend gedrag aanzienlijk is verbreed en verdiept, heeft deze kennis een sterk verbrokkeld, om niet te zeggen chaotisch, karakter.

Er is sprake van een moeilijk tot een samenhangend geheel

te comprimeren veelheid aan benaderingen, gezichtspunten en begrippen over van belang geachte aspekten en faktoren, die afwisselend binnen een individuele, situationele of strukturele context worden geplatst.

Een groot probleem daarbij is, dat deze benaderingen die de bouwstenen voor een geĩntegreerde theorie zouden kunnen vormen, niet of nauwelijks op een toetsbare, middels empirisch onderzoek te verifiëren wijze zijn geformuleerd -in dit opzicht kan veelal eerder van beschouwingen en diagnosen van de samenleving dan van theorieën over het afwijkend gedrag worden gesproken (Winslow, 1970).

Het deviantie-onderzoek, met een in vergelijking exponentiële omvang - getuige bijvoorbeeld de overzichtsartikelen van Murphy (1961): sociale verandering en geestelijke gezondheid, 90 titels; Martin (1967): omgevingscondities en gezondheid, 
80 titels; Senay en Redlich (1968): kulturele en sociale faktoren en neurosen, psychosomatische ziekten, 56 titels; Devries (1968): zelfmoord, 353 titels; Petras en Curtis (1968): socio-economische status en geestesziekte, 350 titels; Rushing (1969): zelfmoord, 82 titels; Edwards. (1973): jeugddelinquentie, 59 titels- weerspiegelt deze theoretische stand van zaken. De grote diversiteit in vraagstelling, onderzoeksopzet, -populatie, en -methode bemoeilijkt de evaluatie en daarmee de vergelijking van de resultaten.

Daarbij komt dat een groot deel van het onderzoek is uitgevoerd op steekproeven uit naar tijd en plaats bepaalde populaties van individuen, reden warom vergelijking van de resultaten ook geen generaliseerbaar geldige kennis kan opleveren.

Onderzoek, uitgevoerd op de in particuliere termen (plaats en tijd) omschreven populaties van individuen, leidt immers alleen tot uitspraken met een voor die populatie beperkte geldigheid. Al naar gelang de resultaten van herhaald onderzoek op verschillende populaties overeenstemmen of van elkaar verschillen, kan alleen worden geconstateerd dat de onderzochte populaties van individuen identieke dan wel verschillende parameters bezitten (Willer, 1967).

De thema's die zich laten onderscheiden hebben dan ook veel meer van gemeenschappelijke visies op aard en oorzaken van afwijkend gedrag dan van toetsbare l) of getoetste theorieën. De verschillende benaderingen en het daaraan gekoppelde onderzoek van de deviante gedragsvormen die door de samenleving als problematisch zouden worden ervaren, zoals kriminaliteit,zelfmoord, alcoholisme, geestesziekte, worden in verschiliende handboeken weergegeven (Merton en Nisbet, 1961; Dynes et al., 1964; Cohen, 1966; Clinard, 1968; Winslow, 1970; Rock and McIntosh, 1974).

Met eigenlijk alleen de benadering die vitgaat van de 'maatschappelijke reaktie' en van de 'etikettering' als een duidelijke, principiële uitzondering (Lemert, 1951; Kitsuse, 1962; Becker, 1963; Scheff, 1966; Turk, 1966; Schur, 1969; Gove, 1970; Philipsen, 1970; Rushing, 1971) wordt afwijkend gedrag gemeenlijk -meer of minder expliciet-beschouwd als een reaktie op 'strains', 'stress' of frustratie, als falend 'coping behavior'.

In deze betekenis worden frekwenties en spreiding van deviant gedrag veelal opgevat als indicatoren voor mate en spreiding van matschappelijk welzijn.

De bronnen van deze 'pressures for deviance' worden gezocht in de eigenschappen van het sociale systeem en/of de omge- 
ving, die noodzaken tot het zoeken naar oplossingen en 'modes of adaption' en daarmee voor bepaalde categorieën individuen of maatschappelijke groeperingen het risiko van falend (sociaal niet-geaccepteerd) 'coping behavior' inhouden (Howard en Scott, 1965).

Als zodanige eigenschappen en omgevingskondities worden in de literatuur genoemd:

- sociale disorganisatie en sociokulturele desintegratie, veel gebruikte, maar weinig nauwkeurig omschreven begrippen, warronder ook faktoren als sociale verandering, industrialisatie, economische crises, toenemende arbeidsverdeling, urbanisatie, mobiliteit en bevolkingsgroei worden begrepen;

- discrepantie tussen doeleinden en middelen, relatieve deprivatie, waarbij vooral aandacht wordt besteed aan de beschikbaarheid van de middelen ('resources') om de problemen op een legitieme, sociaal-geaccepteerde wijze op te lossen of de 'strains' te verwerken. Betreffende de 'coping resources' (maatschappelijke weerbaarheid, 'adaptive adequacy') worden verschillende aspekten onderscheiden: sociale macht (inkomen, opleiding, sociale status), aanwezigheid en toegankelijkheid van hulpverlenende instanties, leeftijd, participatie in hulpgevende en ondersteunende netwerken van persoonlijke of communale relaties;

- normatieve struktuur, normen en waardenpatroon als doelstellend en middelbepalend referentiekader voor het handelen. In deze benadering wordt de differentiële spreiding van deviant gedrag in verband gebracht met faktoren als de homogeniteit of heterogeniteit van het normen- en waardenpatroon, de door milieu of ethnische afkomst bepaalde verschillen in waardenoriëntatie, de aanwezigheid van (deviante) subkulturen, de dominantie van bepaalde kulturele tradities en waarden, die de keuze van de gedragsreaktie konditioneren (geweldtraditie, 'frontier culture', godsdienst, 'middle class' ritualism);

- mechanismen van het sociale beheersingssysteem, zoals de - veelal sociaal gekonditioneerde- mogelijkheden tot de keuze van alternatieve, geaccepteerde of althans getolereerde vormen van 'coping behavior' (bijvoorbeeld de patientenrol); de beschikbaarheid en toegankelijkheid van legitieme middelen tot verwerking van 'stress', tot ontspanning. Hieronder kan ook worden begrepen de eerder aangeduide benadering waarin wordt uitgegaan van de selektieve toepassing van sankties, gesteld op 'vreemd' en 'ongewenst' gedrag, van de maatschappelijke reaktie waardoor het gedrag als 'afwijkend' bekend 
en gedefinieerd wordt en in samenhang daarmee de verschillen in normen, aktiviteiten en spreiding van behandelende $?$ en korrigerende instanties;

- omgevingskondities, waronder met name verschillen tussen stad en platteland, mar ook bewonings- en bevolkingsdichtheid, lokatie en type van woningen (flats), hardheid van het water e.d..

Hiermee zijn de belangrijkste benaderingen en hypothesen gegeven waaronder wat betreft hun relevantie voor de verklaring van aard en oorzaken van afwijkend gedrag een zekere mate van consensus bestaat.

In deze samenvatting is afgezien van een inventarisatie van konkrete variabelen die in de hier ondernomen studie zouden kunnen worden opgenomen.

Naast de diversiteit aan theoretische benaderingen kenmerkt het sociologisch deviantie-onderzoek zich namelijk ook door een verscheidenheid aan operationele omschrijvingen van de gehanteerde begrippen. Dit komt tot uiting in een veelheid aan indicatoren, waarbij één en hetzelfde begrip in de diverse onderzoekingen met verschillende variabelen wordt gemeten en omgekeerd één en dezelfde variabele dient ter indicering van verschillende begrippen.

Het veelgebruikte begrip 'socio-economische status' vormt daarvan een duidelijk voorbeeld. Enerzijds wordt dit begrip op uiteenlopende wijze geĨndiceerd: inkomen, opleiding, beroepsprestige, huishuur, huis-, auto- of telefoonbezit, waarde, kwaliteit van de woning, ras of ethnische afkomst, waarbij het de vraag is of deze gegevens steeds op dezelfde sociale categorie betrekking hebben. Anderzijds geldt de sacio-economische status, hoe dan ook gemeten, in relatie tot de spreiding van deviant gedrag, als indicatie van de mate van 'external restraint' ('social control', matschappelijke reaktie), van verschillen in socialisatie en in normen- en waardenoriëntatie (verschillen in kultuurpatroon), van de mate van sociale, economische en politieke deprivatie, van gerealiseerde of mislukte matschappelijke ambities, van de mate van sociale participatie, van de mate van sociale macht en maatschappelijke weerbaarheid, de beschikbaarheid van legitieme middelen voor de realisering van kultureel bepaalde doeleinden. 
3.3 Samenvatting van literatuur over ecologisch onderzoek naar voorkomen en spreiding van afwijkend en ziektegedrag

Ook het ecologisch onderzoek naar afwijkend en ziektegedrag kenmerkt zich door een grote verscheidenheid aan zienswijzen en benaderingen, warbij bovendien het niveau van analyse varieert ('census tracts', stadswijken, gemeenten, provincies). De meeste studies hebben echter met elkaar gemeen, dat ze gebruik maken van, vaak voor andere doeleinden, geregistreerde gegevens voor de operationalisering van hun variabelen. Hoewel de selektiekriteria lang niet altijd expliciet worden vermeld, ontlenen de ecologische studies hun variabelen, (alsook hun hypothesen], veelal aan de gangbare theorieën en opvattingen over de oorzaken van afwijkend gedrag.

Wat daarbij opvalt is het kennelijke gemak, waarin in een aantal van deze studies op individueeel niveau geformuleerde veronderstellingen en interpretaties naar een boven-individueel niveau worden getransponeerd. Hierin manifesteert zich wat wagner (1964) de 'fallacy of displaced scope' heeft genoemd. Hij bedoelt daarmee de zowel bij de struktureel-funktionalisten als bij de symbolisch-interaktionalisten aangetroffen assumptie, dat op macrosociologisch niveau ontwikkelde theorieën zonder meer toepasbaar zijn op micro-sociologisch niveau en vice versa. De Graaf (1973) wijst erop dat deze assumptie van de toepasbaarheid van een theorie op het gehele micro-macro sociologische continuüm de veronderstelling impliceert van een consistentie van relaties tussen variabelen voor eenheden van verschillende niveaus. Daarnaast werkt deze implicite assumptie ook de 'ecological fallacy' in de hand.

Niet alleen worden de in deze studies op individueel niveau gevonden of gepostuleerde relaties tussen deviant gedrag en. faktoren als sociale isolatie, sociale participatie, rolconflict, status inconsistentie, normen- en waardenincongruentie, gefrustreerde ambities vertaald in te verwachten samenhangen tussen frekwenties van deviant gedrag en kenmerken van 'census tracts', gemeenten etc., maar ook worden, met name in de beschrijvende studies, de ecologische variabelen zonder al te uitvoerige theoretische reflexie meer of minder expliciet gekozen en geoperationaliseerd als vertalingen van relevant geachte kenmerken van individuen. Een klassiek voorbeeld daarvan is de interpretatie van Faris en Dunham (1939) van de door hen geconstateerde disproportioneel hoge frekwenties van gehospitaliseerde schizofrene patienten in de arme centrale en transitie buurten van Chicago. Zij verklaarden deze hoge frekwenties als te- 
weeg gebracht door de response van bepaalde buurtbewoners op hun sociale isolatie, die het gevolg is van de, voor deze buurten kenmerkende, heterogeniteit en mobiliteit van de bevolking.

overigens heeft Dunham $(1964,1968)$, onder andere naar aanleiding van onderzoek waaruit bleek dat de relatief hoge concentratie van schizofrene patienten in dergelijke buurten veeleer het gevolg is van de aantrekkingskracht van deze buurten voor reeds zieke en sociaal-geisoleerde personen (Gerard en Houston, 1953; Hare, 1956), deze 'sociale isolatie' verklaring later herroepen. Hij kritiseert deze verklaring als een sociaalpsychologische interpretatie achteraf en stelt dat de op het niveau van sociale systemen gevonden ecologische correlaties ook op het niveau van sociale systemen, bijvoorbeeld in termen van sociale selektieprocessen, moeten worden verklaard.

De al dan niet verhulde analogie-redenering, deze 'displacement of scope', valt overigens niet alleen te constateren voor de vertaling van kenmerken van individuen in eigenschappen van bovenindividuele eenheden. Bij vergelijking van met name beschrijvende, 'census tracts' en gemeentenonderzoekingen blijkt een grote overeenkomst in de geselekteerde variabelen, zonder dat ooit de vraag aan de orde werd gesteld of de betekenis van de variabelen voor beide analyseniveaus wel dezelfde is. Datzelfde geldt voor de vraag of voor identieke variabelen bij meting op verschillend boven-individueel niveau ook identieke samenhangen met elkaar of met de frekwenties van afwijkend en ziektegedrag mogen worden verwacht.

Hoewel de conclusie tentatief is (de speurtocht door de literatuur leverde geen voorbeelden op van specifiek op deze vraag gericht onderzoekJ, lijkt bij vergelijking van de resultaten van 'census tracts' onderzoek en van gemeentenonderzoekingen deze vraag eerder ontkennend dan bevestigend te moeten worden beantwoord: de mechanismen die de differentiatie van de stadsbuurten bepalen lijken te verschillen van die, welke de verschillen tussen gemeenten bewerkstelligen. Deze uitspraak laat zich illustreren aan de hand van de relaties tussen de variabelen bevolkingsdichtheid, 'overcrowding', geboortecijfer en socio-economische status (opleidings- en inkomensniveau). Hoewel blijkens de resultaten van de 'social area analysis' (Shevky en Williams, 1949; Shevky en Bell, 1955; Abu-Lughod, 1969 ) aan de ecologische struktuur van de stad verschillende dimensies zijn te onderscheiden, is en blijft de socio- 
economische status een belangrijke scheidslijn waarlangs eigenschappen van de stedelijke populatie, habitat en voorzieningen zich struktureren.

De resultaten van de 'census tracts' studies zijn in hoge mate consistent wat betreft de identificatie van gedepriveerde buurten, waar een relatief laag opleidings- en inkomensniveau van de bewoners gepaard gat met naar verhouding hogere geboortecijfers en gratere bevolkingsdichtheid en 'overcrowding'.

Zij het wat minder pregnant, geven de uitkomsten van op gemeenteniveau uitgevoerde studies wat de interrelaties van deze variabelen betreft een ander patroon te zien.

Het inwonertal en daarmee de bevolkingsdichtheid van de gemeente blijken bepalend voor de noodzaak dan wel mogelijkheid tot de aanwezigheid van velerlei voorzieningen, tot de vestiging van zo niet industriële, dan toch handels- of dienstverlenende bedrijven en organisaties, tot het ondernemen van sociale en kulturele aktiviteiten. Deze eigenschappen van habitat en voorzieningen gaan, behalve met stedelijke karakteristieken zoals bijvoorbeeld relatief lage geboortecijfers (en mogelijk ook geringere bewoningsdichtheid) gepaard met een relatief hoog opleidings- en inkomensniveau van de gemeentebevolking: de in verschillende studies geĩdentificeerde urbanisatiefaktor karakteriseert zich veelal door een welstandscomponent, terwijl de bevolkingsgroeifaktor vaak wordt gekenmerkt door positieve ladingen van opleidings- en inkomensvariabelen (Moser en Scott, 1961; Hadden en Borgatta, 1965; Jonassen en Peres, 1960; Munson, 1968).

Deze tegenstelling in de relatie van bevolkingsdichtheid en 'overcrowding' met opleidings- en inkomensniveau -negatief op het niveau van stadsbuurten, positief op het niveau van gemeenten- is natuurlijk niet zonder gevolgen voor de samenhangen met de frekwentie van afwijkend en ziektegedrag. Waar op het niveau van stadsbuurten de frekwenties van verschillende deviante gedragsvormen naast positieve correlaties met bevolkingsdichtheid en 'overcrowding', evenals op het niveau van individuen, een negatieve samenhang met opleidings- en inkomensniveau vertonen, daar zou op het niveau van gemeenten (en dus ook in dit onderzoek) voor verschillende gedragsvariabelen behalve een mogelijk positieve relatie met inwonertal en bevolkingsdichtheid, ook een positieve correlatie met socio-economische status-indices kunnen worden verwacht, terwijl via de tevens tegengesteld variërende geboortecijfers sprake kan zijn 
van een negatieve samenhang met de variabele 'overcrowding' . Behalve de beschikbaarheid van de gegevens zou de impliciete analogie-redenering van het individuele naar het bovenindividuele niveau een reden kunnen zijn waarom in de besproken studies bij de gekozen variabelen de populatiekenmerken overheersen.

Op enkele uitzonderingen na, waarin uitdrukkelijk zowel wat betreft de hypothesen als wat betreft de operationalisering van de variabelen macro-sociale verschijnselen en samenhangen aan de orde worden gesteld, kenmerken de besproken ecologische studies zich door een kwantitatieve dominantie van analytische ten opzichte van globale variabelen.

Niet alleen de kenmerken van de populatie, maar ook de voorzieningen (door de bewoners van de habitat ondernomen aktiviteitenl worden vaak geoperationaliseerd met behulp van gesommeerde eigenschappen van individuen - zo worden bijvoorbeeld faktoren als werkgelegenheid, mobiliteit, sociokulturele heterogeniteit, urbanisatie, industrialisatie, secularisatie gemeten met variabelen als \% werkelozen, \% migranten, \% niet-blanken, \% agrariërs, \% in industrie werkzame beroepsbevolking, \% onkerkelijken.

Hoewel in sommige oudere studies (Thorndike, 1939, 1940; Hyde en Kingsley, 1944 a) reeds gegevens zijn opgenomen over rekreaatieve voorzieningen, publieke werken, musea, bibliotheken, onderwijs, kwaliteit van de woningen, vestigingen van winkels en bedrijven, e.d., worden in verschillende onderzoekingen ook de globale variabelen gekonstrueerd met behulp van populatiekenmerken, zoals bijvoorbeeld de 'common culture index' en de 'index of relative opportunities' van Linsky (1970). Wat de kenmerken van de habitat betreft concentreert de keuze van de variabelen zich op de gemeentegrootte (aantal inwoners), bevolkingsdichtheid en bevolkingsgroei (Hyde en Kingsley, 1944 b; Gordon en Gordon, 1960; Wechsler, 1961/62; Schmitt, 1957, 1966; Galle et al., 1972). In sommige studies worden ook gegevens over landgebruik, wijze en dichtheid van bebouwing of ook luchtvervuiling en calciumgehalte van het drinkwater opgenomen (Gardner et al., 1969).

Evenals in de samenvatting over de theoretische benaderingen van afwijkend en ziektegedrag kan ook voor het ecologisch deviantie-onderzoek het probleem van de meervoudige betekenis van zowel begrippen als indicatoren worden gesignaleerd. Dit kan als volgt worden geiliustreerd. Dok in het ecologisch deviantie-onderzoek wordt relatief veel aandacht besteed aan de mogelijke effekten van de mate van 
sociale of morele integratie van de 'community'.

Daarbij komt, evenals in de eerder besproken theoretische benaderingen, de zo niet meervoudige dan toch ruime betekenis van het integratie-begrip tot uiting in de wisselende accenten op de mate van stabiliteit van de sociale relaties (sociale cohesiel, de mate van overeenstemming van belangen, normen en waarden (sociokulturele consensus) en de mate van gedragsregulerend vermogen van het normatieve systeem ('social control').

Behalve dat voor deze verschillende integratie-aspekten vaak dezelfde indicatoren worden gebruikt -mobiliteit, bevolkingsgroei, heterogeniteit of diversiteit (godsdienstig, politiek, sociaal, economisch, ethnisch)- worden deze indicatoren veelal gemeten met gegevens, zoals bijvoorbeeld \% door eigenaar bewoonde woningen, waarde van eigen huizen en van huurhuizen, $\%$ niet-blanken, \% beroepsbevoking met 'white collar' beroepen, inkomensverschillen, \% werkende gehuwde vrouwen, die binnen een andere theoretische context dienen te indicering van een socioeconomische deprivatie, een doeleinden - middelen discrepantie dan wel de socioeconomische status van de gemeente.

Deze meerduidigheid van begrippen, indicatoren en operationalisaties weerspiegelt enerzijds de stand van zaken van de theorie over het afwijkend gedrag, maar getuigt anderzijds van de multikonditionaliteit van de differentiële spreiding van afwijkend gedrag. In dit opzicht is er sprake van een zekere consensus, niet alleen over de veelheid, mar ook over de aard van de omgevingsaspekten, die op de spreiding van afwijkend en ziektegedrag van invloed zouden kunnen zijn.

3.4 Kenmerken van gemeenten en hun onderlinge samenhangen

De literatuurstudie had verschillende, nogal uiteenlopende gevolgen voor de verdere ontwikkeling van het onderzoek. In de eerste plaats was het literatuuronderzoek overeenkomstig de bedoeling van invloed op de selektie van de variabelen.

Ondanks de veelheid aan variabelen en de variërende theoretische zienswijze van waaruit de variabelen worden geduid en hun samenhangen worden geinterpreteerd valt er in de bestudeerde literatuur een zekere mate van overeenstemming te constateren over de omgevingsaspekten, die bij de spreiding van afwijkend gedrag een rol zouden kunnen spelen. Deze consensus betreft in ieder geval de globale omgevingsaspekten die verondersteld worden verband te houden met de 
spreiding van deviant gedrag. Deze aspekten kunnen als volgt worden omschreven:

a. Fysiek-morfologische omgevingskenmerken als stedelijkheid, landgebruik, dichtheid van de bebouwing, dichtheid en concentratie van de bevolking, kwantiteit en kwaliteit van de woningen, type woningen.

b. Socioeconomische faktoren als welstandsniveau, relatieve deprivatie, inkomensverdeling, socioeconomische weerbaarheid.

c. Eigenschappen van de economische struktuur, zoals eenzijdigheid van de economische aktiviteiten, conjuncturele kwetsbaarheid van bedrijfstakken of -klassen, eenzijdigheid van de beroepenstruktuur, industrialisatie, situatie op de arbeidsmarkt.

d. Eigenschappen van de sociokulturele omgeving zoals autochtoniteit, mobiliteit, omvang en tempo bevolkingsgroei, herkomst van de bevolking, sociale, godsdienstige, politieke diversiteit van de bevolking ('common culture'), dominantie van bepaalde normen- en waardenpatronen (godsdienst), secularisering.

e. Demografische faktoren als leeftijdsopbouw van de bevolking, vergrijzing van de bevolking, sexe-ratio, verdeling van de bevolking naar burgerlijke staat.

$f$. Aanwezigheid van voorzieningen op het gebied van medischmaatschappelijke zorg, onderwijs, sport, rekreatie, kultuur.

Deze omgevingsaspekten werden vertaald in gemeentekenmerken, waarvoor vervolgens werd nagegaan met welke gegevens ze te meten zouden zijn. Evenals bij de gedragsvariabelen speelde in deze fase van de selektie, naast de aanwijzingen in de literatuur, vooral de beschikbaarheid van bruikbare, dat wil zeggen voor alle gemeenten verzamelde en vergelijkbare gegevens een belangrijke rol.

Voor een aantal gemeentekenmerken bleken er geen, of niet voor alle gemeenten dezelfde, gegevens beschikbaar te zijn. Bovendien was het lang niet altijd mogelijk de kenmerken als eigenschappen van de gemeente zelf, dat wil zeggen als globale variabelen, te meten, maar moest gebruik worden gemaakt van geaggregeerde eigenschappen van individuen, dat wil zeggen van analytische variabelen.

De verzameling en bewerking van de bruikbare gegevens resulteerden uiteindelijk in een totaalbestand van 62 enkelvoudige en 5 samengestelde variabelen (indices). 
Voor een groot deel van deze variabelen werden de gegevens in absolute aantallen verzameld. Evenals bij de gedragsvariabelen werden deze aantallen tot verhoudingscijfers omgerekend door ze te betrekken op de voor hen meest relevante noemer. Bijlage I bevat een overzicht van deze onafhankelijke variabelen met vermelding van de gegevens waarmee ze zijn berekend en de bronnen waaraan de gegevens werden ontleend.

Ook de frekwentieverdelingen van de onafhankelijke variabelen kenmerken zich door een, meestal positieve, scheefheid. Daarom werden deze frekwentieverdelingen getransformeerd tot indelingen in gelijke interval-klassen, waarbij de extreme waarden in open klassen werden samengenomen. In bijlage $V$ worden de variabelen, ingedeeld naar de onderscheiden omgevingsaspekten, statistisch beschreven. In een zestal tabellen worden de spreidingsbreedte en de centrale tendentie van de frekwentieverdelingen voor de totale onderzoekspopulatie weergegeven, terwijl de spreiding over de urbanisatiegraadcategorieën in gemiddelde klassescores wordt uitgedrukt (Bijlage $V$, tabelien $V$ 1-6). Met deze variabelen werd de tweede, bijgestelde probleemstelling van het onderzoek onderzocht: vertonen sociale, kulturele, economische kenmerken van gemeenter een samenhang met de verschillende typen van afwijkend gedrag. Vanwege het grote aantal variabelen werd evenwel eerst nagegaan of de verzamelde gemeentekenmerken zouden kunnen worden gereduceerd tot een beperkter aantal dimensies waarmee hun onderlinge samenhangen inzichtelijk worden beschreven.

Daartoe werd een orthogonale componenten-analyse toegepast op de 67 geselekteerde variabelen. ${ }^{2}$ )

De resultaten gaven aanleiding tot varimax-rotatie op zes van de geëxtraheerde principale componenten. Bij de benoeming van de geroteerde faktoren, die tesamen $52.8 \%$ van de variantie binden, is uitgegaan van ladingen van .40 of hoger. In tabel 6 worden ook, tussen haakjes, lagere faktorladingen tot .20 vermeld.

Deze zes faktoren laten zich als goed benoembare dimensies in de gemeentekenmerken interpreteren. In het nu volgende worden de faktoren kort beschreven. 
Tabel ò: Resultaten van de orthogonale componenten-analyse, uitgevoera op 67 kenmerken van 176 Nederlandse gemeenten: Varimax rotatie van zes faktoren $\left.{ }^{*}\right)$

\begin{tabular}{|c|c|c|c|c|c|c|}
\hline Gemeentekenmerken & $F_{I}$ & $F_{I I}$ & $F_{I I I}$ & $\mathrm{~F}_{\text {IV }}$ & $F_{V}$ & $F_{V I}$ \\
\hline 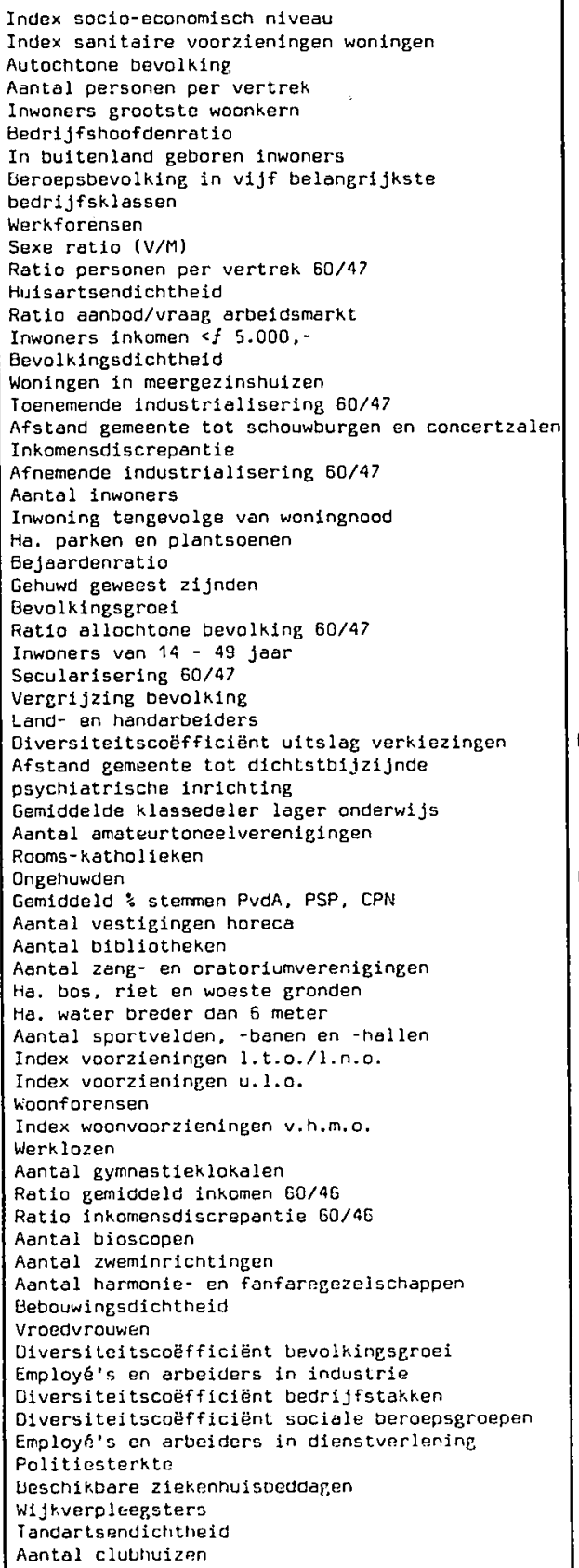 & $\begin{array}{c}.88 \\
-.86 \\
-.79 \\
-.79 \\
.74 \\
-.73 \\
.71 \\
\\
-.79 \\
.69 \\
.68 \\
.61 \\
.61 \\
-.60 \\
-.59 \\
.53 \\
.51 \\
-.48 \\
.48 \\
.47 \\
.45 \\
. .44 \\
(.39) \\
(.34) \\
(.20) \\
(.34) \\
(.38) \\
(.24)\end{array}$ & $\begin{array}{c}.74 \\
.72 \\
-.67 \\
-.66 \\
-.62 \\
-.55 \\
.51 \\
-.47 \\
-.45 \\
-.42 \\
(-.35) \\
(.32) \\
\{-.33) \\
(.31) \\
(.24)\end{array}$ & $\begin{array}{r}.82 \\
.82 \\
-.69 \\
.60 \\
-.56 \\
-.54 \\
.52 \\
-.52 \\
.41\end{array}$ & $\begin{array}{c}(.22) \\
(-.39) \\
\\
.77 \\
.70 \\
-.66 \\
.66 \\
.63 \\
.56 \\
-.48 \\
.47 \\
(.36) \\
(.34) \\
\\
(-.23) \\
(.24)\end{array}$ & $\begin{array}{c}(-.20) \\
.42 \\
.45 \\
(-.23) \\
.51 \\
.40 \\
.62 \\
(.34) \\
(.25)\end{array}$ & $\begin{array}{r}(.22) \\
(-.21) \\
(.20) \\
(-.24) \\
(-.51)\end{array}$ \\
\hline Pr.rcentages verklaarde variaritie & 16.7 & 8.7 & 8.3 & 8.3 & 5.6 & 5.7 \\
\hline
\end{tabular}

-) In Lijlag: VI worden de principale componfinten an hun rotatien volledis: werrenreven. 
Faktor I: welstand - stedelijkhieid

Gezien de hoge ladingen van de index socioeconomische status (.88), de index sanitaire voorzieningen $(-.86)$ en het gemiddeld aantal personen per vertrek (-.79) betreft deze dimensie vooral het welstandsniveau van de gemeenten. Dit blijkt ook uit de negatieve lading voor het \% inwoners met een inkomen van minder dan $f 5.000$,- per jaar $(-.59)$ en de positieve lading van de inkomensdiscrepantie (.47), waarmee een relatief grote inkomensongelijkheid wordt geindiceerd. Een ander belangrijk aspekt van deze dimensie betreft de sociale heterogeniteit: de hoge ladingen van het \% autochtone bevolking $(-.79)$, het \% in het buitenland geboren inwoners (.71), het \% beroepsbevolking werkzaam in de vijf belangrijkste bedrijfsklassen van de gemeenten ( -.71$)$ en de wat lagere ladingen voor de diversiteitscoëfficienten sociale beroepsgroepen (-.33) en uitslag verkiezingen (-.20) wijzen op een sociaal economisch en politiek heterogeen samengestelde bevolking.

Gezien het relatief hoge gemiddelde van het \% beroepsbevolking in de vijf belangrijkste bedrijfsklassen en de bedrijfshoofdenratio in de categorie plattelandsgemeenten (zie tabel V-3, Bijlage $V-2)$-indicatief voor de dominantie van de bedrijfsklasse land- en tuinbouw en de beroepsgroep boeren- kunnen de negatieve ladingen van de beide variabelen (respectievelijk -.71 en -.73) als aanwijzingen voor het stedelijkheidsaspekt van deze dimensie worden opgevat. Dit stedelijkheidsaspekt komt ook tot uiting in hoge ladingen voor morfologische gemeentekenmerken als het \% inwoners in de grootste woonkern van de gemeente (.74), de bevolkingsdichtheid (.38), het \% woningen in meergezinshuizen (.51) en het aantal inwoners $(.44)$ en ook in de lagere, doch eveneens positieve ladingen van de bebouwingsdichdheid (.38) en het \% hectaren parken en plantsoenen (.34). Andere aspekten van deze dimensie betreffen nog de industrialisering en de werkgelegenheid. Blijkens de negatieve en de positieve faktorlading van respectievelijk de toenemende industrialisering $60 / 47(-.48)$ en afnemende industrialisering $60 / 47(.45)$ is er, althans gemeten aan het aantal in de industrie werkzame personen, voor de relatief welvarende en stedelijke gemeenten over de periode 1947-1960 sprake van een tendens tot afnemende industrialisering. Getuige de faktorladingen van het \% werkforensen (.69) en de ratio aanbod/vraag arbeidsmarkt (-.61) ging deze 
ontwikkeling in die periode gepaard met een relatief gunstige werkgelegenheidssituatie.

Indien ook gelet wordt op wat lagere, positieve faktorladingen kan nog worden gewezen op een aantal gemeentekenmerken, die als indicatoren voor de aantrekkelijkheid van de gemeente als woonomgeving zouden kunnen worden beschouwd. Behalve de reeds genoemde parken en plantsoenen en de werkgelegenheidssituatie betreft dit de onderwijsvoorzieningen ( indices l.t.o. .25, U.l.o. .31 en v.h.m.o. .36J, de afstand van de gemeente tot schouwburgen en concertzalen (.48), het aantal sportvelden (.25), het aantal gymnastieklokalen (.33) en het aantal bioskopen (.22).

De overeenstemming in richting vạn deze faktorladingen met ook de andere welstandsindikatoren roept, uiteraard afhankelijk van hun score op deze dimensie, het beeld op van gemeenten die naar welstand en voorzieningen beter of slechter bedeeld zijn en in dit opzicht als woonomgeving meer of minder aantrekkelijk zijn. De tamelijk hoge positieve lading van de huisartsendichtheid (.61) en de lagere, maar eveneens positieve lading van de tandartsendichtheid (.24) zouden als een bevestiging van dit beeld kunnen worden opgevat.

Faktor II: stagnerende groei - vergrijzing Met deze faktor wordt duidelijk een groei- en leeftijdsdimensie onderscheiden. Gelet op de richting van de hoge faktorladingen gaat een, over de periode van 1947-1960 gemeten, geringe bevolkingsgroei (-.67) gepaard met een relatief vergrijsde en vergrijzende bevolking (bejaardenratio .74, \% inwoners van $15-49$ jaar -.62, vergrijzing bevolking 60/47.51). Blijkens de hoge positieve lading van het \% gehuwd geweest zijnden (.72), gaat de vergrijzing van de bevolking gepaard met grotere aantallen alleenstaanden -gezien de positieve lading van de sexe-ratio (.32) vermoedelijk vooral weduwen.

De andere pool van deze dimensie wordt uiteraard gekarakteriseerd door een relatief sterke bevolkingsgroei. Deze bevolkingsgroei lijkt vooral te moeten worden toegeschreven aan een vestigingsoverschot tengevolge van een relatief grote bevolkingstoestroming over de jaren 1947-1960 (ratio \% allochtonen -.66). Hierin ligt ook een mogelijke verklaring voor de toenemende secularisering van de bevolking in geval van een groeiend inwonertal (ratio secularisering $60 / 47-.55)$. 
Faktor III: godsdienst

Uitgaande van de richting van de hoge faktorladingen betreft deze uitgesproken godsdienstfaktor de in het Zuiden en Dosten van het land, in ieder geval in bosrijke en waterarme streken gelegen gemeenten met een hoog percentage roomskatholieken (\% rooms-katholieken .82 , \% ha. bos, riet en woeste gronden . 52, \% ha. water breder dan 6 meter -.52). Zoals te verwachten gaan hogere percentages rooms-katholieken samen met homogenere verkiezingsuitslagen (diversiteitscoefficiënt uitslag verkiezingen .70) en uiteraard relatief lage percentages op de P.S.P., C.P.N. en P.V.d.A. uitgebrachte stemmen $(-.69)$. Omdat de gemeenten, waarvan meer dan $5 \%$ van de bevolking bestond uit vaste bewoners van inrichtingen en tehuizen, waaronder ook de kloosters, niet in de populatie werden opgenomen, moet de verklaring van de opvallend hoge positieve lading van het $\%$ ongehuwden $(.82)$ wel worden gezocht in de gemiddeld hogere leeftijd waarop men in de gemeenten met een overwegend rooms-katholieke bevolking in het huwelijk treedt. Dit zou verband kunnen houden met het lage inkomensniveau van een relatief groot aantal inwoners van deze gemeenten $(\%$ bewoners met een inkomen van minder dan $f$ 5.000,- per jaar .46), waaruit overigens een nog steeds durende nawerking van de vroegere economische achterstelling van de zgn. Generaliteitslanden en de late economische emancipatie van de Nederlandse rooms-katholieken spreekt (Van Heek, 1954).

De andere pool van de dimensie betreft, behalve gemeenten met een relatief hoog percentage onkerkelijken, vooral gemeenten met een hoog percentage protestanten: de nulde orde correlatie van het \% rooms-katholieken met het \% onkerkelijken is -.48 , met het \% protestanten echter -.87 . Dit onderscheid in dominante kerkelijke gezindte (en geografische ligging) gaat samen met verschillen in levensstijl en kulturele oriëntatie, die ondermeer tot viting komen in de wijze van vrijetijdsbesteding. Deze verschillen manifesteren zich in deze faktor middels de tegengestelde ladingen van enerzijds het aantal horeca-vestigingen (.60) en het aantal sportvelden (.41) en anderzijds het aantal bibliotheken $(-.56)$ en het aantal zang- en oratoriumvererigingen $(-.54)$.

Gezien de richting van deze ladingen kenmerken de gemeenten met een hoog percentage rooms-katholieken zich door relatief veel horeca-vestigingen en sportvelden en naar verhouding weinig bibliotheken en zang- en oratoriumvernigingen, 
welke laatste voorzieningen nu juist weer veel meer voorkomen in gemeenten met een hoger percentage protestanten. De faktorladingen van deze variabelen suggereren betreffende de vrijetijdsbesteding in de respektievelijk hoog en laag scorende gemeenten een verschil in gedragsoriëntatie -sociaal gerichte, fysiek ontspannende aktiviteiten in de rooms-katholieke gemeenten versus individueeel gerichte, geestelijk-ontspannende bezigheden in de protestantse of onkerkelijke gemeenten.

Faktor IV: onderwijsfaciliteiten

Met de hoge, positieve ladingen van de index voorzieningen l.t.0./1.n.o. (.77). de index voorzieningen u.1.0. (.70), de index voorzieningen v.h.m.o. (.66) alsook het aantal gymnastieklokalen (.56) betreft deze dimensie hoofdzakelijk de aanwezigheid van scholen voor verschillende typen van voortgezet onderwijs.

Zoals te verwachten vertoont deze onderwijs-dimensie ook een stedelijkheidsaspekt, getuige de weliswaar niet zo hoge, maar positieve ladingen van het aantal inwoners (.40), de bevolkingsdichtheid (.37), het \% woningen in meergezinshuizen (.35) en de bebouwingsdichtheid (.34).

Deze kombinatie van verstedelijking en onderwijsvoorzieningen gaat gepaard met naar verhouding weinig woonforensen $(-.66)$, geringe woningnood $(-.32)$ en hoge percentages werkelozen (.63).

Tesamen met de negatieve lading van de ratio inkomensdiscrepantie 60/46 (.47) indiceren deze variabelen een relatief achtergebleven economische ontwikkeling: over de periode 1946-1960 was er kennelijk sprake van een vergelijkenderwijs geringe groei van het gemiddeld inkomen en van daarmee samengaande geringe vermindering van de inkomensongelijkheid. Gezien deze ladingen zijn waarschijnlijk vooral hoge scores op deze faktor te verwachten van de in economische ontwikkeling enigszins stagnerende provinciestadjes die ten opzichte van de hen omringende regio als onderwijskern fungeren, maar daarnaast als wonomgeving en wat betreft de werkgelegenheid weinig (meer) te bieden hebben.

Faktor V: stedelijkheid - voorzieningendeprivatie De dimensie, die met deze faktor wordt geidentificeerd betreft voornamelijk twee tegengesteld met elkaar samenhangende kenmerken van gemeenten: enerzijds een hoge urbanisatiegraad 
en anderzijds de relatieve afwezigheid van met name rekreatieve voorzieningen.

De hoge urbanisatiegraad van de hoog op deze faktor scorende gemeenten blijkt uit de positieve ladingen van het aantal inwoners (.62), de bebouwingsdichtheid (.47), het percentage woningen in meergezinshuizen (.46) en de bevolkingsdichtheid $(.42)$.

De relatieve voorzieningendeprivatie van deze gemeenten wordt geindiceerd door de negatieve ladingen van het aantal bioskopen (-.55), het aantal zwembaden (-.50), het aantal harmonie- en fanfaregezelschappen $(-.45)$ en het aantal bibliotheken $(-.40)$.

Alhoewel veel lager, correleren alle andere rekreatieve voorzieningen waarvoor gegevens werden verzameld (sportvelden -.32, horecavestigingen -.28, amateurtoneelverenigingen -.26, zang- en oratoriumverenigingen -.22, gymnastieklokalen -.07) negatief met deze faktor, dit met uitzondering van de afstand gemeente tot schouwburg of concertzalen (.51). Dok een aantal andere voorzieningen laadt negatief, zij het zeer laag op cieze faktor: vroedvrouwen -.36, politiesterkte -.15, huisartsendichtheid -.13 en ziekenhuisbeddagen - 05 .

Slechts vier voorzieningen (clubhuizen.19, wijkverpleegsters .18, tandartsendichtheid .17, index voorzieningen v.h.m.0. .12) geven eveneens zeer lage, doch positieve ladingen te zien. De hoog op deze faktor scorende, wat betreft voorzieningen relatief gedepriveerde, grotere steden vertonen bovendien de tendens zich te kenmerken door een grotere woningnood (.34) en een afnemende industrialisatiegraad (afnemende industrialisering $60 / 47.40$ ).

Faktor VI: industrie

Deze laatste faktor tenslotte, kenmerkt zich door een grote mate van eenduidigheid: de hoogstladende variabelen bestempelen deze faktor ondubbelzinnig tot 'industriedimensie'. De hoge, positieve ladingen van het percentage employés en arbeiders werkzaam in de bedrijfstak industrie (.77), de diversiteitscoëfficiënt bedrijfstakken (.66), de diversiteitscoëfficiënt sociale beroepsgroepen (.65), het percentage land- en handarbeiders (.44) en de negatieve ladingen van het percentage employés en arbeiders werkzaam in de bedrijfstak dienstverlening $(-.61)$ en de bedrijfshoofdenratio (-.40) indiceren tesamen de relatieve dominantie van de bedrijfstak industrie en de sociale beroepsgroep van de in loondienst 
werkzame handarbeiders en de daardoor bepaalde eenzijdigheid van de economische aktiviteiten en de sociale stratifikatie van de gemeentebevolking.

De negatieve, zij het niet zo hoge, lading van de variabele toenemende industrialisering 60/47 (-.35), duidt erop, dat het hier veelal zal gaan om de al wat oudere industriegemeenten. Afgezien van een tendens tot een relatief gunstige werkgelegenheidssituatie (ratio aanbod/vraag arbeidsmarkt -.31) en een wat moeilijk te duiden groter aantal politieambteriaren (politiesterkte.39) geeft deze dimensie geen andere uitgesproken karakteristieken te zien.

3.5 Relaties tussen de dimensies in de gemeentekenmerken en de onderscheiden gedragsfaktoren

De vraag naar de samenhangen tussen gemeentekenmerken en typen van afwijkend gedrag werd nu onderzocht door middel van de berekening van de correlaties tussen de dimensies in de gemeentekenmerken en de onderscheiden gedragsdimensies. Daartoe werden voor de dimensies in de gemeentekenmerken eerst de faktorscores per gemeente berekend, evenals bij de gedragsfaktoren volgens de methode van de kleinste kwadratenschatters.

De gemiddelde score en de spreiding van elk van deze onderling onafhankelijke faktoren zijn respektievelijk 500 en 100 -de spreidingsbreedte varieert: welstand stedelijkheid 275-728; stagnerende groei - vergrijzing 182-695; godsdienst 289-729; onderwijsfaciliteiten 257729; stedelijkheid - voorzieningendeprivatie 223-774 en industrie 289-772.

De scores per gemeente voor elke dimensie zijn, gerangordend in kwartielen, vermeld in bijlage VII.

Voor de gedragsfaktoren werden vervolgens zowel de nulde orde correlaties als de multiple correlaties met de zes dimensies in de gemeentekenmerken berekend. Deze correlaties zijn, evenals de percentages verklaarde variantie weergegeven in tabel 7.

Blijkens de multiple correlaties geldt voor elk van de gedragsfaktoren, dat hun frekwenties niet toevallig gespreid zijn, maar variëren met andere kenmerken van de gemeenten. De mate waarin dit het geval is, verschilt echter nogal. 
Tabel 7: Nulde orde correlaties en multiple correlaties van de dimensies in gemeentekenmerken met de faktoren vluchtgedrag, egressief gedrag en vatbaarheid, berekend over 176 gemeenten.

\begin{tabular}{|c|c|c|c|}
\hline \multirow{2}{*}{$\begin{array}{l}\text { Dimensies } \\
\text { gemeentekenmerken }\end{array}$} & \multicolumn{3}{|c|}{ Gedragsfaktoren } \\
\hline & Vluchtgedrag & $\begin{array}{l}\text { Agressief } \\
\text { gedrag }\end{array}$ & Vatbaarheid \\
\hline $\begin{array}{l}\text { Welstand - Stedelijk- } \\
\text { neid }\end{array}$ & .76 & 26 & - 04 \\
\hline $\begin{array}{l}\text { Stagnerende groei - } \\
\text { Vergrijzing }\end{array}$ & .25 & -.26 & $\cdot .26$ \\
\hline Godsdienst & -.31 & .35 & -.05 \\
\hline $\begin{array}{l}\text { Onderwijsfacilitei- } \\
\text { ten }\end{array}$ & .13 & .34 & -.09 \\
\hline $\begin{array}{l}\text { Stedelijkheid - Voor- } \\
\text { zieningendeprivatie }\end{array}$ & .22 & .23 & .29 \\
\hline Industrie & -.17 & .14 & -.13 \\
\hline Multiple correlatie R & .91 & .67 & .42 \\
\hline Verklaarde variantie & $82.8 \%$ & $45.0 \%$ & $17.6 \%$ \\
\hline
\end{tabular}

De faktor vluchtgedrag geeft de sterkste samenhang met de gemeentekenmerken te zien: de multiple correlatie bedraagt .91, dat wil zeggen dat niet minder dan $82.8 \%$ van de variantie van deze gedragsfaktor door de zes dimensies in gemeentekenmerken wordt gebonden. Het leeuwedeel van de verklaarde variantie komt voor rekening van de dimensie welstand - stedelijkheid: deze dimensie alleen verklaart al $57 \%$ van de variantie van de faktor vluchtgedrag $(r=$ $.76)$.

Hoewel in aanzienlijk mindere mate dragen ook de dimensies godsdienst $(r=-.31)$, stagnerende groei - vergrijzing $(r=.25)$ en stedelijkheid - voorzieningendeprivatie $(r=$ .22) bij tot de verklaring van de verschillen in gemeentelijke vluchtgedragfrekwenties -deze dimensies binden respektievelijk $10 \%$, $6 \%$ en $5 \%$ van de totale faktorvariantie. De dimensies industrie en onderwijsfaciliteiten zijn van weinig belang voor de verklaring van de spreidingsverschillen van het vluchtgedrag ( $r$ is respektievelijk -.17 en .13). 
Voor de faktor agressief gedrag is het totale percentage verklaarde variantie niet alleen lager $(45 \%)$, maar ook gelijkmatiger over de onderscheiden dimensies in gemeentekenmerken verdeeld. Met de dimensies godsdienst $(r=.35)$ en onderwijsfaciliteiten $(r=.34)$ als de belangrijkste (de percentages verklaarde variantie zijn respektievelijk $12 \%$ en $11 \%$ ), dragen de verschillende kenmerkendimensies in ongeveer gelijke mate bij tot de variantie van de faktor agressief gedrag: welstand - stedelijkheid $(r=.26)$ en stagnerende groei - vergrijzing $(r=-.26)$ elk met $7 \%$, stedelijkheid - voorzieningendeprivatie $(r=.23)$ met $5 \%$. Alleen de dimensie industrie $(r=.14)$ levert niet of nauwelijks een bijdrage tot de verklaring van de gemeentelijke verschillen in het voorkomen van geregistreerd agressief gedrag.

Bij vergelijking van de correlaties blijken beide gedragsfaktoren positief samen te hangen met de dimensie welstandstedelijkheid.

Hoewel de samenhang met het vluchtgedrag aanzienlijk sterker is, geldt ook voor het agressief gedrag een duidelijke tendens tot hogere frekwenties in meer welvarende en stedelijke gemeenten. Gelet op het welstandsaspekt van de dimensie zijn de correlaties opvallend te noemen, aangezien volgens de bestudeerde literatuur op het niveau van individuen en van stadswijken hogere frekwenties geregistreerd afwijkend gedrag veelal samenhangen met een lage socioeconomische status. Met name voor het vluchtgedrag, maar ook voor het agressief gedrag is hier op het niveau van gemeenten echter sprake van hogere frekwenties van deviant gedrag in geval van een hoge socioeconomische status (de correlaties van het vluchtgedrag en van het agressief gedrag met de index socioeconomische status bedragen respektievelijk .81 en .19, die met het aantal personen per vertrek respektievelijk -.80 en -.17). Deze uitkomsten versterken het vermoeden, eerder uitgesproken in 53.3 , dat de desbetreffende variabelen op buurtniveau en op gemeenteniveau tegengesteld met elkaar variëren.

De gevonden positieve correlaties stemmen wel overeen met de algemeen in de literatuur gerapporteerde hogere irekwenties van afwijkend gedrag in de grotere steden (de correlaties van het vluchtgedrag en van het agressief gedrag met het aantal inwoners zijn achtereenvolgens .55 en .38). De relatie komt ook tot uiting in de positieve correlaties 
van de beide gedragsfaktoren met de dimensie stedelijkheid - voorzieningendeprivatie.

Het vluchtgedrag en het agressief gedrag verschillen van elkaar in hun tegengestelde correlaties met de dimensies stagnerende groei - vergrijzing en godsdienst.

Voor het vluchtgedrag geldt de tendens tot hogere frekwenties in niet of nauwelijks meer groeiende gemeenten met een vergrijzende bevolking, terwijl ongekeerd hogere frekwenties van agressief gedrag vooral voorkomen in relatief sterkgroeiende gemeenten met een jonge bevolking.

Hogere frekwenties van vluchtgedrag doen zich ook voor in gemeenten met hogere percentages onkerkelijken en/of protestanten.

Overwegend rooms-katholieke gemeenten kenmerken zich echter door hogere frekwenties agressief gedrag. Deze tegengestelde relatie van de godsdienstdimensie met de faktoren vluchtgedrag en agressief gedrag stemt overeen met de sedert lang en internationaal vastgestelde verschillen tussen de roomskatholieke en protestantse gezindte aangaande agressieve kriminaliteit en zelfmoordcijfers. In Nederland vormde de relatief hoge criminaliteit van rooms-katholieken het onderwerp van een intensieve discussie. Omdat deze discussie van belang is voor het te ontwikkelen theoretisch model, zal daaraan in het volgende hoofdstuk uitvoeriger aandacht worden besteed.

De faktor vatbaarheid tenslotte blijkt positief te correleren met slechts twee dimensies in gemeentekenmerken. De scores op de vatbaarheidsfaktor zijn hoger in gemeenten met een stagnerende groei en een vergrijzende bevolking, terwijl ook stedelijke, wat betreft hun (rekreatieve) voorzieningen gedepriveerde gemeenten zich kenmerken door een grotere vatbaarheid van hun bevolking.

Hoewel met name de positieve samenhang tussen de dimensie stedelijkheid - voorzieningendeprivatie en de faktor vatbaarheid met zoals eerder werd opgemerkt (\$ 2.4) zijn associaties aan sociaal gedepriveerde omstandigheden van betekenis lijkt, zijn de correlaties niet al te hoog ( $r$ bedraagt respektievelijk.26 en .29) en verklaren ze achtereenvolgens niet meer dan $7 \%$ en $8 \%$ van de variantie van de faktor vatbaarheid. Blijkens de multiple correlaties van . 42 verklaren de zes dimensies tesamen slechts $17.6 \%$ van de variantie van deze gedragsfaktor.

Afgezien van de mogelijkheid, dat de omgevingskondities, die 
relevant zijn voor de op deze faktor hoogladende verschijnselen zich niet op gemeenteniveau voordoen of niet op gemeenteniveau meetbaar zijn, kan uiteraard ook een onvolledige selektie van zowel gemeentekenmerken als gezondheidsindikatoren oorzaak zijn van de naar verhouding lage multiple correlatie.

Wat de selektie van gemeentekenmerken betreft is het zeer wel mogelijk, dat voor de gezondheidstoestand van de bevolking van belang zijnde omgevingskondities in dit onderzoek ontbreken of zijn ondervertegenwoordigd. Hierbij valt bijvoorbeeld te denken aan omgevingskondities als hardheir sil calciumgehalte van het drinkwater, duur van regenval, mate van luchtvervuiling, geluidshinder e.d.. Vanwege het gemis aan gegevens konden evenmin variabelen worden opgenomen over sociokulturele eigenschappen van gemeenten als de mate van sociale cohesie, de struktuur van de sociale interaktie, de maatschappelijke participatie, de leefwijze en de lokale of kosmopolitische oriëntatie van de bevolking, die evenals de fysieke omgevingskondities op zijn minst genomen waard zijn op hun relaties met de gezondheid en vatbaarheid van de bevolking te worden onderzocht.

De selektie van de gedragsvariabelen werd bepaald door de beschikbaarheid van bruikbare gegevens. Met name gegevens over morbiditeit en ziektegedrag bleken schaars te zijn: ziekteverzuimgegevens waren, voorzover beschikbaar, niet bruikbaar, terwijl gegevens over medische konsumptie zoals geneesmiddelengebruik, bezoeken aan huisartsen, specialisten, poliklinieken, kruidendokters e.d. in het geheel niet aanwezig waren.

Tegen de bedoeling in konden gezondheid, ziektegedrag slechts zeer gedeeltelijk worden gemeten. De mogelijkheid is niet uitgesloten, dat toevoeging van andere gezondheidsindikatoren of ziektegedragvariabelen de gevonden gedragsfaktor en zijn relaties met de gemeentekenmerken zou verduidelijken.

Dit neemt niet weg, dat de vraag of sociale, kulturele, economische kenmerken van gemeenten een samenhang vertonen met de verschillende typen van afwijkend gedrag bevestigend kon worden beantwoord, dat wil zeggen dat voor de onderzochte gedragstypen een aantal strukturele correlaties kon worden vastgesteld.

Deze correlaties bieden interessante informatie over de spreiding van verschillende verschijnselen in hun onderlinge samenhang en zouden eventueel zelfs een typologie van gemeenten 
kunnen opleveren.

Zoals bij de bestudering van literatuur over andere, soortgelijke onderzoekingen al steeds duidelijker was geworden, levert bij de gevolgde opzet van het onderzoek de interpretatie van de gevonden relaties echter moeilijkheden op. Het grootste probleem bij de interpretatie van de samenhangen wordt niet veroorzaakt door het gekozen meetniveau, maar door het gebrek aan een theoretisch kader warbinnen de verklaring van de relaties tussen de afhankelijke en de onafhankelijke variabelen op één en hetzelfde niveau als waarop de metingen worden verricht, zou kunnen worden gegeven.

Door het gemis aan een dergelijk theoretisch kader beperken de resultaten van het onderzoek zich bij de gekozen opzet noodzakelijkerwijs tot statistische verklaringen van de spreidingsverschilien van afwijkend en ziektegedrag in termen van gebonden variantie. De uitkomsten geven niet of nauwelijks een, ook voor doelmatig beleid noodzakelijk, inzicht in de causaliteit van de relaties, lat staan in de werking van de
oorzakelijke faktoren.

Hiermee is de reden gegeven voor de eerder aangekondigde beslissing om bij de verdere analyse af te zien van de oorspronkelijke opzet van het onderzoek en voor de beantwoording van de derde probleemstelling - de verklaring van de spreidingsverschillen van de typen van afwijkend gedrag- te zoeken naar een andere benadering.

Deze beslissing werd aanzienlijk vergemakkelijkt door de omstandigheid, dat uit de literatuurstudie ook inspiratie werd opgedaan voor de konstruktie van een theoretisch model. Behalve aan de behoefte aan een interpretatiekader zou met dit model ook kunnen worden voldaan aan de eis tot eenheid van meet- en analyseniveau. In de nu volgende hoofdstukken worden deze modelkonstruktie en de resultaten van de toetsing van het model beschreven. voor deze toetsing werd uiteraard gebruik gemaakt van het beschikbare variabelenbestand. 
II SOCIALE BEHEERSING EN TYPEN VAN AFWIJKEND GEDRAG - ONTWIKKELING EN TOETSING VAN EEN THEORETISCH MODEL.

4. INLEIDING IN HET THEMA - UITGANGSPUNTEN VAN HET MODEL

De bestudeerde literatuur, alsook de resultaten van de eerste onderzoeksfasen maken duidelijk dat de spreiding van geregistreerd afwijkend gedrag niet toevallig is, maar verband houdt met matschappelijke, economische en kulturele verschijnselen. De nu volgende hoofdstukken behelzen een poging tot de ontwikkeling en toetsing van een theoretisch model, waarmee de tetekenis van die relaties kan worden geinterpreteerú en de verschillen in spreiding van de onderscheiden typen van deviantie kunnen worden verklaard.

Omdanks de onorthodoxe procedure -het model werd immers gekonstrueerd nadat de gegevens waren verzameld en de eerste analyse was verricht- mag het toch niet worden opgevat als een op de bevindingen toegesneden verklaring achteraf. Het uitgangspunt voor het model werd gekozen op grond van theoretische en methodologische overwegingen, de theoretische concepten werden ontleend aan sociologische deviantietheorieën en onderzoekingen, de indikatoren voor de operationalisering van het model werden niet geselekteerd op grond van hun onderlinge samenhangen, maar op basis van hun veronderstelde korrespondentie met de theoretische concepten.

4.1 Uitgangspunten van het model

In de sociologische definitie van afwijkend gedrag als overtreding van geĩnstitutionaliseerde verwachtingen (Cohen, 1960), wordt de benoeming van gedrag als deviant, afhankelijk gesteld van zowel de handeling als de norm die wordt overschreden. Volgens deze opvatting is de deviantie een aan de handeling, op grond van externe kriteria, toegekende waardering, die in net algemeen tot uitdrukking komt in door anderen toegepaste sankties.

Met deze analytisch te onderscheiden aspekten -de handeling en de deviantie- zijn de twee belangrijkste benaderingen van het verschijnsel afwijkend gedrag gegeven (Akers, 1968). De benadering, warin het deviante gedrag centraal staat, concentreert zich op het probleem warom sommige individuen als deviant beschouwde handelingen verrichten -de vraag dus naar de 'behavior producing processes' (Kitsuse en Cicourel, 1963). Bij alle verscheidenheid aan theorieën en 
hypothesen over de oorzakelijke faktoren-variërend van intra-indivicuele psychofysiologische processen tot omgevingseigenschapper: en hoedanigheden van matschappelijke strukturen-, verorderstelt de probleemstelling van deze etiologische benadering steeds een op het niveau van individuen verlopende causaliteit en daarmee het individu als de eenheid van analyse.

Omdat het hier gaat om de verklaring van de aard en de frekwenties van afwijkend gedrag als kenmerken van gemeenten, is afgezien van de etiologische benadering en gekozen voor de benadering, waarin de deviantie van het gedrag centraal staat. In deze benadering gaat het om het probleem waarom bepaalde gedragingen als afwijkend worden gedefinieerd. Deze vraag naar wat de 'deviantie producerende processen' zou kunnen worden genoemd, manifesteert zich in verschillende theorieën en hypothesen, waarin de verklaring voor aard, frekwentie en spreiding van de deviantie wordt gezocht in de maatschappelijke processen waardoor de normen en wetten tot stand komen die bij overtreding afwijkend gedrag opleveren, in het gedragsregulerend vermogen van het normenen waardensysteem, dan wel in de mechanismen waardoor dit systeem wordt geëffektueerd, de konformiteit van het gedrag wordt bewerkstelligd en het afwijkend gedrag geidentificeerd.

Evenals de frekwenties van afwijkend gedrag is de sociale beheersing geen eigenschap van individuen, maar een kenmerk van sociale eenheden als gezinnen, scholen, bedrijven, gemeenten.

De verklaring van de relaties tussen frekwenties van afwijkend gedrag en hoedanigheden van het sociale beheersingssysteem dient ook op het niveau van die sociale eenheden te worden gezocht.

Hiermee is dus het uitgangspunt van het theoretisch model gegeven: verschillen in frekwenties en typen van afwijkend gedrag van bepaalde sociale eenheden worden beschouwd als effekten van Eigenschappen van het sociale beheersingssysteem van die sociale eenheden.

\subsection{Relevante aspekten van het sociale beheersingssysteem}

Bij de uitwer<ing van dit globaal omschreven uitgangspunt ging het om het gezichtspunt van waruit het verband tussen sociale beheersing en deviantie zou worden gelegd, of met andere woorden, om de vraag welke aspekten van de sociale 
beheersing met betrekking tot de spreiding van afwijkend gedrag van belang zijn.

Een hierbij bruikbare benadering betreft het onderscheid tussen de gedragsregulerende en gedragsbewakende aspekten van het sociale beheersingssysteem.

Wat de gedragsregulerende aspekten betreft ligt het aksent op eigenschappen van de sociale beheersing, die de gedragscodes stellen, de keuzemogelijkheden van (legitieme) gedragsalternatieven bepalen en daarmee dus de in principe als afwijkend te beschouwen gedragswijzen definiëren. Bij de gedragsbewakende aspekten gaat het vooral om hoedanigheden van de sociale beheersing, die van invloed zijn op het bekend worden van konkrete normoverschrijdende handelingen en op hun etikettering en sanktionering als deviant gedrag. In dit verband kan worden gedacht aan theorieën en onderzoekingen betreffende 'labeling' van gedrag als deviant (Kitsuse, 1962; Becker, 1963; Scheff, 1966) en de rol van de maatschappelijke reaktie (Erikson, 1962; Scheff, 1964), de hospitalisering van geesteszieken en de matschappelijke afwijzing van sociokulturele minderheidsgroepen (Gibbs, 1962), de sociaal gestruktureerde weerbaarheid van individuen (Rushing, 1971) en de relatie tussen aktiviteiten, beleidsrichtlijnen, behandelingskriteria, aanwezigheid en kapaciteit van korrigerende of behandelende instanties als politie, ziekenhuizen, artsen, en dergelijke, kortom, de 'pakkans' (Jongman et al., 1969) en de frekwenties van bekend gewarden en geregistreerd afwijkend gedrag (Sellin,1951; Kaplan et al., 1956; Shulman,1966; Szasz, 1970; Zola, 1972).

Vanuit de vraag naar de geldigheid van de geregistreerde gedragsfrekwenties werd in de eerste fase van dit onderzoek aandacht besteed aan de gedragsbewakende aspekten van de sociale beheersing. Een groot deel van de geregistreerde gegevens is immers het (bij)produkt van de opsporende, korrigerende of behandelende (hoofd)aktiviteiten van instanties, die expliciet (politie, justitie) of impliciet (artsen, ziekenhuizen) fungeren als instrumenten van de sociale beheersing. De registratiekansen van de desbetreffende afwijkende handelingen zijn dus mede afhankelijk van de eigenschappen van deze 'cijfersproducerende instanties', reden om te underzoeken in hoeverre de verschillen in gemeentelijke frekwenties van geregistreerd afwijkend gedrag kunnen worden toegeschreven aan gemeentelijke verschillen in aanwezigheid en omvang van dergelijke instanties ( $\$ 2.3$ ). 
Wat betreft de gedragsregulerende aspekten van de sociale beheersing kunnen als voorbeelden worden genoemd de studies naar het, met de mate van sociokulturele integratie sanenhangende, gedragsregulerende vermogen van het normatieve syteem en de moord- en zelfmoordfrekwenties (Porterfield, 1951/52), de Amerikaanse geweldtraditie en 'frontier culture' en de proportie vermoorde negers (Pettigrew en Barclay Spier, 1952), de socialisatie van de uiting van agressie en de sociaal gestratificeerde spreiding van moord en zelfmoord (Gold,1958), het door participatie aan het dominante sociokulturele systeem verkregen sociale prestige en het onwettige geboortecijfer (Goode, 1961), de met de mate van sociale integratie variërende sociale onkosten van de echtscheiding en het echtscheidingscijfer '(Fenelon, 1971), de verzwakking van het 'collectieve geweten' gepaard gaand met de ontwikkeling van de arbeidsverdeling en de kriminaliteitsfrekwenties (Webb, 1972).

In deze en dergelijke studies wordt de sociale beheersing opgevat in termen van het normen- en waardenpatroon, van de sociale cohesie en normatieve integratie van de groep en van de binding van het individu aan de gemeenschappelijke kultuur. Wat de effekten van de sociale beheersing betreft gaat het in principe om de mate van sociale dwang, om de begrenzing van de individuele vrijheid van handelen -het centrale thema van de theorieën van Durkheim (Engelse vertalingen, 1952, 1965), die aan verschillende van deze studies ten grondslag liggen. ${ }^{1}$ )

\subsection{De bindingskracht van het normatieve systeem}

Zoals in de hiergenoemde studies tot uiting komt kan wat de gedragsregulerende eigenschappen van de sociale beheersing betreft onderscheid worden gemaakt tussen de inhoud van het normen- en waardensysteem (welke doeleinden worden gesteld, welke gedragingen worden voorgeschreven, getolereerd, afgewezen of verboden) en de mate waarin het normen- en waardensysteem de leden van de gemeenschap in hun handelen bindt (de mate van 'social constraint').

In dit onderzoek is voor de verklaring van de gemeentelijke verschillen in frekwenties en typen van afwijkend gedrag het inhoudelijke aspekt van het normen- en waardensysteem niet relevant.

Als kriteria voor de selektie van de gedragsvariabelen golden ondermeer de volledigheid en de vergelijkbaarheid van 
de gegevens. Alleen dié vormen van afwijkend en ziektegedrag werden bij het onderzoek betrokken, die in alle gemeenten op gelijke wijze worden geregistreerd (\$ 2.2).

In dit opzicht verwijzen de geselekteerde gedragsvariabelen naar landelijke, voor alle gemeenten geldende normen en is dus de door Galtung (1969) geciteerde uitspraak van Lazarsveld en Menzel van toepassing: 'Contextual properties are meaningless when there is only one collectivity involved, because all subunits of that collectivity would take on the same value since they are all members'.

Hoewel de registratiekansen per individuele handeling varieren, hebben alle met gedragsvariabelen aangeduide gedragscategorieën in elke gemeente een in principe gelijke kans op registratie. Een nul-score van een gemeente op een bepaalde gedragsvariabele betekent dan ook niet, dat de desbetreffende gedragingen in die gemeente niet voor registratie in aanmerking komen, maar heeft de voor alle gemeenten gelijke betekenis, dat gedurende de periode waarover de gegevens werden verzameld deze gedragingen zich niet hebben voorgedaan of niet ter kennis van de registrerende instanties zijn gekomen.

Wat betreft de algemene, landelijk geldende registratiecategorieën vormen de daaraan ten grondslag liggende normen op het niveau van gemeenten dus geen variabelen, maar constanten die als zodanig niet kunnen bijdragen tot de verklaring van de gemeentelijke verschillen in geregistreerd afwijkend gedrag. $\mathrm{Er}$ is op het niveau van gemeenten wel sprake van variatie in de plaatselijke interpretaties en accentueringen van de landelijke gedragsnormen, zoals bijvoorbeeld wordt geillustreerd door de bevindingen van Haverda (1955). In zijn onderzoek naar 'sociaal onaangepaste' gezinnen liet Haverda de zogenaamde sleutelfiguren beoordelen welke gezinnen in de gemeente als 'sociaal onaangepast' konden worden aangewezen - dit aan de hand van landelijk geldende kriteria (kinderverwaarlozing, drankmisbruik, criminaliteit en dergelijke). Daarbij bleken identieke gedragingen per gemeente verschillend te warden gewogen. In sommige plattelandsstreken werd bijvoorbeeld incidenteel drankmisbruik streng veroordeeld en werden incest en ontucht met kinderen minder zwaar aangerekend. In andere gemeenten gold juist het omgekeerde. De eventuele effekten van de gemeente-specifieke gedragsregels op de aard en frekwentie van het geregistreerde afwijkend gedrag kunnen echter in dit onderzoek niet worden nagegaan. 
De gedragsnormen werden niet onafhankelijk van het bekend geworden en als afwijkend bestempelde gedrag gemeten. De verklaring van de gemeentelijke verschillen in de frekwentie van afwijkend gedrag uit verschillen in gemeente-specifieke gedragsregels zou daarom neerkomen op een tautologie. In het hier te ontwikkelen theoretische model zal de verklaring van de spreiding van het afwijkend gedrag dan ook niet worden gezocht in de inhoudelijke eigenschappen van het sociale beheersingssysteem, maar in de gedragsregulerende aspekten van de sociale beheersing, die bepalend zijn voor de mate, waarin de kollektieve eisen en verwachtingen de individuele leden van de gemeenschap vrijlaten dan wel beperken in de keuze van hun gedragsalternatieven.

Het gezichtspunt van waruit het verband tussen sociale beheersing en deviantie wordt gelegd betreft dus de begrenzing van de individuele vrijheid van handelen, met andere woorden, de variabiliteit van het gedrag binnen de gemeenschap. De variabiliteit van het gedrag wordt bepaald door de reikwijdte en de geldigheid van het normatieve systeem en door de mate van toezicht, de striktheid van de controle op het gedrag - eigenschappen van de sociale beheersing, die onafhankelijk van de inhoud van de normen en waarden kunnen variëren.

Samenvattend kan worden gesteld, dat in het verklaringsmodel zowel de eventueel per individu of categorie van individuen variërende oorzaken van het gedrag alsook de eventueel per gemeente of categorie van gemeenten verschillende gedragsregels buiten beschouwing worden gelaten.

De verschillen in gemeentelijke frekwenties en typen van geregistreerd afwijkend gedrag worden beschouwd als effekten van:

- gemeentelijke verschillen in de gedragsbewakende eigenschappen van het sociale beheersingssysteem, die van invioed zijn op de registratiekansen van individuele gedragingen,

- gemeentelijke verschillen in de gedragsregulerende eigenschappen van het sociale beheersingssysteem, die de variabiliteit van het gedrag bepalen.

4.4 Kerkelijke gezindte, criminaliteit en sociale beheersing: een illustratieve relatie

Het hier gekozen uitgangspunt is rechtstreeks te relateren aan Durkheim's theorie over de gevolgen van een toenemende 
arbeidsverdeling voor de morele en sociale integratie van de samenleving. In zijn 'De la Division du Travail Social' van 1893 (hier geciteerd in de Engelse vertaling van 1965) poneert Durkheim de stelling dat tengevolge van een toenemende arbeidsverdeling de oorspronkelijke normatieve integratie van de samenleving verzwakt en plaats maakt voor een op funktionele afhankelijkheid gebaseerde integratie, welk proces gepaard gaat met een toenemende variabiliteit van het gedrag.

Deze stelling raakt de kern van het theoretisch model van dit onderzoek. Bij de verdere ontwikkeling van het model zal dan ook uitvoeriger op Durkheim's theorie worden ingegaan.

Daaraan voorafgaande zal echter ter afsluiting van dit hoofdstuk aandacht worden besteed aan een door betrokkenen intensief gevoerde diskussie over de criminaliteit van de Nederlandse katholieken. Deze diskussie zal hier tamelijk uitgebreid worden weergegeven. Niet alleen amdat de schriftelijke neerslag ervan boeiende lektuur vormt, maar vooral omdat bepaalde thema's daarin een interessante illustratie bieden van de effekten van de sociale beheersing zoals bedoeld in de hiervoor omschreven uitgangsstelling van het model en de relatie van het model met Durkheim's theorie verduidelijken.

\subsubsection{De criminaliteit van de Nederlandse rooms-katholieken}

In § 3.5 werd melding gemaakt van het feit dat de relatie tussen kerkelijke gezindte en type van afwijkend gedrag sedert lang de aandacht heeft getrokken. Daarbij werden wat zelfmoord en agressieve criminaliteit betreft internationaal verschillen vastgesteld tussen de rooms-katholieke en protestantse gezindte.

Reeds in 1897 presenteerde Durkheim in zijn werk over de zelfmoord gegevens over hoge zelfmoordcijfers in overwegend protestantse provincies en landen en over hogere cijfers voor moord en doodslag in overwegend rooms-katholieke landen en regio's. Dok daarna zijn dergelijke verschillen herhaaldelijk gekonstateerd, zoals bijvoorbeeld in het onderzoek van whitt et al. (1972), waarin de voor 47 landen berekende zelfmoord-moord ratio na konstanthouding van de industrialisatiegraad in de protestantse landen hoger bleek te zijn dan in de rooms-katholieke landen. Met een incidentele verwijzing naar de lagere zelfmoordcij- 
fers van de rooms-katholieken concentreerde in Nederland de belangstelling zich vooral op hun hogere cijfers voor met name de agressieve criminaliteit.

In de dertiger en veertiger jaren vormde dit verschijnsel het onderwerp van een bewogen gedachtenwisseling binnen de 'Vereeniging tot het bevorderen van de Beoefening der Wetenschap onder de Katholieken in Nederland'.

De normatieve betrokkenheid van de diskussianten blijkt uit de bemantelende verklaringen van de katholieke ruwheidscriminaliteit als voortvloeiend uit 'les défaults de leur qualités' (Feber, 1940), als toch overwegend 'bagatelzaken' (van Rooy, 1940) en niet zo zeer 'delikten, welke in het algemeen met meer overleg en veelal met een chronische asociale gezindheid samengaan . . ' '(Feber, 1933) ${ }^{2}$ ) en vooral uit de moeite, die wordt besteed om aan te tonen dat deze hogere criminaliteit niet indikatief is voor een in verhouding met andere groeperingen en, gezindten grotere immoraliteit van de katholieken.

Zo meent van Rooy bijvoorbeeld, dat 'men. . . zelfs zeer immoreel (kan) leven zonder 'crimineel' te worden, als men maar geen wettelijk strafbare handelingen stelt, of zelfs er maar voor zorgt, dat men het ingrijpen van een strafrechter of een veroordeling -hoe dan ook- weet te ontlopen' en stelt Schmitz, geciteerd door Havermans (1953), met betrekking tot de seksuele misdrijven, dat anders dan de stedelijke bevolking de katholieke plattelander voor seksuele spanningen geen uitlaat heeft middels prostitutie, overspel of echtscheiding - de stedeling heeft daarom niet zoveel moeite de wettelijke strafbare seksuele aberraties te ontwijken, maar kan intussen voor God en geweten crimineler en immoreler zijn dan de katholieke Limburger, die zich niet aan die uitlaatmogelijkheden overgeeft. ${ }^{3}$ )

Het is in dit verband dan ook begrijpelijk, dat de voorkeur wordt gegeven aan, overigens zelden empirisch gefundeerde, verklaringen die de oorzaken van de hogere criminaliteit buiten de katholieke geloofsinhoud en moraal zoeken. Evenals de socialist Bonger (door verschillende auteurs geciteerd) gaat men, zij het op tegengestelde gronden, ervan uit dat er geen verband bestaat tussen geloof en criminaliteit. Waar Bonger bedoelde dat ongeloof geen oorzaak is van criminaliteit ${ }^{4}$ ), daar stellen de desbetreffende katholieke auteurs dat de inhoud van de katholieke gadsdienst en de daarop gebaseerde ethiek niet minder anti-criminogeen is dan de 
protestantse, weshalve zowel voor katholieken als voor protestanten het begaan van een misdaad eigenlijk een teken van ongodsdienstigheid is (van Rooy, 1940).

De eerste vraag die wordt gesteld is dan ook of 'al diegenen die als katholiek worden veroordeeld, volwaardig katholiek (zijn)?' Volgens Feber (1933) blijkt bij navraag onder reklasseringswerkers het aandeel der non-paschanten onder (gevangen zittende) criminelen doorlopend aanmerkelijk hoger dan onder de niet-criminele bevolking. ${ }^{5}$ )

Echte misdadigers zijn, hoewel niet per se atheist, evenmin godsdienstig, of zoals een door Feber geciteerde reklasceringswerker opmerkt: 'Het zijn geen atheisten, maar het zijn menschen in een staat van geestelijke verslaptheid, van doffe, laksche onverschilligheid of totale ongeregeldheid'.

Ook van Weringh (1968), die overigens tot de konklusie komt dat er ten aanzien van het verband tussen criminaliteit en kerkelijke gezindte nog steeds weinig of geen kennis bestaat die de toets der kritiek kan doorstaan, wijst erop dat de geregistreerde kerkelijke gezindte weinig zegt over de al dan niet aanwezige religieuze oriëntatie en derhalve niet bruikbaar is als indicator voor een eventuele relatie tussen geloof en criminaliteit.

Met deze niet nieuwe, maar daarom nog niet minder juiste konstatering wordt echter het probleem niet opgelost, doch alleen verschoven.

Zelfs al zou de criminaliteit inderdaad voor het grootste deel moeten worden toegeschreven aan 'rand'-gelovigen, 'papieren'-gelovigen of afvalligen, dan zou toch wil men althans daaruit de verschillen in criminaliteitscijfers tussen de kerkelijke gezindten verklaren, moeten worden aangetoond, hetzij dat de rooms-katholieke gezindte een naar verhouding aanmerkelijk groter aantal 'rand'-gelovigen of afvalligen telt dan de protestantse gezindten, hetzij dat juist de rooms-katholieke afvalligen de neiging vertonen tot misdadigheid te vervallen.

Zoals verderop nog zal blijken, wordt deze laatste hypothese aangehangen door van Rooy. Dit geldt niet voor de verklaringen waarin de hogere criminaliteit van de rooms-katholieken wordt beschouwd als een effekt van de biecht (vanwege de mogeijjkheid absolutie te verkrijgen tilt de rooms-katholiek niet zo zwaar aan een overtreding van de rechtsregels) dan wel als een gevolg van de strakke en ver-doorgevoerde leiding van de geestelijkheid: de inmenging van de geestelijke herders in zelfs de 
dagelijkse dingen van het leven werkt een minder zelfstandige karakterontwikkeling, geringe levenservaring en een weinig geoefend moreel oordeelsvermogen en daarmee dus een verzwakte morele weerstand in de hand.

Wat betreft de biecht menen zowel Feber als van Rooy, dat dit negatieve effekt, waartegen de geestelijkheid, als het goed is, waakt, hoogstens voorkomt bij lieden die vanuit een primitieve mentaliteit de biecht misbruiken en dat dit effekt als zodanig dus moet worden toegeschreven aan eigenschappen van de biechteling en niet aan de biecht als instituut, dat naar zijn wezen juist anti-criminogeen is (schuldbesef, kontrole en leidingl.

De strakke leiding van de geestelijkheid is volgens Feber geen oorzaak maar juist gevolg van een geringere zelfstandigheid -geestelijke leiding wordt gegeven omdat deze nodig is, de katholieken zijn kultureel en moreel minder zelfstandig.

Van Rooy merkt op dat deze strakke leiding in ieder geval al niet geldt voor de criminele 'rand'-gelovigen. Waar de geestelijke leiding wel wordt uitgeoefend heeft deze eerder een anti-criminogene uitwerking: ook bij de protestanten worden de kerkelijke tucht en het gezag van Gods woord en van zijn dienaren juist als criminaliteitsremmende faktoren gezien. Hij voegt daaraan toe, dat indien deze leiding, zoals wel wordt beweerd, inderdaad ontaardt in een bemoeizuchtige betutteling, dit dan niet pleit voor het karakter en de persoonlijkheid van de leek, die zich deze bedillerigheid van de geestelijkheid laat welgevallen.

Deze uitspraak ontlokt aan Havermans (1953) de opmerking dat dit wel waar kan zijn 'maar intussen gebeurt het toch maar!' Hij stelt, dat met name de 'baldadige, uit suggestie voortvloeiende of explosieve' agressieve criminaliteit moet worden gezien als een uiting van psycho-infantilisme, welke gesteldheid door een heteronome moraal en een te sterk klerikaal beleid wordt aangekweekt of op zijn minst onvoldoende wordt gekorrigeerd. Hij beroept zich daarbij op Linton's uitspraak, dat psycho-infantilisme vaak ontstaat in gemeenschappen waarin het kultuurpatroon van het kind absolute gehoorzaamheid aan de ouders of hun plaatsvervangers verlangt.

'Welnu', konkludeert hij dan, 'meerdere zenuwartsen hebben opgemerkt dat onder katholieke onderwijzers (-essen) en leraren (-essen) vrij veel neurotische en psycho-infantiele personen voorkomen. . .' Dit zou het gevolg kunnen zijn van 
het vaak ontaktisch-autoritair optreden van wereldvreemde geestelijken - de grote psychische moeilijkheden die daaruit kunnen resulteren laten de leek-leraar de keus 'tussen de vlucht in de neurose en de overplaatsing in het neutrale onderwijs'. Dit laatste zou dan kunnen leiden tot een selektie van de minst-zelfstandige, meest infantiele personen. Behalve het psycho-infantilisme noemt Havermans nog als mogelijke andere tot criminaliteit leidende faktoren een onvoldoende gelegenheid tot ontplooiing van de, blijkens de resultaten van de legertests, in principe wel aanwezige intellektuele en psychische aanleg, waardoor 'psychische stuwingen' kunnen ontstaan, die onder andere in asociaal gedrag naar een oplossing zoeken, de onvoldoende mogelijkheden tot verpleging (dat wil zeggen uit de circulatie nemenl van katholieke geestelijk-onevenwichtigen, die enerzijds door hun recidieve de criminele statistiek blijven beĨnvloeden en anderzijds hun direkte omgeving belasten en deze al dan niet via psychische vitputting tot criminaliteit kunnen brengen en de overbelasting van de grote gezinnen door de hoge geboortefrekwentie en de onvoldoende huishoudelijke hulp, welke omstandigheid via psychische uitputting, verwaarlozing en onvoldoende toezicht op de kinderen tot criminaliteit van ontregelde ouders en/of niet goed opgevoede kinderen kan leiden.

Deze grote gezinnen produceren echter bij voortduring ook de algemeen als een positieve selektie beschouwde geestelijken en religieuzen -een feit dat niet alleen enige twijfel oproept ten aanzien van Havermans' hypothese, maar ook strijdig lijkt met de celibaatheorie van Feber (1933, 1940). Feber stelt in deze theorie, dat de economische, sociale en kulturele achterstand en daarmee de hogere criminaliteit van de rooms-katholieken verklaard moet worden uit een afwijkend biologische opbouw van deze bevolkingsgroep, ten gevolge van een door het celibaat veroorzaakte storing in de voortplantingsverhoudingen. Bij alle zegenrijke eigenschappen heeft het celibaat namelijk ook het nadelige effekt, dat voortdurend een positieve selektie van de bevolking aan het voortplantingsproces wordt onttrokken, waardoor deze funktie in toenemende mate door minus varianten moet worden vervuld. 6 ]

Hoewel met enige volharding bepleit, vindt de celibaattheorie weinig of geen aanhang ${ }^{7}$ ) in ieder geval heeft niemand ooit de moeite genomen de geldigheid ervan te onder- 
zoeken.

Ditzelfde geldt voor theorieën, die de verklaring voor de verschillen in criminaliteitscijfers tussen de kerkelijke gezindten zoeken in verschillende eigenschappen van het Alpine ras beneden en het Noordse ras boven de grote rivieren. Het is daarbij echter niet helemaal duidelijk of deze theorieën vitsluitend op wetenschappelijke of ook op ideologische gronden worden afgewezen -de standpunten kenmerken zich door een zekere ambivalentie.

Duynstee, geciteerd door Kempe (1938) meent dat de rasfaktor voorlopig van geringe betekenis moet worden geacht, wat betreft de relatie tussen criminaliteit en de spreiding van het Alpine ras zijn er teveel uitzonderingen.

Tijdens de diskussie over de door Feber en van Rooy uitgebrachte preadviezen inzake de katholieke criminaliteit (Vereeniging, 1941), merkt Heerkens Thijssen op, dat hij studie heeft gemaakt van de rassentheorieën, 'dat moet men tegenwoordig gedaan hebben', en dat hij tot de konklusie is gekomen dat er 'helemaal geen zuivere rassen bestaan'. Hij vervolgt dan: 'Als dat echter ergens bij ons het geval is, dan is dat bij de door mij reeds geciteerde (rooms-katholieke) Kaninefaten met hun lange gezichten, hun blonde tot rossige haren, menschen van uitgesproken Nordisch ras, waar iedere Duitscher trotsch op zou kunnen zijn. Welnu .. . . J, die Nordische katholieken (. . . ) begaan dezelfde delicten als hun Zuidelijke geloofsgenoten en in dezelfde verhouding'. Ook Feber meent, dat afgezien van het feit dat er duidelijk andere verklarende faktoren zijn aan te wijzen (bijvoorbeeld het celibaat) en het ras als verklaring dus niet zo 'nodig' is, de rasfaktor wat betreft de criminaliteit ook niet eenduidig is in zijn effekten. Hij voegt daaraan toe dat hij bovendien skeptisch staat tegenover de tegenwoordige (1940:) 'verheerlijking van den Nordischen mensch'. Dit neemt niet weg, dat er mogelijk wel enige verschillen in begaafdheid en ook in temperament herleidbaar zijn tot rasverschillen -zo zijn Brabanders en Limburgers enerzijds gemoedelijker, meer vatbaar voor leiding en aanpassing, hulpvaardiger, spontaner en blijmoediger, doch anderzijds ook meer suggestibel, onnadenkender en impulsiever, wat inderdaad tot incidentele ruwheidscriminaliteit zou kunnen leiden. Hoewel dus de rassentheorie in het algemeen wordt afgewezen, genieten de verschillen in temperament dan wel mentaliteit tussen de rooms-katholieken en de protestanten -al dan niet in verband met hun mogelijke, zij het zelden expliciet onder- 
zochte, relatie met criminaliteitsverschillen- ook in bredere kring grote belangstelling.

Daarvan getuigt ondermeer Kruyt's schets van de mentaliteitsverschillen tussen rooms-katholieken en protestanten, waarbij hij zich voornamelijk baseert op een aantal Nederlandse sociografieën.

Wat betreft deze verschillen in mentaliteit, door hem onderschreven als geestelijk-psychische houding, ziet Kruyt (1943) als belangrijkste karakteristiek van de rooms-katholieke kerk haar sterke discipline en in verband daarmee het grote saamhorigheidsgevoel van het katholieke volksdeel, dat vorr een deel moet worden toegeschreven aan de gemeenschappelijke sociale en economische achterstelling en de eeuwenlange sociale isolering van de rooms-katholieke gemeenschappen, maar toch vooral is te danken aan het uitstekend ontwikkelde organisatorisch apparaat van de kerk en de leiding van de geestelijkheid. Met de relatief geringe neiging tot zelfstandigheid en de zwakke zucht tot kritiek bij de gelovigen hebben volgens kruyt deze faktoren een, ook op matschapppelijk en kultureel gebied, hechte samenhang van de roomskatholieken bewerkstelligd.

Het (orthodox) protestantse volksdeel, met zijn 'innerweltliche Ascese', zondebesef en predestinatieleer, kenmerkt zich daarentegen door een diversiteit aan kerkgenootschappen, stromingen en sekten, waarvoor de demokratische kerkorganisatie en de voorkeur voor 'souvereiniteit in eigen kring' tesamen met een sterke neiging tot zelfstandigheid van denken en handelen, zucht tot kritiek, individualisme - volgens sommigen gebrek aan sociaal gevoel en gemis aan gemeenschapszin- aansprakelijk zijn.

Kruyt konstateert daarnaast een met deze dominante karakteristieken gepaard gaand verschil in karakter en levensstijl, dat in het door hem aangehaalde citaat van de protestantse theoloog Lindeboom tamelijk volledig als volgt wordt samengevat: '. . . het gat hier om globale kenmerken. Dan weet ge hoe de rooms-katholiek is, typisch emotioneel-actief, of $\mathrm{zgn}$. reactief, in het algemeen primair, heftig impulsief en expansief, soms wat geneigd tot minder betrouwbaarheid, tot geringer punctualiteit, tot minder ernst, licht levend, met zin voor het viterlijke en meer in het bijzonder voor het esthetische in kleur, lijn, muziek en spel, minder actief en andernemend, traditionalistisch, gemoedelijk en weinig forsch in levenshou- 
ding. Keer deze kenmerken om, en ge hebt den typischen protestant: staag, natuurlijk, actief, meer secundair, minder heftig en impulsief, maar bedachtzamer, ernstig tot het stroeve, punctueel, met weinig zin voor het uiterlijk, althans voor het esthetische, voor kleur, sier en muziek, minder gemoedelijk, maar ondernemend en stoer'. ${ }^{8}$ ) Kruyt herkent met name in de mentaliteit van Kuyper's NeoCalvinistische Gereformeerde Kerk de eigenschappen, die volgens Weber's bekende theorie (Die protestantische Ethik und der Geist des Kapitalismus) de calvinistische protestanten predisponeren tot een groter economische aktiviteit en een voor het kapitalisme bevorderlijke instelling en die hun in matschappelijk en economisch opzicht een voorsprong op de rooms-katholieken bezorgden.

Eveneens onder verwijzing naar Weber meent ook Kempe (1938), die als één der eersten de relatie tussen criminaliteit en kerkgenootschap empirisch onderzocht, dat het verschil in mentaliteit en houding tegenover het saciale en economische leven de belangrijkste oorzaak is van de sociale en economische achterstand van de rooms-katholieken.

Hij wijst erop dat deze achtierstand niet alleen blijkt uit een, onder andere door Bonger en Feber aangetoond, lager opleidings- en beroepsniveau, een relatief hoog percentage ondersteunden en een ondervertegenwoordiging van roomskatholieken in openbare ambten, maar ook uit hun, in vergelijking met de protestanten, late start met de organisatie van het sociale leven in de zin van jeugdwerk, drankbestrijding, arbeidersbeweging en dergelijke -insteliingen waaraen door Kempe anti-criminogene effekten worden toegeschreven. Gezien de in zijn onderzoek (arrondissement Utrecht) gebleken wijzigingen in de aard en omvang van de rooms-katholieke criminaliteit: van uitgesproken pauper- en dronkemansdelikten naar meer ernstige economische delikten (gegevens 1910 - 1914 en 1921 - 1930l met alles bijeen een licht dalende tendens voor de totale criminaliteitsfrekwentie, meent kempe de hogere criminaliteitscijfers van de rooms-katholieken te kunnen verklaren uit hun trage matschappelijke en economische aanpassing en hun late organisatie van anti-criminogene instellingen.

Alle besproken auteurs delen de mening, dat gegeven de door niemand betwijfelde relatie tussen ongunstige sociale en economische kondities en criminaliteit, de evenmin loochenbare sociale en economische achterstand van de rooms-katho- 
lieken als de belangrijkste exogene faktor ter verklaring van de katholieke criminaliteit moet worden beschouwd. Evenzo is er consensus over de noodzaak - wil tenminste de diepere oorzaak ('causa causarum') van de hoge katholieke criminaliteit worden blootgelegd- de vraag naar het waarom van deze sociaaleconomische achterstand te stellen. Wat betreft de beantwoording van deze vraag lopen de meningen echter viteen.

Feber (1940) betwijfelt de geldigheid van Weber's theorie ${ }^{9}$ ) en stelt dat er bovendien andere faktoren zijn die deze achterstand verklaren (zoals bijvoorbeeld het celibaat.). Kempe (1938) acht de door Bonger centraal gestelde verklaring -onderdrukking van de katholieken- te beperkt: er is ook sprake van een economische achterstand in landen waar ze niet werden onderdrukt (Tsjecho-Slowakije, Hongarije). Van Rooy (1940) meent evenwel, dat er zonder enige twijfel sprake is van een nauwe samenhang tussen de katholieke achterstand op sociaal en economisch gebied en de onderdrukking waaraan het katholieke volksdeel vanaf de Unie van Utrecht heeft blootgestaan. Ook na de opheffing van de wettelijke onderdrukking omstreeks 1800 (Bataafse Republiek) bleef de feitelijke achterstelling en isolering duidelijk. voelbaar. 10) Hij vraagt zich echter tegelijkertijd af of deze achterstelling, behalve uit de vooroordelen jegens de katholieke godsdienst en bevolkingsgroep, misschien ook verklaard kan worden uit bepaalde aspekten van de katholieke beginselen, tradities en gewoonten, waardoor katholieken zich bij anderen achterstellen dan wel laten achterstellen. Deze vraagstellirig past in zijn streven te onderzoeken of er sprake is van een rechtstreekse samenhang tussen de hogere criminaliteit der katholieken en de katholieke godsdienst -een hypothese, die door de meeste andere auteurs bij voorbaat wordt afgewezen. Hoewel ook hij ervan overtuigd is, dat het katholieke geloof naar zijn inhoud niet minder anti-criminogeen is dan het protestantse, meent van Rooy deze hypothese toch bevestigend te moeten beantwoorden. Naar zijn mening staat voor het merendeel van de protestanten hun godsdienst, als een voor het persoonlijk inwendig leven geldende privaatzaak, waarover ieder volgens zijn eigen geweten dient te beslissen op grond van het vrije onderzoek naar de inhoud en betekenis der Bijbelteksten, min of meer los van Staat en samenleving. Voor hen is de wet uitdrukking van de hoogste 
norm voor hun maatschappelijk-zedelijk handelen.

Voor de katholieke leer en opvoeding is evenwel een van de wet onderscheiden, onmiddellijk op de godsdienst opgebouwd complex van morele verplichtingen typerend. Niet alleen geldt voor de katholiek 'dat de verplichtingen ten aanzien van de staat en de gemeenschap primair gezien worden als gebaseerd op godsdienstig-zedelijke verplichtingen', maar 'in onze waardering gaat ook het ene aan het andere vooraf. In onze opvatting weegt de plicht om godsdienstig en katholiek te zijn zwaarder dan elke andere verplichting, zwaarder ook dan de plicht te gehoorzamen aan de burgerlijke overheid'.

In het feit dat voor katholieken hun verantwoordelijkheid ten opzichte van de staat slechts een uitvloeisel is van hun verantwoordelijkheid ten opzichte van God en de eigen moral hoger staat dan de in de strafwet vervatte gedragsregels en er voor hen (dus) een groter gevaar bestaat 'dat godsdienstverslapping en geloofsverval tevens zal leiden tot daling van het algemene morele peil' ziet van Rooy de grond voor de hypothese, dat de hogere criminaliteitscijfers van de katholieken (mede) verklaard moeten worden uit de, in vergelijking met hun protestantse equivalenten, sterkere neiging van de katholieke afvalligen tot misdadigheid te geraken. ll)

Echter, niet alleen voor 'afzakkende' of 'afgezakte' katholieken, maar voor de gehele groep kunnen de specifieke moraliteitsopvattingen in de bestaande maatschappelijke verhoudingen der moderne samenleving ertoe leiden, dat zij gemakkelijker met de strafrechter in aanraking komen dan andere groepen die overigens door dezelfde criminaliteitsfaktoren worden beinvloed. Waar in het algemeen voor de niet-katholiek de wet en de daarin neergelegde sanktie de maatstaf vormen voor de ernst van het maatschappelijke kwaad, daar is echter voor de katholiek 'veel kwaad tegenover den evenmens, dat wettelijk niet strafbaar is, heel wat ernstiger dan menig kwaad dat de wet als misdrijf of overtreding kwalificeert. Denken we bijvoorbeeld maar aan allerlei komplikaties van het moderne zakenleven, aan allerlei niet strafbare ontuchtige handelingen, aan prostitutie en zelfmoord, aan het gebruik zelf van neomalthusiaanse middelen en niet minder aan het in de hand werken van de geboortebeperking door een bepaald systeem van woningbouw, salariëring e.d., veel kwaad dat toch 
ook uit sociaal oogpunt afkeuring verdient en in ieder geval de morele persoonlijkheid diep kan krenken'.

Volgens van Rooy is het, gezien dit verschil in maatstaf, mogelijk dat 'wij met onze meer op het innerlijk gerichte morele norm soms aan het sociaal zedelijkheidsaspekt tekort doen'. Niet alleen is het, speciaal voor de minder ontwikkelde, katholiek vaak moeilijk het onderscheid in te zien tussen moreel-ongeoorloofde, doch wettelijk niet-strafbare en in moreel opzicht minder zwaar wegende, doch wettelijk strafbare handelingen 12 , maar het laat zich ook indenken, 'dat een katholiek, die zich om een moeilijke, bijvoorbeeld economische, situatie te boven te komen geplaatst ziet vocr. de keuze van een niet-strafbare, maar meer immorele en een wel strafbare minder immorele uitweg, eerder nog de 'criminele' weg zal kiezen'. Zo beschouwd behoeft dus 'een hoger criminaliteitscijfer niet alleen niet op een lager zedelijk gehalte te wijzen, maar dan kan het zelfs tot op zekere hoogte evengoed een indikatie voor een hoog moreel peil inhouden'. Behalve rechtstreeks, kunnen de katholieke morele opvattingen, als oorzaak van de maatschappelijke en economische achterstand, de criminaliteit ook indirekt beínvloeden.

Van Rooy stelt, dat katholieken niet minder ondernemingszin vertonen dan hun andersdenkende medeburgers 'indien zij dat tenminste kunnen doen zonder hun katholieke zedelijke beginselen prijs te geven'. Gezien 'het niet geheel en al aangepast zijn van onze samenleving aan de katholieke mentaliteit' ligt daar de diepste grond, waarom de katholieken in de huidige sociaaleconomische ordening gedwongen kunnen zijn zich bij anderen achter te stellen.

Opkomende moderne stromingen, sociale bewegingen en nieuwe economische instellingen zijn in hun oorspronkelijke verschijningsvorm vaak in strijd met de katholieke moraal. Anders dan de protestanten, die een dergelijk konflikt tussen maatschappij en religie niet kennen en zich dan ook gemakkelijker aanpassen aan 'de nieuwere opvattingen omtrent het niet aan morele normen onderworpen zijn, doch volgens vaste wetten funktionerend economisch leven' (Kempe, 1938), kwamen de katholieken uit bezorgdheid voor de ongereptheid van geloof en zeden slechts 'aarzelend' en 'schoorvoetend' tot de akseptatie van de kapitalistische ordening. 13) Hoewel van. Rooy van mening is, dat deze bezorgdheid soms onnodig en overdreven konservatisme in de hand heeft gewerkt stelt hij dat 'een volledige aanpassing aan een niet op katholieke beginselen gebaseerde matschappij (. . . ) 
voor ons slechts mogelijk (zou) zijn op straffe van het prijsgeven of verslappen van onze beginselen op matschappelijk gebied ..........'.

Zijn uiteindelijke konklusie, dat tenslotte 'de gadsdienst' zelf en de inrichting van de samenleving de twee dieper liggende faktoren zijn 'die voor de gehele plaatsbepaling van de Katholieken in het moderne leven zowel onder sociaaleconomisch als crimineel opzicht in laatste instantie verantwoordelijk zijn', doet hem dan ook met Pompe betwijfelen of de hogere criminaliteit zonder meer als een 'ongunstig teken' of een 'bedenkelijk symptoom' voor het katholicisme moet worden beschouwd.

In zijn repliek naar aanleiding van de discussie over zijn, met instemming ontvangen, praeadvies (Vereeniging, 1941) is deze twijfel verdwenen. Hij zegt daarin: 'Wanneer we ons criminaliteitscijfer in dat grotere kader van onze Katholieke geestesgesteldheid zien en speciaal in verband met de nauwe connectie, die er bij ons bestaat tussen het godsdienstig en maatschappelijk leven, dan voel ik me -hoe paradoxaal het ook klinke moge- zelfs geneigd mijn repliek aldus te besluiten: laat ons ons hoger criminaliteitscijfer maar houden, mits de band tussen ons godsdienstig en sociaal leven dan maar niet in die mate verslapt, zoals we bij een groot deel van andere Christelijke bevolkingsgroepen waarnemen. Indien we dat maar weten te vermijden, dan zullen we het minder gunstige gevolg, dat volgens mij uit dat grote goed voortvloeit, namelijk onze hogere criminaliteit, als het dan niet anders kan, maar met een gerust geweten op de koop toe aanvaarden volgens de gulden regel: van twee kwaden moet men het minste kiezen'.

4.4.2 Overeenkomsten met thema's uit de sociologische literatuur De repliek van van Rooy vormt een frappante context voor de relaties van de beide gedragsfaktoren met de godsdienstdimensie, welke dimensie ondermeer wordt gekenmerkt door een hoge (.82) positieve lading van de variabele $\%$ rooms-katholieken' ( $\$ 3.4$, tabel 6). Gelet op de negatieve correlatie van de godsdienstdimensie met de faktor vluchtgedrag $(r=-.31)$ en de positieve correlatie met de faktor agressief gedrag $(r=.35)$ ( $\$ 3.5$, tabel 7) lijkt zijn wens, althans voor de rooms-katholieke gemeenten uit dit onderzoek, in vervulling te zijn gegaan. ${ }^{14}$ ]

Dit is echter niet de enige reden waarom de uitspraak van van Rooy woordelijk werd geciteerd. 
Van Rooy's repliek is illustratief voor een thema, dat van oudsher ook in de sociologische theorieën over afwijkend gedrag een centrale plaats inneemt.

Behalve in de relatief lage socioeconomische status als belangrijke exogene faktor worden in de hier weergegeven diskussie de oorzaken van de hogere criminaliteitscijfers van de katholieke bevolkingsgroep vooral gezocht in eigenschappen van het sociale beheersingssysteem waardoor de katholieke kerkgemeenschap wordt getypeerd. Deze eigenschappen betreffen zowel de inhoud en de reikwijdte van het normenen waardensyteem (de specifiek katholieke moraal), alsook de mechanismen van de sociale beheersing: de hechte kerkelijke organisatie, de biecht, de 'strakke leiding' van de geestelijkheid, de afscherming van de 'niet op Katholieke beginselen gebaseerde' buitenwerelo.

De overeenkomsten met vooral de opvattingen en concepten van Durkheim zijn opvallend. Zowel de inhoud als de toon van de gevoerde diskussie wekken direkt de associatie op met zijn begrip 'collective conscience' (Durkheim, 1965): de rooms-katholiek oordeelt en handelt niet in de eerste plaats op grond van eigen moreel inzicht en geweten, maar ontleent de richtsnoer voor zijn handelen aan de 'collectieve' katholieke moraal, die voor de individuele gelovige niet alleen zijn godsdienstig, maar ook zijn matschappelijk leven tot in bijzonderheden regelt en middels een systeem van kontrole en sankties (doodzonde) zijn alternatieven voor geaccepteerd 'coping behavior' beperkt.

Of, zoals Durkheim (1952) stelt in zijn 'Suicide': 'For it (religious society) does not unite men by an exchange and reciprocity of services, a temporal band of union which permits and even presupposes differences, but which a religious society cannot form. It socializes men only by attaching them in proportion as this body of doctrines is extensive and firm. The more numerous the manners of action and thought of a relegious character are, which are accordingly removed from free inquiry, the more the idea of God presents itself in all details of existence, and makes individual wills converge to one identical goal. Inversely, the greater concessions a confessional group makes vo individual judgement, the less is dominates lives, the less its cohesion and vitality' - 'So if Protestantism concedes a greater freedom to individual thought than Catholicism, it is because it has fewer common beliefs and practices'. 
Met name het betoog van van Rooy vormt een, door zijn moralistische trant nog onderstreepte, illustratie van Durkheim's uitspraken.

De stelling van van Rooy, dat het katholieke geloof naar zijn inhoud niet minder anticriminogeen is dan het protestantse, maar dat, onder bepaalde omstandigheden, de katholieke moraal wel (onbedoelde) criminogene effekten kan hebben, stemt vrijwel letterlijk overeen met Durkheim's opvattingen over de relatie tussen godsdienst en zelfmoord. Hij stelt, dat de godsdienst ten aanzien van zelfmoord een beschermend effekt heeft. 'It is not, as has sometimes been said, because it condemns it more unhesistatingly than secular morality . . .'. - The Protestant believes in God and the immortality of the soul no less than the Catholic' en toch is het zelfmoordcijfer onder protestanten hoger dan onder katholieken. Het verschil in zelfmoordcijfer 'is therefore not due to the special nature of religious conceptions. If religion protects man against the desire for selfdestruction, it is not that it preaches the respect for his own person to him with arguments sui generis; but because it is a society'. Dat wil zeggen: 'Because the Catholic religion imposes on its faithful a vast system of dogmas and practices, and so penetrates all the details of even their earthly life, it attaches them to their life with greater force than Protestantism. The Catholic is much less likely to lose sight of the ties binding him to the confessional group of which he is part, because at every moment this group is recalled to him in the shape of imperative precepts applying to different circumstances of life.' Durkheim (1952) konkludeert dan ook 'that the superiority of Protestantism with respect to suicide results from its being a less strongly integrated church than the Catholic church', welke uitspraak hij generaliseert tot: 'The more weakened the groups to which (the individual) belongs, the less he depends on them, the more he consequently depends only on himself and recognizes no other rules of conduct than what are founded on his private interests.' Met zijn op deze gedachtengang berustende propositie betreffende de egoistische zelfmoord 'springing from excessive individualism', namelijk dat zelfmoord tegengesteld varieert met de mate van integratie van de groep legde hij de basis voor het sindsdien in vele toonaarden bezongen thema van de samenhang tussen sociale en kulturele desintegratie en afwijkend gedrag. 
Een van de varianten van dit thema is terug te vinden in het, in dit verband al eerder genoemde onderzoek van whitt et al. (1972). Zij baseerden namelijk hun, door de onderzoeksresultaten bevestigde, hypothese op het door Henry an Short (1954) ontwikkelde begrip 'external restraint': de mate waarin individuen in hun handelen worden beperkt door eisen en verwachtingen van anderen. 15)

Hun, op Durkheim teruggrijpende, verondersteliing dat een toenemende industrialisering gepaard zal gaan met een afnemende mate van 'external restraint' kan worden beschouwd als het sociologisch equivalent van van Rooy's bezorgdheid over de verslapping van de katholieke moraal als gevolg van een aanpassing aan de moderne maatschappelijke ontwikkelingen.

Hoewel Durkheim, zoals gezegd, in zijn 'Suicide' konstateert dat de cijfers voor zelfmoord en voor moord of doodslag soms gezamenlijk, maar vaker tegengesteld variëren, gaat hij op deze kwestie niet al te diep in. Hij stelt dat hoge frekwenties van de egoistische zelfmoord onverenigbaar zijn met hoge cijfers voor moord of doodslag ondat de kondities voor de egoístische zelfmoord tegengesteld zijn -'mutually exclusive as day and night' - aan die voor moord of doodslag: de sterke nadruk op de waarde van het individu en de zwakke banden met de samenleving predisponeren tot zelfdestruktie, niet tot agressie jegens de samenleving. 'Homicide depends on opposite conditions', namelijk een hechte sociale integratie, een sterk ontwikkeld, homogeen normen- en waardenstelsel en een geringe nadruk op het individuele: '..... weak individuation ..... impels to homicides', want 'The less respect there is for individual persons, the more they are exposed to violence, while this violence at the same time appears less criminal' 16) 'when one is trained to think little of his own life, he cannot have much regard for another's.'

De kondities voor de agressie, die tegen anderen wordt gericht, stemmen overeen met die voor de altruIstische zelfmoord. Ondat deze kondities zich volgens Durkheim echter alleen voordoen in primitieve samenlevingen en in het leger, moet de ook in moderne en beschaafde samenlevingen wel voorkomende gezamenlijke variatie van het moord- en het zelfmoordci.ifer aan een andere oorzaak worden toegeschreven, namelijk de anomie. Met dit begrip doelt Durkheim op een toestand, waarin door maatschappelijke, met name economische, veranderingen het geldende normatieve stelsel zijn gedragsregulerend vermogen 
verliest en de samenleving niet in staat is het individu in zijn behoeften, strevingen en handelen te beheersen. 'Anomy, in fact, begets a state of exasperation and irritated weariness which may turn against the person himself or another according to circumstance . . .'.

Hier frappeert de overeenkomst met de hypothese van van Rooy, waarin hij stelt dat de hogere criminaliteitscijfers van de katholieke (mede) verklaard moeten worden uit de in vergelijking met protestanten, voor katholieken grotere kans, dat 'godsdienstverslapping' gepaard gaat met een 'daling van het algemene peil', weshalve de katholieke afvalligen een sterkere neiging vertonen tot misdadigheid te geraken. Voor de katholiek met zijn van huis uit sterke, door zijn geestelijke leiders nauwgezet bewaakte, binding aan de kollektieve moraal van de kerk, zou de situatie waarin deze binding teloor is gegaan en de geestelijke leiding is weggevallen inderdaad als anomisch kunnen worden gekarakteriseerd. 
5.1 Sociale beheersing en de variabiliteit van het gedrag - de theorie van Durkheim

Naar aanleiding van de weergegeven diskussie rond de criminaliteit van de rooms-katholieke bevolkingsgroep in Nederland, waaraan het werkingsmechanisme van de relatie tussen sociale beheersing en afwijkend gedrag werd gedemonstreerd werd in het vorige hoofdstuk een illustratief gebruik gemaakt van uitspraken en begrippen van Durkheim.

In dit hoofdstuk zal de theorie van Durkheim over de gevolgen van de arbeidsverdeling voor de integratie van de samenleving op een meer systematische wijze worden besproken, zodanig dat daaraan toetsbare uitspraken kunnen worden ontleend.

In aansluiting daarop zal het model nader worden uitgewerkt aan de hand van een kritische bespreking van het eveneens op Durkheim's theorie gebaseerde model van Webb (1972).

5.1.1 Normatieve integratie en de invariabiliteit van het gedrag

Bij de ontwikkeling van zijn theorie gaat Durkheim (1965) uit van de normatieve integratie als een typerende eigenschap van samenlevingen met een rudimentaire arbeidsverdeling en een sociale struktuur, die is opgebouwd uit in zichzelf besloten segmenten met een geringe onderlinge samenwerking, kommunikatie en mobiliteit. De geisoleerde segmenten (families, stammen, kasten) kenmerken zich door een grote intensiteit van de interakties en een hoge mate van sociale, economische en kulturele homogeniteit.

Voor deze gemeenschappen is sprake van een normatieve integratie: de binding van de individuen aan de gemeenschap is geworteld in het 'kollektieve geweten' -het gemeenschappelijk geheel van waarden, voorstellingen en sentimenten dat door alle leden van de gemeenschap wordt gedeeld. Durkheim gebruikt in dit verband het bekende begrip mechanische solidariteit.

De sterkte van de normatieve integratie is afhankelijk van de verhouding tussen enerzijds de reikwijdte van het kollektieve geweten (de levenssferen die er door worden bestreken) en anderzijds de vrije marge voor het individuele geweten, van de intensiteit van het kollektieve geweten en van de mate van consensus -hoe preciezer de kollektieve voorstellingen 
zijn gedefinieerd des te minder ruimte er is voor individuele divergenties.

Het gezag van het kollektieve geweten berust, als eerbiedwaardig produkt van het verleden, op de autoriteit van de traditie -de kollektiviteit vormt de centrale waarde. De gedragsregels hebben dan ook primair de bedoeling de traditionele waarden van de kollektiviteit en daarmee de kollektiviteit zelf te beschermen. Afwijking van de regels is daarom niet storend, onwenselijk of afkeurenswaardig, maar vormt een regelrechte bedreiging van de gemeenschap; normoverschrijding wordt beschouwd als een door de kollektiviteit te bestraffen misdrijf. I) De sankties betreffen niet het herstel van verstoorde relaties of de vergoeding van geleden schade ('restitutive sanctions') maar bestaan uit leed-toebrengende straffen ('repressive sanctions'). Volgens Durkheim is de dominantie van het type wet, waarin overtredingen met repressieve sankties worden bedreigd, indikatief voor een normatief geintegreerde gemeenschap.

Naarmate de normatieve integratie sterker en de reikwijdte van het kollektieve geweten dus groter is, geldt voor de leden van de gemeenschap een beperktere individuele vrijheid van handelen, wat tot uiting komt in een geringere variabiliteit van het gedrag.

5.1.2 De gevolgen van de arbeidsverdeling

Durkheim benadrukt vervolgens, dat de ontwikkeling van de arbeidsverdeling leidt tot verzwakking van de mechanische solidariteit, welke plaats maakt voor een organische solidariteit. De binding van de individuen aan de gemeenschap berust steeds minder op hun participatie aan het kollektieve geweten en steeds meer op hun groeiende onderlinge funktionele afhankelijkheid. De normatieve integratie verandert in een funktionele integratie.

Hij ziet de ontwikkeling van de arbeidsverdeling als het gevolg van een toenemende interaktiefrekwentie (morele dichtheid), voortvloeiend uit een groeiende omvang (sociaal volume) en een sterkere concentratie van de bevolking (fysieke dichtheid). Met de ontwikkeling van de kommunikatie en transport noodzaken deze kondities volgens Durkheim terwille van de overleving tot zowel konkurrentie en specialisatie als samenwerking en interaktie tussen de sociale segmenten van de samenleving. 
Deze specialisatie en interaktie ondermijnen de mechanische solidariteit. Met de specialisering van de aktiviteiten, taken en funkties van de leden van de gemeenschap komt een individualiseringsproces op gang, dat zich vitbreidt tot ook andere levenssferen.

Als gevolg daarvan vermindert de normatieve consensus, verzwakt de geldigheid, de vitaliteit van de morele aanspraken van de kollektiviteit en neemt de reikwijdte van het kollektieve geweten af ten gunste van het individuele geweten. Dit proces weerspiegelt zich in terreinverlies van het strafrecht ('repressive sanctions'), waaraan steeds mees' levenssferen worden onttrokken ${ }^{2}$ j, dit met één uitzondering. Zoals reeds eerder vermeld (\$ 4.4.2) komt volgens Durkheim het toenemende respekt voor het individu, de verschuiving van het kollektief naar het individu als centrale waarde, tot uiting in een uitbreiding van de strafwetgeving betreffende de bescherming van de persoon en het persoonlijk eigendom. 3 )

Behalve door specialisering en individualisering, leidt de toenemende arbeidsverdellng ook middels de groeiende samenwerking, interaktie en mobiliteit tussen de sociale segmenten van de samenleving tot een verzwakking van hun kollektieve geweten. De konfrontatie met andere normen en waarden draagt bij tot de relativering van het eigen kulturele systeem en de eigen tradities.

Met de zich ontwikkelende arbeidsverdeling geraken de verschillende sociaal-geissoleerde, kultureel-homogene gemeenschappen in toenemende mate betrokken bij een funktioneel samenhangend systeem met een heterogene kultuur. De kulturele verscheidenheid betekent voor het individu onder meer de mogelijkheid het morele referentiekader voor zijn handelen zelf te kiezen -er ontstaat ruimte voor het persoonlijk geweten.

Uit Durkheim's betoog valt overigens af te leiden, dat hij de toenemende arbeidsverdeling en de daarmee gepaard gaande verzwakking van de normatieve integratie niet als de enige oorzaak van de grotere morele vrijheid van handelen beschouwd. De faktoren, die naar zijn mening de ontwikkeling van de arbeidsverdeling bewerkstelligen (het sociaal volume en de fysieke dichtheid), zijn volgens hem ook rechtstreeks van invloed op de vrijheid van handelen.

Een toenemend sociaal volume en een grotere bevolkingsdichtheid gaan namelijk gepaard met een geringer mate van toezicht, 
een minder strikte kontrole op het individuele gedrag. De grotere interaktiefrekwentie brengt een naar verhouding geringere intensiteit van de interaktie met zich mee. Men kent minder mensen goed genoeg om geinteresseerd te zijn in hun doen en laten -de anonimiteit gaat een rol spelen. Deze omstandigheid leidt ertoe, dat de normoverschrijdingen geen kollektieve reakties meer uitlokken, wat opnieuw een verdergaande verzwakking van het kollektieve geweten bewerkstelligt. ${ }^{4}$ )

5.1.3 Funktionele interdependentie en de variabiliteit van het gedrag

Wat betreft de gedragsregulerende effekten van de sociale beheersing is de centrale stelling van Durkheim's theorie, dat een toenemende arbeidsverdeling middels de differentiering en specialisering van taken en funkties en een grotere sociale en kulturele heterogeniteit leidt tot de verzwakking van de normatieve integratie van de gemeenschap en daarmee tot een grotere morele vrijheid van handelen. Voor de individuele leden van de gemeenschap betekent dit een verruiming van de keuze van, als legitiem beschouwde gedragsalternatieven, wat tot uiting komt in een toenemende variabiliteit van het gedrag.

Deze variabiliteit van het gedrag is echter niet onbegrensd. In de eerste plaats wijst Durkheim erop, dat met een toenemende arbeidsverdeling het kollektieve geweten wel verzwakt, maar niet geheel verdwijnt. Een samenleving kenmerkt zich per definitie door gemeenschappelijke normen en waarden en daarmee dus door een kallektief geweten. De reakties mogen milder en minder algemeen en uniform zijn, vroeger als misdrijf beschouwde gedragingen nu als maatschappelijk probleem worden gezien -bepaalde handelingen worden nog steeds als uitzonderlijke gedragswijzen beschouwd en als zodanig landelijk geregistreerd. Met de accentverschuiving van de kollektiviteit naar de individuele persoonlijkheid als centrale waarde worden zelfs nieuwe elementen aan het kollektieve geweten toegevoegd. ${ }^{5}$ )

Overigens acht Durkheim het kollektieve geweten voor de moraliteit van de gemeenschap van secundair belang. In zijn visie vormt namelijk de arbeidsverdeling als bron van een op funktionele interdependentie gebaseerde organische solidariteit tevens het fundament van een superieure morele orde. 
Een gedifferentieerd, funktioneel interdependent systeem behoeft regeling en coördinatie. Vanuit deze behoefte aan regulatie en beheersing van het systeem ontwikkelt zich een bestuurlijk en administratief apparaat, alsook een veelheid aan wetten, verordeningen en regelingen.

Hoewel deze regels niet minder dwingend zijn en evengoed de individuele gedragsalternatieven beperken meent Durkheim deze morele binding van het individu van een hogere orde te zijn dan die, welke op het kollektieve geweten berust. De morele code, die tot uitdrukking komt in een restitutieve wetgeving is namelijk rationeel. De normen beogen niet de bescherming van traditionele waarden, maar de voorspelbaarheid van het gedrag, de regeling van de onderlinge betrekkingen, de coördinatie van taken en funkties. Wat belangrijker is, deze regels hebben geen betrekking op de individuele handelingssfeer -de binding aan de gedragscode berust niet op het gezag van de traditie, maar, aldus Durkheim, op een vrije keuze van het individu. Anders dan de normatieve binding door het kollektieve geweten, laat de morele code die de organische solidariteit reguleert, het individu ruimte tot eigen beslissingen, tot persoonlijke initiatieven en ontplooiing. Durkheim wijst erop, dat de verzwakking van de normatieve integratie niet alleen de mogelijkheid opent tot persoonlijke ontwikkeling en zelfstandige meningsvorming, maar bovendien vanwege het wegvallen van de oude zekerheden, een behoefte aan nieuwe inzichten en kennis doet ontstaan. Omgekeerd zal de toenemende intellektuele ontwikkeling een verdere relativering en uitholling van de traditionele waarden teweegbrengen. Zijn uitspraken doen een wisselwerking tussen de sterkte van de normatieve integratie en het opleidingsniveau van de gemeenschap veronderstellen. Daarnaast merkt hij op, dat de differentiatie en specialisatie van taken en funkties de noodzaak van een relatief hooggeschoolde beroepsbevolking met zich meebrengen, reden waarom ook een toenemende arbeidsverdeling met een hoger opleidingsniveau gepaard zal gaan.

Deze uitspraken zijn aanleiding om in het hier te ontwikkelen model voor zowel de mate van arbeidsverdeling als de sterkte van de normatieve integratie een samenhang met het opleidingsniveau van de gemeenschap te veronderstellen: Ervan uitgaande dat vanwege de ontwikkeling van bestuurlijke, administratieve en verzorgende funkties en de aanwezigheid 
van diverse opleidingsinstituten met de groei van het sociale volume zowel de behoefte aan als de mogelijkheden tot een hogere scholing zullen toenemen, wordt bovendien een relatie tussen het sociale volume en het opleidingsniveau verwacht.

5.2 Het Durkheimiaanse model van Webb

Anders dan Gibbs en Martin (1958), Dodge en Martin (1970) en Miley en Micklin (1972), die zich voornamelijk baseren op Durkheim's Suicide (1952) en in hun theorieën het etiologische effekt van een afnemende stabiliteit en duurzaamheid van de sociale relaties centraal stellen, gaat Webb (1972) expliciet uit van de zojuist beschreven arbeidsverdelingstheorie van Durkheim.

Aangezien het hier ontwikkelde model is uitgewerkt naar aanleiding van de resultaten van Webb's onderzoek wordt eerst een beschrijving en vervolgens een evaluatie van zijn model en onderzoeksresultaten gegeven.

Webb vat Durkheim's theorie als volgt samen: 'In essence, the authority of the collective conscience diminishes and individual variability increases as the community moves in the direction of increasing size, heterogenity, complexity, and an order of integration or solidarity based on functional or organic interdependence. As these phenomena progress the individual is freed from traditional authority, and much greater variability in his behavior becomes acceptable'. Met de vertaling van 'individuele variatie' in 'deviantie' en rekening houdend met. Durkheim's uitspraken betreffende een toegenomen bevolkingsgrootte en een grotere fysieke en sociale dichtheid als kondities voor de relaties tussen arbeidsverdeling, organische solidariteit en deviantie komt Webb dan tot de volgende formulering van zijn model: 'Accordingly, deviance was considered here as the dependent variable, population size and physical and social density were considered as independent predictor variables, and the division of labor was treated as an intervening variable'. Schematisch weergegeven:

Bevolkingsgrootte $\left(x_{2}\right) \rightarrow$

Bevolkingsdichtheid $\left(X_{3}\right) \rightarrow$ Arbeidsverdeling $\rightarrow$ Deviantie $\left(X_{1}\right) \quad\left(Y_{1}, Y_{2}\right)$

Sociale dichtheid $\left(x_{4}\right) \rightarrow$ 
Aan dit conceptuele model ontleent webb de hypothesen, dat er sprake zal zijn van een direkte relatie tussen de arbeidsverdeling en de mate van deviantie in de gemeenschap en van direkte relaties tussen achtereenvolgens het aantal inwoners, de sociale dichtheid en de fysieke dichtheid en de mate van arbeidsverdeling van de gemeenschap. Voor het aantal inwoners, de fysieke en sociale dichtheid veronderstelt Webb een indirekte relatie met de mate van deviantie in de gemeenschap. Ter operationalisering van het begrip deviantie koos Webb twee indikatoren: vermogensmisdrijven (inbraak, grote diefstallen en autodiefstal) en agressieve misdrijven teger personen (moord, verkrachting, beroving en zware mishandeling).

Het kan worden betoogd, dat vermogensmisdrijven een geldiger indikator voor strukturele veranderingen zijn dan agressieve misdrijven: 'The violent or expressive crime is generally spontaneous or an act of passion, committed without reflexion or premeditation. The property or instrumental offence, on the other hand, is generally the result of rational and motivated behavior, and as such seems a more valid index of the offender's normative orientations, which are in turn a reflexion of the underlying social structure!. Durkheim gaf echter geen enkele reden om alleen vermogensmisidrijven in aanmerking te nemen - volgens Webb sprak hij van misdaad of deviantie als een algemeen begrip. Webb meent daarom dat het gebruik van verschillende indikatoren voor de kriteriumvariabele een geldiger toets van het conceptuele model zal opleveren. Als correlaat voor het begrip arbeidsverdeling gebruikt Webb de spreiding van de beroepsbevolking over de bedrijfstakken, een variabele die identiek is aan de in dit onderzoek opgenomen diversiteitscoëfficiënt bedrijfstakken (Variabele 16, bijlage II).

De bevolkingsgrootte en de fysieke dichtheid worden geindiceerd met de voor de hand liggende variabelen inwonertal en inwoners per vierkante mijl land. In overeenstemming met Durkheim's accentuering van het belang van kommunikatie en transportmiddelen, indiceert Webb de sociale dichtheid ofwel interaktiefrekwentie met de proportie beroepsbevolking werkzaam in de bedrijfstakken transport, openbaar vervoer en kommunikatie.

Deze indikatoren werden gemeten aan 'political, urban places composed of 25.000 or more inhabitants. This included incorporated and unincorporated places as well as the towns, 
townships and counties classified as urban'.

Voor 682 van de in totaal 765 aan deze omschrijving beantwoordende plaatsen waren alle benodigde gegevens over 1960 beschikbaar.

De toetsingsresultaten bleken niet geheel in overeenstemming te zijn met de hypothesen: hoewel in de verwachte richting, is het effekt van de industriële diversiteit op de vermogensmisdrijven gering $(\beta=.17)$ en op de agressieve misdrijven nihil $(\beta=.01)$.

Van de antecedente variabelen heeft daarentegen het inwonertal een onverwacht groot direkt effekt op zowel de vermogensmisdrijven $(\beta=.31)$ als de agressieve misdrijven $(\beta=$ $.42 \mathrm{~J}$.

De onafhankelijke variabelen verklaren tesamen met de interveniërende variabele slechts $16 \%$ en $19 \%$ van de totale variantie van respectievelijk de vermogensmisdrijven en de agressieve misdrijven.

Webb's konklusie is, dat 'Durkheim's model can neitlier be said to be verified nor can it be discarded, for when all the variables are allowed to operate jointly, they have differential but direct impact on the dependent variables. These findings, then, raise the question of why the model did not allow for greater prediction than was attained'.

5.3 Evaluatie van Webb's onderzoek - konsekwenties voor het sociale beheersingsmodel

De beantwoording van Webb's vraag heeft uiteraard konsekwenties voor de conceptualisering en operationalisering van het hier te ontwikkelen model. Het heeft daarom zin wat dieper op deze kwestie in te gaan, dit te meer omdat Webb's eigen verklaringen niet geheel bevredigen.

\subsubsection{Het operationele systeem van Webb}

Wat betreft het operationele systeem noemt webb de keuze van de onderzoekspopulatie en de transversale meting van de variabelen als mogelijke oorzaken van de lage correlaties.

De beperking van de onderzoekspopulatie tot steden met minstens 25.000 inwoners, betekent een geringere spreidingsbreedte van de variabelen. 'Certainly, smaller urban units would have lower measures of industrial diversification, and this alone would increase the range of the measure and thereby possibly increase the predictive accuracy of the variable'. 
Met deze op zich plausibele verklaring beperkt webb zich tot de statistische gevolgen van zijn populatiekeuze. Hij gaat echter niet in op de theoretische konsekwentie die in zijn verklaring ligt opgesloten, namelijk de konditionering van de in het model geponeerde relaties door het niveau van de arbeidsverdeling.

Indien juist, impliceert Webb's interpretatie van de toetsingsresultaten de konklusies, dat hetzij de relaties alleen gelden in geval van aanzienlijke verschillen in de mate van arbeidsverdeling, hetzij de arbeidsverdeling een niveau kan bereiken, waarboven een verdere ontwikkeling de variatiiiteit van het gedrag niet of nauwelijks meer zal beïnvloeden -konklusies, die verwijzen naar een belangrijke konditie voor het theoretische model, warvan de reikwijdte uitgaat boven een beperking van de onderzoekspopulatie naar een bepaald aantal inwoners van de 'urban units'. Webb zelf beschouwt de transversale meting van de variabelen als een belangrijkere beperking van zijn studie.

Omdat longitudinaal materiaal ontbrak, werden de volgens het model causaal gerelateerde verschijnselen gelijktijdig gemeten, dit op grond van de veronderstelling dat het in de tijd gespreide causale proces geldig kan worden geindiceerd met de ruimtelijke spreiding op een bepaald tijdstip van de verschijnselen, die bij dit proces zijn betrokken.

Indien deze veronderstelling onjuist is, kan de transversale meting mede reden zijn van de teleurstellende toetsingsresultaten. Deze mogelijkheid is uiteraard niet uitgesloten -alleen al de met transversaal gemeten gegevens moeilijk te kontroleren ongelijkheid in uitgangspositie van de onderzoekeenheden kan een storende faktor vormen. Zonder toetsing op longitudinaal gemeten gegevens is deze verklaring van de minder gunstige onderzoeksresultaten evenwel niet op haar merites te beoordelen. Overigens zouden, vanwege het risiko op de 'fallacy of the time lag' ( $\$ 1.2$ ), ook in geval van gunstige resultaten zonder herhaalde metingen of anderszins uitgevoerd longitudinaal onderzoek, strikt genomen geen uitspraken kunnen worden gedaan over het procesmatige karakter van de govonden samenhangen. Afgezien daarvan impliceert de veronderstelling waarop de substitutie van longitudinale door transversale gegevens werd gebaseerd, in kombinatie met de populatiekeuze, een belangrijke konditie voor het hier ontwikkelde madel. 
5.3.2 Het ontwikkelingspeil van de samenleving als konditie voor het model

De substitutie van longitudinaal door transversaal gemeten gegevens berust op de veronderstelling, dat het proces van een zich ontwikkelende arbeidsverdeling van een samenleving zich binnen die samenleving niet in een voor alle deelelementen gelijk tempo zal voltrekken, weshalve er voor de mate van arbeidsverdeling en de daarmee gepaard gaande verschijnselen dus sprake zal zijn van plaatselijke verschillen in ontwikkelingsfasen. Met andere woorden: de verschijnselen worden gemeten aan deelelementen van een geheel, dat als zodanig door een bepaald niveau van arbeidsverdeling wordt gekenmerkt.

Gezien de keuze van de populatie waarop het model wordt getoetst (respectievelijk Noord-Amerikaanse steden en Nederlandse gemeenten) betekent dit voor zowel het onderzoek van Webb als het onderhavige onderzoek, dat de geponeerde relaties betrekking hebben op eigenschappen van deeleenheden van een samenleving, die als geheel wordt getypeerd door een relatief hoog-ontwikkelde arbeidsverdeling. Deze konditie bepalt in eerste instantie de reikwijdte van de uitspraken, die op grond van het getoetste model kunnen worden gedaan: de toetsingsresultaten gelden alleen voor geindustrialiseerde samenlevingen met een sterk ontwikkelde arbeidsverdeling.

Daarnaast heeft deze konditie ook konsekwenties voor het model zelf. Als deelelementen van een samenleving met een hoge mate van arbeidsverdeling, participeren de gemeenten in en worden zij beinvloed door het sociokulturele en het economisch-technische systeem van die samenleving. Ook indien zijzelf zich kenmerken door een naar verhouding weinig ontwikkelde arbeidsverdeling, beantwoorden de gemeenten toch niet (meer) aan Durkheim's omschrijving van de in zichzelf besloten, sociaal-geisoleerde en kultureel-homogene segmenten met een ongerept kollektief geweten, die in zijn theorie als startpunt van de ontwikkeling fungeren. Met deze konditie is dus een zekere mate van arbeidsverdeling, van funkionele integratie en van variabiliteit van het gedrag als ondergrens en daarmee dus een beperking van de variantie, gegeven -dit ook in geval de onderzoekspopulatie niet wordt beperkt tot steden met een bepaald aantal inwoners. 
Deze konditie vormt waarschijnlijk ook de reden warom in Webb's onderzoek de hypothesen over het effekt van de bevolkingsgrootte en -dichtheid op de mate van industriële diversiteit niet werden bevestigd.

In een economisch hoogontwikkelde samenleving maakt de voortgaande ontwikkeling en spreiding van de arbeidsverdeling deel uit van een komplex proces, dat in hoge mate wordt beheerst door aan het economische systeem eigen mechanismen. Dit proces speelt zich niet alleen af op plaatselijk niveau (aanwezigheid van ondersteunende industrieën, dienstverlenende bedrijven en geschoolde arbeidskrachten, grondprijzen, gemesntelijke vestigingspolitiek, hinderwetbepalingen), maar ook op nationaal (werkgelegenheidsspreiding, ruimtelijke ordening, investeringsheffingen dan wel subsidieregelingen) en internationaal niveau (technologische ontwikkeling, monetaire verhoudingen, grondstoffenprijzen, invoerbepalingen, marktposities, konjunktuur).

In dit opzicht is Durkheim's theorie dus onbruikbaar. Welke ook de rol van het sociale volume en de fysieke of morele dichtheid moge zijn geweest bij het op gang komen van het door hem beschreven proces, gegeven een bepaald arbeidsverdelingsniveau zal de verdere ontwikkeling vooral door andere faktoren worden bepaald. Gezien deze konditie valt dan ook van de bevolkingsgrootte en -dichtheid geen belangrijke, specifieke bijorage tot de verklaring van de verschillen in de mate van arbeidsverdeling te verwachten.

\subsubsection{Uitbreiding en wijziging van Webb's conceptuele model}

Webb konkludeert op grond van de lage percentages verklaarde variantie tot de noodzaak van wijziging en uitbreiding van het conceptuele model.

Wat dit laatste betreft volstaat hij met de opmerking, dat het model waarschijnlijk onvolledig is, zonder evenwel te specificeren welke variabelen aan het model zouden kunnen worden toegevoegd.

Afgezien van het feit dat een dergelijke vrijblijvende konklusie weinig bijdraagt tot de verheldering van het probleem, is deze omissie nogal verwonderlijk. Immers Durkheim poneert' duidelijk een indirekte relatie tussen de mate van arbeidsverdeling en de variabiliteit van het gedrag -de relatie verloopt via de verzwakking van de normatieve integratie. Het is niet duidelijk waarom Webb, ondanks zijn expliciete verwijzingen naar daartoe strekkende uitspraken van Durkheim, 
in zijn model een direkte relatie tussen arbeidsverdeling en gedragsvariabiliteit meent te moeten veronderstellen en ook achteraf het ontbreken van de normatieve integratie in zijn model niet in overweging neemt als een mogelijke verklaring voor de teleurstellende toetsingsresultaten. Wat daarvan ook de reden moge zijn, de uitkomsten van Webb's onderzoek geven in ieder geval geen aanleiding af te zien van de normatieve integratie als een interveniërende variabele.

In het conceptuele model van dit onderzoek zal dan ook overeenkomstig Durkheim's theorie worden uitgegaan van een indirekte, via de normatieve integratie verlopende, relatie tussen arbeidsverdeling en variabiliteit van het gedrag. Volgens Webb betreffen de wijzigingen van het conceptuele model, die door de toetsingsresultaten worden geindiceerd, vooral de relaties van de deviantie met de als antecedente variabelen beschouwde bevolkingsgrootte en bevolkingsdichtheid. De uitkomsten van het onderzoek doen naar zijn mening twijfel rijzen over Durkheim's aksentuering van de sociale en fysieke dichtheid: '..... although he recognized size as an important variable his emphasis was on density, both physical and social. Increased size was seen as necessary but not sufficient for the advancement of functional differentation'. In plaats van de verwachte direkte relatie met de arbeidsverdeling geven de onderzoeksresultaten echter een rechtstreekse relatie met de deviantie te zien, waarbij bovendien 'size is more closely related to crime.rates than either density or industrial diversification' -een resultaat, dat de noodzaak tot wijziging van het conceptuele model impliceert. Daarbij vormt echter het mechanisme van de direkte samenhang tussen bevolkingsgrootte en criminaliteit een probleem.

Naar de mening van Webb wemelt de literatuur van verklaringen - variërende van oorzakelijke eigenschappen van de sociale omgeving (mobiliteit, normatieve konflikten, verschillen in gelegenheid tot het plegen van misdrijven], 'drift' van criminele personen naar grote steden tot 'differential reporting procedures' en 'perceived differential deterrence' (ofwel verschillen in geschatte kansen op arrestatie en straf)-, die echter als achteraf gegeven, veelal in termen van urbanisme en urbanisatie vervatte interpretaties niet voldoen en weinig bijdragen tot de verheldering en theoretische explicatie van de relatie tussen stadsgrootte en criminaliteitscijfers. 
Op deze konklusies valt echter wel het een en ander af te dingen.

In de eerste plaats veronderstelt Durkheim wel degelijk een direkt effekt van de bevolkingsgrootte en de bevolkingsdichtheid op de individuele vrijheid van handelen, waarbij hij ook het mechanisme van de relatie aangeeft: een toenemende bevolkingsgrootte en -dichtheid leiden vanwege de daarmee gepaard gaande grotere spanbreedte van de kontrole en geringere intensiteit van de interaktie, tot een geringere mate van toezicht op handelen ( 5 5.1.2).

In de tweede plaats geldt Durkheim's stelling over de dichtheid als konditie voor het effekt van het sociale volume voornamelijk de relatie met de arbeidsverdeling. Wat betreft de direkte relatie met de variabiliteit van het gedrag presenteert hij deze interaktie tussen volume en dichtheid als een nog nader te onderzoeken vermoeden.

Daárbij schenkt hij echter al leen aandacht aan de effekten van een grotere dichtheid in geval van een groot volume en blijven de mogelijke konsekwenties van een grotere dichtheid in geval van een gering volume onbesproken.

In het model van dit onderzoek worden beide mogelijkheden verwerkt.

Voor het sociale volume wordt zowel een van de dichtheid onafhankelijk als een door de dichtheid versterkt effekt op de variabiliteit van het gedrag verondersteld, terwijl voor de dichtheid alleen een door het sociale volume geconditioneerd effekt wordt aangenomen.

Wat betreft het sociale volume wordt de redenering van Durkheim gevolgd. Een toenemend sociaal volume bemoeilijkt de kontrole op het gedrag, welk effekt wordt versterkt in geval van ook een grotere dichtheid.

De gratere interaktiefrekwentie zal namelijk leiden tot een naar verhouding geringere intensiteit van de interakties en daarmee tot een verlies aan belangstelling voor andermans doen en laten en een verslapping van de collectieve surveillance. Op grond van deze redenering wordt aangenomen, ten eerste, dat een toenemend sociaal volume, ongeacht de dichtheid, zal leiden tot een geringere mate van toezicht op het handelen en daarmee dus tot een grotere variabiliteit van het gedrag en ten tweede, dat dit effekt van het sociale volume sterker zal zijn naarmate de dichtheid groter is. Wat betreft het direkte effekt van de bevolkingsdichtheid op de variabiliteit van het gedrag wordt een afhankelijkheid 
van het sociale volume verondersteld. Daarbij wordt aangenomen, dat naarmate in kleine gemeenschappen de bevolking sterker geconcentreerd is en dichter bijeen woont, de intensiteit van de interaktie groter zal zijn. Dit betekent niet alleen een grotere mogelijkheid tot kontrole op het handelen, maar ook een sterkere belangstelling voor het gedrag van anderen.

De mate van toezicht op het gedrag zal daarom groter en de vrijheid van handelen dus beperkter zijn. Verwacht wordt, dat dit effekt van de bevolkingsdichtheid verdwijnt of mogelijk zelfs in zijn tegendeel verkeert indien de bevolkingsgrootte toeneemt.

In dit verband kan worden opgemerkt, dat een minder strikte kontrole op het gedrag niet alleen vanwege een grotere tolerantie (of zoals Durkheim stelt, een grotere onverschilligheid) een grotere morele vrijheid van handelen tot gevolg heeft, maar door de kleinere kans op ontdekking en sankties ook een grotere feitelijke vrijheid met zich brengt. Dit impliceert de mogelijkheid, dat het sociale volume en de dichtheid behalve op het bekend worden van voorheen illegitieme, doch nu getolereerde gedragingen, ook van invloed is op de geregistreerde frekwentie van nog steeds als onaanvaardbaar en illegitiem beschouwde handelingen. Wat betreft de relatie tussen bevolkingsgrootte en criminaliteit kan tenslotte worden getwijfeld aan de juistheid van Webb's konklusie, dat verklaringen in termen van 'differential reporting procedures' en 'perceiced differential deterrence' theoretische relevantie missen. Beide verschijnselen verwijzen naar het gedragsbewakende aspekt van de sociale beheersing, dat wil zeggen, naar eigenschappen van het beheersingssysteem, die van invloed zijn op het bekend worden, de 'labeling' en dus de registratiekansen van het afwijkend gedrag.

Hoewel Durkheim het gedragsbewakende aspekt van de sociale beheersing niet expliciet verwerkt in zijn theorie, bieden zijn uitspraken toch voldoende aanknopingspunten om dit aspekt in het conceptuele model te betrekken.

Deze uitspraken betreffen zowel het hier genoemde proces van een afnemende onderlinge kontrole op het handelen als de behoefte aan regulatie en coördinatie van het funktioneel interdependente systeem, die met de zich ontwikkelende arbeidsverdeling gepaard gaat.

Aangaande de regulatie en coördinatie van het in toenemende 
mate gekompliceerde en daardoor ook kwetsbare systeem voorzag Durkheim niet ten onrechte een uitbreiding van de voorschriften, verordeningen en wetten ('restitutive law'), waarin de onderlinge betrekkingen op rationele wijze worden geregeld. Daarnaast mag worden aangenomen dat sprake zal zijn van een groeiende behoefte aan mogelijkheden en instrumenten tot beheersing van en kontrole op verschijnselen en gedragingen, die voor het systeem en voor de gemeenschap als storend worden beschouwd, dit te meer vanwege de afnemende intensiteit van de onderling door de leden van de gemeenschap uitgeoefende kontrole op het handelen.

In dit model wordt verondersteld, dat deze faktoren leiden tot een proces, waarin de kontrole op en de korrektie van storend gedrag als diffuse funkties van de gemeenschap worden overgenomen door gespecialiseerde en professionele instanties. Deze instanties (politie, reklassering, voogdijraden, konsultatiebureaus, verzekeringsgeneeskundigen, maatschappelijk werkers etc.J hebben expliciet of impliciet de funktie storend of illegitiem gedrag op te sporen, te behandelen of te korrigeren en zullen dus aldoende bijdragen tot het bekend worden en de registratie van storend en afwijkend gedrag. Omdat deze instanties voor de vervulling van hun gespecialiseerde taken relatief hooggeschoold personeel behoeven, valt aan te nemen dat de omvang en de aanwezigheid van professionele kontrole instanties behalve met de arbeidsverdeling, ook een samenhang zullen vertonen met het opleidingsniveau van de gemeenschap.

Vanwege het veronderstelde verband tussen de intensiteit van de onderling uitgeoefende kontrole op het handelen en de behoefte aan professionele kontrole wordt bovendien een invloed van het sociale volume en de fysieke dichtheid op de concentratie van de professionele instanties verwacht. Daarbij wordt, evenals ten aanzien van de variabiliteit van het gedrag en op grond van dezelfde redenering, een interaktie tussen het sociale volume en de fysieke dichtheid verondersteld.

In het model wordt aangenomen, dat het positieve effekt van het sociale volume op de concentratie van de professionele kontrole instanties in de gemeenschap sterker zal zijn naarmate de fysieke dichtheid groter is. Voor de fysieke dichtheid wordt alleen in geval van een relatief groot sociaal volume een positief effekt van betekenis op de omvang en aanwezigheid van de professionele kontrole instanties verwacht. 


\subsubsection{Webb's operationalisering van de kriteriumvariabelen}

In zijn kommentaar op de resultaten van zijn onderzoek laat Webb de keuze van de indikatoren voor de variabiliteit van het gedrag buiten beschouwing. Evenmin besteedt hij aandacht aan de, zij het niet grote, verschillen in uitkomsten wat betreft de relatie van de industriële diversiteit met respectievelijk de vermogensmisdrijven en de agressieve misdrijuen.

Toch kan de keuze van de indikatoren voor de kriteriumvariabelen mede oorzaak zijn van de teleurstellende toetsingsresultaten en bevatten de verschillende $\beta$-gewichten aanwijzingen voor de wijziging van het conceptuele model. Wat betreft de keuze van criminaliteitscijfers als correlaten voor de variabiliteit van het gedrag beroept Webb zich op Durkheim. Hij geeft toe dat Durkheim nergens in zijn 'The Division of Labor' expliciet aangeeft, dat een toegenomen arbeidsverdeling zal leiden tot een stijging van de criminaliteitscijfers. 'His definition of crime, of course, precluded such a conclusion, for he conceived of crime as actions which offend strongly defined states of the collective or common conscience, as represented in repressive law, and the violation of which engenders punishment rather than restitution'.

De organische solidariteit wordt echter gekenmerkt door 'restitutive law' waarvan de regels buiten het kollektieve geweten vallen. Bovendien verliest het kollektieve geweten zijn intensiteit en 'diminishes as the society becomes more functionally integrated, and thus, by definition, there would be less crime with increased differentiation'.

Webb meent dat 'if we extend these arguments to their logical conclusion, in time nothing will offend the collective conscience. . . and there will be no crime'.

'Durkheim ignored these flaws in logic and instead focused on what has been termed deviance or 'individual variations'. Volgens Webb was dit probleem te vermijden geweest, indien Durkheim misdaad had gedefinieerd als een 'act in violence of a law, for he clearly recognized that the number and variety of special interest laws were increasing. . .', en hij besluit dan met de konklusie: 'Thus the conceptual leap in this research from Durkheim's 'individual variation' and 'divergent tendencies' to deviance, which becomes operationally defined as crime'. 
Afgezien van het feit, dat de logica van Webb's konklusie geen gevoelens van onmiddellijke evidentie oproept, lijkt zijn interpretatie van Durkheim voor verbetering vatbaar. Ten eerste stelt Durkheim nadrukkelijk, dat het kollektieve geweten wel verzwakt, maar niet geheel verdwijnt -in bepaalde opzichten blijkt het zich zelfs uit te breiden. Zijn uitspraken geven geen aanleiding tot de konklusie, dat het door hem beschreven proces uiteindelijk tot de volledige afwezigheid van de misdaad zou leiden.

Ten tweede beschrijft Durkheim de verzwakking van het kollektieve geweten als het proces waarin de normatieve consensus vermindert en de geldigheid en reikwijdte van de morele aanspraken van de kollektiviteit afnemen, waardoor gedragingen die voorheen werden beschouwd als door de kollektiviteit te bestraffen misdrijven (ketterij, geboortebeperking, overspel, zelfmoord, echtscheiding, abortus provocatus) in toenemende mate tot de sfeer van het individuele geweten worden gerekend. Hoewel de verzwakking van het kollektieve geweten een vermindering van het aantal als misdadig beschouwde gedragswijzen impliceert en er in dit opzicht dus inderdaad sprake is ván 'less crime', wijst het op een 'flaw in logic' om, zoals Webb doet, te stellen, dat dan dus per definitie ook de frekwentie van gedragingen, die nog wel als misdrijven gelden, zal afnemen.

Een afnemende reikwijdte van definitie 'crimineel' sluit de mogelijkheid van hoge frekwenties van crimineel gedrag niet noodzakelijkerwijs uit.

Ten derde kan worden gezegd dat Durkheim, ofschoon hij inderdaad misdrijven formeel niet in termen van wetsovertredingen definieert, wel een nauwe relatie legt tussen handelingen, 'which offend strongly defined states of the collective conscience' en de wetten, die deze handelingen met straf bedreigen. Zoals Webb zelf opmerkt weerspiegelt volgens Durkheim het kollektieve geweten zich in de 'repressive law' ofwel het strafrecht.

Het is dan ook de vraag of handelingen (inbraak, diefstal, beroving, mishandeling) die vanwege het strafrecht als misdrijf worden beschouwd, kunnen dienen als geldige indikatoren voor de 'much greater variability', die -zoals webb stelt in zijn samenvatting van Durkheim's theorie- met betrekking tot het individuele gedrag acceptabel wordt.

Op grond van Durkheim's uitspraken zijn de misdrijven ingevolge het wetboek van Strafrecht veeleer indikatief voor het 
domein van de handelingen, die door de kollektiviteit als onaanvaardbaar worden veroordeeld.

Het is daarom zeer wel mogelijk, dat de onverwacht lage percentages verklaarde variantie voor een belangrijk deel moeten worden toegeschreven aan de onjuist gekozen indikatoren voor de kriteriumvariabele. De kans bestaat, dat de indicering van de variabiliteit van het gedrag met gedragingen, die mogelijk wel als strijdig met de gedragscode of als storend voor het systeem, maar in ieder geval door de kollektiviteit niet meer als te bestraffen misdrijven worden beschouwd (geestesziekte, zelfmoord, echtscheiding, geboortebeperking) tot voor het model gunstiger toetsingsresultaten zou hebben geleid.

Deze mogelijkheid is ook webb niet geheel ontgaan, gezien zijn kommentaar bij de beslissing zowel de vermogensmisdrijven als de agressieve misdrijuen te kiezen als de operationele kriteriumvariabelen. Hij wijst daarbij namelijk op de mogelijkheid, dat de vermogensmisdrijven als 'the results of rational and motivated behavior' een geldiger indikator vormen van 'the offender's normative orientations, which are in turn a reflection of the underlying social structure' dan de agressieve, tegen de persoon gerichte misdrijven, die als spontane en gepassioneerde handelingen veelal worden begaan 'without reflection or premeditation'. Het is daarom opvallend, dat Webb geen aandacht besteed aan de verschillende relaties van de industriële diversiteit met de toch kennelijk met voorbedachte rade gekozen deviantieindikatoren -dit te meer, omdat deze verschillen, hoewel niet groot, overeenstemmen met de door zijn kommentaar geĩmpliceerde verwachtingen.

In dit verband lijken de resultaten van een aantal eerder besproken studies van belang. In deze studies werden namelijk steeds voor moord- en zelfmoordcijfers tegenovergestelde relaties met indikatoren van sociale integratie (Porterfield 1951/52, 1952) of economische diversiteit gevonden (Quinney, 1965; Winslow, 1970; Whitt et al., 1972).

Deze resultaten stemmen overeen met de hypothese van Henry en Short (1954) over de mate van 'external restraint' en de richting van de agressie-uiting, met de uitspraak van Palmer (1973), dat niet alleen sociale desintegratie, maar ook een hoge mate van integratie vanwege de intensiteit van de interaktie, strikte rolomschrijving en sterke sociale kontrole met afwijkend gedrag gepaard kan gaan en met Durkheim's 
theoretische opvattingen uit zijn 'Suicide' (1952). Zoals naar aanleiding van de hogere criminaliteit van de door een relatief sterke normatieve integratie gekenmerkte katholieke bevolkingsgroep al werd vermeld (\$ 4.4.2), ziet Durkheim de toenemende individualisering, de verzwakking van de morele binding, het verlies aan sociale cohesie als kondities, die in geval van frustratie predisponeren tot zelfmoord. Moord, als een op anderen gerichte reaktie, heeft daarentegen veeleer een hechte sociale integratie, een homogeen normenen waardenstelsel en een geringe nadruk op het individu als zelfstandige persoonlijkheid als predisponerende kondities. Webb's aanvechtbare keuze van indikatoren voor de kriteriumvariabele en de voor deze indikatoren ongelijke toetsingsresultaten hebben in kombinatie met de aangeduide onderzoeksuitkomsten en theoretische opvattingen konsekwenties voor het conceptuele en het operationele model van dit onderzoek.

\subsection{De concepten variabiliteit en invariabiliteit van het gedrag}

Deze konsekwenties betreffen behalve de interpretatie van de variabiliteit van het gedrag, die met een relatief zwakke normatieve integratie en geringe kontrole op het handelen gepaard gaat, vooral de specificering van de invariabiliteit van het gedrag, die met een relatief sterke normatieve integratie en strikte kontrole op het handelen samengaat.

De variabiliteit van het gedrag wordt hier opgevat in termen van een geringere mate van 'external restraint', een grotere morele vrijheid van handelen en een daarmee gepaard gaande grotere individuele mondigheid en verantwoordelijkheid.

De grotere morele vrijheid van handelen betekent, dat de leden van de gemeenschap bij de oplossing van hun problemen beschikken over een groter aantal legitieme of op zijn minst als tolerabel beschouwde, gedragsalternatieven. Daarbij wordt aangenomen dat in geval van frustratie of 'stress' de grotere mondigheid en verantwoordelijkheid zullen induceren tot een op het individu zelf gerichte reaktie.

Deze interpretatie impliceert de opvatting van de invariabiliteit van het gedrag in termen van een relatief hoge mate van 'external restraint', een geringere morele vrijheid van handelen en een daarmee gepaard gaande beperktere individuele mondigheid en verantwoordelijkheid. De geringere morele vrijheid van handelen betekent een begrenzing van de legitieme gedragsalternatieven waarover de leden van de gemeenschap bij de oplossing van hun problemen 
beschikken. De morele taboe's beperken de mogelijkheden tot een rationele en adekwate probleemoplossing, waarmee een grotere kans op irrationele, inadekwate of illegitieme reakties is gegeven. ${ }^{6}$ ) Daarbij valt aan te nemen, dat in geval van frustratie of 'stress' de relatief geringe individuele mondigheid en verantwoordelijkheid zullen induceren tot een op anderen gerichte agressieve reaktie. Op grond van deze overwegingen wordt in het conceptuele model van dit onderzoek aangenomen, dat de verzwakking van de normatieve integratie leidt tot een geringere mate van 'external restraint', een grotere morele vrijheid van handelen en een grotere individuele mondigheid en verantwoordelijkheid en dat dit proces tot viting komt in enerzijds hogere frekwenties van legitieme, zelfgerichte gedragsvormen en anderzijds lagere frekwenties van illegitieme, agressieve, op anderen gerichte gedragswijzen. 
6 FORMULERING VAN HET THEORETISCH MODEL - SAMENVATTING EN PROPOSITIES

\subsection{Samenvatting}

Het hiervoor beschreven model dient ter verklaring van de gekonstateerde verschillen in spreiding van een aantal vormen van afwijkend gedrag.

Uitgangspunt is de opvatting, dat ongeacht de veelheid en verscheidenheid aan oorzaken van afwijkende gedragingen, die op individueel niveau werkzaam zijn, de keuze van het type afwijkend gedrag mede wordt gekonditioneerd door eigeschappen van het sociale beheersingssysteem van de gemeenschap.

Rekening houdend met het onderscheid tussen de gedragsregulerende en de gedragsbewakende aspekten van de sociale beheérsing werd dit uitgangspunt nader gekonkretiseerd in de stelling, dat de differentiële spreiding van verschillende typen afwijkend gedrag kan worden beschouwd als een effekt van:

- verschillen in gedragsregulerende eigenschappen van de sociale beheersing die van invloed zijn op de mate van individuele vrijheid in de keuze van gedragsalternatieven en daarmee op de mate van variabiliteit van het gedrag;

- verschillen in gedragsbewakende eigenschappen van de sociale beheersing die van invloed zijn op het bekend worden, de 'labelling' en daarmee op de registratie van afwijkend gedrag.

Schema 1

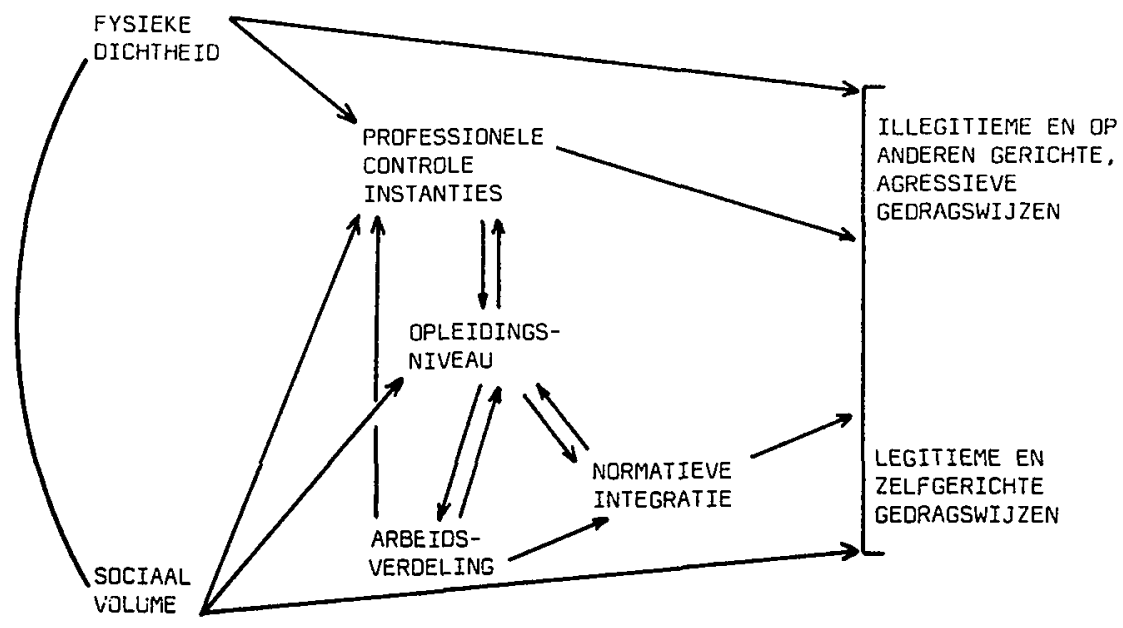


In schema 1 wordt het op basis van deze stelling uitgewerkte model in tekening gebracht.

In het model worden uitspraken gedaan zowel over de effekten van een aantal, zich als kenmerken van gemeenschappen manifesterende, verschijnselen op de te verklaren verschillen in spreiding en typen van afwijkend gedrag, alsook over de onderlinge samenhangen van deze verklarende verschijnselen. Wat betreft de verklaring van de verschillen in spreiding van de onderscheiden typen afwijkend gedrag worden in het model direkte effekten verwacht van de normatieve integratie en de professionele kontrole instanties, alsook in onderlinge interaktie van het sociale volume en de fysieke dichtheid. Voor de arbeidsverdeling wordt op grond van zowel Durkheim's theorie als de toetsingsresultaten van het model van webb (5 5.3.3), uitdrukkelijk en indirekt, via de normatieve integratie en de professionele kontrole instanties verlopend, effekt op het afwijkend gedrag verondersteld.

In het model wordt geen uitspraak gedaan over een direkte relatie tussen het opleidingsnviveau en het afwijkend gedraghoewel Durkheim's uitspraken enerzijds de mogelijkheid van een direkte relatie niet bij voorbaat uitsluiten, bevatten ze anderzijds geen aanwijzingen voor een van de normatieve integratie onafhankelijk mechanisme waardoor deze eigenschap van de gemeenschap de spreiding van het afwijkend gedrag rechtstreeks zou kunnen beinvloeden.

In tegenstelling tot Durkheim's uitspraken dienaangaande, wordt aangenomen dat het sociale volume en de fysieke dichtheid geen effekt van betekenis zullen hebben op de arbeidsverdeling ( $\$ 5.3 .2$ ).

Zoals schema 1 laat zien, ontbreken bovendien verbindingen tussen de professionele kontrole instanties en de normatieve integratie, tussen de normatieve integratie en het sociale volume of de fysieke dichtheid en tussen de fysieke dichtheid en het opleidingsniveau. Om het model niet nodeloos te kompliceren, worden over direkte relaties tussen deze verklarende verschijnselen geen uitspraken gedaan.

Gezien de doelstelling van het model -de verklaring van de verschillen in spreiding van een aantal vormen van afwijkend gedrag- wordt een eenzijdige causaliteit van de relaties verondersteld.

In schema 1 wordt echter in drie gevallen een wederkerige samenhang aangegeven. Dit geldt voor de samenhang van het opleidingsniveau met achtereenvolgens de normatieve integratie, 
de arbeidsverdeling en de professionele kontrole instanties. Voor het opleidingsniveau en de normatieve integratie berust de veronderstelling van een wederkerige relatie op uitspraken van Durkheim, waarin hij de toenemende persoonlijke ontwikkeling en ontplooiing van de leden van de gemeenschap en de verzwakking van het kollektieve geweten als elkaar in onderlinge wisselwerking versterkende processen beschouwt ( $\S 5.1 .3$ )

Voor de relaties van zowel de arbeidsverdeling als de professionele kontrole instanties met het opleidingsniveau geldt de redenering, dat specialisering en professionalisering van taken en funkties gepaard zal gaan met een behoefte aan een relatief hooggeschoolde beroepsbevolking. Hoewel het de samenhangen tussen deze verschijnselen aannemelijk maakt, impliceert dit mechanisme echter geen voorspelling over de richting van de causaliteit van deze relaties. Op grond van dit mechanisme kunnen de verwachte samenhangen namelijk het gevolg zijn van zowel de effekten van de zich ontwikkelende arbeidsverdeling en professionele kontrole instanties op het opleidingsniveau als van een effekt van het opleidingsniveau op de ontwikkeling van de arbeidsverdeling en de professionele kontrole instanties - dit nog afgezien van de mogelijkheid dat de richting van de causaliteit niet voor alle gemeenschappen dezelfde is. Om deze reden wordt in het model geen uitspraak gedaan over de causaliteit van de relaties, doch wordt volstaan met de voorspelling van een wisselwerking.

Tenslotte kan nog worden opgemerkt dat de reikwijdte van de uitspraken over de relaties wordt bepaald door de konditie, dat het model geldt voor geindustrialiseerde samenlevingen met een sterk ontwikkelde arbeidsverdeling ( $\$$ 5.3.2). Rekening houdend met de inhoud van de normen op grond waarvan gedragingen voor registratie in aanmerking komen en die in dit model als een konstante wordt beschouwd ( $\$ 4.3$ ), moet de konditie waaronder het model geldigheid bezit nader worden gepreciseerd: de reikwijdte van de uitspraken in dit model beperkt zich tot westerse, geindustrialiseerde samenlevingen met een van oorsprong judeo-christelijke, humanitaire kultuur en een ver-ontwikkelde arbeidsverdeling.

\subsection{De proposities}

Het conceptuele model kan in 14 proposities worden samengevat. De proposities 1 tot en met 9 hebben betrekking op de 
onderlinge samenhangen van de verklarende verschijnselen, de proposities 10 tot en met 14 betreffen de effekten van deze verklarende verschijnselen op de spreiding van verschillende typen van afwijkend gedrag.

Propositie 1:

Het sociale volume en de fysieke dichtheid hebben geen effekt van betekenis op de arbeidsverdeling van gemeenschap.

In een samenleving met een relatief hoog ontwikkeld systeem van arbeidsverdeling zal de verdere ontwikkeling en spreiding van de arbeidsverdeling vooral worden bepaald door aan dit systeem inherente eigenschappen en mechanismen en zullen de effekten van het sociale volume en de fysieke dichtheid relatief gering zijn.

Propositie 2:

Het sociale volume heeft een direkt, door de fysieke dichtheid versterkt, effekt op het aantal dan wel de omvang van de in de gemeenschap aanwezige professionele instanties tot opsporing, behandeling of korrektie van storend en illegitiem gedrag.

Naarmate het sociale volume toeneemt zullen, vanwege de afnemende onderlinge kontrole op het handelen, de behoefte aan gespecialiseerde instrumenten tot beheersing van het gedrag groter en derhalve de professionele kontrole instanties talrijker dan wel omvangrijker zijn. In geval van ook een grotere fysieke dichtheid zullen, vanwege een relatief geringere intensiteit van de interakties, deze negatieve effekten van het sociale volume op de onderlinge gedragskontrole en dus ook de positieve effekten op de professionele instanties sterker zijn.

Propositie 3:

De fysieke dichtheid heeft een direkt, door het sociale volume gekonditioneerd, effekt op het aantal.dan wel de omvang van de in de gemeenschap aanwezige professionele instanties tot opsporing, behandeling of korrektie van storend en illegitiem gedrag.

Naarmate het sociale volume groter is, zal een toenemende fysieke dichtheid, vanwege de relatief geringere intensiteit van de interaktie en een geringere onderlinge kontrole op het handelen, gepaard gaan met een 
grotere behoefte aan gespecialiseerde instrumenten tot beheersing van het gedrag en zal derhalve het aantal dan wel de omvang van de professionele kontrole instanties groter zijn. Naarmate het sociale volume geringer is, zal dit effekt van de fysieke dichtheid op de professionele kontrole instanties, vanwege een relatief grotere intensiteit van de interakties en een striktere kontrole op het handelen, van minder betekenis zijn of mogelijk zelfs in zijn tegendeel verkeren.

\section{Propositie 4:}

De arbeidsverdeling heeft een direkt effekt op het aantal dan wel de omvang van de in de gemeenschap aanwezige professionele instanties tot opsporing, behandeling of korrektie van storend en illegitiem gedrag.

Naarmate door een toenemende differentiëring en specialisering van taken en funkties de noodzaak tot regulatie en koördinatie toeneemt, zal ook de behoefte aan gespecialiseerde instrumenten tot regulering en beheersing van het gedrag groter en derhalve de professionele kontrole instanties talrijker dan wel omvangrijker zijn.

\section{Propositie 5:}

Er is een direkte samenhang tussen het aantal of de omvang van de professionele instanties tot opsporing, behandeling en korrektie van storend en illegitiem gedrag en het opleidingsniveau van de gemeenschap.

Vanwege de behoefte aan gespecialiseerd en relatief hooggeschoold personeel zal een toenemend aantal dan wel een grotere omvang van de professionele kontrole instanties gepaard gaan met een hoger opleidingsniveau.

Propositie 6:

Het sociale volume heeft een direkt effekt op het opleidingsniveau van de gemeenschap.

Naarmate het sociale volume toeneemt, zullen vanwege de daarmee gepaard gaande ontwikkeling van bestuurlijke, administratieve en verzorgende funkties en de concentratie van opleidingsinstituten zowel de behoefte aan als de mogelijkheden tot een hogere scholing groter en derhalve het opleidingsniveau hoger zijn. 
Propositie 7 :

Er is een direkte samenhang tussen de arbeidsverdeling en het opleidingsniveau van de gemeenschap.

Vanwege de behoefte aan een relatief hooggeschoolde beroepsbevolking zullen een toenemende differentiëring van taken en funkties gepaard gaan met een hoger opleidingsniveau.

Propositie 8:

De arbeidsverdeling heeft een direkt effekt op de normatieve integratie van de gemeenschap.

Naarmate de differentiëring en specialisering van taken en funkties toenemen zal, vanwege de daaruit voortvloeiende sociale en kulturele heterogeniteit, de normatieve integratie verzwakken.

\section{Propositie 9 :}

Er is een direkte samenhang tussen het opleidingsniveau en de normatieve integratie van de gemeenschap.

Vanwege de wisselwerking tussen de behoefte aan en de vrijheid tot het verwerven van kennis, de individuele mondigheid enerzijds en het gezag en de bruikbaarheid van traditionele waarden en zekerheden anderzijds zal een stijgend opleidingsniveau gepaard gaan met een toenemende verzwakking van de normatieve integratie.

Propositie 10:

Het sociale volume heeft een, door de fysieke dichtheid versterkt, effekt op de variabiliteit van het gedrag in de gemeenschap.

Naarmate het sociale volume toeneemt, zal de mogelijkheid tot kontrole op het gedrag geringer en daarmee de vrijheid van handelen groter zijn en zullen derhalve legitieme, zelfgerichte alsook niet-agressieve, maar wel illegitieme gedragswijzen vaker, doch agressieve, op anderen gerichte gedragsreakties minder vaak voorkomen.

In geval van ook een grotere fysieke dichtheid, zullen vanwege de afnemende intensiteit van de interaktie de belangstelling voor alsook de mogelijkheid tot kontrole op het gedrag van anderen geringer zijn en 
zullen derhalve de effekten van het sociale volume op de onderscheiden gedragsreakties sterker zijn.

\section{Propositie 11:}

De fysieke dichtheid heeft een direkt, door het sociale volume gekonditioneerd effekt op de variabiliteit van het gedrag in de gemeenschap.

Naarmate, in geval van een gering sociaal volume, de fysieke dichtheid toeneemt, zal de intensiteit van de interaktie sterker en daarmee de belangstelling voor alsook de mogelijkheid tot kontrole op het gedrag van anderen groter en dus de vrijheid van handelen beperkter en de kans op ontdekking groter zijn en zullen derhalve agressieve, op anderen gerichte gedragsreakties vaker, doch legitieme, zelf-gerichte, alsook niet-agressieve, maar wel illegitieme gedragswijzen minder vaak voorkomen. Naarmate het sociale volume groter is, zullen vanwege een afnemende intensiteit van de interaktie, een geringere belangsteliing voor alsook mogelijkheid tot kontrole op het gedrag van anderen, deze effekten van de fysieke dichtheid op de onderscheiden gedragsreakties geringer zijn of mogelijk zelfs in hun tegendeel verkeren.

\section{Propositie 12:}

De professionele instanties tot opsporing, behandeling en korrektie van storend en illegitiem gedrag hebben een direkt effekt op de geregistreerde frekwenties van storend en van illegitiem gedrag in de gemeenschap.

Naarmate het aantal of de omvang van de professionele kontrole instanties toeneemt, zal meer storend of illegitiem gedrag worden opgespoord en behandeld en zullen derhalve de bekend geworden en geregistreerde frekwenties van elk van de onderscheiden gedragsreakties hoger zijn.

Propositie 13:

De normatieve integratie heeft een direkt effekt op de variabiliteit van het gedrag in de gemeenschap.

Naarmate de normatieve integratie verzwakt, zal de morele vrijheid van handelen toenemen en zullen derhalve legitieme, zelf-gerichte gedragswijzen vaker en illegitieme, op anderen gerichte agressieve gedragsreakties minder vaak voorkomen. 
Propositie 14:

Het effekt van de normatieve integratie op de variabiliteit van het gedrag in de gemeenschap wordt beĩnvloed door de mate van normatieve integratie van de samenleving.

In een samenleving met een relatief hoge mate van arbeidsverdeling, een relatief zwakke normatieve integratie en een ver-ontwikkeld transport- en kommunikatiesysteem, zijn de lokale gemeenschappen onderhevig aan een voor de samenleving als geheel geldende tendens tot een toenemende variabiliteit van het gedrag, welke de relatie tussen de normatieve integratie en legitieme en zelf-gerichte gedragswijzen zal versterken, doch de relatie tussen de normatieve integratie en illegitieme, op anderen gerichte, agressieve gedragsreakties zal verzwakken. 
7 OPERATIONALISERING VAN HET MODEL - INDIKATOREN EN HYPOTHESEN

Voor de operationalisering en toetsing van het model werd geput uit de gegevens, die eerder voor het 'gemeentekenmerkenonderzoek' waren verzameld.

Dit leverde voor de keuze van de indikatoren geen bijzondere problemen op. Het betekende echter wel, dat de geponeerde relaties niet als een in de tijd verlopend proces werden onderzocht: voor zowel de afhankelijke als de onafhankelijke variabelen zijn de gegevens over één en ook dezelfde tijdsperiode verzameld. Evenals in het onderzoek van Webb hebben de samenhangen van het operationele model dus betrekking op verschillen in de ruimtelijke spreiding van de verschijnselen, waarbij de korrespondentie met zich in de tijd voordoende verschillen wordt verondersteld.

In het nu volgende zullen eerst de variabelen worden besproken, die als correlaten van de concepten werden gekozen en vervolgens zullen de proposities van het conceptuele model worden vertaald in de hypothesen van het operationele model.

\subsection{De keuze van de indikatoren}

De keuze van de faktoren vluchtgedrag en agressief gedrag als de indikatoren voor de kriteriumconcepten van het model behoeft weinig betoog. (Evenzo zal duidelijk zijn, dat de faktor vatbaarheid met geen van de concepten van het model korrespondeert). Alleen al de verscheidenheid aan hoogladende variabelen bestempelt de faktor vluchtgedrag tot indikator voor een relatief hoge mate van variabiliteit van het gedrag, waarbij de negatieve ladingen van de variabelen index agressieve misdrijven en sterfte verkeersongevallen (Porterfield, 1960) het niet-agressieve karakter van deze gedragsdimensie aangeven ( $\$ 2.4$ tabel 5). Van de overige hoogladende variabelen zijn echtscheidingen, (laag) huwelijksgeboortecijfer en niet-uitgebrachte stemmen op te vatten als voorbeelden van legitieme gedragswijzen, die in het verleden de kollektiviteit plachten te schokken en kunnen schizofrenie, neurosen, alsook psychosen en zelfmoord als voorbeelden van zelf-gerichte gedragsreakties worden beschouwd. Met de hoge ladingen van met name de variabelen vermogensmisdrijven, sexuele misdrijven, agressieve misdrijven en ongeldig en blanko uitgebrachte stemmen vormt de faktor agressief gedrag een voor de hand liggende indikator voor de illegitieme, agressieve op anderen gerichte gedragsreaktie. 
Daarbij zijn de agressieve misdrijven en de ongeldig en blanko uitgebrachte stemmen als meer specifieke indikatoren voor het agressieve aspekt en de vermogensmisdrijven als een meer specifieke indikator voor het illegitieme, doch nietagressieve aspekt van de gedragskomponent te beschouwen. Dit onderscheid is van belang in verband met de proposities 10 en 11, waarin wat betreft het sociale volume en de fysieke dichtheid voor de legitieme, de zelf-gerichte en de illegitieme, niet-agressieve gedragswijzen gelijke effekten, doch voor de op anderen gerichte agressieve gedragswijzen verschillende effekten worden verondersteld. Om deze uitspraken te kunnen toetsen zijn, behalve de faktoren vluchtgedrag en agressief gedrag, ook de variabelen echtscheiding en zelfmoord en de variabelen vermogensmisdrijven en agressieve misdrijven als kriteriumvariabelen van het operationele model gekozen.

De normatieve integratie, opgevat als de op morele concensus gebaseerde sociale cohesie van de gemeenschap, is met de beschikbare geregistreerde gegevens niet op direkte wijze te indiceren.

Dit concept wordt daarom geoperationaliseerd met een aantal wel meetbare gemeenschapskenmerken, die blijkens uitspraken van Durkheim fungeren als kondities voor de geldigheid, homogeniteit en reikwijdte van het kollektieve geweten.

Deze kondities betreffen a) de binding aan de lokale gemeenschap, van belang voor de duurzaamheid en de intensiteit van de sociale relaties en, zoals Durkheim (1965) benadrukt, voor de overdracht en het gezag van 'traditional beliefs and practices', b) de verscheidenheid aan sociale groeperingen, van belang vanwege de homogeniteit of heterogeniteit van gedragscodes, doelstellingen en belangen en c) de binding aan godsdienstige dogma's en gebruiken, hier vooral gezien als bepalend voor de mate van 'moral restraint' op de zelfstandigheid van denken en handelen.

Aangenomen wordt dat een gemeenschap met een overwegend autochtone bevolking, een weinig gedifferentiëerde sociale gelaagdheid en een hoge mate van kerkelijkheid ook wordt gekenmerkt door een hoge mate van normatieve integratie. Als indikatoren voor deze kondities zijn gekozen het percentage autochtone bevoiking, de diversiteitscoëfficiënt sociale beroepsgroepen (Bijlage $V$, tabel $V-4$ ) en het percentage onkerkelijke bevolking (respektievelijk de onafhankelijke variabelen 27, 32, en 61 in Bijlage II).

Met de sociale beroepsgroepen, zoals onderscheiden door het 
C.B.S. I) wordt in feite meer een differentiatie naar sociaal prestige dan naar beroepen weergegeven. In dit opzicht biedt deze verdeling naar sociale beroepsgroepen een indikatie voor de sociale gelaagdheid in de gemeente. Bij de berekening van de hier gebruikte diversiteitscoëfficiënt wordt uitgegaan van de waarschijnlijkheid, dat leden van een populatie bij onderlinge vergelijking ('pairing') dezelfde dan wel verschillende eigenschappen vertonen ten aanzien van de variabele, waarvoor men de diversiteit van de populatie wil meten (Lieberson, 1969). De coëfficiënt geeft de proportie weer van met elkaar vergeleken leden van de populatie ('pairs') met dezelfde eigenschappen -in dit geval dus de proportie van de mannelijke hoofden van huishoudens die tot dezelfde sociale beroepsgroepen behoren- en wordt berekend volgens $\Sigma x_{i}{ }^{2}$, waarbij $x_{i}=$ de proportie van de tot een bepaalde sociale beroepsigroep behorende mannelijke hoofden van huishoudens ten opzichte van het aantal mannelijke hoofden van huishoudens in de gemeente.

De eenzijdigheid naar sociale beroepsgroepen is groter naarmate de diversiteitscoëfficiënt hoger is. De hoogst mogelijke waarde is 1.00 (het totale aantal mannelijke hoofden van huishoudens in de gemeente behoort tot een en dezelfde beroepsgroepl, terwijl de laagst mogelijke waarde wordt bepaald door het aantal groepen of categorieën waarover de coëfficiënt wordt berekend.

Aangezien er tien sociale beroepsgroepen worden onderscheiden is bij maximale heterogeniteit deze laagste waarde $10(1.00 / 10)^{2}=.10$.

$\mathrm{Na}$ omscoring van het \% onkerkelijken zijn deze drie variabelen door middel van optelling van hun klassescores samengevoegd tot de index normatieve integratie (maximale spreidingsbreedte 3-27, feitelijke spreidingsbreedte 5-26), waarbij een hoge score staat voor een relatief hoge mate van normatieve integratie.

Voor de operationalisering van de professionele instanties tot opsporing, behandeling en korrektie van storend of illegitiem gedrag is gebruik gemaakt van de gegevens betreffende de zogenaamde 'cijfersproducerende' in-

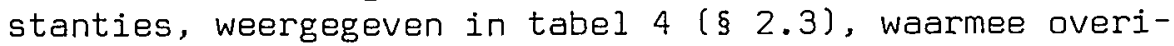
gens de bestaande verscheidenheid aan kantrolerende en behandelende instanties onvolledig en eenzijdig wordt gemeten -behalve de politiesterkte betreffen alle gegevens de aanwezigheid of omvang van medische voor- 
zieningen. De keuze van deze variabelen impliceert dus de, vanwege het gebrek aan bruikbare, aanvullende gegevens (Drop, 1971), niet-verifieerbare veronderstelling, dat aantal of omvang van deze voorzieningen indikatief zijn voor aantal of omvang van de in het model bedoelde professionele instanties.

Door optelling van hun klassenscores zijn de variabelen politiesterkte, beschikbare ziekenhuisbeddagen, huisartsendichtheid, wijkverpleegsters, vroedvrouwen en afstand van de gemeente tot de dichtstbijzijnde psychiatrische inrichting (respektievelijk de variabelen 'cijfersproducerende' instanties $1,2,3,5,6$ en 7 in bijlage II) samengevoegd tot de index cijfersproducerende instanties (maximale spreidingsbreedte 5-46, feitelijke spreidingsbreedte 12-37).

Vanwege de veronderstelde relatie met de arbeidsverdeling wordt het opleidingsniveau van de gemeenschap geoperationaliseerd als het opleidingsniveau van de beroepsbevolking. waarvoor het percentage beroepsbevolking met meer dan alleen lager onderwijs, als indikator is gebruikt. (Onafhankelijke variabele 62 in Bijlage IIJ.

Evenals in Webb's onderzoek wordt de arbeidsverdeling opgevat als de eenzijdigheid dan wel verscheidenheid van de economische struktuur -door Webb geoperationaliseerd met de spreiding van de beroepsbevolking over de bedrijfstakken ( 5 5.2). Op grond van de overweging, dat de economische struktuur niet alleen wordt bepaald door de verscheidenheid aan bedrijfstakken, maar ook door de differentiatie van de bedrijfsklassen binnen de bedrijfstakken (Steigenga, 1955), wordt de mate van arbeidsverdeling geoperationaliseerd met zowel de diversiteitscoëfficiënt bedrijfstakken ${ }^{2}$ ) als het percentage beroepsbevolking werkzaam in de vijf belangrijkste bedrijfsklassen ${ }^{3}$ ) (Bijlage $V$, tabel $V-3$, onafhankelijke variabelen 16 en 17 in Bijlage IIJ.

Beide variabelen werden zo berekend, dat een hoge score indikatief was voor een relatief eenzijdige economische struktuur.

Ondat in de desbetreffende proposities sprake is van een toenemende arbeidsverdeling zijn beide variabelen omgescoord en vervolgens door optelling van hun klassenscores gekombineerd tot de index economische diversiteit (maximale spreidingsbreedte 2-18, feitelijke spreidingsbreedte 3-18), waarbij een hogere score dus staat voor een hogere mate van economische verscheidenheid. 
Het sociale volume en de fysieke dichtheid tenslotte zijn geindiceerd met respektievelijk het aantal inwoners en de bevolkingsdichtheid (onafhankelijke variabelen 1 en 2 in Bijlage II).

Wat betreft de geldigheid, vitgedrukt in de proportie systematische foutenvariantie ten opzichte van de totale variantie ontbreekt voor de onafhankelijke variabelen, waarvoor de gegevens overwegend afkomstig zijn van het C.B.S., de noodzakelijke informatie om steekhoudende uitspraken te kunnen doen over een eventuele systematische vertekening van de gepresenteerde frekwenties.

Ditzelfde geldt ook voor de betrouwbaarheid van deze variabelen, opgevat als de proportie toevallige variantie (ruis), veroorzaakt door eigenschappen van het meetinstrument. Hoewel er ongetwijfeld voor alle gegevens sprake zal zijn van vergissingen en inkonsistenties, is het onmogelijk te schatten in welke mate dit het geval is. Evenmin kan worden bepaald of en in welke mate de variabelen aangaande hun betrouwbaarheid van elkaar verschillen. Vanwege de werkwijze en de outillage van het C.B.S. is misschien de kans op meetfouten voor de gegevens die van deze instelling afkomstig zijn, geringer dan voor de gegevens die van partikuliere instanties werden verkregen. Aan de betrouwbarheid en geldigheid van de gedragsvariabelen werd eerder, in paragraaf 2.3 al aandacht besteed. Hierbij werden de variabelen echtscheidingen, vermogensmisdrijven en agressieve misdrijven gerekend tot de geldigheidskategorie waarvoor inderdaad sprake is van een relatief grotere kans op systematische fouten (tabel 3). In dit verband is het van belang op te merken dat voor de echtscheidingen deze kwalifikatie betrekking had op de betekenis van deze variabele als indikator voor de proportie min of meer ernstig ontwrichte huwelijken in de gemeente. Aangezien de variabele echtscheidingen in dit model echter niet als indikator voor huwelijksinstabiliteit, maar als een vorm van legitiem, zelfgericht gedrag is opgenomen, doet dit geldigheidsprobleem zich hier niet voor. De twijfel aan de geldigheid van de variabelen vermogensmisdrijven en agressieve misdrijven tieeft voor een belangrijk deel te maken met de systematische beĩnvloeding van de geregistreerde frekwenties door ondermeer de aktiviteiten van de politie. Op dit aspekt van het geldigheidsprobleem wordt in het model door middel van de voorspelde effekten van de index cijfersproducerende instanties gekontroleerd. 


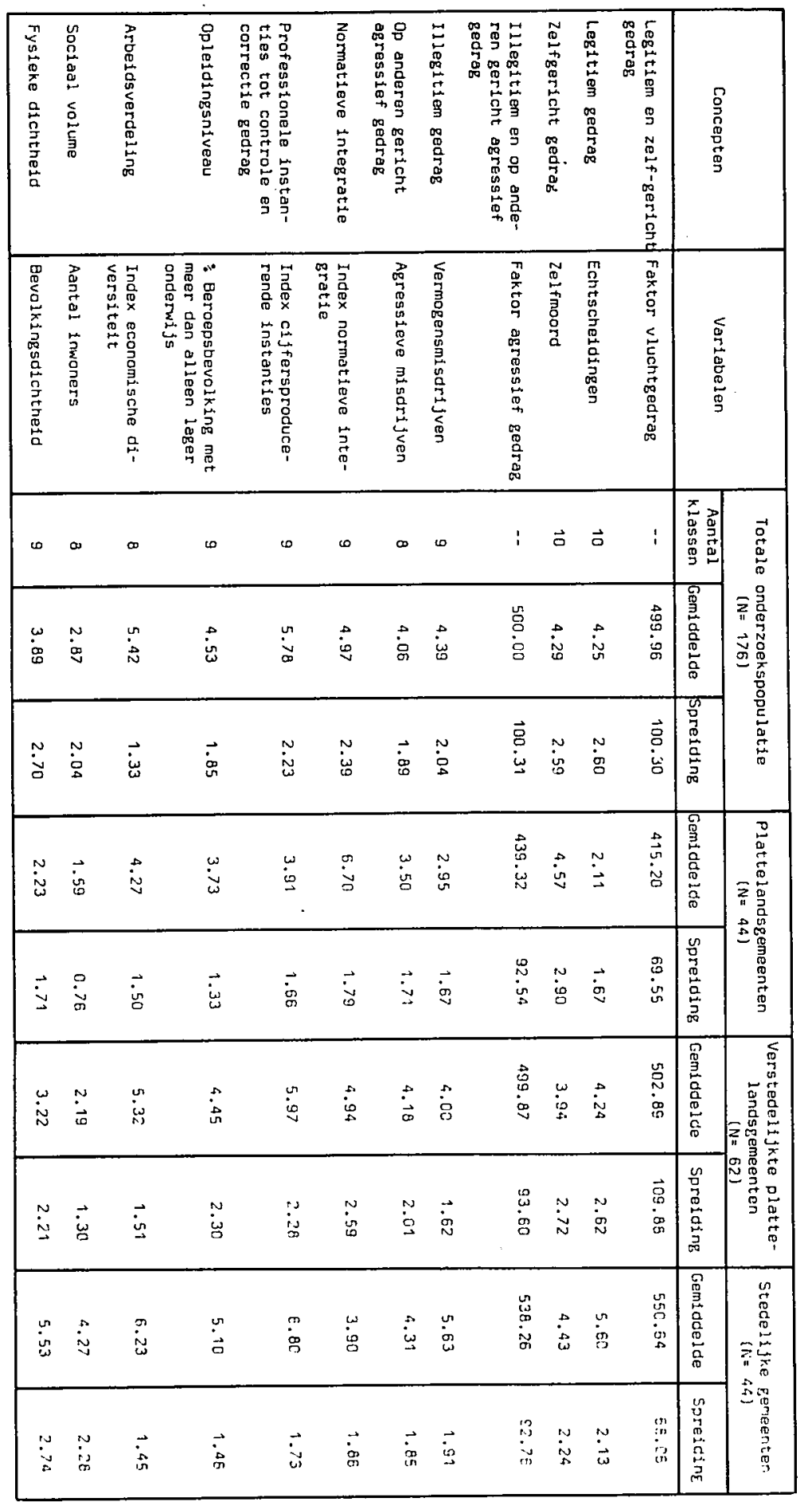


Bij de eigen verwerking van de verzamelde gegevens werden alle, door drie codeurs op ponsslips overgebrachte coderingen gekantroleerd. Bepaalde ponsfouten werden met behulp van de computer gekontroleerd. De verhoudingscijfers werden door de computer berekend.

De variabelen van het operationele model zijn samengevat in tabel 8.

Met uitzondering van de redelijk normale verdelingen van de faktor vluchtgedrag en agressief gedrag, zijn de frekwentieverdelingen van de variabelen getransformeerd tot indelingen in gelijke intervalsklassen, waarbij de extreme waarden in open klassen zijn samengenomen.

De gemiddelden en spreidingen zijn op de scores van deze klasse-indelingen berekend.

\subsection{De hypothesen}

De relaties tussen de variabelen, die als correlaten van de concepten van het model werden gekozen, kunnen als volgt in schema worden gebracht:

Schema 2:

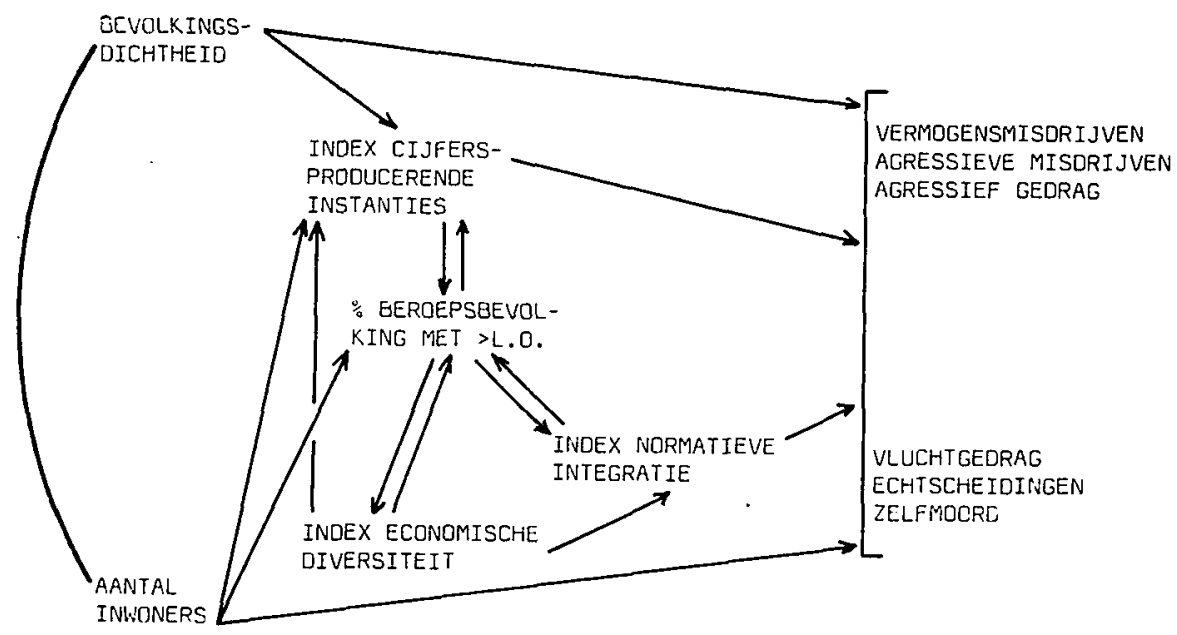

Met deze operatịonalisering van het model kunnen nu de proposities worden vertaald in de volgende hypothesen. 
Hypothese 1:

Het aantal inwoners en de bevolkingsdichtheid correleren niet of nauwelijks met de index economische diversiteit.

Hypothese 2:

a. Het aantal inwoners correleert positief met de index cijfersproducerende instanties.

b. De positieve correlatie van het aantal inwoners met de index cijferspraducerende instanties is in geval van een relatief grote bevolkingsdichtheid -in casu de urbanisatiegraadcategorie stedelijke gemeenten- sterker dan bij een relatief geringe bevolkingsdichtheid -in casu de urbanisatiegraadcategorie plattelandsgemeenten.

Hypothese 3 :

a. In geval van een relatief groot aantal inwoners -in casu de urbanisatiegraadcategorie stedelijke gemeentencorreleert de bevalkingsdichtheid positief met de index cijfersproducerende instanties.

b. In geval van een relatief gering aantal inwoners -in casu de urbanisatiegraadcategorie plattelandsgemeentenis de correlatie van de bevolkingsdichtheid met de index cijfersproducerende instanties van weinig betekenis meer dan wel tegengesteld van richting.

Hypothese 4:

De index economische diversiteit correleert positief met de index cijfersproducerende instanties.

Hypothese 5:

De index cijfersproducerende instanties correleert positief met het percentage beroepsbevolking met meer dan lager onderwijs.

Hypothese 6:

Het aantal inwoners correleert positief met het percentage beroepsbevolking met meer dan lager onderwijs.

Hypothese 7:

De index economische diversiteit correleert positief met het percentage beroepsbevolking met meer dan lager onderwijs. 
Hypothese 8:

De index economische diversiteit correleert negatief met

de index normatieve integratie.

Hypothese 9:

Het percentage beroepsbevolking met meer dan lager onderwijs correleert negatief met de index normatieve integratie.

Hypothese 10:

a. Het aantal inwoners heeft een positief effekt op de faktor vluchtgedrag en de variabelen echtscheidingen, zelfmoord en vermogensmisdrijven en een negatief effekt op de variabele agressieve misdrijuen. Het effekt op de faktor agressief gedrag is niet te voorspellen.

b. De effekten van het aantal inwoners op de gedragsvariabelen zijn in geval van een relatief grote bevolkingsdichtheid -in casu de urbanisatiegraadcategorie stedelijke gemeenten- sterker dan bij een relatief geringe bevolkingsdichtheid -in casu de urbanisatiegraadcategorie plattelandsgemeenten.

Hypothese 11:

a. In geval van een relatief gering aantal inwoners -in casu de urbanisatiegraadcategorie plattelandsgemeenten- heeft de bevolkingsdichtheid een negatief effekt op de faktor vluchtgedrag en de variabelen echtscheidingen, zelfmoord en vermogensmisdrijven en een positief effekt op de variabele agressieve misdrijven. Het effekt op de faktor agressief gedrag is niet te voorspellen.

b. In geval van een relatief groot aantal inwaners -in casu de urbanisatiegraadcategorie stedelijke gemeenten- zijn de effekten van de bevolkingsdichtheid op de gedragsvariabelen van weinig betekenis meer dan wel tegengesteld van richting.

Hypothese 12:

De index cijfersproducerende instanties heeft een positief effekt op elk van de onderscheiden gedragsvariabelen.

Hypothesen 13:

De index normatieve integratie heeft een negatief effekt op de faktor vluchtgedrag en de variabelen echtscheidingen 
en zelfmoord en een positief effekt op de faktor agressief gedrag en de variabelen vermogensmisdrijven en agressieve misdrijuen.

Hypothese 14:

Het negatieve effekt van de index normatieve integratie op de faktor vluchtgedrag en de variabelen echtscheidingen en zelfmoord is sterker dan het positieve effekt op de faktor agressief gedrag en de variabelen vermogensmisdrijven en agressieve misdrijuen.

Voor zover het de theorie van Durkheim aangaat, zijn de hypothesen 8 en 13 als de centrale veronderstellingen van het model te beschouwen.

\subsection{De toetsingsprocedure}

De hypothesen zijn getoetst op de totale onderzoekspopulatie van 176 gemeenten. De resultaten worden dus ook voor de totale onderzoekspopulatie berekend en weergegeven.

Dat daarnaast toch ook de analyseresultaten voor de urbanisatiegraadcategorieën plattelandsgemeenten en stedelijke gemeenten worden gegeven, berust op twee gronden:

- de toetsing van de hypothesen $2^{b}, 3^{b}, 10^{b}$, en $11^{b}$, waarin voor de beide urbanisatiegraadcategorieën verschillende effekten van de variabelen aantal inwoners en bevolkingsdichtheid op achtereenvolgens de index cijfersproducerende instanties en de gedragsvariabelen worden verondersteld.

- de toetsing van Webb's veronderstelling Jat de geponeerde relaties worden gekonditioneerd door de, met de gemeentegrootte samenhangende, variantie van de variabelen.

Zoals uit tabel 8 kan worden afgeleid vertegenwoordigen de beide urbanisatiegraadcategorieën wat betreft het inwonertal een beperking naar beide extremen van de frekwentieverdeling: de plattelandsgemeenten kenmerken zich door een gemiddeld relatief klein aantal inwoners, terwijl de categorie stedelijke gemeenten vooral de grotere gemeenten omvat. Met de per urbanisatiegraadcategorie afzonderlijk berekende correlaties kan worden nagegaan of de samenhangen tussen de variabelen al dan niet door de gemeentegrootte worden gekonditioneerd. 
Deze redenen zijn niet van toepassing op de verstedelijkte plattelandsgemeenten. Bovendien kenmerkt deze urbanisatiegraadcategorie zich door een bijzondere samenstelling: de welvarende forensengemeenten (subcategorie B 3 ) en de industriegemeenten (subcategorieën B 1 en B 2). De heterogeen samengestelde categorie verstedelijkte plattelandsgemeenten is daarom niet afzonderlijk bij de analyse betrokken. De toetsing is in twee gedeelten uitgevoerd. voor de analyse van de onderlinge samenhangen van de onafhankelijke, verklarende variabelen van het model (hypothesen 1 tot en met 9 ), is gebruik gemaakt van de multivariate techniek van de partiële correlatie.

Voor deze samenhangen zijn partiële correlaties van de vierde orde berekend: de coëfficiënten geven de correlaties tussen telkens twee variabelen met uitschakeling van de invloed van de vier overige onafhankelijke variabelen. De resultaten worden besproken in hoofdstuk 8 -de volledige matrices van de nulde orde en van de vierde orde correlaties zijn weergegeven in bijlage VIII.

De effekten van de onafhankelijke variabelen van het model op de gedragsvariabelen (hypothesen 10 tot en met 14) zijn onderzocht met behulp van een, op de nulde orde correlaties (bijlage IX) uitgevoerde, multiple regressieanalyse.

Met deze analyse zijn per gedragsvariabele de afzonderlijke, niet meer tot hun onderlinge samenhangen te herleiden, effekten van de onafhankelijke variabelen vastgesteld. Bovendien is voor elk van de gedragsvariabelen, middels de berekening van multiple correlatiecoëfficiënten en de daarvan afgeleide percentages verklaarde variantie ook het gezamenlijke effekt van de verklarende variabelen bepaald.

De uitkomsten van deze analyse worden besproken in hoofdstuk 9. 
8 TOETSING VAN HET MODEL I: DE RELATIES TUSSEN DE ONAFHANKELIJKE VARIABELEN VAN HET MODEL

In dit hoofdstuk worden de toetsingsresultaten voor de hypothesen 1 tot en met 9 vermeld. Daarbij wordt volstaan met een korte weergave van de analyse-uitkomsten. De betekenis en konsekwenties van de toetsingsresultaten voor het conceptuele model zullen, tesamen met die voor de afhankelijke variabelen, worden besproken in hoofdstuk 10.

De resultaten worden gepresenteerd in een viertal tabellen, waarin zowel de totale, nulde orde als de partiële, vierde orde correlaties zijn weergegeven. Ter wille van de overzichtelijkheid zullen per tabel steeds de bijbehorende hypothesen worden uitgeschreven.

\subsection{Resultaten hypothese 1}

Hypothese 1: Het aantal inwoners en de bevolkingsdichtheid correleren niet of nauwelijks met de index economische diversiteit.

De toetsingsresultaten voor deze hypothese staan hieronder vermeld in tabel 9 .

Tabel 9: Nulcie orde en vierde orde correlaties van het aantal inwoners en de bevolkingsdichtheid met de index economische diversiteit voor de totale onderzoekspopulatie en de urbanisatiegraadcategorieën plattelandsgemeenten en stedelijke gemeenten.

\begin{tabular}{|c|c|c|c|c|c|c|}
\hline \multirow{3}{*}{ Hypothese 1} & \multicolumn{6}{|c|}{ Index economische diversiteit } \\
\hline & \multicolumn{2}{|c|}{$\begin{array}{l}\text { Totaal aantal } \\
\text { gemeenten } \\
(N=176)\end{array}$} & \multicolumn{2}{|c|}{$\begin{array}{l}\text { Plattelands- } \\
\text { gemeenten } \\
(N=44)\end{array}$} & \multicolumn{2}{|c|}{$\begin{array}{l}\text { Stedelijke } \\
\text { gemeenten } \\
(N=70)\end{array}$} \\
\hline & $\begin{array}{c}r \\
\text { totaal }\end{array}$ & $\frac{r}{\text { partieel }}$ & $\begin{array}{c}\Gamma \\
\text { totaal }\end{array}$ & $\stackrel{r}{\text { partieel }}$ & $\begin{array}{c}r \\
\text { totaal }\end{array}$ & $\begin{array}{c}r \\
\text { partieel }\end{array}$ \\
\hline Aantal inwoners & .26 & .09 & -.05 & .01 & -.04 & -.10 \\
\hline Bevolkingsdichtheid & .24 & -.07 & .28 & .11 & .02 & .03 \\
\hline
\end{tabular}


In zowel de totale onderzoekspopulatie als de beide urbanisatiegraadcategorieën blijken het aantal inwoners en de bevolkingsdichtheid slechts zwak te correleren met de index economische diversiteit.

Voor het totale aantal gemeenten zijn de nulde orde correlaties (respectievelijk.26 en .24) na partialisering van weinig betekenis meer (respectievelijk .09 en -.07). Ditzelfde is binnen de categorie plattelandsgemeenten ook het geval voor de correlatie van de bevolkingsdichtheid met de index economische diversiteit: de correlatiecoëfficiënt daalt na partialisering van .28 tot .11. In deze urbanisatiegraadcategorie draagt het inwonertal voor noch na partialisering iets bij tot de verklaring van de verschillen in economische diversiteit. In de categorie stedelijke gemeenten geldt dit laatste voor zowel het inwonertal als de bevolkingsdichtheid.

Deze uitkomsten stemmen overeen met de verwachting: bij het gegeven niveau van economische ontwikkeling van de samenleving hebben het aantal inwoners en de bevolkingsdichtheid geen, van de overige bij het model betrokken variabelen onafhankelijk effekt van betekenis op de mate van economische diversiteit van de gemeenten.

Met deze konstatering kan tot de bevestiging van hypothese 1 worden gekonkludeerd.

\subsection{Resultaten hypothesen 2, 3, 4 en 5}

De uitkomsten voor de hypothesen 2 tot en met 5 betreffende de correlaten van de index cijfersproducerende instanties worden tesamen weergegeven in tabel 10. Wat de relaties van de index cijfersproducerende instanties met de variabelen inwonertal en bevolkingsdichtheid betreft werden aan het model de navolgende verwachtingen ontleend:

Hypothese 2: a. Het aantal inwoners correleert positief met de index cijfersproducerende instanties.

b. De positieve correlatie van het aantal inwoners met de index cijfersproducerende instanties is in geval van een relatief grote bevolkingsdichtheid -in casu in de categorie stedelijke gemeenten- sterker dan bij een relatief geringe bevolkingsdichtheid -in casu in de categorie plattelandsgemeenten. 
Hypothese 3: a. In geval van een relatief groot aantal inwoners - in casu de categorie stedelijke gemeenten- correleert de bevolkingsdichtheid positief met de index cijfersproducerende instanties.

b. In geval van een relatief gering aantal inwoners -in casu de categorie plattelandsgemeenten- is de correlatie van de bevolkingsdichtheid met de index cijfersproducerende instanties van weinig betekenis meer dan wel tegengesteld van richting.

Tabel 10. Nulde orde en vierde orde correlaties van het aantal inwoners, de bevolkingsdichtheid, de index economische diversiteit en het $\%$ beroepsbevolking met meer dan lager onderwijs met de index cijfersproducerende instanties voor de totale onderzoekspopulatie en de urbanisatiegraadcategorieën plattelandsgemeenten en stedelijke gemeenten.

\begin{tabular}{|c|c|c|c|c|c|c|}
\hline \multirow{3}{*}{$\begin{array}{l}\text { Hypothesen } \\
2,3,4 \text { en } 5\end{array}$} & \multicolumn{6}{|c|}{ Index cijfersproducerende instanties } \\
\hline & \multicolumn{2}{|c|}{$\begin{array}{l}\text { Totaal aantal } \\
\text { gemeenten } \\
(N=176)\end{array}$} & \multicolumn{2}{|c|}{$\begin{array}{l}\text { Plattelands- } \\
\text { gemeenten } \\
(N=44)\end{array}$} & \multicolumn{2}{|c|}{$\begin{array}{c}\text { Stedelijke } \\
\text { gemeenten } \\
(N=70)\end{array}$} \\
\hline & $\begin{array}{c}r \\
\text { totaal }\end{array}$ & $\frac{r}{\text { partieel }}$ & $\begin{array}{c}r \\
\text { totaal }\end{array}$ & $\stackrel{r}{\text { partieel }}$ & $\begin{array}{c}r \\
\text { totaal }\end{array}$ & $\begin{array}{c}r \\
\text { partieel }\end{array}$ \\
\hline Aantal inwoners & .38 & .07 & .10 & .09 & .27 & .10 \\
\hline Bevolkingsdichtheid & .45 & .24 & .20 & .21 & .28 & .13 \\
\hline $\begin{array}{l}\text { Index economische } \\
\text { diversiteit }\end{array}$ & .34 & .14 & .19 & .26 & -.03 & -.07 \\
\hline $\begin{array}{l}\% \text { Beroepsbevolking } \\
\text { met }>1.0 \text {. }\end{array}$ & .45 & .23 & .19 & .28 & .27 & .19 \\
\hline
\end{tabular}

Bij konstanthouding van de overige variabelen blijkt het inwonertal van de gemeenten op zich weinig invloed te hebgen op de aanwezigheid of omvang van de professionele hulpverlenende of gedragskorrigerende instanties.

Hoewel positief -dus in de verwachte richting- is de correlatie van het aantal inwoners met de index cijfersproducerende instanties na partialisering nogal laag: de correlatiecoëfficiënt daalt van .38 naar .07 . Binnen de categorieën plattelandsgemeenten en stedelijke gemeenten zijn de partiële 
correlaties niet veel hoger en tegen de verwachting in bovendien gelijk: respectievelijk .09 en . 10 .

Hypothese 2 wordt dus in haar geheel door de onderzoeksresultaten weersproken.

Anders dan het inwonertal heeft de bevolkingsdichtheid wel een onafhankelijk effekt op de index cijfersproducerende instanties, althans voor het totale aantal gemeenten. Hoewel niet bijzonder hoog, geeft de partiële correlatie voor de totale onderzoekspopulatie (.24) een tendens aan tot een concentratie van professionele hulpverlenende instanties in dichter bevolkte gemeenten.

Uit de partiële correlaties binnen de beide urbanisatiegraadcategorieën blijkt echter weinig van een konditionerende werking van het aantal inwoners op het effekt van de bevolkingsdichtheid. Weliswaar is in de categorie plattelandsgemeenten de positieve partiële correlatie tussen de bevolkingsdichtheid en de index cijfersproducerende instanties (.21) inderdaad niet al te hoog, de partiële correlatie in de categorie stedelijke gemeenten is echter na partialisering beduidend lager (.13).

Beide uitkomsten in aanmerking genomen moet hypothese 3 als verworpen worden beschouwd.

De hypothesen over de relaties van de index cijfersproducerende instanties met achtereenvolgens de index economische diversiteit en het percentage beroepsbevolking met meer dan lager onderwijs luiden:

Hypothese 4: De index economische diversiteit correleert positief met de index cijfersproducerende instanties.

Hypothese 5: De index cijfersproducerende instanties correleert positief met het percentage beroepsbevolking met $>1.0$.

Na partialisering heeft, berekend over de totale onderzoekspopulatie, de index economische diversiteit slechts een gering positief effekt op de index cijfersproducerende instanties $(r=.14)$. Binnen de categorie plattelandsgemeenten is dit effekt wat sterker $(r=.26)$, bij de stedelijke gemeenten ontbreekt de samenhang evenwel: zowel voor als na partialisering is de correlatie negatief en te laag om van enige betekenis te zijn (respectievelijk -.03 en -.07). Het percentage beroepsbevolking met $>1.0$. tenslotte, correleert overeenkomstig de verwachting positief met de index 
cijfersproducerende instanties.

Hoewel de samenhang niet bijzonder sterk is -voor de totale onderzoekspopulatie, de plattelandsgemeenten en de stedelijke gemeenten zijn de partiële correlaties achtereenvolgens .23, .28 en .19- is er toch sprake van een tendens tot concen-. tratie van professionele gedragsbewakende instanties in gemeenten met een hoger geschoolde beroepsbevolking. Gelet ap de uitkomsten voor de totale onderzoekspopulatie worden strikt genomen de hypothesen 4 en 5 weliswaar bevestigd, maar gezien de lage partiële correlaties moet toch tot een slechts geringe onafhankelijke bijdrage van de index economische diversiteit en van het percentage beroepsbevolking met $>1.0$. tot de verklaring van de verschillen in aanwezigheid en omvang van de professionele hulpverlenende instanties worden gekonkludeerd.

\subsection{Resultaten hypothesen 6 en 7}

Hypothese 6: Het aantal inwoners correleert positief met het percentage beroepsbevolking met $>1.0$.

Hypothese 7: De index economische diversiteit correleert positief met het percentage beroepsbevolking met $>1.0$.

De analyse-uitkomsten voor deze hypothesen worden gegeven in tabel 11.

Tabel 11: Nulde orde en vierde orde correlaties van het aental inwoners, de index economische diversiteit en de bevolkingsuichtheid met het \% beroepsbevolking met meer dan lager onderwijs voor de totale onderzoekspopulatie en de urbanisatiegraadcategorieën plattelandsgemeenten en stedelijke gemeenten.

\begin{tabular}{|c|c|c|c|c|c|c|}
\hline \multirow{3}{*}{$\begin{array}{l}\text { Hypothesen } \\
6 \text { en } 7\end{array}$} & \multicolumn{6}{|c|}{$\%$ Beroepsbevolking met $>1.0$. } \\
\hline & \multicolumn{2}{|c|}{$\begin{array}{c}\text { Totaal aantal } \\
\text { gemeenten } \\
(N=1>6)\end{array}$} & \multicolumn{2}{|c|}{$\begin{array}{l}\text { Plattelands- } \\
\text { gemeenten } \\
(N=44)\end{array}$} & \multicolumn{2}{|c|}{$\begin{array}{c}\text { Stedelijke } \\
\text { gemeenten } \\
(N=70)\end{array}$} \\
\hline & $\begin{array}{c}r \\
\text { totaal }\end{array}$ & $\begin{array}{c}r \\
\text { partieel }\end{array}$ & $\begin{array}{c}r \\
\text { totaal }\end{array}$ & $\begin{array}{c}r \\
\text { partieel }\end{array}$ & $\begin{array}{c}r \\
\text { totaal }\end{array}$ & $\begin{array}{c}r \\
\text { partieel }\end{array}$ \\
\hline Aantal inwoners & .38 & .18 & .09 & .06 & .32 & .17 \\
\hline $\begin{array}{l}\text { Index economische } \\
\text { diversiteit }\end{array}$ & .30 & -.13 & -.23 & -.28 & .26 & .02 \\
\hline bevolkingsdichtheid & .36 & -.02 & -.15 & -.15 & .31 & .13 \\
\hline
\end{tabular}


Wat betreft het aantal inwoners is er voor de totale onderzoekspopulatie na partialisering sprake van een bescheiden onafhankelijk positief effekt op het percentage beroepsbevolking met meer dan uitsiuitend lager onderwijs $(r=.18)$. Deze tendens is, gezien de partiële correlatie van .17, ook aanwezig in de categorie stedelijke gemeenten. Bij de plattelandsgemeenten echter ontbreekt deze samenhang vrijwel geheel $(r=.06)$-deze categorie gemeenten wordt in haar geheel gekenmerkt door een relatief laag opleidingsniveau van de beroepsbevolking (tabel 8), waarbij de grootte van de gemeente klaarblijkelijk weinig verschil maakt.

Ten aanzien van de bevolkingsdichtheid, waarvoor in het model geen relatie met het percentage beroepsbevolking wordt verondersteld, kan worden vastgesteld dat daarvan niet of nauwelijks invloed vitgaat op het scholingsniveau van de beroepsbevolking: voor het totale aantal gemeenten bedraagt de partiële correlatie -.02, voor de plattelands- en de stedelijke gemeenten zijn de partiële correlaties niet bijzonder veel hoger, respectievelijk -.15 en . 13.

De index economische diversiteit tenslotte blijkt in de totale onderzoekspopulatie zwak negatief samen te hangen met het percentage beroepsbevolking dat voortgezet onderwijs heeft gevolgd: de positieve nulde orde correlatie van .30 verandert na partialisering in een negatieve partiële correlatie van -.13. Tegen de verwachting in is er, na uitschakeling van de effekten van de overige variabelen, dus sprake van een tendens tot lagere percentages beroepsbevolking met een vervolgopleiding in geval van een grotere economische diversiteit. Dit geldt met name in de categorie plattelandsgemeenten -de reeds negatieve nulde orde correlatie stijgt na partialisering van -.23 tot -.28 .

Hieruit zou kunnen blijken dat niet zozeer de diversiteit van de economische aktiviteiten, maar misschien veelmeer de verbetering van de produktiviteit en van de kwaliteit, in dit geval dus in de agrarische bedrijfstak, gepaard gaan met een hoger opleidingsniveau van de beroepsbevalking. Bij de stedelijke gemeenten is de aanvankelijk positieve correlatie (.26) na partialisering van geen betekenis meer (.02).

Samenvattend kan gekonkludeerd worden, dat hypothese 6 steun vindt in de onderzoeksresultaten, zij het dan dat de correlatie minder sterk is dan eigenlijk werd verwacht, maar dat hypothese 7 door de analyse-uitkomsten wordt weersproken. 


\subsection{Resultaten hypothesen 8 en 9}

In tabel 12 worden de resultaten vermeld voor:

Hypothese 8: De index economische diversiteit correleert negatief met de index normatieve integratie.

Hypothese 9: Het percentage beroepsbevolking met $>1.0$. correleert negatief met de index normatieve integratie.

Tabel 12: Nulde orde en vierde orde correlaties van de index economische diversiteit, het : beroepsbevolking met meer dan lager onderwijs, de index cijfersproducerende instanties, het aantal inwoners en de bevolkingsdichtheid met de index normatieve integratie voor de totale onderzoekspopulatie en de urbanisatiegraadcategorieën plattelandsgemeenten en stedelijke gemeenten.

\begin{tabular}{|c|c|c|c|c|c|c|}
\hline \multirow{3}{*}{$\begin{array}{l}\text { Hypothesen } \\
8 \text { en } 9\end{array}$} & \multicolumn{6}{|c|}{ Index normatieve integratie } \\
\hline & \multicolumn{2}{|c|}{$\begin{array}{c}\text { Totaal aantal } \\
\text { Eeneenten } \\
(N=176)\end{array}$} & \multicolumn{2}{|c|}{$\begin{array}{l}\text { Plattelands- } \\
\text { gemeenten } \\
(N=44)\end{array}$} & \multicolumn{2}{|c|}{$\begin{array}{c}\text { Stedelifke } \\
\text { gemeenten } \\
(N=70)\end{array}$} \\
\hline & $\stackrel{r}{\text { totael }}$ & $\frac{r}{\text { partieel }}$ & $\begin{array}{c}r \\
\text { totaal }\end{array}$ & $\begin{array}{c}r \\
\text { partieel }\end{array}$ & $\begin{array}{c}r \\
\text { totaal }\end{array}$ & $\begin{array}{c}\Gamma \\
\text { partieel }\end{array}$ \\
\hline $\begin{array}{l}\text { Index economische } \\
\text { diversiteit }\end{array}$ & -.59 & -.52 & -.58 & -.58 & -.56 & -.50 \\
\hline $\begin{array}{l}\text { Eeroepsbevolking } \\
\text { met }>1.0 .\end{array}$ & -.42 & -.47 & .04 & -.16 & -.51 & -.43 \\
\hline $\begin{array}{l}\text { Index ij jfersprodu- } \\
\text { cerende instanties }\end{array}$ & -.42 & -.04 & -.00 & .18 & -.08 & .01 \\
\hline Aantal inwoners & -.33 &.$\quad .05$ & .01 & .00 & -.10 & -.01 \\
\hline Bevolkingsdichtheid & -.39 & -.17 & -.21 & -.10 & -.11 & .03 \\
\hline
\end{tabular}

Deze analyse-uitkomsten zijn in overeenstemming met de verwachtingen. De index economische diversiteit heeft ook na partialisering een duidelijk negatief effekt op de index normatieve integratie: voor de totale onderzoekspopulatie bedraagt de partiële correlatie -.52. In de categorieën plattelandsgemeenten en stedelijke gemeenten zijn de partiële correlaties van gelijke sterkte - respectievelijk -.58 en - .50. Het percentage beroepsbevalking met voortgezet onderwijs blijkt eveneens negatief samen te hangen met de index normatieve integratie. Deze samenhang is voor de totale onderzoekspopulatie en de categorie stedelijke gemeenten vrijwel even 
sterk (de partiële correlaties zijn respectievelijk -.47 en -.43); binnen de categorie plattelandsgemeenten is de correlatie aanzienlijk lager, doch wel negatief $(r=-.16)$. De onderzoeksresultaten bevestigen dus zowel hypothese 8 als hypothese 9: een grotere economische diversiteit alsook een hoger percentage beroepsbevolking met voortgezet onderwijs gaan gepaard met lagere scores op de index normatieve integratie.

Voor het totale aantal gemeenten en voor de beide urbanisatiegraadcategorieën werd de multiple correlatie van de index economische diversiteit en het percentage beroepsbevolking met $>1.0$. met de index normatieve integratie berekend. Daaruit kan worden gekonkludeerd, dat voor het tatale aantal gemeenten de index economische diversiteit en het percentage beroepsbevolking met meer dan alleen lager onderwijs tesamen ruim de helft (namelijk 54.3\%) van de variantie van de index normatieve integratie verklaren $(R=.74)$. Voor de plattelandsgemeenten $(R=.58)$ en voor de stedelijke gemeenten $(R=.67)$ zijn deze percentages verklaarde variantie lager, respectievelijk $34.1 \%$ en $45.3 \%$.

In het model werden geen uitspraken gedaan over de relatie van de ander onafhankelijke variabelen met de index normatieve integratie. Uit de, uiteraard, wel berekende correlaties blijkt, dat zich nauwelijks samenhangen van enig belang voordoen. Bij het totale aantal gemeenten vertoont, na partialisering van de correlaties, alleen de bevolkingsdichtheid een zwakke, negatieve samenhang met de index normatieve integratie $(r=$ -.17, tabel 12) -er is dus sprake van een lichte tendens tot lagere scores op de index normatieve integratie in geval van een grotere bevolkingsdichtheid.

Voor de overige variabelen zijn de partiële correlaties te laag om van enige betekenis te zijn. Als de variabelen bevolkingsdichtheid en aantal inwoners en de index cijfersproducerende instanties bij de berekening van de multiple correlatie worden betrokken bewerkstelligt dit dan ook de stijging van slechts $0.9 \%$ verklaarde variantie van de index normatieve integratie.

Binnen de categorie plattelandsgemeenten brengt de toevoeging van deze variabelen een stijging van $2.5 \%$ verklaarde variantie te weeg. Deze stijging is toe te schrijven aan de zwakke, positieve correlatie van de index normatieve integratie met: de index cijfersproducerende instanties ( $r=.18$ ). Zoals tabel 12 te zien geeft, correleert binnen de categorie 
stedelijke gemeenten geen van de drie variabelen met de index normatieve integratie -hun toevoeging tot de berekening van de multiple correlatie heeft dan ook geen enkel effekthet percentage verklaarde variantie blijft $45.3 \%$. 
9 TOETSING VAN HET MODEL II: DE RELATIES TUSSEN DE ONAFHANKELIJKE EN DE AFHANKELIJKE VARIABELEN

Dit hoofdstuk bevat de uitkomsten van de multiple regressieanalyse voor de hypothesen 10 tot en met 14 . Ook hier wordt volstaan met de korte weergave van de analyse-uitkomsten per hypothese, waarbij deze uitkomsten telkens in een afzonderlijke tabel zullen worden gepresenteerd. Ter wille van de overzichtelijkheid worden daaraan voorafgaand in een tweetal tabellen de nulde orde correlaties, de $\beta$ coëfficiënten en de multiple correlaties van de zes onafhankelijke variabelen met elk van de afhankelijke variabelen gezamenlijk weergegeven.

Tabel 13 a bevat de uitkomsten voor de afhankelijke variabelen vluchtgedrag, echtscheidingen en zelfmoord, Tabel 13b vermeldt de resultaten voor de afhankelijke variabelen agressief gedrag, vermogensmisdrijven en agressieve misdrijven, voor zowel de totale onderzoekspopulatie als de beide urbanisatiegraadcategorieën. Zoals aangekondigd zullen de konsekwenties van de toetsingsresultaten voor het conceptuele model worden besproken in hoofdstuk 10. 


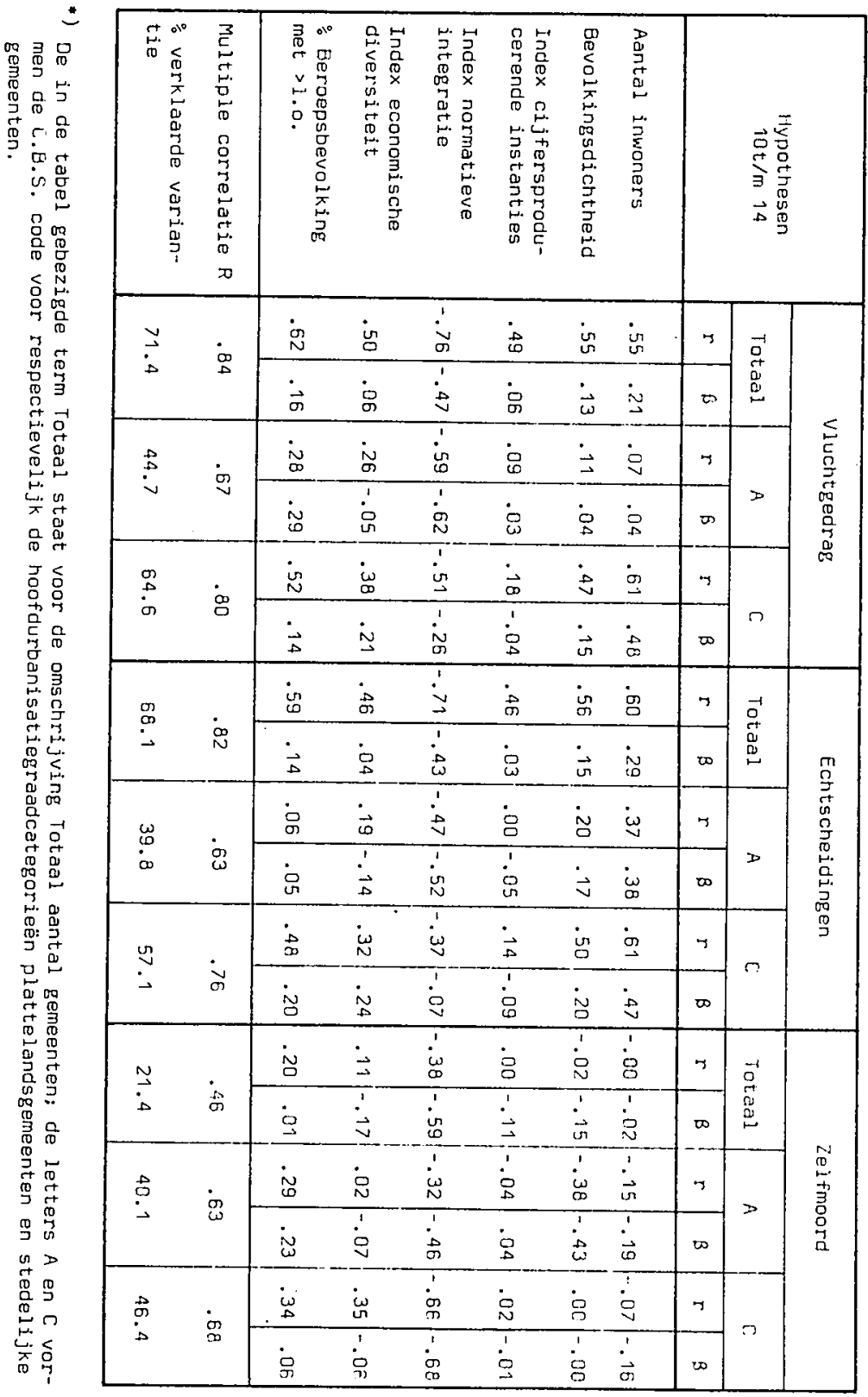

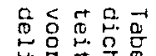

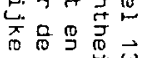

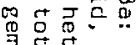

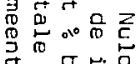

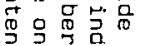

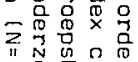

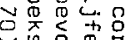

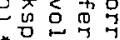

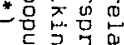

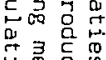

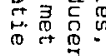

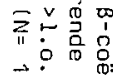
$\overrightarrow{0}$ 2 in

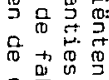

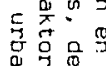

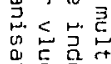

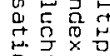

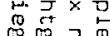
哭号 员苟寻

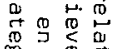

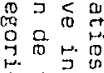

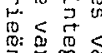

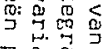
문 怘

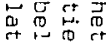
+ : ถิ

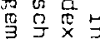

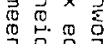

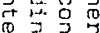
ป品

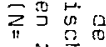

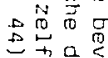

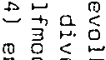
क 2 口 is 0.0 


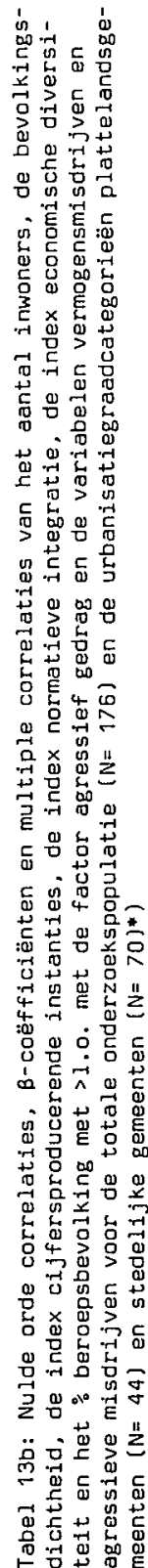

\begin{tabular}{|c|c|c|c|c|c|c|c|c|c|c|}
\hline \multirow{6}{*}{ 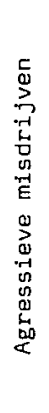 } & \multirow{2}{*}{ u } & $\infty$ & $\stackrel{\text { Niv }}{\text { N. }}$ & $\stackrel{0}{0}$ & $\stackrel{\check{N}}{\sim}$ & $\stackrel{m}{m}$ & 8 & $\because$ & \multirow{2}{*}{ 号 } & \multirow{2}{*}{$\bar{n}$} \\
\hline & & 4 & $\stackrel{N}{ֶ}$ & 웅 & $\stackrel{n}{\longleftarrow}$ & $\stackrel{9}{\mathrm{~m}}$ & $\stackrel{?}{\stackrel{?}{*}}$ & 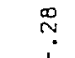 & & \\
\hline & \multirow{2}{*}{$\ll$} & $\infty$ & $\stackrel{m}{?}$ & ?? & 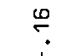 & $\stackrel{\widetilde{P}}{\dddot{N}}$ & $\stackrel{m}{5}$ & & \multirow{2}{*}{$\begin{array}{c}\infty \\
0 \\
0 .\end{array}$} & \multirow{2}{*}{$\stackrel{\circ}{a}$} \\
\hline & & $m$ & $\stackrel{?}{i}$ & ?ี. & $\stackrel{g}{9}$ & $\stackrel{M}{\circ}$. & $\stackrel{\infty}{\longleftarrow}$ & $\underset{\tilde{\sigma}}{\tilde{q}}$ & & \\
\hline & \multirow{2}{*}{$\begin{array}{l}0-1 \\
0 \\
0 \\
0 \\
0\end{array}$} & $\infty$ & & 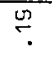 & $\stackrel{d}{\sim}$ & లి. & $\stackrel{2}{v}$ & & \multirow{2}{*}{ g. } & \multirow{2}{*}{$\dot{\stackrel{\sim}{N}}$} \\
\hline & & 4 & & ?ִ & $\stackrel{\leftrightarrow}{\circ}$ & $\stackrel{\stackrel{N}{\longrightarrow}}{.}$ & $\stackrel{8}{0}$ & $\stackrel{n}{?}$ & & \\
\hline \multirow{6}{*}{ 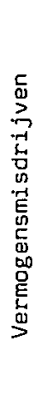 } & \multirow{2}{*}{0} & $\infty$ & פू & g. & $\stackrel{\infty}{\sim}$ & $\stackrel{N}{N}$ & $\stackrel{\infty}{0}$ & $\stackrel{0}{\circ}$ & \multirow{2}{*}{ 㐫. } & \multirow{2}{*}{$\dot{m}$} \\
\hline & & is & $\stackrel{\infty}{\square}$. & ๊ิ & $\stackrel{\infty}{m}$ & 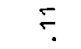 & 음 & 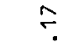 & & \\
\hline & \multirow{2}{*}{$\ll$} & $\infty$ & g. & $\stackrel{n}{q}$ & $\underset{N}{N}$ & ขै & $\stackrel{m}{m}$ & ఫே & \multirow{2}{*}{$\begin{array}{l}0 \\
0 . \\
0 .\end{array}$} & \multirow{2}{*}{$\begin{array}{l}N \\
\infty \\
\sigma \\
\sigma\end{array}$} \\
\hline & & m & 号. & ¿n. & $\stackrel{\infty}{m}$ & $\check{\circ}$ & ตे? & $\stackrel{m}{\leftarrow}$ & & \\
\hline & \multirow{2}{*}{$\begin{array}{l}\overrightarrow{0} \\
\mathbb{0} \\
+ \\
\stackrel{0}{\circ} \\
\end{array}$} & $\infty$ & m. & $\stackrel{\infty}{r}$ & $\hat{\Upsilon}$ & $\stackrel{?}{?}$ & 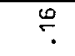 & $\stackrel{n}{\circ}$ & \multirow{2}{*}{$\ddot{~}$} & \multirow{2}{*}{$\stackrel{\sigma}{\dot{\sigma}}$} \\
\hline & & 5 & in & $\stackrel{g}{g}$ & $\hat{f}$ & $\stackrel{\text { N }}{\dddot{1}}$ & हे. & $\stackrel{N}{N}$ & & \\
\hline \multirow{6}{*}{ 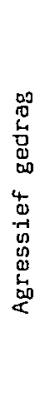 } & \multirow{2}{*}{ ט } & $\infty$ & $m$ & 임 & $\hat{N}$ & $\tilde{F}$ & $\stackrel{\circ}{\circ}$ & $\delta$ & \multirow{2}{*}{$\check{\varphi}$} & \multirow{2}{*}{$\stackrel{\circ}{m}$} \\
\hline & & 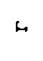 & $\bar{\sigma}$ & 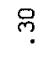 & m & $\bar{n}$ & $\stackrel{\sigma}{\stackrel{7}{~}}$ & ฮั. & & \\
\hline & \multirow{2}{*}{$\alpha$} & $\infty$ & g. & q & $\stackrel{\circ}{\circ}$ & $\stackrel{m}{\vartheta}$ & $\stackrel{M}{N}$ & $\stackrel{n}{N}$ & \multirow{2}{*}{ ఝ. } & \multirow{2}{*}{$\begin{array}{l}\tilde{\sim} \\
\stackrel{\sim}{\sigma}\end{array}$} \\
\hline & & L & 모 & q & $\stackrel{M}{\sim}$ & $\check{v}$ & $\stackrel{\infty}{\digamma}$ & $\bar{m}$ & & \\
\hline & \multirow{2}{*}{$\begin{array}{l}\vec{D} \\
\stackrel{0}{0} \\
\stackrel{0}{0}\end{array}$} & $\infty$ & $\stackrel{\infty}{\sim}$ & $\stackrel{?}{\leftarrow}$ & $\stackrel{g}{ָ}$ & m. & $\stackrel{\sigma}{r}$ & $\stackrel{n}{\square}$ & \multirow{2}{*}{$\stackrel{n}{n}$} & \multirow{2}{*}{ p. } \\
\hline & & $H$ & $\stackrel{\infty}{m}$ & m. & $\stackrel{m}{m}$ & $\stackrel{2}{0}$ & $\cong$ & . & & \\
\hline & 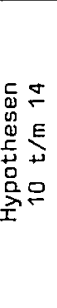 & & 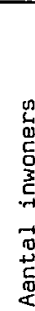 & 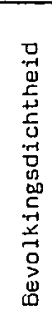 & 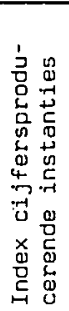 & 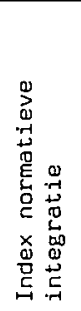 & 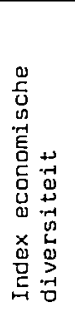 & 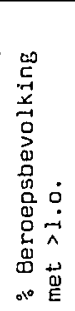 & \multicolumn{2}{|c|}{ 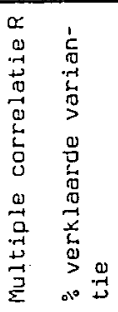 } \\
\hline
\end{tabular}

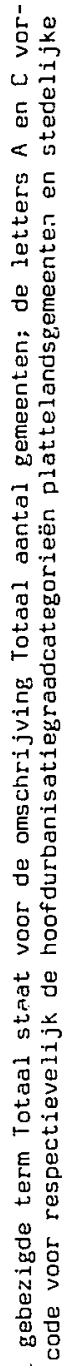

苛

웜

둥

๑) 离

? 


\subsection{Resultaten hypothese 10}

Wat betreft de effekten van het aanta: inwoners op de onderscheiden gedragsvariabelen gelcien de volgende verwachtingen: Hypothese 10: a. Het aantal inwoners heeft een positief effekt op de faktor vluchtgedrag en de variabelen echtscheidingen, zelfmoord en vermogensmisdrijuen en een negatief effekt of de variabele agressieve misdrijven. Het effekt op de faktor agressief gedrag is niet te voorspellen.

b. De effekten voor het aantal inwoners op de gedragsvariabelen zijn in geval van een relatief grote bevolkingsdichtheid -in casu de urbanisatiegraadcategorie stedelijke gemeentensterker dan bij een relatief geringe bevolkingsdichtheid -in casu de urbanisatiegraadcategorie plattelandsgemeenten.

De toetsingsresultaten voor deze hypothese, weergegeven in de tabellen 13a en 13b, worden samengevat in tabel 14.

Tabel 14: Viulde orce correlaties er, B-coëfficiënten van het aantel inwaliers met de gedragsvariabelen voor de totale onderzoekspopulatie (Totaal), de plattelandsgemeenten (A) en ä stedelijke gemeenten (C). (Overgenomen uit de tabellen $13 \mathrm{z}$ er. i3t)

\begin{tabular}{|c|c|c|c|c|c|c|c|c|c|c|c|c|}
\hline \multirow{3}{*}{ Populatie } & \multicolumn{12}{|c|}{ Gedragsvarieteler } \\
\hline & \multicolumn{2}{|c|}{$\begin{array}{l}\text { Vlucht- } \\
\text { gedrag }\end{array}$} & \multicolumn{2}{|c|}{$\begin{array}{c}\text { Echt- } \\
\text { scheidingen }\end{array}$} & \multicolumn{2}{|c|}{ Zelfmoord } & \multicolumn{2}{|c|}{$\begin{array}{l}\text { Agressief } \\
\text { gedrag }\end{array}$} & \multicolumn{2}{|c|}{$\begin{array}{l}\text { Vermogens- } \\
\text { misdrijuen }\end{array}$} & \multicolumn{2}{|c|}{$\begin{array}{l}\text { Agressieve } \\
\text { miscrijuen }\end{array}$} \\
\hline & $r$ & B & $r$ & B & $r$ & $\beta$ & $r$ & $\beta$ & $r$ & B & $r$ & B \\
\hline Totaal & .55 & .21 & .50 & .29 & -.00 & -.02 & .38 & $.2 \varepsilon$ & .54 & .35 & -.09 &.$-: 1$ \\
\hline A & .07 & .04 & .37 & .38 & -.15 & -.18 &.$- r s$ & -.03 & .04 & .04 & -.20 & -.13 \\
\hline C & .61 & .48 & .61 & .47 & -.07 & -.16 & .41 & .33 & .48 & .39 & -.22 & -.25 \\
\hline
\end{tabular}

In de totale onderzoekspopulatie correleert het aantal inwoners inderdaad positief met het vluchtgedrag $(r=.55)$, de echtscheidingen $(r=.60)$ en de vermogensmisdrijven $(r=.54)$. Deze samenhangen zijn slechts gedeeltelijk te herleiden tot de interrelaties met andere variabelen van het model. Ook nadat in de multiple regressie-analyse de invloed van deze in- 
terrelaties is uitgeschakeld blijft er sprake van een positief effekt van het inwonertal op het vluchtgedrag $(\beta=.21)$, de echtscheidingen $(\beta=.29$ ) en de vermogensmisdrijven ( $\beta=$ .35). De gemeentegrootte heeft geen effekt op het zelfmoordcijfer $(\beta=-.02)$.

Voor de agressieve misdrijven is het negatieve effekt van het aantal inwoners weliswaar gering, maar wel in de voorspelde richting $(\beta=-.11)$.

De faktor agressief gedrag tenslotte, blijkt door het aantal inwoners positief te worden beinvloed $(\beta=.28)$, wat gezien het feit dat niet alleen de variabele agressieve misdrijven, maar ook de variabele vermogensmisdrijven positief op deze faktor laadt, niet zo verwonderlijk is.

Hoewel de verschillen niet steeds even groot zijn, is het effekt van het aantal inwoners op de gedragsvariabelen in de categorie stedelijke gemeenten duidelijk sterker dan in de categorie plattelandsgemeenten - dit opnieuw met uitzondering van de variabele zelfmoord.

Bij de plattelandsgemeenten en stedelijke gemeenten zijn de $\beta$-coëfficiënten van het aantal inwoners met het vluchtgedrag respectievelijk .04 en .48, met de echtscheidingen .38 en .47 , de vermogensmisdrijven .04 en .39 en met de agressieve misdrijuen -.13 en -.25 . Voor de faktor agressief gedrag doet zich eenzelfde verschil voor -de $\beta$-coëfficiënten zijn respectievelijk -.03 en .33.

Wat betreft het zelfmoordcijfer geldt een zwakke tendens in tegengestelde richting -in de categorieën plattelandsgemeenten en stedelijke gemeenten zijn de $\beta$-coëfficiënten van het inwonertal achtereenvolgens -.19 en -.16.

Indien de afwijkende uitkomst voor het zelfmoordcijfer buiten beschouwing wordt gelaten, kan samenvattend worden gekonkludeerd dat hypothesen $10 \mathrm{a}$ en 10b door de analyseresultaten worden bevestigd.

De scores voor viuchtgedrag en de frekwenties van echtscheidingen en (opgeloste) vermogensmisdrijven zijn hoger naarmate het aantal inwoners groter is, terwijl er voor de agressieve misdrijven zowel in de plattelandsgemeenten als in de stedelijke gemeenten sprake is van een tendens tot lagere frekwenties in geval van een groter aantal inwoners. Zoals verwacht in hypothese $10 \mathrm{~b}$ worden deze effekten gekonditioneerd door de bevolkingsdichtheid: de invloed van het aantal inwoners op de frekwenties van de verschillende gedragswijzen is sterker in geval van een grotere bevolkingsdichtheid. 
9.2 Resultaten hypothese 11

Over de effekten van de bevolkingsdichtheid op de gedragsvariabelen werden de volgende veronderstellingen geformuleerd:

Hypothese 11: a. In geval van een relatief gering aantal inwoners -in casu de urbanisatiegraadcategorie plattelandsgemeenten- heeft de bevalkingsdichtheid een negatief effekt op de faktor vluchtgedrag en de variabelen echtscheidingen, zelfmoord en vermogensmisdrijven en een positief effekt op de variabele agressieve misdrijven. Het effekt op de faktor agressief gedrag is niet te voorspellen.

b. In geval van een relatief groot aantal inwoners - in casu de urbanisatiegraadcategorie stedelijke gemeenten- zijn de effekten van de bevolkingsdichtheid op de gedragsvariabelen van weinig betekenis meer dan wel tegengesteld van richting.

De analyseresultaten voor deze hypothese worden samengevat in tabel 15.

Tabel 15: Nulde orde correlaties en B-coëfficiënten van de bevolkingsdichtheid met de gedragsvariabelen voor de totale onderzoekspopulatie (Totaal), de plattelandsgemeenten (A) en de stedelijke gemeenten (C). (Overgenomen wit de tabellen $13 a$ en 13b)

\begin{tabular}{|c|c|c|c|c|c|c|c|c|c|c|c|c|}
\hline \multirow{3}{*}{ Populatie } & \multicolumn{12}{|c|}{ Gedragsvariabelen } \\
\hline & \multicolumn{2}{|c|}{$\begin{array}{l}\text { Vlucht- } \\
\text { gedrag }\end{array}$} & \multicolumn{2}{|c|}{$\begin{array}{c}\text { Echt- } \\
\text { scheidingen }\end{array}$} & \multicolumn{2}{|c|}{ Zelfmoord } & \multicolumn{2}{|c|}{$\begin{array}{l}\text { Agressief } \\
\text { gedrag }\end{array}$} & \multicolumn{2}{|c|}{$\begin{array}{l}\text { Vermogens- } \\
\text { misdrijuen }\end{array}$} & \multicolumn{2}{|c|}{$\begin{array}{l}\text { Agressieve } \\
\text { misdrijuen }\end{array}$} \\
\hline & $r$ & B & $r$ & B & $\mathrm{r}$ & $B$ & $r$ & B & $r$ & B & $\mathrm{r}$ & B \\
\hline Totaal & .55 & .13 & .56 & .15 & -.02 & -.15 & .34 & .19 & .49 & .18 & .03 & .19 \\
\hline A & .11 & .04 & .20 & .17 & -.38 & -.43 & .45 & .40 & .54 & .45 & .53 & .53 \\
\hline c & .47 & .15 & .50 & .20 & .00 & -.00 & .30 & .09 & .32 & .04 & -.07 & .07 \\
\hline
\end{tabular}

De uitkomsten van de analyse zijn tegenstrijdig. Binnen de categorie plattelandsgemeenten gaat inderdaad een sterkere concentratie van de bevolking gepaard met enerzijds lagere zelfmoordcijfers $(\beta=-.43)$ en anderzijds hogere frekwenties van agressieve misdrijven $(\beta=.53)$. Echter, in 
tegenstelling tot de verwachting, varieert in deze urbanisatiegraadcategorie het vluchtgedrag niet of nauwelijks met de bevalkingsdichtheid $(\beta=.04)$ en is er voor de echtscheidingen en de vermogensmisdrijven in geval van een grotere bevolkingsdichtheid sprake van een tendens tot hogere in plaats van lagere frekwenties (de $\beta$-coëfficiënten zijn respectievelijk.17 en .45).

Hypothese 11a wordt dus slechts gedeeltelijk bevestigd. Wat betreft hypothese 11b worden de verwachtingen voor de variabelen zelfmoord, vermogensmisdrijven en agressieve misdrijven door de analyseresultaten ondersteund: bij de stedelijke gemeenten heeft de bevolkingsdichtheid op deze gedragsvariabelen geen effekt van betekenis (de $\beta$-coëfficiënten zijn achtereenvolgens -.00, .04 en .07).

Aangezien bij de plattelandsgemeenten negatieve effekten werden verwacht zouden de bij de stedelijke gemeenten gevonden positieve effekten van de bevolkingsdichtheid op de variabelen vluchtgedrag $(\beta=.15)$ en echtscheidingen $(\beta=$ .20 ) dus als een bevestiging van hypothese 11b kunnen worden opgevat. Het feit echter dat anders dan verwacht bij de plattelandsgemeenten voor deze gedragsvariabelen van negatieve samenhangen met de bevolkingsdichtheid geen sprake bleek te zijn, doet twijfel rijzen aan de betekenis van deze uitkomsten. Deze twijfel geldt trouwens ook ten aanzien van de resultaten voor de vermogensmisdrijven.

Het is niet uitgesloten dat zowel in de plattelandsgemeenten als in de stedelijke gemeenten de gevonden effekten van de bevolkingsdichtheid op de gedragsvariabelen berusten op een ander mechanisme dan in het conceptuele model werd verondersteld.

In dit verband lijkt het raadzaam deze resultaten, ook in geval van een letterlijke overeenstemming met de hypothese 11a en 11b, met enige reserve te bezien.

\subsection{Resultaten hypothese 12}

De veronderstelling over het effekt van de index cijfersproducerende instanties luidt:

Hypothese 12: De index cijfersproducerende instanties heeft een positief effekt op elk van de onderscheiden gedragsvariabelen.

In tabel 16 worden de analyse-uitkomsten voor deze hypothese weergegeven. 
Tabel 16: Nulde orde correlaties en B-coëfficiënten van de index cijfersproducerende instanties met de gedragsvariabelen voor de totale onderzoekspopulatie (Totaal), de plattelandsgemeenten (A) en de stedelijke gemeenten (C). (Overgenomen uit de tabellen 13a en 13b)

\begin{tabular}{|c|c|c|c|c|c|c|c|c|c|c|c|c|}
\hline \multirow{3}{*}{ Populatie } & \multicolumn{12}{|c|}{ Gedragsvariacilen } \\
\hline & \multicolumn{2}{|c|}{$\begin{array}{l}\text { Vlucht- } \\
\text { gedrag }\end{array}$} & \multicolumn{2}{|c|}{$\begin{array}{c}\text { Echt- } \\
\text { scheidingen }\end{array}$} & \multicolumn{2}{|c|}{ Zelfmoord } & \multicolumn{2}{|c|}{$\begin{array}{l}\text { Agressief } \\
\text { gedrag }\end{array}$} & \multicolumn{2}{|c|}{$\begin{array}{l}\text { Vermogens- } \\
\text { misdrijven }\end{array}$} & \multicolumn{2}{|c|}{$\begin{array}{l}\text { Agressieve } \\
\text { misorijuen }\end{array}$} \\
\hline & r & B & $r$ & B & $r$ & $B$ & $\Gamma$ & B & $r$ & B & $r$ & $B$ \\
\hline Totaal & .49 & .06 & .46 & .03 & .00 & -.11 & .33 & .29 & .47 & .27 & .06 & .24 \\
\hline A & .09 & .03 & .00 & -.05 & -.04 & .04 & .23 & .16 & .38 & .22 & -.09 & -.16 \\
\hline c & .18 & -.04 & .14 & -.09 & .02 & -.01 & .35 & .27 & .38 & .26 & .15 & .26 \\
\hline
\end{tabular}

Zoals de tabel laat zien stemmen de toetsingsresultaten voor de variabelen vluchtgedrag, echtscheidingen en zelfmoord niet overeen met de verwachtingen.

De in de totale onderzoekspopulatie tamelijk hoge positieve correlaties van de index cijfersproducerende instanties met het vluchtgedrag $(r=.49)$ en de echtscheidingen $(r=.46)$ blijken te moeten worden toegeschreven aan interrelaties met andere onafhankelijke variabelen uit het model. Blijkens de resultaten van de multiple regressieanalyse is het effekt van de index cijfersproducerende instanties op deze gedragsvariabelen na uitschakeling van de invloed van de overige onafhankelijke variabelen van geen betekenis meer, de $\beta$-coëfficiënten zijn respectievelijk .06 en .03. Wat betreft de zelfmoord hebben noch de nulde orde correlatie noch de regressiecoëfficiënt veel te betekenen: $r=.00, \beta=-.11$. De hier besproken correlaties zijn in de beide urbanisatiegraadcategorieën niet veel hoger.

De index cijfersproducerende instanties blijkt inderdaad wel een positief effekt te hebben op de faktor agressief gedrag en de variabelen vermogensmisdrijven en agressieve misdrijven. Hoewel niet bijzonder hoog geven de $\beta$-coëfficiënten in de totale onderzoekspopulatie, respectievelijk $.29, .27$ en .24 , een tendens te zien tot hogere frekwenties van agressief gedrag, vermogensmisdrijven en agressieve misdrijven in geval 
van een grotere concentratie van cijfersproducerende instanties in de gemeente. Met uitzondering van de, overigens zwakke, negatieve samenhang met de agressieve misdrijven in de categorie plattelandsgemeenten $(\beta=-.16)$ geldt deze tendens ook binnen de beide urbanisatiegraadcategorieën. Samenvattend kan dus worden gekonkludeerd dat de toetsingsresultaten hypothese 12 noch volledig ontkennen noch volledig bevestigen.

De hypothese wordt ontkend voor zover het de variabelen vluchtgedrag, echtscheidingen en zelfmoord betreft; aangaande de variabelen agressief gedrag, vermogensmisdrijven en agressieve misdrijven wordt de hypothese evenwel bevestigd.

\subsection{Resultaten hypothesen 13 en 14}

Tenslotte werden over de effekten van de index normatieve integratie op de gedragsvariabelen de volgende hypothesen opgesteld:

Hypothese 13: De index normatieve integratie heeft een negatief effekt op de faktor vluchtgedrag en de variabelen echtscheidingen en zelfmoord en een positief effekt op de faktor agressief gedrag en de variabelen vermogensmisdrijven en agressieve misdrijven.

Hypothese 14: Het negatieve effekt van de index normatieve integratie op de faktor vluchtgedrag en de variabelen echtscheidingen en zelfmoord is sterker dan het positieve effekt op de faktor agressief gedrag en de variabelen vermogensmisdrijven en agressieve misdrijven.

In tabel 17 worden de toetsingsresultaten voor deze hypothesen weergegeven.

Uit deze tabel valt af te lezen, dat in de totale onderzoekspopulatie de index normatieve integratie een duidelijk, van de overige variabelen onafhankelijk, negatief effekt heeft op het vluchtgedrag, de echtscheidingen en de zelfmoord, de $\beta$ coëfficiënten zijn achtereenvolgens -.47, -.43 en -.59. Overeenkomstig de verwachtingen zijn dus de scores op de faktor vluchtgedrag en de geregistreerde frekwenties van de echtscheidingen en de zelfmoord hoger naarmate de gemeenten lager scoren op de index normatieve integratie. Deze konstatering geldt ook voor de beide urbanisatiegraadcategorieën afzonderlijk, zij het dan dat in de categorie stede- 
lijke gemeenten het effekt van de index normatieve integratie op de echtscheidingen zeer zwak is $(\beta=-.07)$.

Tabel 17: Nulde orde correlaties en B-coëfficiënten van de index normatieve integratie met de geciragsvariabelen voor de totale onderzoekspopulatie (Totaal), de plattelandsgemeenten (A) en de stedelijke gemeenten (C). (Uvergenomen vit de tabellen 13a en 13b)

\begin{tabular}{|c|c|c|c|c|c|c|c|c|c|c|c|c|}
\hline \multirow{3}{*}{ Populatie } & \multicolumn{12}{|c|}{ Gedragsvariates: en } \\
\hline & \multicolumn{2}{|c|}{$\begin{array}{l}\text { Vlucht- } \\
\text { gedrag }\end{array}$} & \multicolumn{2}{|c|}{$\begin{array}{c}\text { Echt- } \\
\text { scheidinger }\end{array}$} & \multicolumn{2}{|c|}{ Zelfmoord } & \multicolumn{2}{|c|}{$\begin{array}{l}\text { Agressief } \\
\text { Eeorag }\end{array}$} & \multicolumn{2}{|c|}{$\begin{array}{l}\text { Vermogens - } \\
\text { misdrijuen }\end{array}$} & \multicolumn{2}{|c|}{$\begin{array}{l}\text { Agressieve } \\
\text { misdrijuen }\end{array}$} \\
\hline & $r$ & $\beta$ & $r$ & $B$ & $r$ & B & $r$ & $B$ & $r$ & e & $r$ & B \\
\hline Totaal & -.76 & -.47 & -.71 & -.43 & -.38 & -.59 & .05 & .33 & -.25 & .10 & .25 & .30 \\
\hline$A$ & -.59 & -.62 & -.47 & -.52 & -.32 & -.46 & .21 & .43 & .01 & .32 & .03 & .23 \\
\hline $\mathrm{C}$ & -.51 & -.26 & -.37 & -.07 & -.65 & -.68 & .31 & .42 & .11 & .25 & .39 & .32 \\
\hline
\end{tabular}

Wat betreft het agressief gedrag en de agressieve misdrijven is er in de totale onderzoekspopulatie, eveneens volgens de verwachtingen, sprake van een tendens tot hogere frekwenties naarmate de gemeentelijke score op de index normatieve integratie hoger is (de $\beta$-coëfficiënten zijn respectievelijk .33 en .30).

Ofschoon evenzeer positief is het effekt op de vermogensmisdrijven van weinig betekenis $(\beta=.10)$.

In de beide urbanisatiegraadcategorieën afzonderlijk geldt het positieve effekt van de index normatieve integratie voor elk van de drie gedragsvariabelen -sommige $\beta$-coëfficiënten zijn zelfs wat hoger dan in de totale onderzoekspopulatie. Ondanks het verschil in gemiddelde score op de index normatieve integratie -relatief hoog voor de plattelandsgemeenten en relatief laag voor de stedelijke gemeenten (tabel 8)-geven de voor de beide urbanisatiegraadcategorieën afzonderlijk berekende samenhangen van deze index met de gedragsvariabelen geen systematisch verschil in sterkte te zien. De door Webb veronderstelde konditionering van de relaties door een beperkte spreidingsbreedte van de variabelen blijkt zich hier dus niet voor te doen.

Op grond van deze toetsingsresultaten kan tot de bevestiging van hypothese 13 worden gekonkludeerd: hoewel in twee gevallen de correlaties van weinig betekenis zijn, geeft de index 
normatieve integratie (in het totaal 18 correlaties) steeds een effekt in de verwachte richting te zien. Ter toetsing van hypothese 14 is, per onderzoekspopulatie (totaal aantal gemeenten, plattelandsgemeenten, stedelijke gemeenten), elk van de $\beta$-coëfficiënten voor de variabelen $v$ luchtgedrag, echtscheidingen en zelfmoord vergeleken met elk van de $\beta$-coëfficiënten voor de variabelen agressief gedrag, vermogensmisdrijven en agressieve misdrijven. Dit levert in totaal 27 vergelijkingsmogelijkheden op. In de totale onderzoekspopulatie geven de 9 vergelijkingen allen een verschil in de verwachte richting te zien: de negatieve $\beta$-coëfficiënten van de index normatieve integratie met de faktor vluchtgedrag, de echtscheidingen en de zeifmoord (respectievelijk -.47, -.43 en -.59) zijn elk hoger dan de positieve $\beta$-coëfficiënten met de faktor agressief gedrag, de vermogensmisdrijven en de agressieve misdrijven (achtereenvolgens. 33 , . 10 en .30).

In de beide urbanisatiegraadcategorieën blijkt voor 6 van de 18 vergelijkingen het verschil in sterkte zich niet voor te doen dan wel tegengesteld aan de verwachtingen te zijn. In totaal stemmen dus voor 21 van de 27 vergelijkingen de resultaten met de verwachtingen overeen.

Daarnaast kan nog worden opgemerkt dat 6 van de 9 negatieve $\beta$-coëfficiënten van de index normatieve integratie met het vluchtgedrag, de echtscheidingen en de zelfmoord hoger zijn dan .45 (gemiddelde $\beta=-.41$ ), tegen geen van de 9 positieve $\beta$-coëfficiënten met het agressief gedrag, de vermogensmisdrijven en de agressieve misdrijven (gemiddelde $\beta=.27$ ).

Gezien deze uitkomsten kan hypothese 14 als bevestigd worden beschouwd.

Ter afsluiting van deze paragraaf worden in tabel 18 de samenhangen van respectievelijk de index economische diversiteit en het percentage beroepsbevolking met elk van de gedragsvariabelen weergegeven. Daarbij worden opnieuw de analyseresultaten voor de index normatieve integratie vermeld -dit om de vergelijking van de uitkomsten te vergemakkelijken.

Zoals gesteld in $\$ 6.1$ wordt in het conceptuele model voor de arbeidsverdeling een indirekt, via de normatieve integratie en de professionele kontrole instanties verlopend, effekt op het afwijkend gedrag verondersteld, terwijl voor het opleidingsniveau een direkte relatie niet bij voorbat uitgesloten wordt geacht.

De resultaten voor de desbetreffende variabelen zijn niet geheel eensluidend. 
Tabel 18: B-coëfficiënten van de index normatieve integratie, de index economische diversiteit en het \% beroepsbevolking met $>1.0$. met de gedragsvariabelen vaor de totale onderzoekspopulatie (Totaal), de plattelandsgemeenten $(A)$ en de stedelijke gemeenten (C). (Overgenamen uit de tabellen $13 a$ en 13b)

\begin{tabular}{|c|c|c|c|c|c|c|c|}
\hline \multirow[b]{2}{*}{$\begin{array}{l}\text { Popu- } \\
\text { latie }\end{array}$} & \multirow[b]{2}{*}{ Indices } & \multicolumn{6}{|c|}{ Gedragsvariabelen } \\
\hline & & $\begin{array}{l}\text { Vlucht- } \\
\text { gedrag }\end{array}$ & $\begin{array}{l}\text { Echt- } \\
\text { schei- } \\
\text { dingen }\end{array}$ & $\begin{array}{l}\text { Zelf- } \\
\text { moord }\end{array}$ & $\begin{array}{l}\text { Agres- } \\
\text { sief } \\
\text { gedrag }\end{array}$ & $\begin{array}{l}\text { Vermo- } \\
\text { gensmis- } \\
\text { drijuen }\end{array}$ & $\begin{array}{l}\text { Agressie- } \\
\text { ve mis- } \\
\text { drijuen }\end{array}$ \\
\hline $\begin{array}{c}\text { Totaal } \\
\text {. }\end{array}$ & $\begin{array}{l}\text { Index normatie- } \\
\text { ve integratie } \\
\text { Index econo- } \\
\text { mische diver- } \\
\text { siteit } \\
\text { \% Beroepsue- } \\
\text { volking met } \\
>1.0 .\end{array}$ & $\begin{array}{r}-.47 \\
.06 \\
.16\end{array}$ & $\begin{array}{r}-.43 \\
.04\end{array}$ & $\begin{array}{l}-.59 \\
-.17 \\
.01\end{array}$ & .14 & $\begin{array}{r}.16 \\
-.05\end{array}$ & $\begin{array}{r}.30 \\
.23 \\
-.36\end{array}$ \\
\hline A & $\begin{array}{l}\text { Index normatie- } \\
\text { ve integratie } \\
\text { Index econo- } \\
\text { mische diver- } \\
\text { siteit } \\
\% \text { Beroepsbe- } \\
\text { volking met } \\
>1.0 .\end{array}$ & $\begin{array}{l}-.62 \\
-.05 \\
.29\end{array}$ & $\begin{array}{r}-.52 \\
-.14 \\
.05\end{array}$ & $\begin{array}{r}-.07 \\
.23\end{array}$ & $\begin{array}{r}.23 \\
-.25\end{array}$ & $\begin{array}{r}.32 \\
.38 \\
-.04\end{array}$ & $\begin{array}{r}.13 \\
-.27\end{array}$ \\
\hline C & $\begin{array}{l}\text { Index normatie- } \\
\text { ve integratie } \\
\text { Index econo- } \\
\text { mische diver- } \\
\text { siteit } \\
\% \text { Beroepsbe- } \\
\text { volking met } \\
>1.0 \text {. }\end{array}$ & $\begin{array}{r}-.26 \\
. \\
.21 \\
.14\end{array}$ & $\begin{array}{l}.24 \\
.20\end{array}$ & -.06 & .01 & .08 & $\begin{array}{l}-.02 \\
-.12\end{array}$ \\
\hline
\end{tabular}

Voor het totale aantal gemeenten kan wat de index economische diversiteit betreft worden gekonkludeerd dat alleen ten aanzien van de agressieve misdrijven sprake is van een onafhankelijk en direkt effekt. Dit (positieve) effekt is echter niet bijzonder sterk $(\beta=.23)$ en zelfs nog iets zwakker dan het effekt van de normatieve integratie op de agressieve misdrijven $(\beta=.30)$. Weliswaar is van de vermogensmisdrijven de $\beta$-coëfficiënt met de index economische diversiteit iets hoger dan 
die met de index normatieve integratie (respectievelijk . 16 en .10), maar op zich is deze coëfficiënt evenals de overigen met achtereenvolgens het vluchtgedrag, de echtscheidingen, de zelfmoord en het agressief gedrag te laag om varı enige betekenis te kunnen worden geacht ( $\beta$ is respectievelijk.06, $.04,-.17$ en .14).

Binnen de categorie plattelandsgemeenten blijkt de index economische diversiteit toch een direkte relatie te hebben met zowel het agressief gedrag $(\beta=.23)$ als de vermogensmisdrijuen ( $\beta=.38$ ). Het effekt op de vermogensmisdrijven is duidelijk van betekenis en bovendien nog iets sterker dan dat van de index normatieve integratie $(\beta=.32)$. Deze uitkomst is dus strijdig met de verwachtingen.

Bij de stedelijke gemeenten is in twee gevallen sprake van een onafhankelijk, zij het nogal zwak effekt van de index economische diversiteit, namelijk op het vluchtgedrag $(\beta=.21)$ en op de echtscheidingen ( $\beta=.24)$, waarbij het laatstgenoemde effekt duidelijk sterker is dan dat van de index normatieve integratie $(\beta=-.07)$.

Alles bijeengenomen kan worden vastgesteld dat van de in totaal 18 mogelijkheden (3 onderzoekpopulaties en 6 gedragsvariabelen) er 12 zijn, warin overeenkomstig de verwachtingen de index normatieve integratie wel en de index economische diversiteit geen direkt effekt van betekenis heeft op de betreffende gedragsvariabelen; in slechts 1 geval is het effekt van de index economische diversiteit èn relatief sterk èn sterker dan het effekt van de index normatieve integratie. Samenvattend kan worden gekonkludeerd dat, de veronderstelling over de indirekte relatie van de index economische diversiteit met het afwijkend gedrag duidelijk steun vindt in de toetsingsresultaten, maar daardoor niet volledig wordt bevestigd.

Het \% beroepsbevolking met meer dan lager onderwijs blijkt in slechts 6 van de 18 gevallen een min of meer duidelijk direkt en van de overige variabelen onafhankelijk effekt op de gedragsvariabelen te hebben. In 3 van deze 6 correlaties is dit effekt iets sterker dan dat van de index normatieve integratie. Bij het totale aantal gemeenten en bij de plattelandsgemeenten geldt dit de agressieve misdrijven: de $\beta$ coëfficiënten voor het \% beroepsbevolking met > lager onderwijs bedragen respectievelijk -.36 en -.27 en voor de index normatieve integratie .30 en . 23. Bij de stedelijke gemeenten is het effekt van het \% beroeps- 
bevolking met meer dan lager onderwijs op de variabele echtscheidingen ( $\beta=.20$ ) hoewel op zich niet bijzonder sterk, toch sterker dan dat van de index normatieve integratie $(\beta=-.07)$.

Binnen de categorie plattelandsgemeenten tenslotte is driemaal sprake van een direkt effekt van het \% beroepsbevolking met meer dan lager onderwijs, dat, hoewel lager dan dat van de index normatieve integratie toch van enige betekenis kan worden geacht. Dit betreft de effekten op het vluchtgedrag $(\beta=.29)$, de zelfmoord $(\beta=.23)$ en het agressief gedrag $(\beta=-.25)$.

Voor elk van deze 6 gevallen van een direkt, onafhankelijk effekt van het \% beroepsbevolking met meer dan lager onderwijs op de desbetreffende gedragsvariabelen geidt, dat de richting van de relaties in overeenstemming is met de verwachtingen die in het model ten aanzien van de effekten van het opleidingsniveau werden ontwikkeld: positief voor het viuchtgedrag, de echtscheidingen en de zelfmoord en negatief voor het agressief gedrag en de agressieve misdrijven. 
10. SAMENVATTING EN KONKLUSIES: ARBEIDSVERDELING, NORMATIEVE INTEGRATIE EN TYPEN VAN AFWIJKEND GEDRAG

\subsection{Samenvatting van de onderzoeksuitkomsten}

In het voorafgaande werden aangaande de overeenstemming van de hypothesen met de onderzoeksuitkomsten verschillende resultaten vastgesteld:

- volledige overeenstemming, de hypothese wordt door de uitkomsten bevestigd. Hiervan is sprake in geval hetzij geen correlatie indien de afwezigheid van een samenhang werd voorspeld, hetzij een matige tot hoge correlatie in de voorspelde richting.

- volledige tegenspraak, de hypothese wordt door de uitkomsten weersproken. Hiervan is sprake in geval hetzij geen correlatie indien wel een samenhang werd voorspeld, hetzij een al dan niet hoge correlatie in een richting tegengesteld aan de voorspelling.

- gedeeltelijke overeenstemming, de hypothese wordt door de uitkomsten deels bevestigd, deels verworpen. Hiervan is sprake in geval van hetzij een lage correlatie in de voorspelde richting, hetzij matige tot hoge correlaties in de voorspelde richting maar niet voor alle gevallen waarvoor de voorspelling werd gedaan.

De tabellen 19a en 19b bevatten een overzicht van de resultaten voor achtereenvolgens de hypothesen 1 tot en met 9 betreffende de onderlinge relaties van de onafhankelijke variabelen en de hypothesen 10 tot en met 14 over de samenhangen tussen de onafhankelijke en afhankelijke variabelen. In deze overzichten wordt de mate van overeenstemming tussen de hypothesen en de onderzoeksuitkomsten aangegeven met: ja = volledige overeenstemming, neen = volledige tegenspraak en wel/niet = gedeeltelijke overeenstemming.

Hoewel de meeste hypothesen gelden voor de totale onderzoekspopulatie, worden in deze tabellen volledigheidshalve ook de resultaten voor de plattelandsgemeenten en de stedelijke gemeenten samengevat.

Blijkens dit overzicht is het operationele model voor zover het de onderlinge relaties van de onafhankelijke variabelen betreft suksesvol. Gelet op de uitkomsten voor het totale aantal gemeenten worden vier van de negen hypothesen bevestigd (hypothesen 1, 5, 8 en 9 ). Voor twee hypothesen (4 en 5) geldt echter dat de correlatie, hoewel in de voorspelde richting erg zwak is, terwijl drie 
hypothesen (2, 3 en 7) door de resultaten worden weersproken.

Tabel 19d: Overzicht van de toetsingsresultaten voor de hypothesen $1 \mathrm{t} / \mathrm{m} 9$ van het operationele model, weergegeven voor het totale aantal gemeenten (Totaal), de plattelandsyeneenten $(A)$ en de stedelijke gemeenten (C).

\begin{tabular}{|c|c|c|c|}
\hline \multirow{2}{*}{ Hypothesen } & \multicolumn{3}{|c|}{$\begin{array}{l}\text { Overeenstemming met } \\
\text { onderzoeksresultaten }\end{array}$} \\
\hline & Totael & $A$ & $c$ \\
\hline 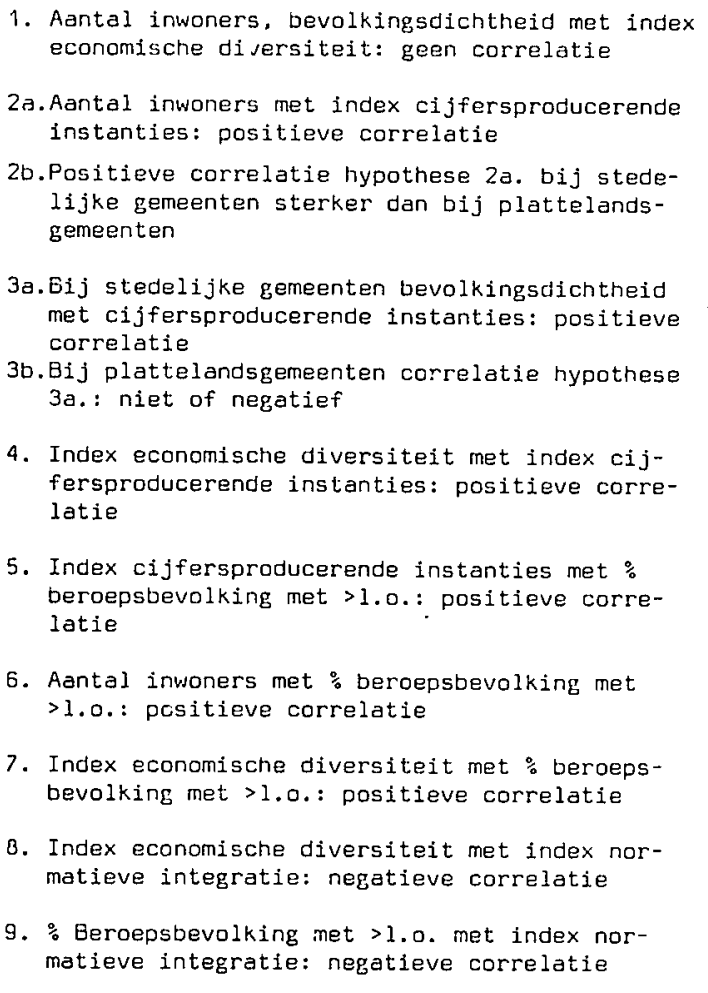 & $\begin{array}{l}\text { wel/ } \\
\text { niet } \\
\text { ja } \\
\text { wel/ } \\
\text { niet } \\
\text { neen }\end{array}$ & $\begin{array}{c}\text { neen } \\
\text { neen } \\
\text { ja } \\
\text { wel/ } \\
\text { niet }\end{array}$ & $\begin{array}{l}\text { wel/ } \\
\text { niet } \\
\text { wel/ } \\
\text { niet } \\
\text { neen }\end{array}$ \\
\hline
\end{tabular}

Wat betreft de variabelen kan de index normatieve integratie als de suksesrijkste worden aangewezen. Deze variabele figureert in twee hypothesen, die beiden door de vitkomsten van 
het onderzoek worden bevestigd. De index economische diversiteit en het \% beroepsbevolking met > lager onderwijs nemen in dit opzicht de tweede plaats in. Deze variabelen zijn betrokken bij in het totaal vier hypothesen, waarvan er twee volledig en één gedeeltelijk worden bevestigd.

De minst suksesrijke variabele is de index cijfersproducerende instanties: van de zes hypothesen waarbij deze variabele is betrokken warden er twee slechts gedeeltelijk bevestigd en drie volledig verworpen.

Tabel 19b: Overzicht van de toetsingsresultaten voor de hypothesen $10 \mathrm{t} / \mathrm{m} 14$ van het operationele model, weergegeven voor het totale aantal gemeenten (Totaal), de plattelandsgemeenten (A) en de stedelijke gemeenten ( $C$ ).

\begin{tabular}{|c|c|c|c|}
\hline \multirow{2}{*}{ Hypothesen } & \multicolumn{3}{|c|}{$\begin{array}{l}\text { Overeenstemming met } \\
\text { onderzoeksresultaten }\end{array}$} \\
\hline & Totaal & A & C \\
\hline $\begin{array}{l}\text { 10a. Aantal inwoners met vluchtgedrag, echtschei- } \\
\text { dingen, zelfmoord, vermogensmisdrijven: po- } \\
\text { sitieve correlatie } \\
\text { met agressieve misdrijven: negatieve corre- } \\
\text { latie } \\
\text { 10b. Bij stedelijke gemeenten correlatie hypothese } \\
\text { 10a. sterker dan bij plattelandsgemeenten } \\
\text { 11a. Eij plattelandsgemeenten bevolkingsdichtheid } \\
\text { met vluchtgedrag, echtscheidingen, zelfmoord, } \\
\text { vermogensmisdrijven: negatieve correlatie } \\
\text { met agressieve misdrijven: positieve correla- } \\
\text { tie } \\
\text { 110. Bij stedelijke gemeenten correlatie hypothese } \\
\text { 11a: niet of tegengesteld } \\
\text { 12. Index cijfersproducerende instanties met ge- } \\
\text { dragsvariabelen: positieve correlatie } \\
\text { 13. Index normatieve integratie met vluchtgedrag. } \\
\text { echtscheidingen, zelfmoord: negatieve corre- } \\
\text { latie } \\
\text { met agressieve misdrijven, vermogensmisdrij- } \\
\text { ven, agressief gedrag: positieve correlatie } \\
\text { 14. Negatieve correlatie gedragsvariabelen met } \\
\text { normatieve integratze sterker dan positieve } \\
\text { correlatie }\end{array}$ & $\begin{array}{l}\text { wel/ } \\
\text { niet } \\
\text { ja } \\
\text { ja***) }\end{array}$ & $\begin{array}{c}\text { neen *) } \\
j a\end{array}$ & $\begin{array}{l}\text { wel/ } \\
\text { niet } \\
\text { wel/ } \\
\text { niet }\end{array}$ \\
\hline
\end{tabular}

*) Met uitzondering van de zelfmoord - B is negatief.

*) Uitgezonderd de echtscheidingen - $B$ : s negatief, maar zeer laag.

***) Behalve de vermogensmisdrijuen - $B$ wel positief, maer laag 
Ook wat de voorspelling van de effekten van de onafhankelijke variabelen op de kriteriumvariabelen betreft kan het operationele model, gezien de uitkomsten voor het totale aantal gemeenten, suksesvol worden genoemd.

Drie van de vijf hypothesen worden grotendeels of volledig bevestigd (hypothesen 10,13 en 14), één hypothese (12) wordt gedeeltelijk bevestigd en slechts één hypothese (11) wordt door de onderzoeksresultaten vrijwel volledig verworpen. Van de onafhankelijke variabele is opnieuw de index normatieve integratie de suksesrijkste: in acht van de negen gevallen heeft deze index een duidelijk effekt in overeenstemming met de verwachting, in het negende geval is het effekt wel in de voorspelde richting, maar te laag. Met zes van de tien uitkomsten in strijd met de voorspellingen is de bevolkingsdichtheid de minst suksesvalle variabele. De index cijfersproducerende instanties tenslotte was eveneens minder suksesvol -voor deze index kon in slechts de helft van het aantal gevallen het verwachte effekt worden vastgesteld. De onderzoeksresultaten voor het totale aantal gemeenten kunnen tenslotte als volgt schematisch worden weergegeven:

Schema 3

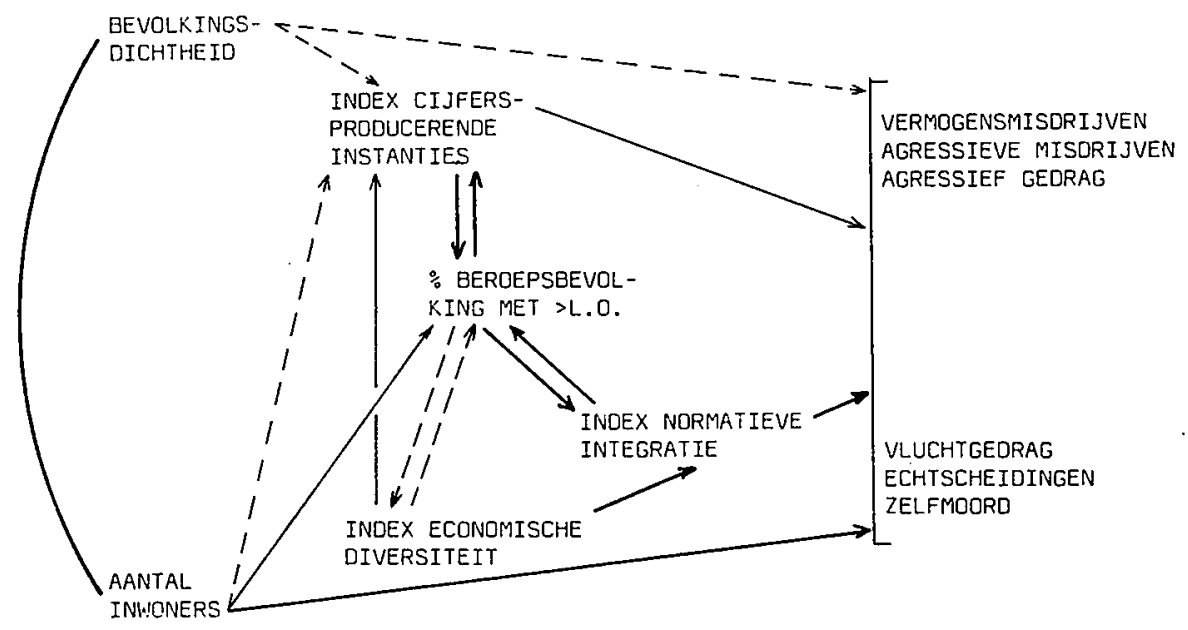

$\longrightarrow$ voorspelde en empirisch volledig bevestigde relaties.

$\longrightarrow$ Voorspelde en empirisch niet volledig bevestigde relaties.

$-\rightarrow \rightarrow$ loorspelde en empirisch niet bevestigde relaties. 
Het schema maakt zichtbaar, dat het operationele model niet volledig bruikbaar is gebleken. Desondanks kan toch van een tamelijk bevredigend resultaat worden gesproken. De beide kernhypothesen ( 8 en 13) van het model werden bevestigd voor zowel het totale aantal gemeenten als de plattelandsgemeenten en de stedelijke gemeenten. De index normatieve integratie correleert niet alleen in alle gevallen volgens de verwachting negatief met de index economische diversiteit, maar bovendien is deze correlatie ook steeds hoger dan die met de andere onafhankelijke variabelen. Wat betreft hypothese 13 geldt dat de richting van het effekt van de index normatieve integratie op de gedragsvariabelen steeds overeenstemt met de verwachting, terwijl bovendien in 12 van de 18 gevallen dit effekt sterker is dan dat van de overige variabelen. Gezamenlijk verklaren de onafhankelijke variabelen hoge tot zeer hoge percentages variantie van de onderscheiden kriteriumvariabelen -berekend voor het totale aantal gemeenten zijn dat voor de faktor vluchtgedrag en de variabelen echtscheidingen en zelfmoord respectievelijk 71.4\%, 68.1\% en $21.4 \%$ (tabel 13a) en voor de faktor agressief gedrag en de variabelen vermogensmisdrijven en agressieve misdrijven achtereenvolgens $30.0 \%, 41.4 \%$ en $24.1 \%$ (tabel 13b).

\subsection{Bespreking van de onderzoeksuitkomsten}

In deze paragraaf gat het om de betekenis van de uitkomsten van het onderzoek voor de hypothesen van het model. Bij de interpretatie van de resultaten zijn ook de al dan niet impliciete veronderstellingen betrokken warop de hypothesen en hun toetsing zijn gebaseerd. Deze veronderstellingen betreffen zowel de variabelen als de hypothesen zelf.

De veronderstellingen over de variabelen gelden enerzijds de mate van betrouwbaarheid, volledigheid en geldigheid van de gegevens waarmee de variabelen zijn gemeten en anderzijds de geldigheid van de variabelen als indikatoren voor de concepten van het model.

De veronderstellingen aangaande de hypothesen hebben betrekking op de redeneringen warop de verwachtingen over de relaties tussen de variabelen berusten, de werking van de verschijnselen op elkaar, de mechanismen van hun onderlinge samenhangen.

Deze veronderstellingen zijn van belang bij de beslissing over de betekenis van de overeenstemming en de niet-overeenstemming tussen onderzoeksuitkomsten en hypothesen. 
In het geval onderzoeksresultaten en hypothesen niet overeenstemmen moet worden beslist of daaruit inderdaad mag worden afgeleid, dat de hypothesen door deze uitslag zijn gefalsificeerd en dat daarmee de proposities van het theoretisch model als verworpen moeten worden beschouwd. Om tot deze beslissing te komen moet worden nagegaan of deze uitslag wellicht is toe te schrijven aan onbetrouwbare metingen, aan ongeldige indiceringen of aan de werking van andere, eveneens met het theoretische model verenigbare mechanismen. Er moet dus aandacht worden besteed aan de houdbaarheid van de bijkomende veronderstellingen. Evenzo moet worden tueslist of in geval van overeenstemming tussen onderzoeksuitkomsten en hypothesen op goede gronden kan worden gekonkludeerd dat met deze uitslag de hypothesen niet zijn gefalsificeerd en als bevestigd kunnen worden beschouwd. Er zal moeten worden nagegaan of de uitkomsten misschien het onbedoelde resultaat zijn van de wijze waarop de variabelen werden gemeten of de concepten geindiceerd zijn. Dok in dit geval zullen de desbetreffende veronderstellingen op hun houdbaarheid moeten worden bekeken.

In deze fase van het onderzoek is er evenwel van af gezien de met de hypothesen overeenstemmende vitkomsten systematisch te konfronteren met konkurrerende uitspraken en redeneringen. Deze uitkomsten worden geaksepteerd als bevestiging van de desbetreffende hypothesen.

De korresponderende proposities worden beschouwd als elementen van een bruikbare theorie, die, zoals in $\S 11.1$ nader wordt uitgewerkt, verdere toetsing verdient.

0.2.1 Bespreking van de toetsingsresultaten voor de onafhankelijke variabelen

Behalve de index normatieve integratie zijn alle variabelen betrokken bij niet- of onvoliedig bevestigde hypothesen. Er is dus alle aanleiding na te gaan of achteraf gezien de meting en/of de keuze van de variabelen (medeloorzaak is van deze uitkomsten.

Wat betreft de onafhankelijke variabelen bleek echter ook bij herhaalde inspektie van de verzamelde gegevens, de berekening van de variabelen en de keuze van de indikatoren geen gegronde reden tot twijfel aan de betrouwbaarheid en geldigheid van de variabelen aanwijsbaar te zijn-dit met vitzondering van de index cijfersproducerende instanties.

Over deze index werd al eerder, in \$ 7.1 , opgemerkt dat daar- 
mee de verscheidenheid aan professionele kontrole- en behandelingsinstanties onvolledig wordt gemeten. Uit het voorafgaande blijkt, dat de index cijfersproducerende instanties als de minst suksesrijke variabele inderdaad problemen oplevert. De verwachte relaties met het \% beroepsbevolking met > lager onderwijs (hypothese 5) en met het agressief gedrag, de vermogensmisdrijven en de agressieve misdrijven (hypothese 12) werden wel, die met het aantal inwoners, de bevolkingsdichtheid, de index economische diversiteit en met het vluchtgedrag, de echtscheidingen en de zelfmoord (hypothesen 2, 3, 4 en 12) werden niet gevonden.

De veronderstelling, dat ondariks de onvolledige meting, de index cijfersproducerende instanties indikatief is voor aantal of omvang van de professionele kontrole instanties zoals bedoeld in het conceptuele model, valt waarschijnlijk niet te handhaven -deze indikator lijkt met, op de politiesterkte na, uitsluitend medische voorzieningen toch te eenzijdig gemeten. Deze eenzijdige meting zou de verklaring kunnen zijn voor de uiteenlopende effekten van de index op de gedragsvariabelen (hypothese 12).

Bij de konstruktie van de index cijfersproducerende instanties kon geen rekening worden gehouden met het feit, dat veel professionele kontrolerende of behandelende instanties, in een zo nu en dan dysfunktioneel ver doorgevoerde arbeidsverdeling, gedragsspecifiek werken.

De index cijfersproducerende instanties omvat enerzijds nauwelijks instanties en de faktor vluchtgedrag anderzijds nauwelijks gedragingen die met elkaar te maken hebben. Wat betreft het vluchtgedrag werden bovendien voor 9 van de 13 hoogladende variabelen, waaronder de echtscheidingen, de gegevens ontleend aan voor alle gemeenten van overheidswege gelijkelijk bijgehouden registraties (burgerlijke stand, verkiezingen, keuringen militaire dienstplicht]. Hoewel de mate van betrouwbaarheid kan verschillen, zijn voor deze gegevens, evenals trouwens voor de zelfmoord, systematisch verschillen in registratiekansen inderdaad minder waarschijnlijk.

Voor de faktor agressief gedrag geldt evenwel dat voor zes van de zeven hoogladende gedragsvariabelen, waaronder de vermogensmisdrijven, de gegevens afkomstig zijn van instanties, die per gemeente naar omvang en aktiviteiten kunnen variëren. Voor deze gegevens kan dus wel sprake zijn van systematische verschillen in registratiekansen. Gelet op de samenhang van de vermogensmisdrijven met de poli- 
tiesterkte, $r=.56(\xi 2.3)$ is het plausibel, dat deze gedragsvariabele, evenals de faktor agressief gedrag positief correleert met de index cijfersproducerende instanties, waarin immers de politiesterkte is opgenomen. Het positieve effekt van de index op de agressieve misdrijven is evenwel niet tot een samenhang van deze gedragsvariabele met de politiesterkte te herleiden ( $r=-.01)$.

Dit alles in aanmerking genomen lijkt het mogelijk te konkluderen, dat hypothese 12 met de bijbehorende veronderstellingen kan worden gehandhaafd mits de relatie wordt onderzocht op geëigende, op gemeenteniveau geregistreerde gedragsvariabelen en de index cijfersproducerende instanties minder eenzijdig, met behulp van meer gegevens over ook andere instanties, die op gemeenteniveau opereren, wordt gemeten. Deze oplossing lijkt verenigbaar met de overeenkomstig de verwachtingen gevonden relatie van de index met het $\%$ beroepsbevolking met > lager onderwijs.

Bovendien is het niet uitgesloten, dat bij een vollediger, meer gedifferentieerde meting de index cijfersproducerende instanties een sterkere positieve samenhang met de index economische diversiteit (hypothese 4) zou kunnen worden gekonstateerd dan nu het geval is $(\beta=.13)$.

Het is echter de vraag of deze oplossing ook een verklaring biedt voor de negatieve uitkomsten voor hypothesen 2 en 3 . Vermoedelijk is hier niet zo zeer sprake van problemen met de variabelen, maar zijn de veronderstellingen rond de hypothesen zelf in het geding.

In hypothese 2 wordt een positieve correlatie van het aantal inwoners met de index cijfersproducerende instanties verondersteld, welke correlatie verwacht wordt in de stedelijke gemeenten hoger te zijn dan in de plattelandsgemeenten. De redenering waarop deze verwachting werd gebaseerd luidt, kort samengevat, dat een toenemend aantal inwoners, zeker in geval van ook een grotere bevolkingsdichtheid, vanwege een grotere interaktiefrekwentie en een daardoor relatief geringere intensiteit van'de interaktie, gepaard gaat met een minder strikte onderlinge kontrole op het individuele gedrag en een grotere behoefte aan professionele en gespecialiseerde instrumenten tot beheersing van het gedrag. De impliciete veronderstelling was dat de instanties die deze beheersingsfunktie vervulien vooral gevestigd zullen worden daar waar deze behoefte het grootst is.

In het licht van de onderzoeksuitkomsten is achteraf gezien 
deze veronderstelling waarschijnlijk niet houdbaar. Evenals trouwens ten aanzien van de arbeidsverdeling (hypothese 1) zullen voor verschillende professionele kontrole instanties de beslissingen over hun vestiging of uitbreiding niet op gemeentelijk, maar op regionaal, provinciaal of zelfs landelijk niveau worden genomen. Indien en voor zover deze beslissingen op andere overwegingen dan de gemeentelijke behoefte aan gedragsbeheersing zijn gebaseerd, is uiteraard een samenhang tussen eigenschappen van de gemeenten die deze behoefte zouden moeten indiceren (zoals bijvoorbeeld het aantal inwoners) en de aanwezigheid en de omvang van de gedragsbewakende instanties niet te verwachten.

Aansluitend aan deze redenering zou ook een verklaring kunnen worden gezocht voor het feit dat, tegen de verwachting in, de bevolkingsdichtheid wel, zij het matig, correleert met de index cijfersproducerende instanties ( $\beta=.24$ voor het totale aantal gemeenten).

Het is namelijk denkbaar, dat in geval van niet op gemeentenieau genomen beslissingen over de vestiging van de hier bedoelde voorzieningen, behalve de mogelijkheid tot het aantrekken van geschoold personeel, ook een zo groot mogelijk bereik van de gedragsbewakende instanties een belangrijk kriterium vormt bij de keuze van de vestigingsplaats. Hierdoor zou zich een tendens tot concentratie van professionele kontrole instanties in dichter bevolkte gemeenten kunnen voordoen. Deze eventuele andere werking van het aantal inwoners op de index cijfersproducerende instanties is enerzijds in overeenstemming met het in hypothese 1 veronderstelde effekt op de index economische diversitejt en anderzijds niet strijdig met de voor hypothese 10 gevolgde redenering over de relatie tussen inwonertal, individuele vrijheid van handelen en typen van afwijkend gedrag. In dit opzicht zou dus wijziging van het model op grond van de anderzoeksresultaten geen problemen opleveren.

Voor de tegenstrijdige uitkomsten voor de variabele \% beroepsbevolking met meer dan lager onderwijs is het moeilijker om een binnen het model passende verklaring te vinden.

De hypothesen 5, 6 en 7 over de relatie van het \% beroepsbevolking met > lager onderwijs met achtereenvolgens de index cijfersproducerende instanties, aantal inwoners en de index economische diversiteit zijn op een identieke redenering gebaseerd: de specialisatie en differentiatie van taken en funkties brengen de noodzaak en mogelijkheid tot een hoger 
opleidingsniveau met zich mee.

De resultaten zijn echter niet identiek. De verwachte relatie met de index cijfersproducerende instanties (hypothese 5) werd wel, die met het aantal inwoners (hypothese 6) nauwelijks en met de index economische diversiteit (hypothese 7) in het geheel niet gevonden.

De verklaring voor deze uiteenlopende uitkomsten zal gezocht moeten worden in problemen met al de impliciete veronderstelling dat elk van deze drie variabelen indikatief is voor de mate van specialisatie en differentiatie van taken en funkties of met b) de veronderstelde werking van deze specialisatie en differentiatie op het opleidingsniveau dan wel cl in een kombinatie van beide mogelijkheden.

Wat betreft de uitkomst voor hypothese 6 zou sprake kunnen zijn van de eerstgenoemde mogelijkheid. Aangezien het inwonertal niet correleert met de indices cijferspraducerende instanties en economische diversiteit is het denkbaar dat anders dan verwacht een groter aantal inwoners niet steeds gepaard gat met een grotere specialisatie en differentiatie van taken of concentratie van bestuurlijke funkties. Daarnaast moet misschien nog in aanmerking worden genomen dat onderwijsvoorzieningen zich meer naar de streekfunktie dan naar de grootte van de gemeenten lijken te spreiden (zie de hoogscorende gemeenten op de faktor onderwijsfaciliteiten, Bijlage VII - 7). Voor de tegengestelde resultaten van de hypothesen 5 en 7 is het moeilijker een plausibele verklaring te vinden. Het is niet goed in te zien warom de index cijfersproducerende instanties als indikator voor een specifieke sektor van de arbeidsverdeling wel volgens verwachting positief correleert met het \% beroepsbevolking met meer dan lager onderwijs (hypothese 5) terwijl de index economische diversiteit als indikator voor de arbeidsverdeling in het algemeen daarmee in tegenstelling tot de verwachting niet positief en zelfs zwak negatief correleert (hypothese 7).

Een nader te onderzoeken mogelijkheid zou kunnen zijn dat enerzijds de gespecialiseerde, professionele gedragsbewakende instanties vrijwel steeds en uitsluitend met (hoog)geschoold personeel werken, doch anderzijds de ontwikkeling van de economische diversiteit in het algemeen ook of misschien zelfs vooral de aanwezigheid van ongeschoolde arbeidskrachten vergt. Deze interpretatie is echter tamelijk speculatief en bovendien niet goed verenigbaar met de voorspelde en gevonden negatieve correlaties van zowel de index econo- 
nomische diversiteit als het $\%$ beroepsbevolking met > lager onderwijs met de index normatieve integratie (hypothesen 8 en 9). Via deze negatieve correlaties met de index normatieve integratie heeft de index economische diversiteit een positieve, zij het indirekte, samenhang met het \% beroepsbevolking met > lager onderwijs. Het is dan ook niet vitgesloten dat de oorspronkelijke relatie (de positieve nulde orde correlatie bedroeg .30) tussen die beide variabelen is onderdrukt door de partialisering naar ondermeer de index normatieve integratie.

Een andere niet bij voorbaat uit te schakelen mogelijkheid is dat hier sprake is van een effekt van verschillen in werk- en woongemeente. In dat geval zouden gemeenten met een relatief grote economische diversiteit fungeren als de werkgemeente voor elders wonend (hoog)geschoold personeel waarvan de scholingsgraad uiteraard niet tot uitdrukking komt in het opleidingsniveau van de in die gemeenten wonende beroepsbevolking.

De overeenkomstig hypothese 9 gevonden negatieve correlatie met de index normatieve integratie, bevestigt overigens de impliciete veronderstellingen over het \% beroepsbevolking met > lager onderwijs als indikator voor de mate van mondigheid, intellektuele ontwikkeling, morele vrijheid van handelen, die geacht worden met een bepaald opleidingsniveau gepaard te gaan.

10.2.2 Bespreking van de toetsingsresultaten voor de afhankelijke variabelen

Afgezien van de hiervoor gemaakte opmerkingen over de keuze van de gedragsvariabelen in verband met de effekten van de index cijfersproducerende instanties is ook achteraf gezien over de betrouwbaarheid en geldigheid van deze variabelen weinig meer te zeggen dan daarover in paragraaf 7.1 al naar voren is gebracht. Het effekt van de politieaktiviteiten op de vermogens- en de agressieve misdrijven is door middel van de relatie met de index cijfersproducerende instanties vastgesteld en gekontroleerd. Daarmee zijn overigens de beide criminaliteitscijfers nog geen representatieve indikatoren voor de desbetreffende misdrijuen, noch wat betreft het feitelijk aantal, noch wat betreft de verscheidenheid waarin deze misdrijven zich voordoen. Zo zal bijvoorbeeld de variabele agressieve misdrijven nauwelijks veroordelingen of seponeringen wegens kinder- of vrouwenmishandeling omvatten. De toevoeging van 
dergelijke misdrijven zou zeer waarschijnlijk de waarde van de variabele agressieve misdrijven als indikator voor op anderen gericht, agressief gedrag verbeteren. Desondanks zijn met name de faktor agressief gedrag en de variabele agressieve misdrijven suksesvol gebleken: alle hypothesen over deze variabelen werden bevestigd, zij het dan dat het verwachte negatieve effekt van het aantal inwoners op de agressieve misdrijven nogal zwak is.

Voor de variabele vermogenemisdrijven werden niet alle hypothesen volledig bevestigd: de relatie met de index normatieve integratie (hypothese 13) is weliswaar in de voorspelde richting, maar zeer laag, terwijl in tegenstelling tot de verwachting (hypothese 11) binnen de categorie plattelandsgemeenten de bevolkingsdichtheid geen negatief, maar een duidelijk positief effekt heeft op deze gedragsvariabele, welk effekt overigens overeenkomstig de verwachting bij de stedelijke gemeenten niet voorkamt.

In kombinatie met Webb's kwalifikatie van vermogensmisdrijven als het resultaat van rationeel en gemotiveerd gedrag en als zodanig een valide indikator voor de normatieve oriëntatie van de dader, doet het zwakke positieve effekt van de index normatieve integratie enige twijfel rijzen aan de eenduidige betekenis van de variabele vermogensmisdrijven als indikator voor illegitiem, op anderen gericht gedrag. Misschien is er sprake van een dubbelzinnige betekenis, waarin althans voor sommige typen van vermogensmisdrijven hogere frekwenties indikatief zijn voor veranderende opvattingen over de individuele eigendom of voor de anonimisering van de eigendom (bijvoorbeeld winkeldiefstal in supermarkten, diefstal van (brom)fietsen, auto's op parkeerterreinen, knoeien met bankcheques, zonder betaling gebruik maken van het openbaar vervoer). Indien en voor zover dit inderdaad het geval is kunnen vermogensmisdrijven niet (meer) worden opgevat als tegen anderen gericht gedrag en gelden dus ook de vooronderstellingen ten opzichte van dat gedrag niet meer. Helaas ontbreken de gegevens -uitsplitsing van de veroordelingen en de seponeringen naar type vermogensmisdrijven- waarmee deze verklaring zou kunnen worden onderzocht.

Dit geldt aok voor de interpretatie van de onverwachte, positieve invloed van de bevolkingsdichtheid op de vermogensmisdrijven.

Deze uitkomst is waarschijnlijk niet zozeer toe te schrijven aan een variabelenprobleem als wel aan een probleem met de hypothese, namelijk aan een andere dan in de hypothese voor- 
ziene werking van de bevolkingsdichtheid.

De juist hogere in plaats van lagere frekwenties van de vermogensmisdrijven (dat wil zeggen van veroordelingen en seponeringen inzake vermogensdeliktenj doet vermoeden dat de grotere ontontdekkingskans, die met een grotere bevolkingsdichtheid in geval van een kleiner aantal inwoners gepaard zou gaan, niet preventief werkt (\$ 6.2, propositie 11), maar veeleer zich manifesteert in relatief grotere aantallen ontdekte en opgeloste vermogensmisdrijven. Gegevens waarmee in het kader van dit onderzoek deze interpretatie op haar mérites zou kunnen worden beoordeeld (zoals bijvoorbeeld de proportie apgelaste vermogensmisdrijven van het aantal bij de politie bekend geworden vermogensdelikten per gemeente, de proportie bekend geworden vermogensdelikten van het totaal aantal gepleegde vermogensdelikten] ontbreken echter.

Er van uitgaande, dat de faktor vluchtgedrag en de variabele echtscheidingen inderdaad als betrouwbaar en geldig gemeten indikatoren mogen worden beschouwd, is de verklaring van de afwijkende uitkomsten voor deze variabelen niet met onmiddelijke evidentie gegeven.

De verwachting van een negatieve samenhang van deze beide gedragsvariabelen met de bevolkingsdichtheid binnen de categorie plattelandsgemeenten berust op de verondersteliing, dat in relatief kleine gemeenten een sterkere concentratie van de bevolking een intensievere sociale interaktie en daardoor een grotere onderlinge kontrole op het gedrag met zich zal brengen, weshalve de vrijheid var handelen er beperkter en de variabiliteit van het gedrag er dus geringer zullen zijn. Het is zonder aanvullend onderzoek moeilijk te bepalen op welke punten de gevolgde redenering korrektie behoeft. Duidelijk is alleen dat de bevolkingsdichtheid niet de verwachte en door het inwonertal gekonditioneerde werking heeft op het vluchtgedrag en de echtscheidingen.

Dit doet enige twijfel rijzen aan de betekenis van het wel overeenkomstig de hypothese gevonden en op dezelfde redenering berustende negatieve effekt van de bevolkingsdichtheid op de variabele zelfmoord. Het is niet erg aannemelijk dat het voorspelde effekt zich in het ene geval niet en in het andere geval wel zou manifesteren. Het lijkt verstandig hier rekening te houden met de mogelijkheid van een andere dan de voorspelde werking van de bevolkingsdichtheid: niet de geringere vrijheid van handelen, maar de grotere intensiteit van de sociale interaktie veroorzaakt een negatief effekt op het zelfmoordcijfer. 
In deze verklaring zou de bevolkingsdichtheid, onder de konditie van een relatief gering aantal inwoners, als indikatief voor de sterkte van de sociale integratie kunnen worden beschouwd. Daarmee zou de verklaring kunnen aansluiten bij een eveneens op Durkheim teruggrijpende traditie waarin een etiologische interpretatie wordt gegeven van de relatie tussen de mate van sociale integratie en de zelfmoord ( $\$ 4.2$, voetnoot 1 ).

Deze interpretatie is verenigbaar met de in feite ook bevestigde verwachting (hypothese 11b), dat vanwege het relatief grotere aantal inwoners en de daarmee gepaard gaande geringere intensiteit van de interaktie, binnen de categorie stedelijke gemeenten het negatieve effekt van de bevolkingsdichtheid op de zelfmoord van weinig betekenis meer zal zijn. De verklaring is eveneens in overeenstemming met hypothese 10 , waarin vanwege de geringere onderlinge kontrole op het gedrag en de daardoor grotere vrijheid van handelen (of als alternatief: zwakkere sociale integratie) een positief effekt van het aantal inwoners op de zelfmoord, alsook op het vluchtgedrag, de echtscheidingen en de vermogensmisdrijven en een negatief effekt op de agressieve misdrijven wordt voorspeld. Een komplicerende faktor is dat hypothese 10 voor alle gedragsvariabelen werd bevestigd, met uitzondering van nu juist de zelfmoord. In plaats van een positief effekt is bij de plattelandsgemeenten en de stedelijke gemeenten sprake van een negatief effekt op de zelfmoord. Hoewel dit resultaat zich laat verenigen met de konstatering van Kruyt (1960), dat bezien over de periode 1900-1950 het zelfmoordverschijnsel in tegenstelling tot in andere landen in Nederland een vitgesproken plattelandskarakter heeft, draagt het weinig bij tot een in het model passende opheldering van de relaties van het aantal inwoners en de bevolkingsdichtheid met het zelfmoordcijfer. Alles bijeengenomen kan worden vastgesteld dat de werking van met name de bevolkingsdichtheid dan wel de kondities van deze werking op de gedragsvariabelen waarschijnlijk gevarieerder zijn dan in het model werd voorzien, over welke vraag zonder aanvullende gegevens geen verstandige uitspraken te doen zijn.

\subsubsection{Bespreking van de niet-voorspelde resultaten}

Indien wordt afgezien van de onderlinge relaties tussen de gedragsvariabelen, zijn er tussen de variabelen van het model 23 mogelijke samenhangen waarover geen expliciete hypothese werd geformuleerd. 
Deze niet-voorspelde relaties zijn natuurlijk niet allen even belangrijk. Ook de redenen waarom geen hypothese werd geformuleerd lopen uiteen.

Zo had het bijvoorbeeld geen nut een uitspraak te doen over het effekt van de bevolkingsdichtheid op de gedragsvariabelen, dat voor het totale aantal gemeenten te verwachten zou zijn, omdat in hypothese 11 voor de plattelandsgemeenten wel en voor de stedelijke gemeenten. geen of zelfs tegengestelde effekten worden voorspeld. Zoals eigenlijk al viel te verwachten, blijken in feite de voor het totale aantal gemeenten berekende, overigens lage, correlaties overwegend de gevonden effekten in de plattelandsgemeenten te weerspiegelen.

Iets dergelijks geldt voor de mogelijke relaties van het aantal inwoners en de bevolkingsdichtheid met de faktor agressief gedrag. Over deze relaties konden geen uitspraken worden gedaan omdat enerzijds op deze faktor zowel de vermogensmisdrijven als de agressieve misdrijven hoog laden, terwijl anderzijds in de hypothesen 10 en 11 voor deze beide gedragsvariabelen tegengestelde relaties met het inwonertal en de bevolkingsdichtheid worden voorspeld.

De gevonden correlaties met de faktor agressief gedrag weerspiegelen trouwens die met de afzonderlijke criminaliteitsvariabelen ( tabel 11b).

De mogelijke relaties van achtereenvolgens het aantal inwoners, de bevolkingsdichtheid en de index cijfersproducerende instanties met de index normatieve integratie zijn van groter belang. In de gedachtengang, gevolgd in het model, gaat het met deze relaties immers om de eventuele samenhang tussen de gedrags bewakende en de gedragsregulerende aspekten van de sociale beheersing.

Over deze samenhang werden geen hypothesen geformuleerd, omdat zowel voor positieve als voor negatieve correlaties een plausibele redenering opgebouwd kan worden. De mate van normatieve integratie en de behoefte aan gedragskontrole kunnen namelijk gelijk op, maar ook tegengesteld variëren. Zo is het denkbaar, dat een sterke normatieve integratie gepaard gaat met ook een hoge mate van gedragskontrole, terwijl het zich omgekeerd ook laat denken dat juist verzwakking van de normatieve integratie leidt tot een grotere behoefte aan, vooral professionele, gedragskontrole.

Blijkens de berekende correlaties (paragraaf 8.4 ) doen zich in feite tussen de genoemde variabelen en de index normatieve integratie geen samenhangen van betekenis voor -een uitkomst die 
zou kunnen doen vermoeden dat de gedragsbewakende en de gedragsregulerende aspekten van de sociale beheersing onafhankelijk van elkaar variëren. Voordat over deze op zich interessante mogelijkheid in het kader van het model hypothesen ontwikkled kunnen worden, zal toch echter eerst de reden voor deze onafhankelijke variatie van de beide beheersingsaspekten nader onderzocht moeten worden. Ditzelfde geldt, zeker gezien de in het voorafgaande gemaakte opmerkingen, trouwens ook de vooronderstelde geldigheid van het aantal inwoners, de bevolkingsdichtheid en de index cijfersproducerende instanties als indikatoren voor de gedragsbewakende aspekten van de sociale beheersing.

Tenslotte nog enkele opmerkingen over de niet-voorspelde effekten van het \% beroepsbevolking met meer dan lager onderwijs en de index economische diversiteit op de gedragsvariabelen.

Wat betreft het \% beroepsbevolking met > lager anderwijs werd eerder ( $\$$ 9.4) al gekonstateerd dat, althans voor het totale aantal gemeenten, alleen ten aanzien van de agressieve misdrijven sprake is van een duidelijk, negatief effekt, een effekt, dat zelfs nog iets sterker is dan dat van de index normatieve integratie.

Deze bevinding, dat naast een sterkere normatieve integratie ook een relatief laag opleidingsniveau van de (beroeps)bevolking gepaard gaat met hogere cijfers voor agressieve misdrijven, onderstreept het belang van de mondigheid, de individuele ontwikkeling, de morele vrijheid van handelen als faktoren in het voorkomen en de spreiding van agressieve criminaliteit. Deze uitkomst biedt echter niet voldoende houvast om in het kader van het model ten aanzien van ook de andere gedragsvariabelen een expliciete hypothese over de invloed van het opleidingsniveau te formuleren.

Hoewel daarover geen expliciete hypothese in het model werd opgenomen, worden toch voor de index economische diversiteit uitdrukkelijk geen direkte relaties met de gedragsvariabelen verwacht. In paragraaf 9.4 werd vastgesteld dat slechts in enkele gevallen tegen deze verwachting in toch sprake is van een, overigens nogal zwak, rechtstreeks effekt. Wat daarbij opvalt is, dat anders dan bij de correlaties met het \% beroepsbevolking met > lager onderwijs, de richting van de correlaties van de faktor agressief gedrag en van de beide criminaliteitsvariabelen met de index economische diversiteit niet in overeenstemming is met de redenering die in het model ten aanzien 
van de werking van deze index wordt gevolgd. Op het eerste gezicht lijken de positieve correlaties -hogere mate van economische diversiteit gaat gepaard met tendens tot hogere frekwenties van agressief gedrag- strijdig met de uitkomsten voor de hypothesen 8 en 13: hogere mate van economische diversiteit leidt tot zwakkere normatieve integratie, zwakkere normatieve integratie gaat gepaard met lagere frekwenties van agressief gedrag.

Voor deze ogenschijnijjk onverenigbare uitkomsten is echter wel een plausibele verklaring te geven. Het is namelijk zeer wel denkbaar, dat de strijdigheid in vitkomsten indikatief is voor een faseverschil in het voorspelde proces waarin een toenemende economische diversiteit via een verzwakkende normatieve integratie zou leiden tot afnemende frekwenties van agressief gedrag.

Aangenomen dat enerzijds een hoge mate van normatieve integratie gepaard gat met ook relatief hoge frekwenties van agressief gedrag en dat anderzijds een toenemende economische diversiteit niet van de ene dag op de andere zal leiden tot een verzwakking van de normatieve integratie, is het inderdaad mogelijk, dat in gemeenten met een relatief sterke normatieve integratie een toenemende economische diversiteit en relatief hoge frekwenties van agressief gedrag tegelijkertijd voorkomen.

In dat geval zijn de gevonden relaties van de index economische diversiteit met de faktor agressief gedrag, de vermogensmisdrijven en de agressieve misdrijven dus niet in strijd met de beide kernhypothesen ( 8 en 13) van het model, maar te beschouwen als een gevolg van de transversale meting van de variabelen.

10.3 Evaluatie en konklusies: naar een algemene theorie over de relatie tussen eigenschappen van de sociale beheersing en typen van afwijkend gedrag

De uitkamsten van het onderzoek hebben in de eerste plaats betekenis voor de evaluatie van het conceptuele model en de daaraan ten grondslag liggende uitspraken van Durkheim. Daarnaast zijn de onderzoeksresultaten ook van belang voor de evaluatie van de veronderstellingen over het model en het onderzoek van Webb. Het onderhavige model werd naar aanleiding van zijn onderzoeksuitkomsten en van de daarover geformuleerde veronderstellingen ontwikkeld en het heeft dus zin in dit opzicht de betekenis van de toetsingsresultaten te bepalen. Om te beginnen zijn deze resultaten van belang ten aanzien 
van de konkurrerende verklaringen voor de teleurstellende uitkomsten van Webb's onderzoek.

Zoals medegedeeld in paragraaf 5.3 .1 noemt webb zelf als belangrijkste oorzaken de relatief geringe spreidingsbreedte van zijn variabelen, teweeggebracht door de beperking van zijn onderzoekspopulatie naar gemeente-grootte en de transversale meting van deze variabelen. Mede op grond van een nadere beschouwing van uitspraken van Durkheim warop ook webb zijn model had gebaseerd, werd echter verondersteld dat a) de beperking van zijn model door weglating van de normatieve integratie (\$ 5.3.3) en b) de keuze van zijn kriteriumvariabelen ( $\$ 5.3 .4$ ) belangrijkere faktoren zijn voor de verklaring van zijn uitkomsten.

Deze veronderstelling blijkt dus juist. In dit onderzoek zijn de direkte effekten van de index normatieve integratie op de gedragsvariabelen aanzienlijk sterker dan de direkte effekten van de diversiteitscoëfficiënt bedrijfstakken op de kriteriumvariabelen in het model van Webb. Bovendien blijkt in dit onderzoek niets van een konditionering van deze effekten door een beperkte spreidingsbreedte van de variabelen $\left\{\begin{array}{l}\xi \\ 9.4\end{array}\right)$.

Tenslotte kan worden gekonstateerd dat in dit onderzoek de transversale meting van de variabelen het vinden van duidelijke correlaties niet heeft belemmerd. Hoewel strikt genomen geen bewijs voor het procesmatige karakter van de geponeerde relaties, biedt deze omstandigheid wel steun aan de veronderstelling dat het in de tijd verlopende causale proces geldig geindiceerd kan worden met de tengevolge van faseverschillen en ongelijke uitgangssituaties ontstane verschillen in ruimtelijke spreiding op een bepaald tijdstip van de verschijnselen, die bij dit proces zijn betrokken.

Naar aanleiding van deze veronderstelling over de bruikbaarheid van een transversale meting werd als belangrijke konditie, waaronder de geponeerde relaties van het madel zullen gelden, gesteld dat deze relaties betrekking hebben op eigenschappen van gemeenten die deel uitmaken van een samenleving die zich als zodanig kenmerkt door een relatief hoog-ontwikkelde arbeidsverdeling ( $\$ 5.3 .2$ ).

Behalve voor de reikwijdte van de uitspraken die op grond van het model kunnen worden gedaan, heeft deze konditie ook gevolgen voor het model zelf. Deze gevolgen werden als uitbreiding of wijziging van het model van Webb geformuleerd in propositie 14 (in geindustrialiseerde samenlevingen met 
een sterk ontwikkelde arbeidsverdeling zijn de lokale gemeenschappen onderhevig aan een voor die samenleving als geheel geldende tendens tot een toenemende variabiliteit van het gedrag) en in propositie 1 (in samenlevingen met een relatief hoog ontwikkeld systeem van arbeidsverdeling wordt de verdere ontwikkeling daarvan door andere faktoren dan het sociale volume en de fysieke dichtheid bepaald).

Beide proposities werden door de uitkomsten van dit onderzoek bevestigd. Deze resultaten wettigen de konklusie, dat de hier besproken, direkt dan wel indirekt aan het model en het onderzoek van Webb ontleende, veronderstellingen een verbeterd uitgangspunt bieden voor de vorming van een theorie over de relatie tussen eigenschappen van de sociale beheersing en het voorkomen van bepaalde typen van afwijkend gedrag en dat ze derhalve als bruikbare uitspraken gehandhaafd kunnen worden. De evaluatie van de uitkomsten voor het volledige conceptuele model en van de daaraan ten grondslag liggende uitspraken van Durkheim kan vanuit hetzelfde gezichtspunt worden ondernomen.

De uitkomsten voor het conceptuele model worden in schema 4 nogmaals kort samengevat.

Schema 4

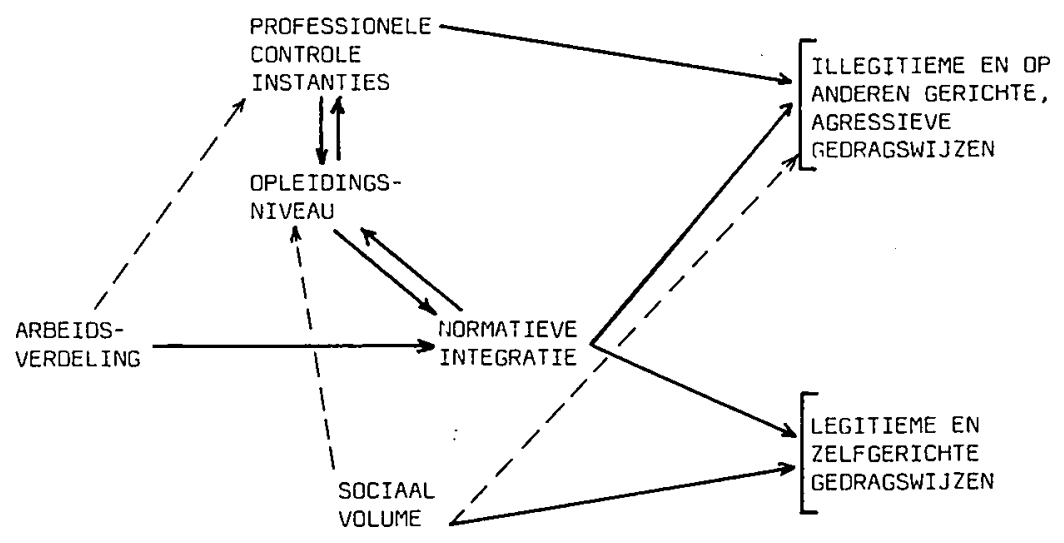

$\longrightarrow$ Voorspelde en empirisch volledig bevestigde relaties.

$--\rightarrow$ voorspelde en empirisch gedeeltelijk bevestigde relaties. 
Uitgaande van het onderscheid tussen de gedragsbewakende en de gedragsregulerende aspekten van het sociale beheersingssysteem (paragraaf 4.2) moet worden gekonkludeerd, dat het conceptuele model wat betreft de gedragsbewakende aspekten slechts gedeeltelijk bruikbaar is.

Zoals schema 4 laat zien, blijken niet alle proposities die op de gedragsbewakende aspekten van de sociale beheersing betrekking hebben zonder meer gehandhaafd te kunnen worden. Deze konklusie geldt niet alleen voor proposities over effekten op de onderscheiden typen van afwijkend gedrag (11 en 12), maar ook voor proposities over hun onderlinge relaties ( 2 en 3 ).

De redenen waarom de korresponderende hypothesen niet of niet volledig werden bevestigd hebben vermoedelijk te maken deels met de meting van de variabelen of de operationalisering van de concepten, deels met de werking van de faktoren, de mechanismen van de relaties. In het eerste geval betekenen de onderzoeksuitkomsten, dat nieuwe aandacht, inventiviteit en eventueel aanvullend onderzoek besteed zal moeten worden aan de keuze van de (nieuwe) variabelen en van de te verzamelen gegevens. In het tweede geval echter impliceren de uitkomsten de noodzaak tot herziening van het model en tot bezinning op de betekenis van de concepten. Dit betreft met name de fysieke dichtheid. De onderzoeksresultaten voor de variabele bevolkingsdichtheid doen enige twijfel rijzen aan het nut van dit concept voor het model, dit te meer omdat voor het aantal inwoners wel de verwachte effekten op de gedragsvariabelen konden worden vastgesteld. Gezien deze uitkomsten zal bij een herziening van het model aandacht besteed moeten worden aan de vraag of het nodig is om naast het sociale volume ook de fysieke dichtheid in het model op te nemen teneinde de door Durkheim bedoelde eigenschappen en werking van de gedragsbewakende aspekten van de sociale beheersing $(\xi 5.1 .2$ ) aanwezig te stellen. Evenals de onderzoeksuitkomsten en de gevolgtrekkingen van Webb impliceert deze konklusie, dat de uitspraken van Durkheim over de betekenis van de fysieke dichtheid voor de funktionele differentiatie van het economische systeem en voor de beheersing van het gedrag niet houdbaar zijn gebleken.

Een geheel andere konklusie kan worden getrokken ten aanzien van Durkheim's uitspraken over de werking van de arbeidsverdeling op de normatieve integratie van de gemeenschap en de daarmee samenhangende variabiliteit van het gedrag. 
Alle proposities (8, 9 en 13), die op deze uitspraken zijn gebaseerd, kunnen worden gehandhaafd. Wat betreft de gedragsregulerende aspekten van de sociale beheersing is het model dus suksesvol gebleken. In dit opzicht vormt het een bruikbare basis voor de verdere ontwikkeling van een theorie waarin verschillen in spreiding en typen van afwijkend gedrag worden verklaard uit eigenschappen van de sociạle beheersing. In dit verband kan nog worden opgemerkt dat, gelet op de verschillen in percentages verklaarde variantie, de verklaringskracht van het model niet voor alle gedragswijzen gelijk is. De bijdrage van het model aan de verklaring van de spreidingsverschillen van de legitieme gedragswijzen, die vitdrukking zijn van een relatief grote variabiliteit van het gedrag is aanzienlijk groter dan zijn bijdrage aan de verklaring van verschillen in spreiding van de illegitieme gedragswijzen, die samenhangen met een relatieve beperking van de beschikbare gedragsalternatieven.

Hoewel deze laatstgenoemde bijdrage van het model zeker niet onbelangrijk is, behoeft toch met name de spreiding van de illegitieme, agressieve gedragswijzen aanvullende verklaring.

Tot slot van dit hoofdstuk kunnen de konklusies over de betekenis van de uitkomsten van het onderzoek als volgt kort worden samengevat.

Over de effekten van de gedragsbewakende eigenschappen van het sociale beheersingssysteem op de spreiding van de onderscheiden gedragswijzen kunnen geen eenduidige uitspraken worden gedaan -de desbetreffende proposities konden niet allen volledig worden gehandhaafd.

De proposities over de effekten van de gedragsregulerende aspekten van de sociale beheersing konden wel volledig worden gehandhaafd.

Dit betekent, dat de uitspraken van Durkheim over de ontwikkeling en de gevolgen van de arbeidsverdeling voor de kollektieve morele consensus en de daarmee samenhangende variabiliteit van het gedrag zich niet alleen laten transformeren tot een toetsbaar model, maar bovendien een empirische toetsing doorstaan.

De bewerkte en getoetste uitspraken vormen de basis voor een algemene, dat wil zeggen in principe ook op andere sociale eenheden dan gemeenten toepasbare theorie waarin, althans binnen hoog-geindustrialiseerde, judeo-christelijke samenlevingen: 
- Bepaalde typen deviant gedrag met vrucht kunnen worden gevat in de categorieën van legitieme, zelf-gerichte gedragsalternatieven versus illegitieme, op anderen gerichte, agressieve gedragswijzen.

- De beschikbaarheid van legitieme gedragsalternatieven, dat wil zeggen de variabiliteit van het gedrag, wordt gezien als uitdrukking van een morele vrijheid van handelen, van mondigheid van het individu, van afwezigheid van een collectieve surveillance, kortom van de morele en sociale vrijheid van keuze van het best-passende gedrag.

- Het voorkomen van illegitieme, op anderen gerichte, agressieve gedragswijzen wordt beschouwd als gevolg van het ontbreken van een gemeenschappelijk erkende morele en sociale vrijheid voor de keuze van het best-passende gedrag.

- De morele en sociale vrijheid voor de keuze van het gedrag verondersteld wordt samen te gaan met de mogelijkheid tot de keuze van een eigen moreel en sociaal referentiekader.

- De mogelijkheid tot de keuze van een eigen moreel en sociaal referentiekader afhankelijk wordt gesteld van de mate van heterogeniteit, pluriformiteit, bindingskracht en consistentie van het normen- en waardensysteem alsook van het opleidingsniveau de betrokken gemeenschappen.

- Tenslotte deze eigenschappen van het normen- en waardensysteem, dat wil zeggen, een relatief geringe mate van normatieve integratie, worden beschouwd als de effekten van een relatief hoog kennisniveau, van een hoge interaktiefrekwentie en van een relatief hoge mate van diversiteit van sociaal-economische belangen, van economische aktiviteiten en van funktionele relaties. 
11. SUGGESTIES VOOR DE VERDERE TOETSING EN ONTWIKKELING VAN DE THEORIE

Naar goed gebruik wordt dit onderzoeksverslag afgesloten met enkele suggesties voor voortgezet onderzoek.

Om te beginnen kan worden gewezen op de evidente noodzaak om met behulp van nieuwe gegevens en aanvullend onderzoek het model op een aantal punten te verbeteren en gevonden relaties op te helderen. Hierbij gaat het al om een verbeterde operationalisering van het concept professionele kontrole instanties en een preciezere meting van de vermogensmisdrijven en de agressieve misdrijven, b) om opheldering over de werking van een aantal variabelen, waaronder het \% beroepsbevolking met > lager onderwijs en c) over de geldigheid van het aantal inwoners, de bevolkingsdichtheid en de index cijfersproducerende instanties als indikatoren van de gedragsbewakende aspekten van de sociale beheersing.

Daarnaast is echter ook onderzoek nodig voor de verdere toetsing van het model en de ontwikkeling van de theorie. Hiervoor zijn verschillende mogelijkheden te bedenken.

11.1 Herhaalde toetsing van het model

Wat de verdere toetsing van het model betreft doen zich in hoofdzaak twee mogelijkheden voor:

- herhaling van het onderzoek op dezelfde populatie

- herhaling van het onderzoek op andere populaties.

In deze paragraaf worden beide mogelijkheden nader toegelicht.

Voor de herhaling van het onderzoek op dezelfde onderzoekspopulatie zou voor de onafhankelijke variabelen van het model gebruik gemaakt kunnen worden van gegevens uit de $12 \mathrm{e}$ Algemene Volkstelling van 1947 en van de in 1977 ter beschikking gekomen gegevens van de $14 \mathrm{e}$ Algemene Volkstelling in 1971.

Voor de gedragsvariabelen zijn over de jaren rond 1971 hoogst waarschijnlijk wel gegevens te verkrijgen. Het is echter zeer de vraag of er ook gegevens voor de jaren rond 1947 te vinden zijn.

Het ontbreken van de benodigde gegevens over afwijkend gedrag voor de periode rond 1947 zou betekenen, dat alleen op de gegevens van 1971 een transversale analyse kan worden uitgevoerd om te onderzoeken of de correlaties tussen (de transversaal gemeten) variabelen overeenstemmen met de in het model voor- 
spelde of in het onderzoek voor de jaren rond 1960 gevonden samenhangen.

Met deze analyse zou de generaliseerbaarheid van het model in de tijd kunnen worden onderzocht.

Het lijkt verstandig de variabelen voor het herhaalde onderzoek, ondanks de in sommige gevallen daaraan verbonden bezwaren, als het enigszins kan op dezelfde wijze, dat wil zeggen met dezelfde gegevens te meten, zodat de vergelijking met de uitkomsten voor 1960 zo zuiver mogelijk is.

Indien en voor zover de hiervoor genoemde verbeteringen en preciseringen van de metingen mogelijk blijken te zijn, zouden ook de correlaties tussen de verbeterde en gepreciseerde variabelen berekend moeten worden, zodat kan worden nagegaan of de gewenste en veronderstelde effekten zich inderdaad voordoen.

In de tweede plaats kan met behulp van de gegevens voor 1947 , 1960 en 1971 het model longitudinaal worden onderzocht. Omdat bij de longitudinale analyse de veranderingen in de waarden van de variabelen moeten kunnen worden bepaald is een identieke meting van de variabelen 1947, 1960 en 1971 uiteraard noodzakelijk. Hierbij kan zich dus het probleem voordoen van een inmiddels gebleken beter resultaat van een eventueel gewijzigde meting van de variabelen 1947 en/of 1971.

Er van uitgaande dat dit probleem bevredigend kan worden opgelost, bijvoorbeeld door alsnog de desbetreffende variabelen 1960 gewijzigd te meten, kunnen met de longitudinale meting verschillende vragen en veronderstellingen worden onderzocht.

Door middel van vergelijking van de waarden van de desbetreffende variabelen 1947, 1960 en 1971 zou informatie kunnen worden verkregen over zowel de voortgang als de spreiding van de onderscheiden processen (toenemende arbeidsverdeling, toenemende professionele kontrole, stijgend opleidingsniveau etc.).

Zo kan worden vastgesteld of:

- de voortgang van de processen, zoals gemeten over de perioden 1947-1960 en 1960-1971 gelijkmatig en voor alle verschijnselen dezelfde is, dat wil zeggen de gemiddelde waardeveranderingen van de betrokken variabelen proportioneel vergelijkbaar groot zijn.

- de gemeenten in gelijke mate bij de processen zijn betrokken, dat wil zeggen de waardeveranderingen per variabele 
voor alle gemeenten proportioneel vergelijkbaar groot en in dezelfde richting zijn.

In geval van een ongelijke voortgang en/of een ongelijke spreiding zal aandacht besteed moeten worden aan de betekenis en de eventuele effekten van de voortgangsverschillen tussen de verschijnselen en/of de spreidingsverschillen tussen de gemeenten.

Deze kwestie is van belang in verband met de vraag naar de causaliteit van de relaties.

Een belangrijk aspekt van de herhaalde metingen van de variabelen in 1947, 1960 en 1971 is de mogelijkheid de causaliteit van de geponeerde relaties te onderzoeken, dat wil zeggen de tijdsvolgorde in de waardeveranderingen van de desbetreffende variabelen te bepalen.

Zo zou bijvoorbeeld kunnen worden nagegaan of een grotere economische diversiteit in 1947 gepaard gat met een over de periode 1947-1960 afnemende normatieve integratie en een over de periode 1947-1960 afgenomen normatieve integratie samengat met over de periode 1960-1971 gemeten toegenomen frekwenties van legitieme, zelf-gerichte gedragswijzen enerzijds en afgenomen frekwenties van illegitieme, agressieve, op anderen gerichte gedragswijzen anderzijds.

Het grootste rendement van de herhadide metingen voor de 176 gemeenten (of voor zoveel gemeenten als daarvan na samenvoegingen en opheffingen gedurende de periode $1960-1971 \mathrm{zijn}$ overgebleven) zal zijn gelegen in de beantwoording van deze en dergelijke vragen.

Indien en voor zover die vragen bevestigend zouden kunnen worden beantwoord, zou aan het model voorspellende waarde toegekend kunnen worden.

Daarnaast kan nog aandacht worden besteed aan de faseverschillen, die zich in de causale relaties kunnen voordoen en die in paragraaf 10.2.3 werden aangevoerd als verklaring van de gevonden samenhangen tussen de index economische diversiteit en een aantal gedragsvariabelen. Behalve voor de toetsing van deze interpretatie is de vraag naar faseverschillen in het causale proces ook methodologisch van belang in verband met de eerder genoemde ( $\$ 1.2$ en $\$ 5.3 .1$ ) 'fallacy of the time lag' die met de transversale meting van causaal gerelateerde verschijnselen kan worden begaan.

Dit betekent tenslotte, dat met de hier gesuggereerde longitudinale onderzoeksopzet ook de veronderstelling kan worden getoetst waarop het onderzoek werd gebaseerd, namelijk dat 
het in de tijd gespreide causale proces geldig kan worden geĩndiceerd met de ruimtelijke spreiding op een bepaald tijdstip van de bij dit proces betrokken verschijnselen. Wat betreft de toetsing van het model door middel van herhaling van het onderzoek op andere populaties doen zich in principe vele mogelijkheden voor.

De eerste en meest reële mogelijkheid bestaat uit de uitbreiding van het onderzoek over alle Nederlandse gemeenten, waardoor ook gegevens van de gemeenten met minder dan 5000 inwoners en van de vier grootste gemeenten bij de analyse zouden kunnen worden betrokken.

De verzameling van de benodigde en ook beschikbare gegevens voor alle Nederlandse gemeenten kost waarschijnlijk althans naar verhouding weinig extra moeite, terwijl toch kan worden onderzocht of de reikwijdte van het model groter is dan de aanvankelijk geselekteerde subpopulatie.

In verband met de bepaling van de reikwijdte van het model veel interessantere populaties worden gevormd door de gemeenten van andere landen die voldoen aan de konditie waaronder het model geacht wordt te gelden, namelijk hoog-geindustrialiseerd met een ver-ontwikkelde arbeidsverdeling. Hier kan worden gedacht aan onderzoek op gemeenten uit België, Duitsland, Frankrijk en Engeland.

Het valt echter te voorzien dat bij de realisering van dergelijke, op zich routinematige onderzoekingen, zich grote problemen zullen voordoen bij de operationalisering van de concepten en de meting van de variabelen. Indien al identieke of op zijn minst vergelijkbare gegevens voor de gemeenten uit een ander westers land of voor een omschreven selektie daarvan, kunnen worden verkregen, dan blijft de vraag naar de al dan niet identieke betekenis van deze gegevens -een in verband met hun geldigheid als indikatoren voor de concepten niet onbelangrijk gegeven.

Deze problemen ten aanzien van de beschikbaarheid, vergelijkbaarheid en validiteit van de gegevens zullen zich in zo mogelijk nog versterkte mate voordoen in onderzoekingen, waarin ook de konditie voor de geldigheid van het model getoetst zou kunnen worden.

Hierbij valt te denken aan onderzoek op gemeenten of vergelijkbare geografisch-bestuurlijke eenheden uit niet-christelijke en/of overwegend agrarische landen of aan onderzoek op een populatie van landen, welke populatie dan zowel judeochristelijke en hoog-geindustrialiseerde als niet-christelijke 
en laag-geindustrialiseerde landen zou moeten omvatten. Ondanks de daaraan verbonden praktische bezwaren zou het vanwege het hoge rendement dat een geslaagde poging voor de status van de theorie zou kunnen opleveren, de moeite waard zijn de mogelijkheden voor dergelijke onderzoekingen nader te exploreren. Daarbij zou eventueel overwogen kunnen worden te werken met aangepaste operationele modellen. Ditzelfde geldt overigens ook ten aanzien van een andere, minstens even interessante, populatie waarop het model en de reikwijdte ervan getoetst zou kunnen worden. Het betreft hier de buurten of wijken van Nederlandse gemeenten. Het probleem voor deze populatie is waarschijnijik niet zozeer een ongelijke of onzekere betekenis van de gegevens, maar veeleer de omstandigheid dat een groot deel van de gegevens, zeker in de kleinere gemeenten niet op het niveau van buurten of wijken wordt geregistreerd.

Daarbij komt nog dat in veel sterkere mate dan bij de gemeenten reeds het gevai is, de onderscheiden processen en verschijnselen veelal de grenzen van een buurt overschrijden. In concreto kan dit bijvoorbeel.d betekenen dat de beroepsbevolking van een buurt in verschillende andere buurten werkzaam is. Toch lijkt het ook in dit geval de moeite waard na te gaan of, desnoods alleen voor de grotere gemeenten en met behulp van een aangepast operationeel model, een toetsing van het model op het niveau van buurten of wijken tot de mogelijkheden behoort Indien deze mogelijkheid tot toetsing op wijkniveau zich voor een groter aantal gemeenten zou voordoen, dan zou daarmee tevens de mogelijkheid tót een multi-niveauanalyse zijn gegeven. Indien en voor zover deze mogelijkheid zich zou voordoen, zou het desbetreffende onderzoek behalve een herhaalde toetsing van het model en een bepaling van de reikwijdte van de theorie ook informatie kunnen opleveren over de eerder, in paragraaf 2.3 gestelde vraag naar de konsistentie van relaties tussen variabelen, gemeten aan eenheden op verschillende niveaus van analyse -een probleem dat vanwege zijn konsekwenties voor de vertaling van zowel theorieën ('fallacy of displaced scope') als correlaties ('ecological fallacy') naar verschillende niveaus op zich reeds waard is onderzocht te worden. Behalve op populaties van bestuurlijk-geografische eenheden als gemeenten en buurten zouden de geldigheid en de reikwijdte van de theorie in principe ook op andersoortige populaties onderzocht kunnen worden. Hierbij valt bijvoorbeeld te denken aan bedrijven en/of afdelingen binnen bedrijven. Hoewel bij 
dergelijke populaties zeker met aangepaste operationele modellen zou moeten worden gewerkt, laat het zich zeer wel denken dat ook bedrijven worden gekenmerkt door een eigen mate van sociaal volume, fysieke dichtheid, arbeidsverdeling, opleidingsniveau van de werknemers, normatieve integratie. Dat ze zich kenmerken door een eigen frekwentie of type van afwijkend gedrag, zoals bijvoorbeeld ziekteverzuim werd al eerder gekonstateerd (Philipsen, 1969).

Hoewel de operationalisering in bedrijfskenmerken van sommige concepten waarschijnlijk problemen zal geven, zou het een interessante gelegenheid zijn om bij de meting van bijvoorbeeld het concept normatieve integratie ook andere aspekten te kunnen betrekken, zoals arbeidsmoraal, gezagsverhoudingen e.d.

Het zal witeraard niet mogelijk zijn dit gehele onderzoeksprogramma systematisch af te werken. De mogelijkheden lijken echter toch interessant genoeg om althans voor een enkele daarvan een poging tot realisering te wagen.

11.2 Ontwikkeling van de theorie: funktionele interdependentie en de invariabiliteit van het gedrag

In deze paragraaf zal geen poging worden ondernomen tot verbetering of uitbreiding van het model, gericht op een groter verklarend vermogen in termen van hogere percentages verklaarde variantie.

In het vorige hoofdstuk werd gekonstateerd dat, gezien de relatief lage percentages verklaarde variantie van de desbetreffende gedragsvariabelen, met name de spreiding van illegitieme, agressieve gedragswijzen aanvullende verklaring behoeft ( $\$ 10.1$ en § 10.3). Deze konstatering zou op zich aanleiding kunnen zijn tot uitbreiding van het model met faktoren die tot een aanvullende verklaring zouden kunnen bijdragen. Daarbij zou kunnen worden gedacht aan andere, materiële gedragsbeperkende faktoren zoals bijvoorbeeld inkomensniveau, aan etiologische faktoren als snelle en relatief sterke bevolkingsgroei, invasie ethnische minderheidsgroepen, woningtekort en verkrotting, werkeloosheid e.d. en aan eigenschappen van de populatie, die met illegitiem en agressief gedrag samenhangen, zoals bijvoorbeeld leeftijdsen geslachtsverdelingen. Hier wordt echter afgezien van enige uitwerking van deze mogelijke uitbreiding van het model omdat:

- een volledige of zo volledig mogelijke verklaring van de spreiding van de onderscheiden vormen van afwijkend gedrag 
nooit het doel van het model is geweest;

- de toevoeging van deze of dergelijke faktoren het model zowel wat betreft de onderlinge relaties van de concepten als aangaande hun relatieve bijdragen aan de verklaring van de spreidingsverschillen van de onderzochte gedragswijzen in hoge mate zou kompliceren;

- de toevoeging van de hier genoemde faktoren, andanks de eventueel hogere percentages verklaarde variantie, vermoedelijk weinig zou bijdragen aan de reeds bestaande kennis over ontstaan en spreiding van illegitieme, agressieve gedragswijzen en dus niet zo interessante is;

- de toegevoegde faktoren niet of nauwelijks uit het getoetste model zouden zijn afgeleid.

11.2.1 Durkheim's toekomstvisie als aanknopingspunt voor de verdere ontwikkeling van de theorie

In deze slotparagraaf zal wel aandacht worden besteed aan de mogelijkheid het model verder te ontwikkelen op grond van een doordenking van de logische en empirische konsekwenties van de redenering warop het is gebaseerd.

Omdat deze rédenering in belangrijke mate berust op uitspraken van Durkheim, ligt het voor de hand na te gaan of en in welk opzicht bij Durkheim ook aanknopingspunten voor een verdere ontwikkeling van het model te vinden zijn.

Al spoedig blijkt dan dat Durkheim zich weliswaar uitvoerig uitgesproken heeft over toekomstige ontwikkelingen, maar dat deze uitspraken niet zonder meer bruikbaar zijn als het gaat om de konstruktie van een theoretisch model.

In de laatste hoofdstukken van zijn werk over de verdeling van de arbeid gaat Durkheim's toetsbaar gebleken theorie over in een utopische toekomstvisie.

Daarin voorspelt hij wat de arbeidsverdeling en de normatieve integratie betreft een lineaire ontwikkeling.

De arbeidsverdeling zal zich, tot heil en zegen van allen, doorzetten in een, in principe ongelimiteerde, specialisering en differentiëring van taken en funkties. In en door deze ontwikkeling makt het individu zich in toenemende mate los van de oude, traditionele kaders en wordt het in doen en denken steeds autonomer.

Het kullektieve geweten wordt gereduceerd tot een noodzakelijk minimum aan repressieve sankties, geconcentreerd rond respekt voor de autonomie, de waardigheid en de vrijheid van het individu. 
Door de toenemende funktionele interdependentie wordt het individu zich in toenemende mate bewust van zijn eigen afhankelijkheid van de samenleving, waaraan het op zijn eigen plaats een bijdrage levert.

In deze visie ziet Durkheim de arbeidsverdeling als de bron van sociale cohesie en van sociale solidariteit.

Volgens zijn uitspraken voert de arbeidsverdeling ook tot een nieuwe morele code. Vanuit de noodzaak tot beheersing van de toenemende komplexiteit en funktionele interdependentie ontstaan namelijk professionele codes en een toenemend aantal regels, die de sociale funkties en de rechten en plichten van de individuen op elkaar afstemmen en reguleren. Durkheim benadrukt, dat deze nieuwe morele code, omdat deze niet van boven- en van buitenaf wordt opgelegd en niet berust op geloof en irrationele tradities, maar rationeel is en gebaseerd op sociale solidariteit, het gedrag van individuen zal beheersen en inperken zonder daarmee hun vrijheid van denken en doen wezenlijk aan te tasten.

Hij gaat ervan uit dat de sociale, organische solidariteit en de nieuwe moraliteit het individu ertoe zullen brengen zijn ambities te beteugelen en zich vrijwillig te voegen in een gespecialiseerde, begrensde taak om daarin zijn bijdrage aan de samenleving te leveren.

In verband met de verdere ontwikkeling van het model moet nog worden vermeld, dat aan opvoeding en onderwijs in het geheel der dingen een andere funktie wordt toebedeeld dan in het voorafgaande het geval leek.

Eerder legde Durkheim de nadruk op de verwerving van nieuwe inzichten, van rationele kennis, op persoonlijke ontwikkeling en zelfstandige meningsvorming ( $\$$ 5.1.3). In zijn toekomstvisie krijgen opvoeding en onderwijs tot taak het individu voor te bereiden op zijn latere rol in de samenleving en hem te laten wennen aan de gedachte van omschreven taken en begrensde mogelijkheden.

Van minder belang is hier Durkheim's overtuiging, dat onder de voorwaarden van sociale rechtvaardigheid en van gelijke kansen, arbeidsverdeling en organische solidariteit zullen leiden tot een samenleving waar ieder de plaats inneemt die hij waard is, beloond wordt naar verdienste en elkeen werkt voor het welzijn van allen, of, zoals Giddens (1978) het formuleert van een gedifferentieerde, maar klassenloze en konfliktloze maatschappij. Het gaat er hier niet om uit te zoeken op welke punten en waarom deze redenering wel of niet deugt. Evenmin is de vraag 
aan de orde naar de wenselijkheid of noodzaak van een klassenloze maatschappij, zoals door Durkheim beschreven. Wel van belang zijn hier de konsekwenties, die Durkheim's redenering voor de ontwikkeling van het model zou kunnen hebben. Indien de gedachtengang van Durkheim zou worden gevolgd, dan zou voor het model moeten worden aangenomen dat:

- de arbeidsverdeling zich in principe ongelimiteerd zal doorzetten;

- de verzwakking van de normatieve integratie tot een minimum aan morele consensus zal voortschrijden;

- enerzijds de illegitieme, agressieve gedragswijzen zich op den duur zullen beperken tot vergrijpen tegen de integriteit en waardigheid van de persoon en anderzijds de morele vrijheid van handelen en daarmee de variabiliteit van het gedrag zich in principe nagenoeg onbeperkt zulien uitbreiden;

- het aantal, het werkingsgebied en de omvang van de professionele controle instanties, die de naleving van het groeiend aantal regels ter beheersing van de toenemende komplexiteit moeten bewaken, steeds zulien toenemen;

- steeds meer gedragingen als storend zullen worden ervaren en voor korrektie of behandeling (en registratie) door deze professionele controle instanties in aanmerking zullen komen, waardoor een steeds groeiende proportie van de variabiliteit van het gedrag in principe aan banden zal worden gelegd;

- in feite, vanwege de vrijwillige acceptatie van de nieuwe, rationele, morele code, de als storend ervaren, legitieme gedragswijzen naar verhouding echter steeds minder zullen voorkomen;

- een hoger dan wel meer algemeen geldend opleidingsniveau, vanwege de aanpassingsfunktie van het onderwijs, gepaard zal gaan met lagere frekwenties zowel van illegitieme, alsook van storende legitieme gedragswijzen.

11.2.2 Uitgangspunten en veronderstellingen voor de nadere uitwerking van de theorie

Het zal duidelijk zijn, dat Durkheim's uitspraken voor de verdere ontwikkeling van het model niet alle even bruikbaar zijn. Zijn bijdrage ligt vooral in de paradox die, zoals later nog zal worden toegelicht, in zijn redenering ligt opgesloten. Tegen Durkheim's voorspelling over de ontwikkeling van de arbeidsverdeling kan echter, mits ontdaan van haar visionair, utopische implikaties, weinig worden ingebracht. Het proces van specialisering en differentiëring zet zich in- 
derdaad nog steeds door en leidt in wisselwerking met de technologische ontwikkeling, tot een toenemende komplexiteit van taken, funkties, relaties, of om met Elias (1971) te spreken, tot een steeds dichtere vervlechting van betrekkingen en tot steeds langere, zich over de staatsgrenzen uitstrekkende interdependentieketens. Hierbij behoeft niet alleen aan multinationals, Europese landbouwpolitiek en monetaire slangen te worden gedacht, maar kunnen ook zaken als weersberichten, Interpol of stiptheidsakties van Franse vluchtverkeersleiders ter illustratie dienen.

In verband met de ontwikkeling van het model misschien belangrijker aspekten dan het internationale bereik van het arbeidsverdelingsproces betreffen de voortdurende uitbreiding van het domein van de arbeidsverdeling tot steeds andere sektoren van aktiviteiten, zoals bijvoorbeeld vrijetijdsbesteding, sport, gezondheid, welzijn en de daarmee gepaard gaande beinvloeding en penetratie van de individuele leefwijze en leefsfeer.

In dit opzicht wordt het individu zich inderdaad in toenemende mate bewust van zijn eigen, onontkoombare afhankelijkheid van de samenleving, zij het op andere wijze dan Durkheim waarschijnlijk bedoelde.

Wat betreft de effekten van deze specialiserings- en differentiëringsprocessen op de normatieve integratie lijken Durkheim's uitspraken plausibel, ook al valt te betwijfelen of de morele consensus, het kollektieve geweten zo ver wordt gereduceerd als Durkheim voorziet.

Behalve de integriteit en autonomie van het individu vormt ook de onaantastbaarreid van het eigendom tot op de dag van vandaag een stevig in de repressieve wetgeving verankerde waarde. Daarnaast zijn er ook soms lang latent blijvende bestanddelen van het kallektieve geweten, die indien door bepaalde omstandigheden akuut geworden, een sterk bindende en normatief integrerende kracht blijken te bezitten.

Daarbij valt te denken aan de integriteit van de staat, aan de onaantastbaarheid van het politiekeconomische systeem van de samenleving, kollektieve waarden die ook in geval van bedreiging door slechts kleine groepjes of enkelingen sterke reakties en zware repressieve sankties oproepen. Bovendien kan het kollektieve geweten zich ook uitbreiden, zoals dat bijvoorbeeld ten aanzien van milieubedreigende handelingen lijkt te gebeuren ( $\$ 5.1 .3$ ).

Dit neemt niet weg, dat Durkheim wel eens gelijk zou kunnen hebben met zijn voorspeliing, dat op den duur het gedrag van 
het individu en zijn binding aan de samenleving vooral beheerst en bepaald zullen worden door de morele code, die ontstaat uit de noodzaak tot beheersing van de toenemende komplexiteit van de arbeidsverdeling. In deze, in aantal steeds groeiende, rationele regels, regelingen, voorschriften, procedures, die tesamen in de terminologie van Durkheim de nieuwe marele code vormen, manifesteert de arbeidsverdeling zich waarschijnlijk het duidelijkst voor het individu. Waar het zicht op de eigen bijdrage aan het totale proces en op de eigen positie daarin allang verdwenen is, blijft voor het individu de ervaring van zijn afhankelijkheid van het geheel door middel van de gedragsbeperkende bepalingen waaraan hij is onderworpen.

Het is echter zeer de vraag of deze ervaring van afhankelijkheid en binding aan de samenleving het door Durkheim voorzegde effekt zal hebben, namelijk de organische solidariteit, op grond waarvan het individu zich vrijwillig naar de nieuwe, rationele code zal voegen.

Deze hypothese lijkt nog minder plausibel als wordt bedacht, dat in de feitelijke ontwikkeling de doelstellingen van het onderwijs niet beperkt zijn gebleven tot de aanpassingsfunktie die het in de gedachtengang van Durkheim zou moeten vervulien.

Ondanks regelmatig uitgeoefende aandrang om het onderwijs vooral aan te passen aan de behoeften van het bedrijfsleven en aan de eisen van het toekomstige beroepsleven, is in feite bij de ontwikkeling, inrichting en spreiding van het onderwijs de nadruk in steeds sterkere mate op de algemene vorming, de persoonlijke ontplooiing en de individuele mondigheid als staatsburger komen te liggen -idealen en doelstellingen die sterk doen denken aan de door Durkheim zo positief beschreven gevolgen van een verzwakkende normatieve integratie ( $\$ 5.1 .3$ ).

Hier is sprake van een paradox in Durkheim's voorstelling van zaken. Enerzijds benadrukt hij het autonome individu, die door de ontwikkeling van de arbeidsverdeling is bevrijd van traditionele kaders en irrationele denkpatronen en de vrijheid heeft om beslissingen te nemen en gedragsalternatieven te kiezen. Anderzijds beschrijft hij het individu, dat op grond van zijn funktionele afhankelijkheid en geholpen door op aanpassing gericht onderwijs, zich vrijwillig onderwerpt aan de morele code, die tengevolge van de zich ontwikkelende arbeidsverdeling in toenemende mate zijn bedrags- 
alternatieven beperkt.

Durkheim's beroep op de sociale solidariteit waardoor deze paradox zou kunnen worden opgelost, is weinig overtuigend. Deze twijfel geldt overigens ook ten aanzien van de veel minder ideologische en dichter bij de werkelijkheid staande opvatting van Elias (1939) over de 'Selbstzwang'. Elias stelt namelijk, zeer kort samengevat, dat de dwang die voor de enkeling uit de toenemende vervlechting en differentiëring van maatschappelijke funkties en de groeiende interdependentie voortvloeit om zijn gedrag steeds gedifferentieerder en stabieler te reguleren, langs een impliciet, vaak onbewust en automatisch werkend mechanisme tot verinnerlijkte zelfdwang wordt.

$\mathrm{Nu}$ kan inderdaad niet worden ontkend, dat in het merendeel van de gevallen de meeste mensen, omdat ze het nu eenmaal zo geleerd hebben en het leven toch al ingewikkeld genoeg is, zonder al te veel reflektie op hun handelen, zich voegen naar de regels en hun gevolgen, dus op tijd opstaan om naar het werk te gaan of de kinderen naar school te brengen, rechts houden in het verkeer, kampeerkaarten aanvragen en pasfoto's laten maken, minstens een uur voor vertrek op het vliegveld aanwezig zijn, op gezette tijden de vuilniszakken buiten zetten en de ziekenfondskaart meenemen naar de dokter.

Evenzeer valt echter waar te nemen, dat voor veel mensen de rationaliteit van de regels en voorschriften lang niet altijd voldoende aanleiding is om zich vrijwillig en in solidariteit met de samenleving te schikken. Het is niet altijd voor iedereen gemakkelijk te accepteren een pasgebouwd schuurtje in de eigen tuin te moeten afbreken omdat de bouwvergunning mog niet officieel was afgegeven, zijn salaris niet meer kontant in handen te krijgen, maar een giro- of salarisrekening te moeten nemen, een autogordel te moeten gebruiken of de Kalkarheffing te moeten betalen, terwijl men ernstige bezwaren heeft tegen de bouw van kerncentrales.

In een groot aantal gevallen wordt de dwang, die van de steeds toenemende interdependentie van mensen en funkties uitgaat, ook bewust als zodanig gevoeld. Uiteraard zullen daarbij individuele disposities en situaties een rol spelen. Afgezien van deze individuele faktoren, zijn er echter ook aspekten van de funktionele interdependentie en de beheersing daarvan aan te wijzen, 
waardoor de gedragsbeperkende effekten van het voortschrijdend proces van de arbeidsverdeling niet meer als redelijk en acceptabel worden ervaren.

Rationele regels zijn niet altijd voor iedereen begrijpelijke of billijke regels.

Naarmate de interdependentieketens langer zijn of, zoals Elias (1971) het uitdrukt, het spel op meer niveaus gespeeld wordt, is het moeilijker de rationaliteit van de regels langs de gehele keten en over de verschillende spelniveaus te blijven volgen.

De acceptatie en naleving van een onbegrijpelijke of als willekeurig ervaren morele code worden bemoeilijkt naarmate de werking zich meer vitbreidt naar de individuele leefsfeer. Niet iedereen, die zijn gedragsalternatieven ziet ingeperkt, heeft aan de totstandkoming van die code kunnen bijdragen of heeft zich daarbij betrokken gevoeld. Om opnieuw Elias te citeren, spelers of figuraties van spelers verschilien in speelsterkte en in sterkte van spelpositie. De kansen om het spelverloop te bepalen en de spelregels vast te stellen zijn ongelijk verdeeld. Ongelijkheid in machtspositie, dat wil zeggen ongelijke kansen om de eigen belangen en opvattingen in wetten en bepalingen veilig te stellen, draagt niet bij tot een algemene, vrijwillige acceptatie van de morele code of tot een organische solidariteit, zoals bedoeld door Durkheim ${ }^{1}$ J.

Een ander aspekt van de funktionele interdependentie betreft de toenemende kwetsbaarheid en de daardoor steeds sterkere noodzaak tot beheersing van het komplexe systeem van de arbeidsverdeling.

Een groeiend aantal regels en bepalingen is gericht op de instandhouding en bescherming van het systeem. Door deze ontwikkeling ontstaat er niet alleen een kans op strijdigheid van de morele code met andere opvattingen, belangen en waarden, maar wordt het ook steeds moeilijker de rationaliteit van de code in te zien en te aanvaarden.

Deze en dergelijke, met een toenemende specialisering en differentiëring van funkties samenhangende faktoren leiden er toe dat, anders dan Durkheim voorspelde, de gevolgen van de rationele gedragscode in toenemende mate warden ervaren als moeilijk te accepteren beperkingen van de gedragsalternatieven, als een inbreuk op de eigen, persoonlijke beslissingsvrijheid.

De beleving van de gedragsbeperkende werking van de rationele 
morele code als een van buitenaf opgelegde dwang wordt ongetwijfeld versterkt door een anderzijds steeds grotere persoonlijke beslissingsvrijheid en individuele mondigheid en een toenemende spreiding van rationele kennis tengevolge van een steeds stijgend opleidingsniveau.

De paradox van deze ontwikkeling ligt daarin dat zowel de gedragsbeperkende werking van een zich uitbreidende rationele gedragscode als de gedragsverruimende invloed van een verzwakkende normatieve integratie gevolgen zijn van een steeds toenemende specialisering en differentiëring van funkties. Bij de verdere uitwerking van de theorie zal met deze paradoxale ontwikkeling rekening moeten worden gehouden. Uitgangspunt zou kunnen zijn, dat een steeds toenemende funktionele interdependentie op den duur gepaard zal gaan zowel met een grotere variabiliteit als tezelfdertijd met een groeiende invariabiliteit van het gedrag.

Met dit uitgangspunt wordt gesteld, dat niet alleen een sterke normatieve integratie, maar ook een ver-ontwikkelde funktionele integratie zal leiden tot invariabiliteit van het gedrag. In plaats van een kollektieve consensus over traditionele waarden, voorstellingen en sentimenten, kan ook een rationele morele code, gericht op de beheersing van het funktioneel interdependente systeem de variabiliteit van het gedrag aanzienlijk beperken.

Indien achtereenvolgens zou worden aangenomen dat:

- het proces van arbeidsverdeling zich zal doorzetten, de normatieve integratie verder zal verzwakken en de funktionele interdependentie zal toenemen;

- het opleidingsniveau verder zal stijgen, de individuele mondigheid en de aanspraken op persoonlijke beslissingsvrijheid zullen toenemen;

- de toenemende funktionele interdependentie en de noodzaak tot beheersing daarvan een steeds sterkere beperking van de gedragsalternatieven teweeg zullen brengen;

- de steeds sterkere inperking van de gedragsalternatieven door de rationele gedragscode mede ten gevolge van de zwakkere normatieve integratie en het hogere opleidingsniveau, in toenemende mate als dwang zal worden ervaren; dan zou, op grond van dit uitgangspunt en overeenkomstig de in het model gevolgde redenering, voor te toenemende arbeidsverdeling enerzijds een indirekte, min of meer lineair verlopende relatie met legitieme gedragswijzen kunnen worden verwacht en anderzijds een eventueel direkt, kromlijnig ver- 
band met illegitieme of agressieve gedragswijzen verondersteld kunnen worden.

In de volgende, vooralsnog spekulatieve en globale veronderstellingen, is deze uitspraak wat nader uitgewerkt:

a. Een toenemende arbeidsverdeling zal, via een verzwakking van de normatieve integratie, leiden tot hogere frekwenties van legitieme gedragswijzen.

b. In geval van een aanvankelijk relatief sterke normatieve integratie, zal een toenemende verzwakking van de normatieve integratie leiden tot lagere frekwenties van illegitieme of agressieve gedragswijzen.

Bij een aanvankelijk relatief zwakke normatieve integratie zal dit effekt waarschijnlijk verdwijnen.

c. In geval van een relatief zwakke normatieve integratie en een relatief hoog opleidingsniveau zal een toenemende arbeidsverdeling leiden tot hogere frekwenties van illegitieme of agressieve gedragswijzen.

Indien in een toekomstig onderzoek deze relaties met recente gegevens op gemeenteniveau zouden kunnen worden onderzocht dan zouden op grond van deze veronderstellingen de volgende spekulatieve verwachtingen kunnen worden geformuleerd:

1. Een toenemende economische diversiteit zal gepaard gaan met een lagere normatieve integratie; een zwakkere normatieve integratie zal gepaard gaan met hogere frekwenties van legitiem (vlucht)gedrag.

2. In gemeenten met een relatief hoge normatieve integratie zal een verzwakking van de normatieve integratie gepaard gaan met een daling van de frekwenties van illegitiem of agressief gedrag; in gemeenten met een relatief zwakke normatieve integratie zal een verdere verzwakking van de normatieve integratie niet meer leiden tot lagere frekwenties van illegitiem of agressief gedrag.

3. In gemeenten met een relatief zwakke normatieve integratie en een relatief hoog opleidingsniveau zal een toenemende economische diversiteit gepaard gaan met hogere frekwenties van illegitiem of agressief gedrag.

Zoals gezegd zijn deze hypothesen vooralsnog tamelijk spekulatief.

Een belangrijk nog op te lossen probleem betreft de aard van de illegitieme of agressieve reakties, die verband houden met de beperking van de gedragsalternatieven door de rationele gedragscode ter beheersing van het arbeidsverdelingsproces. 
Het ligt niet voor de hand hierbij uitsluitend te denken aan de eerder gebruikte criminaliteitsvariabelen.

De individuele mondigheid, de rationele kennis en inzichten, die in de gevolgde redenering worden beschouwd als kondities, waaronder de gedragsbeperkende werking van de rationele gedragscode als 'external restraint' wordt ervaren, zouden ook wel eens van invloed kunnen zijn op de aard en de richting van de agressieve reaktie.

Hierbij valt te denken aan de mogelijkheid dat, gebaseerd op inzicht in de oorzaken van de frustratie, de agressiviteit niet irrationeel en toevallig, maar beheerst en gericht wordt geuit (bijvoorbeeld akties, demonstraties, burgerlijke ongehoorzaamheid).

Een andere mogelijkheid is, dat enerzijds het inzicht in de oorzaken van de 'external restraint', doch anderzijds de ongrijpbaarheid daarvan de openlijke uiting van de agressiviteit verhinderen. Dit zou kunnen betekenen, dat ook rekening zou moeten worden gehouden met effekten op andere verschijnselen, zoals bijvoorbeeld de sterfte aan hart- en vaatziekten. Een andere vraag, waaraan nadere aandacht zal moeten worden besteed, betreft de invloed van de omvang ofwel het sociale volume naast of in kombinatie met de kamplexiteit van de arbeidsverdeling. Aangezien in het hier gevoerde betoog aan het sociale volume zowel gedragsverruimende als gedragsbeperkende effekten kunnen worden toegeschreven, is de rol van dit concept in het model nog niet met zekerheid aan te geven. Voordat het model overeenkomstig de gevolgde redenering verder kan worden ontwikkeld en getoetst moet nog een groot aantal van deze en dergelijke vragen en problemen worden beantwoord en opgelost.

Het is niet de bedoeling deze nu verder op te sommen en te bespreken. Hier wordt volstaan met de konklusie dat desondanks de aangegeven richting, waarin het model verder zou kunnen worden ontwikkeld, voldoende perspektief lijkt te bieden voor een toekomstige exploratie, eventueel in kombinatie met één van de hiervoor genoemde toetsingsmogelijkheden. 

NOTEN

Noot bij hoofdstuk $\hat{1}$ :

l) Overigens kan hier worden opgemerkt, dat de analyse van relaties tussen kenmerken en gedragingen van individuen op boven-individueel niveau niet altijd problemen oplevert, maar soms ook problemen kan oplossen.

Zo kunnen op boven-individueel niveau relaties en gedragspatronen worden vastgesteld en gemeten, die door een te grote error-variantie op indivieel niveau niet waarneembaar zijn. Bij wijze van voorbeeld kan worden gedacht aan de vele faktoren die de beslissing beinvloeden om met een gezondheidsklacht naar een dokter te gaan, welke op individueel niveau nauwelijks te ontwarren en te identificeren zijn, maar op praktijkniveau duidelijk herkenbare en meetbare patronen vormen.

Noten bij hoofdstuk 2:

1) Centraal Bureau voor de Statistiek. Typologie van Nederlandse Gemeenten naar Urbanisatiegraad, 31 mei 1960.

2) Centraal Bureau voor de Statistiek: 13e Algemene Volkstelling 31 mei 1960. Deel 2: Bevolking van de gemeenten en onderdelen van de gemeenten.

3) Centraal Bureau voor de Statistiek: 13e Algemene Volkstelling 31 mei 1960. Deel 12: Bevolking in inrichtingen en tehuizen.

4) Het aantal in 1958 t/m 1962 nieuw ingeschreven patienten van de Medische Consultatie Bureaus voor Alcoholisme vormt hierop een uitzondering. Dit gegeven was uiteindelijk voor slechts 149 gemeenten beschikbaar.

5) De variabelen zijn: sterftecijfer, doodgeboortecijfer, zuigelingensterfte, sterfte door kwaadaardige nieuwvormingen, sterfte door hart- en vaatziekten, totaal aantal gemelde gevallen van besmettelijke ziekten, aantal gemelde gevallen van salmonellosen, dysenterie, hepatitis infectiosa en roodvonk.

6) Behalve het slechts voor 149 gemeenten beschikbare promillage patienten van de Medische Consultatie Bureaus werden op grond van hun rekenkundige afhankelijkheid van andere variabelen nog een vijftal variabelen niet bij deze componenten-analyse betrokken, te weten: index jeugdcriminaliteit, onherroepelijke veroordelingen en seponeringen, asyleringscoëfficiënt, besmettelijke ziekten en sterftecijfer. 
Noten bij hoofdstuk 3:

1) In dit verband kan worden gewezen op de interessante poging van Seibel (1972) tot de ontwikkeling van een algemene en empirisch toetsbare theorie. Hij baseert zich daarbij op de premissen dat er in alle bekende samenlevingen sprake is van afwijkend gedrag, van sociale sankties en van sociale integratie en op het axioma, dat deze verschijnselen onderling samenhangen. Hij werkt deze relaties en hun kondities uit in een aantal theorema's, die tesamen een logisch coherent formeel systeem vormen, dat zich in principe in een corresponderend operationeel systeem laat vertalen. .

2) De variabele 'urbanisatiegraad' werd niet bij de componenten-analyse betrokken, omdat een aantal van de gemeentekenmerken waruit de urbanisatiegraadtypologie is opgebouwd (socio-economische struktuur, woon-werkverkeer, morfologische karakteristieken) hier als afzonderlijke variabelen zijn opgenomen.

Noten bij hoofdstuk 4:

l) Deze theorieën vormen overigens ook het uitgangspunt van studies met een etiologische interpretatie van de relatie tussen de mate van sociale integratie en het voorkomen van afwijkend gedrag. Als voorbeeld hiervan kan worden genoemd de statusintegratie theorie, warin een in termen van geringe duurzaamheid en in-stabiliteit van de relaties opgevatte, zwakke sociale integratie wordt beschouwd als oorzaak van zelfmoord(Gibbs en Martin, 1958, 1966) of van chronische ziekten (Dodge en Martin, 1970).

Durkheim zelf is niet eenduidig in zijn opvattingen omtrent het mechanisme van de samenhang. Enerzijds stelt hij met betrekking tot de zelfmoord, dat in geval van een zwakke sociale integratie het normatieve systeem zijn gedragsregulerend vermogen verliest, weshalve de werking van suicidogene faktoren wordt 'ontremd'. Anderzijds meent hij evenwel, dat een zwakke sociale integratie zelf oorzaak is van de zelfmoord, dit op grond van zijn overtuiging dat zonder banden met de gemeenschap het leven zinloos is: 'The individual yield to the slightest shock of circumstances because the state of society has made him a ready prey to suicide'. 
Vervolg noten bij hoofdstuk 4:

Deze opvatting is voor Timasheff (1957) aanleiding Durkheim van een extreme vorm van sociologisch realisme te beschuldigen.

Overigens keert Durkheim in een later hoofdstuk van zijn 'Suicide" weer terug tot de interpretatie vanuit de 'social control' benadering, getuige zijn uitspraak: 'Egoistic suicide results from the fact that society is not sufficiently integrated at all points to keep its members under control'.

2) De auteur merkt daarbij spijtig op, dat 'indien dus de katholieken in Nederland als geheel genomen voor bijna alle delicten boven het gemiddelde uitgaan, dan moet men dit aldus zien, dat Noord en Zuid het als het ware voor elkaar bederven: zonder het Noorden zouden de katholieken voor misdrijven tegen de eigendom een gunstig figuur maken, zonder het Zuiden, zou onze ruwheidscriminaliteit weinig opvallends vertonen'.

3) Met betrekking tot deze veronderstelling vraagt Havermans zich -terecht- af, waarom een algehele morele vervlakking in de stad, die zich uit in bezoek aan publieke vrouwen, overspel e.d., halt zou houden voor strafbare aberraties en waarom, omgekeerd, een mens die zich op grond van godsdienstige overtuiging verre houdt van sexuele wandaden, welke toevallig niet in de strafwet genoemd worden, tot spanningen zou geraken, welke in exhibitionisme, paedophilie e.d. afgereageerd moeten worden.

4) Zoals blijkt bij Kempe (1938) verklaart Bonger de hoge criminaliteit en de lagere zelfmoordfrekwentie onder rooms-katholieken uit het relatief geringe aantal welgestelden in deze bevolkingsgroep ten gevolge van de, door onderdrukking opgelopen economische achterstand.

5) Feber merkt op, dat het aantal niet-praktiserende gevangenen verband houdt met het aantal niet-praktiserenden onder de vrije katholieken uit hetzelfde woongebied. Ter illustratie geeft hij een staatje van percentages non-paschanten per bisdom of dekenaat, waaruit valt of te leiden, dat verreweg de laagste percentages non-paschanten voorkomen in de bisdommen waar de roomskatholieken oververtegenwoordigd zijn wat betreft de 
Vervolg noten bij hoofdstuk 4 :

geweldscriminaliteit (Den Bosch 1.48\%, Breda 1.77\%), terwijl de hoogste percentages non-paschanten voorkomen in de dekenaten (Amsterdam 38.0\%, Den Haag 24.8\% en Rotterdam $35.0 \%$ ) waar de rooms-katholieken ondervertegenwoordigd zijn wat betreft de geweldscriminaliteit, doch oververtegenwoordigd wat betreft de vermogensmisdrijven (gegevens over 1929/1930).

6) Wat betreft de nadelige gevolgen van deze latente funktie van het celibaat ontleent Feber bewijskracht aan zowel het relatief grote aantal, soms zelfs geniaal-, begaafden dat uit domineesfamilies voortkomt, als de grote proportie van de tussen 300 en 600 na Chr. optredende Pausen die als onwettige zoon van een geestelijke het levenslicht zagen.

Feber meent, dat het nadelig effekt van het celibaat gekompenseerd kan worden door een groot kindertal van de overige 'katholieken van goeden aanleg'. Hij is daarom ongerust over de terreinwinst van het toegevende standpunt ten aanzien van de periodieke onthouding -een kontra-selektie zal de cijns zijn, die 'aan de kinderbeperking onder de beter aangelegden' betaald zal moeten worden.

Gezien het overwegend afwijzende standpunt van de kerk ten aanzien van de sterilisatie, kan ook hiervan geen oplossing worden verwacht. Feber waarschuwt dat, indien andere groeperingen wel sterilisatie toestaan, in het katholieke volksdeel een relatief groter aental konstitutioneel minderwaardigen is te verwachten.

7) Kempe (1938) citeert in dit verband Pompe, die zich afvraagt of de geestelijkheid inderdaad per definitie en in alle opzichten een positieve selektie vormt, het celibaat kan ook 'ongunstige' eigenschappen wegselekteren. Het is bovendien de vraag of alle geestelijken anders wel waren getrouwd. Duynstee, eveneens door Kempe geciteerd, betwijfelt of de celibaat-theorie wel in overeenstemming is met de biologische erfelijkheidsleer, bovendien acht hij de roeping een kwestie van milieu en niet van aanleg. 
Vervolg noten bij hoofdstuk 4:

8) Kruyt wijst er op, dat de overigens veel schaarsere sociografische gegevens over de boven-Moerdijkse katholieken indiceren dat een dergelijke beschrijving ook op hen van toepassing is en citeert als voorbeeld Ali van Wijhe-Smeding's beschrijving van de Volendammers als: 'luchthartig, jolig, ongelofelijk ruw van taal en kinderlijk-naief. Als alle goede katholieken nemen zij zeer getrouw hun kerkelijke plichten waar, maar als zij die plichten volbracht hebben, keren zij zich weer breed de wereld toe. Zij zondigen luchthartig. Maar als zij weer bij mijnheer Pastoor te biechten zijn geweest, hebben zij een schone lei -en beginnen opnieuw. Zij zijn 'verslingerd' aan de wereld en aan alle wereldse genoegens. Dolle kermisvierders zijn de Volendammers. Er zit in deze mensen een felle levensdrift. Bijna aanhoudend glanst en flonkert er een lach in hun ogen'.

Wat betreft de calvinisten kan wel worden gekonkludeerd dat hun eeuwenlange strijd 'tegen kermis, toneel, Zondagsvermaken enz. ons volksleven ongetwijfeld heeft vergrauwd'. Toch moet men voorzichtig zijn met generalisaties. 'Vergelijkt men de jolige, luchthartige, kinderlijk-naĩeve goed-katholieke Volendammer met de zwaarmoedige, orthodox-hervormde of gereformeerde Markers, die 'door het leven gaan, als hadden zware zorgen hun levenslust voor een. groot deel gebroken', dan komt de correlatie duidelijk uit. Maar 'de gereformeerde Urker neemt weer, ondanks zijn strenge Schrift-opvattingen, het leven gemoedelijk, is ook altijd goedsmoeds en ziet er veelal glunder en genoeglijk uit!'.

In dit verband zou men onder de indruk kunnen geraken van de hoge score op de faktor agressief gedrag van de gemeente Urk, ware het niet dat de score van de weinig 'jolige' en 'van de wereld afgekeerde' minstens even orthodox-protestantse gemeente Staphorst, hoewel lager dan die van Urk, hoger is dan de agressief gedrag score van de zuidelijk gelegen en voor meer dan $90 \%$ van hun bevolking rooms-katholieke gemeenten Asten, Eersel, Made en Drimmelen, Eysden en Hilvarenbeek. 
Vervolg noten bij hoofdstuk 4 :

9) Als argumenten voert hij aan dat reeds in de $12 \mathrm{e}$ eeuw, voordat er sprake was van enig protestantisme, in de rooms-katholieke Italiaanse steden het kapitalisme welig tierde, dat Luther en ook Calvijn eerder anti-kapitalistisch gezind waren en dat ook nu rooms-katholieken op het gebied van industrie, bankwezen en handel met succes hun ondernemingszin doen blijken -zoals van Weringh (1968) opmerkt 'kan men C \& A geen lapjeskoopman noemen of $V \& D$ rangschikken onder de kleine kruideniers, die met moeite het hoofd boven water houden'.

10) In dit verband kan men zich afvragen of deze, door van Rooy als 'pijnlijk' omschreven achterstelling en maatschappelijke 'apartheid' de voedingsbodem vormt van de hier nog niet eerder vermelde 'marechaussee-theorie', waarin de hogere criminaliteitscijfers van de roomskatholieken worden verklaard uit de grotere opsporingsintensiviteit van de overwegend uit 'noorderlingen' bestaande Koninklijke Marechaussee in de zuidelijke, katholieke provincies. Deze theorie, die niet door feiten wordt gestaafd en zoals Kempe (1938) opmerkt geen verklaring biedt voor het door Feber gekonstateerde feit, dat de economische criminaliteit van de rooms-katholieken in de niet-katholieke grote steden boven de grote rivieren hoger is dan in het katholieke zuiden, heeft weinig bijgedragen tot de oplossing van het probleem. maar lijkt wel indikatief voor de mentaliteit van een verdrukte, of zich verdrukt voelende, minderheid.

11) Deze opvatting stemt overeen met Kempe's konklusie, dat niet zozeer de strakke leiding van de rooms-katholieke geestelijkheid op zich, maar vooral het wegvalien van deze leiding een criminogene faktor kan zijn.

12) Van Rooy is het dan ook eens met de opmerking van van den Dries (Vereeniging, 1941) dat warschijnlijk ook het voor de katholiek zo belangrijke verschil tussen dagelijkse zonden en doodzonden een criminogeen effekt kan hebben. De niet-katholiek kent 'deze scherpe scheidslijn niet. Indien hij de zwaarte van verschillende feiten vergelijkt, gaapt er voor hem geen afgrond tussen een feit dat naar katholieke opvatting een zeer ernstige dagelijke zonde is en een feit dat naar katho- 


\section{Vervolg noten bij hoofdstuk 4:}

lieke opvatting de minst ernstige doodzonde vormt. Zodra daarentegen een katholiek hoort, dat een vergrijp slechts een dagelijkse zonde is, kan bij hem de neiging ontstaan dien misslag min of meer gelijk te stellen met verzuimen ten aanzien waarvan geschreven staat, dat de grootste heilige hen meermalen daags begaat'.

13) In dit verband interpreteert hij het door Kempe (1938) gesignaleerde verschil tussen de eerder begonnen en zich grotendeels buiten de kerkelijke instanties en geestelijkheid om afspelende protestantse matschappelijke organisatie en de pas later op gang komende, zich in kerkelijk verband onder leiding van de geestelijkheid voltrekkende, katholieke sociale beweging, niet zo zeer als een criminogene faktor, maar veeleer, evenals de criminaliteit, als een gevolg van de morele opvattingen en van de gereserveerde houding jegens de maatschappelijke ontwikkelingen, die de rooms-katholieken zich op grond daarvan gedwongen voelen aan te nemen.

14) Over de periode 1959/60 vertoonden de rooms-katholieken ook landelijk nog steeds het hoogste criminaliteitscijfer, zoals blijkt uit de door Weringh (1968) vermelde C.B.S.-gegevens - totaal aantal misdrijven ingevolge het Wetboek van Strafrecht per 100.000 inwoners van 10 - 79 jaar: rooms-katholiek : 936 geen kerkgenootschap : 835 nederlands-hervormd : 688 overige kerkgenootschappen: 483 gereformeerd : 424 (totale bevolking : 786)

Anderzijds geeft onderstaande advertentie van het RoomsKatholiek Centrum Pro Fide et Ecclesia, uit de Volkskrant van 16 mei 1974 een sprekend voorbeeld van het 'hoge goed' van een 'onverslapte band tussen godsdienstig en sociaal leven'.

\section{ALARM}

OLDERS, op vele scholen houdt men zich druk bezig met de seksuele voorlichting van uw kinderen. Uw kinderen worden daar niet voorgelicht maar VOORGELOGEN.

$U$ als ouders bent de eerste en voornaamste OPVOEDERS. 
Vervolg noten bij hoofdstuk 4:

$U$ hebt het RECHT en de ZWARE PLICHT uw kinderen zelf op te voeden.

Als goede en verstandige ouders stelt $u$ uw kinderen niet nodeloos aan gevaar bloot. Door de sex-voorlichting lopen zij echter zeer groot gevaar, hun ziel wordt namelijk gedood, omdat zij worden aangezet tot ZEDELOOSHEID, dus tot een (DOOD)-zondig leven.

$U$ hebt dan ook het RECHT, ja zelfs de PLICHT, tegenover GOD en omwille van het aards en hemels geluk van uw kinderen, hen te onttrekken aan de sex-lessen. Geen enkele school kan $u$ of uw kinderen dwingen aan de sex-lessen deel te nemen.

OUDERS: Kent UW VERANTWOORDELIJKHEID; Weest $u$ zich bewust van uw RECHTEN; Kent uW PLICHT t.o.v. uw kinderen.

Laat uw kinderen niet deelnemen aan de sex-lessen, ook niet aan die van de school-televisie.

HOUDT UW KINDEREN UIT DIE LESSEN WEG:

15) Evenals Henry en Short gaan whitt et al. er vanuit, dat de mate van 'external restraint' bepalend is voor de richting, waarin het individu geneigd is de schuld voor zijn frustratie te zoeken -bij zichzelf of bij anderenen daarmee voor de richting van zijn agressie -zelfmoord of moord. Zij veronderstellen dan, dat protestanten met hun benadrukking van de individuele verantwoordelijkheid jegens God in geval van frustratie meer geneigd zullen zijn de schuld daarvoor bij zichzelf te zoeken, wat hen predisponeert tot zelfmoord, terwijl de rooms-katholieken, die de regels voor hun gedrag ontlenen aan de kollektieve moraal van hun kerk in geval van frustratie veel meer geneigd zullen zijn de schuld daarvan buiten zichzelf te zoeken en hun agressie op anderen te richten.

16) In dit verband kan worden gewezen op Durkheim's konstatering, dat -als een weerspiegeling van de verzwakking van de 'collective conscience' ten gevolge van de toenemende arbeidsverdeling en daarmee gepaard gaande spe- 
Vervolg noten bij hoofdstuk 4:

cificering en individualisering van de menselijke relaties- steeds meer levenssferen aan het bereik van het Strafrecht zijn onttrokken, dit echter met éen uitzondering. De strafwetgeving ('repressive law') heeft namelijk een uitbreiding ondergaan wat betreft de bescherming van de persoon. Hij ziet dit als een indikatie voor de verschuiving van het kollektief naar het individu als de centrale waarde in de samenleving.

Noten bij hoofdstuk 5:

1) Vergelijk de uitspraken van van Rooy ( $\$$ 4.4.1) over ontucht, prostitutie, zelfmoord, geboortebeperking als 'heel wat ernstiger dan menig kwaad dat de wet als misdrijf of overtreding kwalificeert', alsook de advertentie (noot 4.14), waarin over de seksuele voorlichting op scholen in termen van doodzonde wordt gesproken.

2) Dit proces is nog steeds aan de gang, getuige bijvoorbeeld het verdwijnen van de opkamstplicht bij verkiezingen, het schrappen van artikel 248 bis van het wetboek van Strafrecht betreffende homoseksuele handelingen tussen meerderjarigen, de 'baas in eigen buik' akties, de diskussie rond de wijziging van artikel 251 bis Wetboek van Strafrecht en de legalisering van de sociaal-geindiceèrde abortus provocatus (zie bijvoorbeeld jaargang 25 (1970) van Medisch Contact), de voorstellen tot het vrijgeven van pornografie (Rike, 1972) en tot het doen verdwijnen van een afzonderlijke 'zedelijkheids'wetgeving - de artikelen 240 en 240 bis, 242 t/m 250 en 451 en 451 bis Wetboek van Strafrecht (Werkgroep Nationaal Centrum Geestelijke Volksgezondheid, 1972), de diskussie over de wijziging van de ministeriële beschikking ingevolge artikel 3 van de opiumwet inzake het gebruik van de zgn.'softdrugs', de veranderende opvattingen over de vrijwillige euthanasie, waarbij de nadruk komt te liggen op de 'mondigheid van de sterveling' (Ekelmans, 1971 j en vragen rijzen over een eventuele wijziging van de artikelen 293 en 294 van het Wetboek van Strafrecht -alle kwesties waarin de verschuiving van het 
Vervolg noten bij hoofdstuk 5:

kollektieve geweten naar het individuele geweten konkreet tot uiting komt.

3) Dok deze tendens zet zich door, zoals bijvoorbeeld blijkt lit het in voorbereiding zijnde wetsvoorstel inzake de bescherming van de 'privacy', alsook uit de diskussie rond het probleem van registratie, databanken, volkstelling, koppeling van computerbestanden, warin de noodzaak tot wettelijke matregelen ter bescherming van het individu tegen misbruik van gegevens wordt benadruk. (Nederlandse Staatscourant, 1975).

4) Dit komt ondermeer tot uiting in de strafmaat, zoals bijvoorbeeld in het vonnis van het zgn. 'Leeuwarder Euthanasie Proces' (21 februari 1973), waar de opgelegde gevangenisstraf van één week voorwaardelijk met een proeftijd van een jaar in vergelijking met de maximaal te vorderen gevangenisstraf van 12 jaar, als symbolisch te beschouwen is, alsook in een terughoudend vervolgingsbeleid van het Openbaar Ministerie inzake bijvoorbeeld de pornografie en de abortus provocatus. De individuele en georganiseerde reakties (bijvoorbeeld van het Nederlands Artsen Verbond en de Stichting voor het Ongeboren Kind) op het uitblijven van sankties, zijn overigens indikatief voor een ongelijkmatig verloop van dit proces -een door Durkheim onbesproken gelaten aspekt van de zaak. De diskrepanties in normatieve oriëntatie -kollektief versus individueel geweten- lijken veeleer tot wederzijdse intolerantie dan tot sociale solidariteit te leiden en kunnen, als bron van konflikten, aanleiding geven tot veelal agressief afwijkend gedrag: de Damrellen, het 'schoonvegen' van het Amsterdams Centraal Station, het ingooien van ruiten van sex-shops, het gewelddadig optreden tegen nudisten e.d..

5) Met de huidige milieuproblematiek lijkt opnieuw een uitbreiding van het kollektieve geweten te zijn gegeven. Verschijnselen als aktiegroepen, protestdemonstraties, geëngageerde berichtgeving, burgerlijke ongehoorzaamheid inzake bijvoorbeeld de Kalkarheffing, milieuhoofdstukken in partijprogramma's, termen als 'milieubewustzijn', diskussie over de strafbaarstelling van milieuvervuilende en -bedreigende handelingen e.d. zijn indikatief voor 
Vervolg noten bij hoofdstukken 5:

het ontstaan van een kollektief geweten, waardoor op den duur handelingen, die voorheen behoorden tot het domein van het individuele geweten (aanleg van wegen, landingsbanen, vestiging van fabrieken, lozing en opslag van afvalstoffen, gebruik van insecticiden etc.) worden tot 'acts that offend strong and defined states of the collective conscience' en daarmee tot een nieuw type criminaliteit, namelijk die van milieumisdrijven.

6) Vergelijk bijvoorbeeld de eerder geciteerde uitspraak van van Rooy ( $\$ 4.4 .1$ ), waarin hij stelt, dat een katholiek die zich in een moeilijke situatie gesteld ziet voor de keuze van een niet-strafbare, maar meer immorele en een wel strafbare minder immorele uitweg, eerder nog de 'criminele weg' zal kiezen.

Noten bij hoofdstuk 7:

l) C.B.S. 13e Algemene Volkstelling, 31 mei 1960. Deel $10 B$. Tabel 3, kolommen 2 tot en met 15. In deze tabel worden onderscheiden: bedrijfshoofden in de landbouw, nijverheid en middenstand, vrije beroepen, hogere employé's met een inkomen >f>.500,--, employé's met in een inkomen <f7.500,-landarbeiders, arbeiders met een inkomen $>f 3.750,--$ en arbeiders met een inkomen <f3.750,--.

2) In 1960 werden acht bedrijfstakken onderscheiden: Iandbouw, delfstoffen, industrie en ambacht, bouwnijverheid, openbare nutsbedrijven, handels-, bank- en verzekeringswezen, vervoer-, opslag- en kommunikatie bedrijven en dienstverlening. Bij maximale diversiteit -in elk van de bedrijfstakken is een even grote proportie van de beroepsbevalking werkzaam- wordt de laagste waarde van deze variabele $8(1.00 / 8)^{2}=.125$.

3) De hoogst mogelijke waarde van deze variabele -hoge mate van eenzijdigheid van de economische struktuur- is gelijk 100: de vijf belangrijkste bedrijfsklassen omvatten de totale beroepsbevolking van de gemeente. De laagst mogelijke waarde wordt bepaald door het aantal onderscheiden bedrijfsklassen, zestig in 1960. Aangezien bij maximale diversiteit voor elke bedrijfsklasse het percentage daarin werkzame personen even hoog is $(100 \%: 60=1.67 \%)$ kan 
Vervolg noten bij hoofdstuk 7:

deze variabele, althans voor 1960 geen lagere waarde dan $5 \times 1.67=8.35$ aannemen.

Noot bij hoofdstuk 11:

l) Giddens (1978) wijst er op, dat Durkheim weinig oog heeft voor belangentegenstellingen in de samenleving. Wanneer hij spreekt over belangen dan doet hij dat in de kontekst van de 'push-and-pull of egoism vs. altruism': de belangen van het individu die in konflikt zijn met die van de kollektiviteit als geheel. De notie dat de samenleving ook kan worden gezien als een systeem van dominerende en ondergeschikte belangengroepen, die in een chronische onderlinge spanning verkeren, is Durkheim vreemd. 
SUMMARY

This book reports the results of an investigation into the causes of differential rates of deviant behaviour in 176 Dutch municipalities ranging from 5.000 to 200.000 inhabitants.

A large number of data was collected, including rates of various types of deviant behaviour and measures of sociocultural, economic, physical and demographic characteristics of the 176 municipalities. Most data were obtained from the Netherlands Central Bureau of Statistics for the period 1958 - 1962, the 1960 census being the latest for which data were available.

The study consists of two parts. The first part concentrates on an empirical analysis of the relation between various rates of deviant behaviour and measures of municipal characteristics. In the second part an effort is made to construct and test a theoretical model, in which concepts and propositions found in Durkheim's 'Suicide' and 'The Division of Labor in Society' are combined and modified to explain the differential distribution of deviant behaviour.

Chapter 1 deals with the choice of the unit of analysis. Attention is paid to the problem of 'the ecological fallacy'. Deviant behaviour is operationally defined as offences against institutionalized norms, generaliy considered to be serious enough to justify their treatment, correction and registration.

Chapter 2 gives a description of the variables selected as indices of the various forms of deviant behaviour. Reliability and validity of the variables are discussed and in this connection the concept 'rates producing institutions' is introduced. In order to test the validity of the behavioral variables, their relations with indices of the size and scope of municipal 'rates producing institutions' are investigated. Intercorrelations among the behavioral variables are analyzed by means of the technique of factor analysis. The three common factors that could be extracted were interpreted as 'Flight', 'Agression' and 'Vulnerability'.

Chapter 3 reviews relevant studies referring to causes of deviance and its differential distribution. The selection of indices of the various municipal characteristics is described and again the intercorrelations among the variables are investigated by means of factor analysis. Six common factors 
could be extracted. They were interpreted as 'Welfare urbanism', 'Stagnant growth - ageing', 'Religion', 'Educational facilities', 'Urbanism - deprivation' and 'Industry'. Correlations of these factors with the behavioral factors were analyzed.

Chapter 4 presents the basic ideas and concepts of the theoretical model. Its essential presupposition states, that differences in rates and types of deviant behaviour between communities can be seen as the effects of specific qualities of the social control system of the communities.

Chapter 5 gives a further elaboration of the conceptual model. Induced by an earlier attempt by webb, the presupposition of the model is worked out in terms of Durkheim's propositions concerning the consequences of an increasing division of labour for the integrative basis of the community. Key concepts are normative integration, functional interdependence and variability of behaviour.

In chapter 6 the conceptual model is summarized in fourteen propositions. The most important ones are propositions 8 and 13, respectively: 'An increasing division of labour leads to a weakening of the normative integration of the community'; and, 'The weakening of the normative integration is correlated with an increasing variability of behaviour in the community'.

In chapter 7 the conceptual model is translated into an operational model which can be empirically tested. A description is given of the selection of the variables used as correlates of the theoretical concepts. The factor 'Flight', the divorce rate and the suicide rate are chosen as indices for a relatively great variability of behaviour; the factor 'Aggression', the property crime rate and the personal, violent crime rate are selected as indices for the expected consequences of a relatively great invariability of behaviour. These behavioral variables are regarded as the dependent variables of the model.

Chapters 8 and 9 report the testing of the operational model. The hypotheses concerning the interrelations among the independent variables are tested by using the technique of the partial correlation-coefficient (of the fourth order). To test the effects of the independent variables on the dependent variables a multiple regression analysis is used. 
Chapter 10 discusses the results of the testing and their significance for the conceptual model. Though not all propositions are confirmed, the theory proves to be succesful in predicting the differential distribution of different types of deviant behaviour. The main conclusions are:

- an increasing level of education, a high frequency of social interaction and a growing socioeconomic diversification (division of labour) lead to a weakening of the normative integration of the community;

- the greater variability of behaviour in less normative integrated communities is reflected in higher scores of the factor 'Flight' and in higher divorce and suicide rates; the factor 'Aggression' and the crime rates score relatively low;

- the greater invariability in communities with a relatively strong normative integration results in higher scores of the factor 'Aggression' and in higher crime rates; the factor 'Flight', the divorce and suicide rates score relatively low in these communities;

- the division of labour has no direct relevance for the differential distribution of these types of deviant behaviour.

Chapter 11, finally, presents suggestions for further testing of the theory and discusses the possibility of an elaboration of the theory by considering the consequences of a growing functional interdependence. It is suggested that further weakening of the normative integration and an increasing functional interdependence might lead to a loss of social autonomy of the individual, a growing moral constraint, thus to a greater invariability of behavior. Increasing incidence of aggression and unlawful behaviour might be the result. 

LiJST VAI GHERZCEKSGEMEENTEN, IMGEDEELD NAAR URBANISATIE-CATEGCAJE, MET VERMELDING VAN DE PROVINCIE.

A. PlittelANDSGEMEENTEN

Al Ełoskoop

- s-Gravenzaride

Grootabroek

Loren

Markelo

Stapnorst

Zuidwolte

$\mathrm{A}_{2}$ Ambt Delden

Eellen

Dalisen

Heerhugowaard

Holten

de Lier

Ornmen

Ruurlo

Urk

Zelnem

7.undert

$n_{3}$ Ëorculo

Dubeeldam

DuIven

Elvergen

Henge lo

H11 legom

Hilvarenteek

Clst

Pijnsbure

Smilde

Strijen

Tubbergen

vorden

Weerselo

Withe

$\hat{A}_{4}$ Asten

Denehamp

Eelote

Heesch

riussen

klundert

Langedi jir

Lumster land

Máasarlel

Sossentieim

Virikeveen en

Waverveen

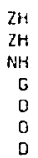

ZH

$\mathrm{NH}$

0

0

d. VERSTEOELI.M.JE

PA AT TEL RIUDSGEHEETTEH

ij 1 Berpeyk

IIf litin

tinxpey io

tereci

515100

i. jetden

is-titosutacted

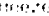

!moingts

$\because, \ldots, \cdots, \cdots, \ldots, t$.

ancuse probrale

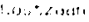

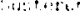

isilntiats.

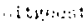

O2 Assendelft

Axel

Eorne

Eoxtel

Breukelen

Eunschoten

Efjeelshoven

Golrle

Goor

Mardinxueld-

Giesendar

Hendrik Ido Ambacht $\mathrm{ZH}$

Koog a.d. Zaan

Krimpen a d IJssel ZH

Kromente

Maarssen

Made en Drimelen NB

Neede

C1sterwijk

Dude Pekela

Rijssen

Schl Jndel

Sliedrecnt

Valkenswaerd

Veghel

Waddinxveen

wormerveer

53 Baarn

Bergen

Blaricum

Gussum

Diemen

Urlebergen-

R1jsenvure

Heemskerk

Heemstede

Hear

L and smeer

Laren

Leiderdorp

Naarden

Oost- on west-sout ith

Son en Breugel

Spljkenlsse

Veldhoven

voorbure

salatre

zandvoort

zoetermeer

H.

?

U

L

0

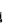

H

H

U⿻

NB

C. SIEUELIJPE GEMEGMEN

C1 Aipingedari

Eolswarc

ronsorifen

Lupre tet st, nyeates ?:

Loestual:

Unkturt

Gorlcermen is, n

G:oenl:

that 1 ort

ludet

I.nctir re:

Hitaneitartit:

reat bet trenland

forticiortei

"jot:ryon

jolnombonet
Vianen

IJsselsteit

2altbome?

zerthze

$\mathrm{C}_{2}$

Alphen a.d. Rif jn

Assen

Brunssum

Culentorg

Delfzigl

Entrivizen

Goes

Gorinchen

Harderwijk

Harlingen

Hoorn

kampen

Masslu1s

Meppel

Middeleurg.

Cldenzad

Oss.

Sittard

Sneek.

Steenvidy

Veenendad

vlissingen

Haalwijk

wageningen

beesp

Winschoter.

zutphen

awijndrecht

$\mathrm{C}_{3}$ Aikmaar

filme to

Gejeen

Gouda

Helmond

Roermanc:

ratandarn

C. Delf

Deventer

Corureche

thengelo

's-Hertagentosch

lifiversum

Legutarcten

Leiven

vidardingen

inolle

is irmom

foredit

creand inger

ratr?

ZH
U
G

2!: 
Bijloge II - 1

\section{LIJST VAN VARIABELEN}

Standanrdisering van de in absolute antallen verzemelde gegevens tot verhoudingscijfers, met vermelaing van de bron wearaan de gegevens $21 \mathrm{jn}$ ontleend.

In de gevalien, woorin de gogevens zljn betrokken op het oantol Inwoners van de gemeente, is oongenomen fat net Inwonertal op 31 mel 1960 - het middelste jaor von de perlode woorop het oncerzook betrokk1ng haeft (1958 $t / m$ 1962) - ols het gemlddelde Inwonertal over deze perlode ken wordon beschouwd. Dit gegeven is ontloend aen de C.B.S. - publicatie 13e Algemene Volkstelling 31 mel 1960. Deel 2: Bevolking van de gemeenten en onderdelen van de geriegnten. De Hoon. 2elst. 1964. Waer de noemer wordt govormd door gubgroepen ult de $8 \mathrm{~B}^{-}$ meantebevolking zijn de gegevens ont leand an de C.B.S. Bolichtorukte tabel no. 3: Bevolking noor burger11 jke staot. geslocht on loeft1jd, 13e Algemeno volkstolling 31 mel 1960 .

Jenzlg anders is vermeld. zijn de variabelen, gescoord van laogste noor hoogste waorde.

VARIABELEN AFWIJKEND EN ZIEKTEGEDRAG

\section{Nlet ultgobrochte stemen}

Gomiddeld aontal nlet uitgebrachte stemen bij de Ciemeenteraads- en Tweede Komerverkiezingen In 1958. 1959. 1952 on 1963 per 100 van het gemlddold oantal kiezers in 1958, 1959, 1962 on 1963.

\section{Ongeldige en blanco stermen}

Gemiddela aantal ongelalge on blanco stemen bij de Gemeenteraads- en Tweede Kamerverklezingen in 1958. 1959. 1962 on 1963 per 100 von het gomlddeld oantal u1tgebrachte stamen in 1958. 1959, 1962 on 1963.

Bron 1 en 2: C.B.S. - publicatios: Stotistiek der Verkiezingen.

1958 - Gemeenteraden, 28 mel. De Hean. Zelst. 1958

1959 - Twoede Kaner der Staten-Generaol, 12 maort. Do koan, Zolst. 1959

1962 - Gemeenteraden. 30 mel. De Haan. Ze1st. 1963

1963 - Twoode Kamer dor Staten-Generaal. 15 me1. De Haan. Zalst. 1963

3. Migrat 1ecijfor

Comiddeld osntal ult de gemeente met binnenlandse bosteming vertrokken personen $1 \mathrm{n} 1958 \mathrm{t} / \mathrm{m} 1962$ per 1.000 inwoners os 31 mel 1960 .

4. Emigrat1ecijfor

Comiduald antal ult de gomeente met buitenlandse bestamming vertrakken personen in $1958 \mathrm{t} / \mathrm{m} 1962$ per 1.000 Inwoners op $31 \mathrm{mel} 1960$.

Bron 3.en.4: C.B.S. gollchedrukte tabollen afo. Bevolkingsstat 1 stioken: gegevans per gemeente betreffende de loop der bevolking in 1958, 1959, 1960. 1361 en 1962

5. Eehtschoidingscijfors

Gomiddold oontol in $1958 \mathrm{t} / \mathrm{m} 1962$ bif de turgerlijke Stand geregistreerde echtschelaingen pe: 1.000 gohuwde vrouwen of 31 me1 1960.

6. Scheldingen van tofol on bed

Cemiddula oontal in $1958 \mathrm{t} / \mathrm{m} 1962$ blJ de Burgerlljho Stand geregistreerde scheidungen van tafel en ved Der 1.000 gehuwde urouwen of $39 \mathrm{mal} 1960$.

Bron.5.en.6: Echescheidingen en scheidingen van tafel en bed van 1958 t/m 1962: tellingen von de ofd. Bevolkingsstatistioken van het C.B.S.

7. Jeupucriminaliteitscijfer

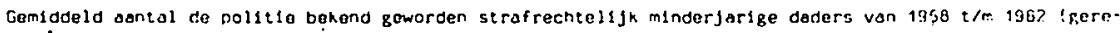

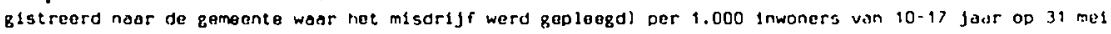
1960.

8. Index jougdcriminoliteit

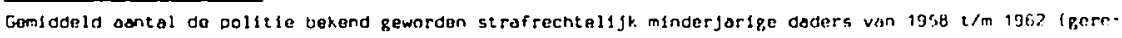

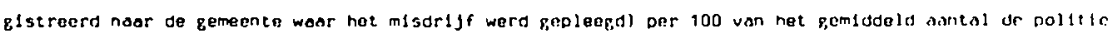

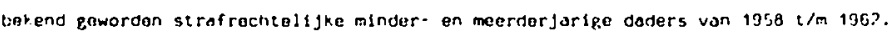

3. Onnerrocpelijhb veroordelingen en soponoringen

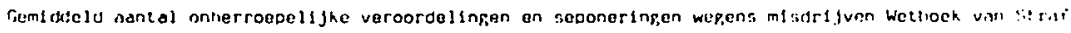

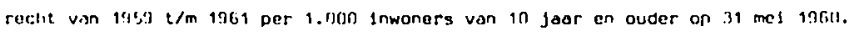


10. Vermogensmisurijuen

Gemiddeld aental onherroepelljke veroordelingen en seponeringen wegens vermogensmisdrijven wetboek van Strefracht van $1959 \mathrm{t} / \mathrm{m} 1961$ per 1.000 Inwoners van 10 jear en outer op 31 mei 1960.

11. Agressieve misorijven

Gemlddeld eantal onherroepel1jke veroordelingen en seponerlingen wegens egressieve misdrijuen Wetboek van Strofrecht van $1959 \mathrm{t} / \mathrm{m} 1961$ per 1.000 Inwoners van 10 jaar en ouder op 31 mei 1960.

12. Sexuele misdrijuan

Gemiddeld aatel onherroepel1jke veroordelingen en seponeringen wegens sexuele misdrijven Watboek van Strafrecht van $1959 \mathrm{t} / \mathrm{m} 1961$ per 1.000 inwoners van 10 jear en ouder op 31 me1 1960.

13. Index egressieve misorijuen

Gemiddeld aantal onherroepelijke veroordelingen en seponeringen wegens agressleve misdrijuen Wetboek van Strofrecht van $1959 \mathrm{t} / \mathrm{m} 1961$ per 100 van het gemiddeld eantel onherroepel1jke veroordelingen en seponeringen wegens misdrijven Wetboek van strafrecht (totaal) van $1959 \mathrm{t} / \mathrm{m} 1961$.

Ergn_?_t/m_13: De pol1tle bekend geworden strafrechtelijk minder- en meerderjarige daders van 1958 $t / m 1962$ naar de gemeente war het misdriff werd gepleggd, het aentel onherroepeligke veroordelingen en seponaringen wegens misdrifven Wetboak van Strafrecht, totas en gesplitst noer vermogens", agressieve en sexuele misdrijuen van $1959 \mathrm{t} / \mathrm{m} 1961$, naar de gemeente van herkomst van de dader - tellingen, afd. Gerechtelijke Statistlek van hat C.B.S.

14. Zolfmoordc1 Ifer

Gemiddeld asntal op grond van justitieal onderzoek tot zelfmoord verklaarde gevallen ven niet-natuur11jke dood van $1958 \mathrm{t} / \mathrm{m} 1962$ per 10.000 inwoners per 31 mel 1960.

Bron 14: Zelfmoorden naer de gemeente van herkomst van de dader van $1958 \mathrm{t} / \mathrm{m} 1962$ - tellingen van de efo. Gerechtelijke Statistiek van het C.B.S.

15. Alcoholische patienten Medische Consultatie Bureaus

Voor 106 gemeenten: gemiddeld aental in $1958 \mathrm{t} / \mathrm{m} 1962$ b1j Medische Consultatie Bureaus voor Alcohalisme nleuw Ingegchreven patienten per 10.000 inwoners van 18 faor en ouder op 31 mel 1960.

Voor 43 gameenten: gemiddeld totaal aantal in $1958 \mathrm{t} / \mathrm{m} 1962 \mathrm{~b} 1 \mathrm{j}$ Medische Consultatie Bureaus voor Alconolisme ingeschreven patienten. gedeeld door de gemiddelde behandelingsduur van het Bureau, per 10.000 Inwoners van 18 jaar en ouder op 31 mei 1960.

Voor 27 gemeenten: geen opgove entvangen.

Bron 15: Aantal in $1958 \mathrm{t} / \mathrm{m} 1962$ nleuw Ingeschreven patienten of totasl aantal in $1958 \mathrm{t} / \mathrm{m} 1962$ ingeschreven patienten - apgave van 17 Medische Consultatie Bureaus voor Alcoholisme

16. Asyleringscoëfficiënt psychiatrische inrichtingen

Gemiddelo oontal in 1967 en 1968 in psychiatrische inrichtingen met een klinisch centrum opgenomen patlenten per 10.000 inwoners op 1 januar1 1968.

17. Schizofrenie

Gemiddeld aantal in 1967 en 1968 met de diagnose schizofrenie (code 295) in psychiatrische inrichtingen met een klinisch centrum opgenomen patienten per 10.000 inwoners per 1 januari 1968.

18. Affectleve psychosen

Gemiddeld aantal in 1967 en 1968 met de diognose affectieve psychose (code 296) in psychiatrische inrichtingen met een klinisch centrum opgenomen patienten per 10.000 inwoners op 1 januari 1968 .

19. Neurosen

Gemiddeld aantal in 1967 en 1968 met de diagnose neurose (code 300) in psychiatrische inrichtingen met een $k l i n 1 s c h$ centrum opgenomen patienten per 10.000 inwoners op 1 Januari 1968.

Bron 16 $t / m$ 19: Aantal in 1967 en 1968 in psychiatrische inrichtingen met een klinisch centrum opgenomen patienten. totoal en gesplitst naar de diagnosen schizofrenie, affectleve psychosen en neurasen - opgave van de Geneeskundige Inspectle van de Geestelijke volksgezondhelJ. gebaseerd op de in samenwerking met de Sectie Psychiatrische Instituten van de Stichting. Nationale 71ekenhulsraad gevaerde "patientenregistratie psychiatrische inrichtinfen". Deze aantallen zijn betrokken op het antal inwoners van de gemeente op 1 januari 1968 C. B.S. - publicatie Bevolking der gemeenter' van Nederland op 1 Januari 1958. Stadsultgeverij. 's-t,ravenhage, 1368 
Bijloge II - 3

20. Afgekeurden Militoirs Disngt met een 55

Gemiddeld aantal in $1959 \mathrm{t} / \mathrm{m} 1961$ ofgekeurde dienstplichtigen met S5-beoorduling per 100 van het gemiddeld aantol in $1959 \mathrm{t} / \mathrm{m} 1961$ gekeurde dienstplichtigen.

21. Afgekeurde Militaira ofienst

Gemiddeld aantal in $1959 \mathrm{t} / \mathrm{m} 1961$ afgekeurde dienstplichtigen per 100 van het gemiddeld aantal in 1959 $t / m 1961$ gekeurde dienstplichtigen.

Bron_20_en_21: Aantal in $1959 \mathrm{t} / \mathrm{m} 1961$ afgekeurde dlenstplichtigen, totaal en met een S5 - door elgen medewerker verzameld uit de keuringsgegevens van de Inspectie van de Militols Geneeskundige Dienst sectio Geneeskundige Aangelegenheden.

Aantel in $1959 \mathrm{t} / \mathrm{m} 1961$ gekeurde - ingeschrevenen voor de dienstplicht en dienstplicht1gan - opgova van de Inspectio.

22. Opname-coëfficiënt algemene ziekenhuizen

Gemlddelde van de opname-coëfficlënten van $1958 \mathrm{t} / \mathrm{m} 1962$.

Bron 22: Gverzicht van de gegevens der z1ekenhuizen in Nederland over het josr 1958 en 1959, 1960, 1961 en 1962. Geneeskundige hoofdinspectie van de volksgezondheid. (In deze pub11caties is als de opname-cab̈flelönt het percentage inwoners van een gemeente dat in de loop van een jaar in een ziekenhuss ward opgenomen vermeld)

23. Besmettel1jke zlakten

Gemiddeld aentel in $1958 \mathrm{t} / \mathrm{m} 1962$ opgegeven gevallen van besmettel1jke ziekten per 10.000 Inwoners op $31 \mathrm{mel} 1960$.

24. Andere solmonellosen

Gemlddeld aantal in $1958 \mathrm{t} / \mathrm{m} 1962$ opgegeven gevallen van andere salmonellosen per 10.000 inwoners op 31 me1 1960 .

25. Bacillatre dysenterle

Gemiddeld aantal in $1958 \mathrm{t} / \mathrm{m} 1962$ opgegeven gevallen van bacillaire dysenterla per 10.000 inwoners op 31 mat 1960.

26. Roodvonk

Gemiddeld antal in $1958 \mathrm{t} / \mathrm{m} 1962$ opgegeven gevallen van roodvank per 10.000 inwoners op 31 mel 1960.

27. Hepat1t1s infectlose

Gemiddeld aental in $1958 \mathrm{t} / \mathrm{m} 1962$ opgegeven gevallen van hepatitis infectlosa per 10.0001 nwaners op $31 \mathrm{mel} 1960$.

Gron_23_t/m_27: Dertien-weken staten van het aantal aangegeven gevallen van besmettel1jke ziekten in: Verslagen en mededelingen betraffende de Volksgezondheld 1958. 1959. 1960, 1961, 1962 en 1953

28. Huwelijkggeboortec1jt.

Gemlddeld aantal wettig levend- en doodgeborenen in $1958 \mathrm{t} / \mathrm{m} 1962$ per 1.000 gehuwde vrouwen van 15 -49

jaer op 31 me1 1960 .

29. Buitenachtel1jk geboortecijfer

Gemiddeld aantal onwettig levend- en doodgeborenen in $1958 \mathrm{t} / \mathrm{m} 1962$ per 1.000 ongehuwde vrouwen $(1 \mathrm{n}-$ clusfef gescheiden vrouwen en weduwen) van 15-49 jaar op 31 mei 1960.

Bron 28.en 29: Total bantel levend- en doodgeborenen - C.B.S., gelichtdrukte tabellen. afd. Bevalkingsstatigtioken: gegevens per gemeente betreffende de loop der bevolking in het jaar $1958,1959,1960,1961$ en 1952 .

Aantal doodgeborenen 1958 en aantal onwettig levend- en doodgeborenen 1958, 1959, 1960, 1961 en 1962 - tellingen van de ofd. Bevolkingsstatistieken van het C.B.S.

30. Sterftecijfer

Indirect naar leeftijd gestandaardiseerd sterfteciffer ${ }^{l}$, berekend over gemiddeld aantal overledenen per leeftijdscategorie in $1958 \mathrm{t} / \mathrm{m}$ 1962. per 1.000 inwoners op 31 mel 1960.

31. Doodgeboorte

Gemiddeld aantol in $1958 \mathrm{t} / \mathrm{m} 1962$ doodgeborenen per 1.000 van het gemiddeld dantal in $1958 \mathrm{t} / \mathrm{m} 1962$ levend- en doodgeborenen.

11. de Jonge: Inlelding tot de medische statist1ek, deel 1. Leiden, 1963. 


\section{Zulgelingensterfte}

Gemiddeld antal overledenen < 1 jaar van $1958 \mathrm{t} / \mathrm{m} 1962$ per 1.000 van net gemiddeld asntal in 1958 $t / m 1962$ levengeborenen.

Bron 30_t/m_32: Aantal overledenen per leeftijdscategorle $1958 \mathrm{t} / \mathrm{m} 1962$ - fotocopleĕn $1958 \mathrm{t} / \mathrm{m} 1962$ van de afd. Bevolkingsstatistleken van het C.B.S.

Aantal levend- en doodgeboranen. C.B.S. gelichtdrukte tabellen. afd. Bevolk1ngsstatistigken: gagevens per gameente betraffende de loop der bevolking in het joar 1950.

$1959,1960,1961$ en 1962.

Aental doodgeborenen 1958 - telling van de ofd. Bevolkingsstatistieken van het C.B.S.

\section{Sterfte ongavalien in het verkeer}

Indirect naar leeft jo gestendaerdiseerde sterftel, berakend over het gemiddeld aontal overladenen door ongevallen met motorvoertulgen in het verkeer (code BE 47a van de kleine internatianale lijst van doordsoorzaken 1955) per leaftijdscategorle in $1958 \mathrm{t} / \mathrm{m} 1962$ per 100.000 1nwoners op 31 me1 1960.

34. Sterfte ongevallen

Indirect naar leeftijd gestondaardisearde sterftel, berekend over het gemiddeld aantal overledenen door ongevallen (code $B E 48 \mathrm{c}$ van de kleine internationale 11jst van doodsoorzaken 1955) per leeft1joscategorle in $1958 \mathrm{t} / \mathrm{m} 1962$ per 100.000 1nwoners op $31 \mathrm{ma1} 1950$.

35. Sterfte kwaadaardige niguwvormingen .

Indirect noar leeftijd gestandaardiseerde sterftal, berekend over het gemiddeld aantal in $1958 \mathrm{t} / \mathrm{m}$ 1962 overledenen, doodsoorzagk kwasdaardige nleuwvormingen (code 104-205 Internationale 11jst van doodsoorzaken 1958) voor de leeft1jdsgrcepen van 40-54 Jaar per 1.000 inwoners van 40-64 jaor op 31 me1 1960 .

36. Sterfte arteriosclerot1sche on degeneratieve nartziekten

Indlrect naar leaftijd gestandaardiseerde sterftel, berekend over het gemiddeld aantal in $1958 \mathrm{t} / \mathrm{m}$ 1962 overledenen. doodsoorzaken artoriosclerotische on degeneratieve hartziaktan (code 420-422) internationale 11 jst van doodsoorzaken 1958) voor de leeft1jdsgroepen van 40-64 jaar per 1.000 inwoners ven 40-64 jaar op 31 me1 1960.

Bron_33_t/m_36: Aantal overledenen naar doodsoorzaken per leeftijdscategorie van 1958 t/m 1962 tellingen van de ofd. Gezondheldsstatistiek van het C.B.S.

\section{VARIABELEN "CIJFERSPRODUCERENDE INSTANTIES"}

1. Sterkte politiecorps

Gemiddeld eentel polit le-ambtenaren over 1956 - 1962 per 10.000 Inwoners op 31 mei 1960.

Bron 1: Het aantal politle-ambtenaren (gemeente- en rijkspolitie) per gemeente in de jaren $1958 \mathrm{t} / \mathrm{m} 1962$ - tellingen afd. Gerechtelijke statistiak van het C.B.S.

\section{Ziekanhuisbeddagen}

Dezo tamel1jk gecompliceerde varlabele is gebaseerd op het aantal in algemene en acodemische zlekenhulzen opgenomen patienten over het jaar 1960 en de maximale opnamecapaciteit van deze zlekenhuizen. Voor elk algemeen of academisch zlekenhuls is berekend:

a. het relatieve andeel van elke onderzoeksgemeente (voor zover daaruit in 1960 patienten in het desbetreffende zlokenhuis waren opgenomen) in de totale rayongrootte van het ziekenhuis;

b. het aantal ophamen blf een bezettingsgraad van 100\%, rakening houdend met de gemiddelde verpleeg duur van het zlekenhuis in 1960 \{100x feitelijk aantal opnemen/feitelijk bezettingsparcentage). Het product van de onder a. berekende fractle met de onder b. berekende maximale opnamecapaciteit geeft per zlekenhuis het aental voor elk van de gemeenten beschikbare beddagen per jaar bif aen bezettingsgraad van $100 \%$. On tot het totaal aantal beschikbara beddagen per gemeente te komen zijn voor elke gemeente de berekende beddegen van alle ziekenhuizen, waarin over 1960 patienten ult de gemeente waren apgenomen, bij elkaar opgeteld.

Dit totale aental beddagen per gemeente is tenslotte, tot verhoudingscljfer per 1.000 inwoners omgerekeno.

Bron.2: Het antal patienten per gemeente per algemeen of academisch ziekenhuls in 1960 - door elgen medewerker verzameld uit gegevens van de onder het Ministerie van sociale Zaken en Volksgezondheid ressorterende "Zlekenhuiscomissie". 
Rayongrootte, feltelljk aantal opnomen en bezettingsgraad per algemeen of academisch zlekenhuis - Geneeshundige Hoofoinspectie van de valksgezondheld: Overzlcht van de gegevens der zlekenhulzen in Nederlend over net Jaar 1950. 's-Gravenhage. oktober 1962

3. Hulsartsendichtheid

Aantal prektizerende hulsartsen per 31 mel 1960 naar gemeente van inwoning per 10.000 fnwoners op 31 mes 1960.

4. Tandartsendschthe1d

Aantal prahtiserande tandartgen per 31 mel 1960 naar gemeente van inwoning per 10.000 inwoners op 31 met 1960 .

Gron_3_en 4: Aantal praktizerende hulsartsen en tandartsen naar gemeente van inwoning - door elgen medewerkers verzameld ult gegevens van de 13 e Algemene Volkstelling 31 mel 1950.

C.B.S. ofd. Algemene Tellingen en Bevolk1ngsstatistiek

5. Wijkverpleegsters

Gemlddeld aunta! w1jkverpleegsters over 1958 - 1952 per 10.000 inwoners.

Dron_5: Aantal wikverpleegsters per gemeente voor de jaren 1958 - 1952 - tellingen van de Geneeskundige Hoofdinspectie voor de volksgezondheid

6. Vroodurouwen

Aantal vroedvratwen of 31 december 1960 naar gemeente van inwoning per 10.000 vrowwen van 15-49 jaar.

Bron 6:

Aantal vroedvrouwen of 31 december 1960 nasr gemeente van inwoning - adresl1jst van vroedvrouwen in Nederland op 31 december 1962. Geneeskundige hoofdinspectie voor de Volksgezondheld. Uitgaande van deze adreslijst zijn met behulp van de mutaties, gepubliceerd in de "Verslagen en mededelingen hetreffende de volksgezondhe1d" van 1951 en 1962, de adtallen vroedvrouwen per 31 december 1960 vastgesteld

7. Afstand psych1atrische 1nrichting

Afstand van de gemeente tot dichtstbijzijnce psychiatrische inrichting met een klinisch centrum in drie afstandscategorleën $(\geqslant 30 \mathrm{~km}$., 15-29 km. en $0-14 \mathrm{~km})$ nemelsbreed met behulp van een passer op de koart gemeten (respectievel1jk score 1,2 en 3 ).

Bron_?:

Psychiatrische inrichtingen met een kilnisch centrum en gemeenten van vestiging Geneeskundige Inspectie voor de Geestelijke Volksgezondheld: Lifst van instituten met een vergunning/aanwijzing Ingevolge de Krankzinnlgenwet 1958

ONAFHANKEL IJKE VARIABELEN

\section{Aantal inwoners}

Ergo.1: $\quad$ C.B.S. 13e Algemene Volkstelling, 31 mei 1960. Deel ?

2. Bevalkingsdichtheid

Aantal Inwoners per $\mathrm{km}^{2}$ land

3. : inwoners grootste woonkern

Aantal inwoners in de grootste woonkern van de gemeente per 100 inwoners op 31 me: 1960

Bron_2_en_3: C.B.S. 13e Algemene volkstelling 31 me1 1950 . Oet 14. voornoanste kenget allen per gemeente. Staatsuitgeverij, 's-Grovennuge. 1966

4. Eebouwingsdichtheid

100 - "Inwoners. woonachtig in versprefde huizen $x$ het dantal woningen op 31 mei $1960 / 100$ per aantal nectaren betouwde oppervlakte van de gemeente op 31 december $\$ 960$.

Bron 4: $\quad$ C.B.S. 13e Algemene volkstelling 31 mei 1960 . Leel 2

C.B.S. 13e Algenene Volkstelling 31 mei 1960. Deel 5 : Huishoudens, pezinnen en waningen B: Voornaamste cijfers per gemeente. De Harr. lelst, 1964

Bodemstatistlek Gemeenteli jke jaarcijfers. 91: Dppervlakte en pelurulk vern de gronden on

31 december 1960 . Gelichtdruhte tabel C.B.S. afd. Landbouwstitistiek

5. woningen in meergezinshuizen

fantal bewoonde woningen in meergazinshuizen per i0n bowoonde woningen in 1956.

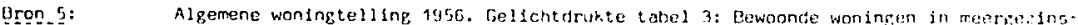

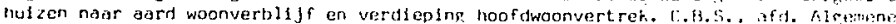
tellingen on bevalkinfsitatistiek 
6. Aantel personen per vertrek

Gemiddeld aental pergonen in bewoonde wonlngen per vertrek op 31 me1 1960.

7. Ratio personen per vertrek 1960/1947

Aantal personen in bewoonde woningen per vertrek op 31 mel 1960 op het aantal personen in bewoonde woningen per vertrek op 31 me1 1947 .

8. Inwoning ten gevolge van de woningnood

Aantal zelfstandige huishoudens (def. 1947) inwonend ten gevolge van de woningnood per 100 zelfstandige huishoudens op 31 me1 1960.

Bron.6.t/m_o: C.B.S. 13e Algemene Volkstelling 31 mel 1960. Deel 5. B

C.B.S. 12e Algemene Volkstelilng $31 \mathrm{mel}$ 1947. Deel 2: Woning - en gezinstelling. B; voornaamste cijfers per gemeente. Stootsultgeverij. 's-Gravenhage. 1949

9. Index sanitaire voorzleningen woningen

Combinatie van de klassen-scores van de frequentleverdelingen van:

- Aantal bewoonde woningen mat privat binnen de woning, doch zonder spoeling en/of ofvoer faecaliën of met privaat bulten de woning of zonder privaet per 100 bewoonde woningen in 1956.

- Aantal bewoonde woningen zonder badgelegenheld per 100 bewoonde woningen in 1956.

Bron.9; Algemene woningtelling 1956, C.B.S. Gelichtdrukte tabellen:

19: Hulshoudens in wonlngen naar wijze van hulsvesting. grootte en wijze van slepen

10: Bewoonde woningen naar aard woonverblijf en oanwezigheld, aard. ligging, enz. van privast

12: Bewoonde woningen noar aerd woonvertliff, agnwezlgheid en aard woonrulmte

10. Index socio-economisch niveau

Combinatie klassen-scores van de frequentieverdelingen van:

- Aantal mannen van 14 jaar of ouder met meer dan lager algemeen vormend onderwijs lexclusief nog dagonderwijs genietenden) per 100 mannen van 14 jaar of ouder 31 mel 1960.

- Aantal employé's per 100 arbeiders (mnl. en vrl.) 31 mel 1960.

- Gemiddeld belastbaar Inkomen per Inwoner 1960.

Bron 10: C.B.S. 13e Algemene Volkstelilng 31 mei 1960. Deel 8: Genoten onderwijs en onderwijsniveau. B: Voornaamste cljfers per gemeente. De Haan, Zeist, 1964

C.B.S. 13e Algemene Volkstelling $31 \mathrm{mel}$ 1960. Deel 10: Eeroepsbevolking. B: Voornaamste

c1jfers per gemeente. De Maan, Ze1st. 1964

C.B.S. Inkomeasverdeling 1960. Regionale gegevens. De Haan, Zeist, 1964

11. * land- en haridarbe1ders

Aantal mannelijke land- en handarbelders per 100 mannel1jke hoofden van huishoudens op 31 mei 1960.

Bron 11: $\quad$ C.B.S. 13e Algemene Volkstelling 31 mel 1960. Deel 10. B

12. Ebelastingplicht1ge inwoners met inkomen $f 5.000,-$

Aantal belastingplichtige Inwoners met een jaarlijks inkomen lager dan $f$ 5.000,- per 100 belastingplichtige inwoners in 1960.

13. Inkomensdiscrepantie

Verhouding gemiddeld inkothen van het kwartiel belastingplichtige lnwoners met de laagste Inkomens op het gemiddelde inkomen van het kwartiel belastingplichtige inwoners met de hoogste inkomens in 1960 , maol 100 .

Deze variabele is gescoord van de hoogste waarde (geringste discrepantie) - score 1 - naar de laagste warde (grootste discrepantie) - score 9.

14. Inkomensdiscrepantie 1960/1946

Rat 10 inkomensdiscrepantie 1960 (z1e 13) op Idem 1946. Deze varlabele is gescoord van laagste waarde (sterkere afname inkomensdiscrepentie) - score 1 - naar noogste waorde (geen of geringe afname inkomensdiscrepantie) - score 9.

Bron $12 t / m, 14:$ C.8.5. Inkomensverdeling 1960. Reglonale gegevens

C.B.S. Gegevens per gemeente betreffende Inkomensverdeling 19n6. De Mtsan, 7e1st. 1952

15. Gemfddeld Inkomen $1960 / 1946$

Rat fo gemiddeld belastbaar inkomen per inwoner in 1960 op geniddeld belastbaar inkamen per inwoner joat

Uron. 15: C.B.S. Inkomensverdeling 1960. Reglanale Regevens

C.B.S. Gegevens per pemeente betreffende inkomensverdeling tiak 
16. Diversiteitscosfficlunt bedrjdfstakken

Som van de gekwadrateerde proporties van de beroepsbevolking werkzoem In de bedrljfstekken landbouw. delfstoffen. Industrle en ambacht, bouwnijverheid, openbare nutsbedrijuen, hendels, bank- en verzekeringswezen, vervoers-, opslag- en communicetlebedrijven en dienstverlening van de totele in de gemeente wonende beroepsbevolking op 31 mel 1960.

Bron 16: $\quad$ C.e.s. 13e Algemene Volkgtelling 31 mei 1960. Gellehtdrukte tabel 15: Beroepsbevolk1ng near bedriffsklasse. positle in het bedrijf en geslacht en noer bedrijfsklasse, gedeeltelijke werkwook an geslacht

17. \& beroepsbevolking in de 5 belengrijkste bedrijfsklagsen

Aantol personen werkzosm in de 5 belangrijkste bedrijfsklassen van de gemeente per 100 tot de, in de gemeente wonende, beroepsbevolking behorende mennen en vrouwen op 31 me1 1960.

Bron 17: $\quad$ C.B.S. 13e Algemene Volksteling 31 mei 1960. Deel 14

18. Bedrijfshoofdenratio

Aantal personen werkend voor elgen rekening per 100 personen warkzasm in loondlenst op 31 mei 1960.

Bron_18: $\quad$ C.B.S. 13e Algemene Volkstelling 31 mei 1960. Deel 10. B

19. werkzaam in 1ndustrie

Aantal mannalijke en vrouwelijke employe's en arbelders werkzeam in de bedriffstak industrle en ambecht per 100 van de In de gementig wonende mannelijke en vrouwelifke employé's en arbeiders op 31 mel 1960.

20. Werkzoom in dienstverlen!ng

Aantal mannelijke en vrouwelijke omployé's en arbelders werkzaam in de bedriffstak dienstverlening par 100 van de in de gemeente wonende mennel1jke en vrouwelljke emoloyé's en arbejders op 31 met 1960.

Bron 19. en_20: C.B.S. 130 Algemene Volkstelling 31 me1 1960. Gelichtdrukte tabel 15

21. Afnemende 1ndustrleliserling 1960/1947

Aantal mannelijke en vrouwelijke employe's en arbeiders, werkzaam in de bedriffstak industrie en ambacht per 100 mennel1jke en vrouwelijke. In de gemeente wonende, employe's en arbeiders op 31 med 1960 op het percentage mannelijke en vrouwelijke employés en orbeiders, werkzeam in de bedrijfstak nijverneld op 34 mei 1947. Hiertoe werden de. In de desbetreffende tabel (10) onderscheiden, bedriffsklassen $01 \mathrm{t} / \mathrm{m} 17$ blj elkear opgeteld, dit met ultzondering von de bedrijfsklessen 04 (bouwn1jverhe1d), 10 (m1jnbouw, veenderjjen, etc.) en 16 (ges-. electriciteits- en woterlejdingsbedrijven), wolke bedrijfsklassen in 1960 als ofzonderlijke bedrljfstakken den wel tot andere bedriffstakken worden gerekend. Bif de scoring van deze varlabele kregen de cijfers $\geqslant 1.00$ de score 0 en de cljfers $\times 1.00$ de score 1 af hoger.

22. Toonemende 1ndustrial1sering 1960/1947

Idem. Bif de scoring van deze variabele kregen de cljfers $\leqslant 1.00$ tezamen de score 0 on de c1jfers $>1.00$ 1 of hoger.

Eron_21.en_22: C. B.5. 13e Algemene Volkstelling 31 me1 1960. Gelichtorukte tabel 15 C.8.S. 12e Algemene Volkstelling 31 mel 1947. Gellchtdrukte tabel 10: Beraepsbevolking naar bedrijfsklossen on positie in het bedriff

23. I werklozen

Cemiddeld aantol geheel werkloze mannen en vrouwen in 1959. 1960 en 1969 per 100 tot de, in de gemeente wonende, beroepsbevolking behorende mannen en vrouwen op $31 \mathrm{mel} 1960$.

24. Rat1o aanbod - vraag arbeldsmarkt

Gem1ddeld aantal geheal werkloze mennen en vrouwen in 1959.1960 en 1961 op het gemiddeld aantal geregistreerde openstoanda oanvragen voor mannelijke en vrouwelijke arbeidskrachten in 1959.1950 en 1969.

Eron_23.en_24; C.B.S. . afd. Soclale statistieken. Telkaarten per gemeente met kwartaalcijfers C.B.S. 13e Algemene Volkstelling $31 \mathrm{me} 1$ 1960. Deel 14

25. E woonforensen

Aantal woonforensen per 100 van de ter plabtse wonende beroepsbevolking op 31 met 1960.

2G. *werkforensen

Aantal werkforensen ner 100 van de ter platse werkende beroepsbevolking op 31 mel 1960.

Qrgn_25_en_26: C.B.S. 13e Algemene volkstelling 31 mel 1960. Deel 14 
27. Outochtons bevolking

Aantal inwoners dat alt1jd in de gemeente heeft gewoond per 100 inwoners op $31 \mathrm{ma1} 1960$.

Bron_27: C.e.S. 13e Algamene Volkstelling $31 \mathrm{mel} 4960$. Deel 3: Geboortegemeente en periode van vestiging in de huldige woongemeente. De Haan. Hilversum. 1966

28. : in buttenland gaboren inwoners

Aantal inwoners dat in het buttenland is geboren per 100 inwoners op 31 met 1960.

Bron 28: $\quad$ C.B.S. 13e Algemene Volkstelling 31 mel 1960. Deel 3

29. Rat10: allochtone bevolking 1960/1947

Aental niet in de huidige woongemeente geboren Inwoners per 100 inwoners op 31 mel 1960 op het percentage niet in de huldige woongemeente geboren Inwoners op 31 mal 1947.

Eron_29: $\quad$ C.B.S. 13e Algemene Volkstelling 31 me1 1960. Deel 3 C.B.S. 12e Algemene volkstelling 31 mel 1947. Gelichtdrukte tabel 8 : Bevolking naar geboorteplaats en geboortbjaar-klasse

30. : bovolkingsgrogl

Toename in Inwonertal 1947-1960 per 100 1nwoners in 1947.

Eron_30:

C.B.S. 138 Algemene Volkstelling 31 mel 1960. Deel 14

C.B.S. 12e Algemene Volkstelling 31 mel 1947. Deel 1: Plaatsel1jke Indeling. B: Voornaamste ciffers per gemeente. Staatsultgever1j, 's-Grovenhage, 1950

31. Tempo bevolkingsgroe1

Diversiteitscoëfflciënt groel inwonertal: som van de gekwadrateerde proporties bevolkingstaeneme per jaar van de totale bevolkingstoename ovor een periode van 12 jaar.

Bron_31: $\quad$ C.8.S. Eevolking der gameenten van Nederland op 1 Januar1 1948 en 1949 t/m 1 januari 1960. De Maan. Utrecht. $1949 \mathrm{t} / \mathrm{m} 1960$

32. Diversiteitscoüflciont sociale beroepsgroepen

Som van de gekwadratearde proporties van de sociale beroepsgroepen van de mannelijke hoofden van hulshoudens van het totale aantal mennelijke hoofden van huishoudens op 31 me1 1960.

Eron_32: $\quad$ C.8.5. 13e Algemens Volkstelling 31 mex 1960. Deel 10. B. Tabel 3 . kolomen 2 t/m 15

33. D1versite1tgcoëfficlënt uitgebrachte stamen 29 Kamerverklezingen 1959

Som van de gekwadrateerde proporties bij de Tweede Kamerverkiezingen 1959 op de politieke partijen ultgebrachte stemen van het totaal asital ultgebrachte stemen op 12 maart 1959.

Bron_33: $\quad$ C.3.S. Statistiek der verkiezingen 1959.

34. Etemen ultgebracht op P.V.d.A., P.S.P. en C.P.N.

Gemiddelde som van de percenteges geldig ultgebrachte stemen op de P.V.d.A., P.S.P. en C.P.N. Tweede Kamerverkiezingen op 12 maart 1959 en op 15 mei 1963

Bron 34: $\quad$ C.B.S. Statistiek der verkiezingen 1959

C.B.S. Statistiek der verkiezingen 1963

35. Rooms-Katholleken

Aantal Rooms-Katholleken per 100 inwoners op 31 me1 1960.

Bron_35: C.B.S. 130 Algemene Volkstelling 31 mei 1960. Deel 7: Kerkel1jke gezindte. B: Voornaamste ciffers per gemeente. De Haan. Ze1st, 1963

36. Seculertserlng 1960/1947

Aantal onkerkel1jken per 100 1nwoners op 31 mex 1960 op het percentage onkerkel1jken op 31 me1 1947.

Bron_36: $\quad$ C.B.S. 13e Algemene Volkstelling 31 mel 1960. Deel 7. B

C.B.S. 12e Algemene Volkstelling $31 \mathrm{mel}$ 1947. Deel 5: Kerkelijke gezindten. 8: Voornaomste cijfers per gemeente. Staatsuitgeverif. 's-Gravenhage. 1950

37. Inwoners van $15-49$ jaar

Aantal Inwoners van $15-49$ jear per 100 inwoners op 31 me1 1960.

Bron 37: $\quad$ C.B.S. 13e Algemene Volkstelling 31 mel 1960. Gelichtorukte tabel 3: Bevolking noar burgerlijke staat, geslacht en leeftijo

38. Bejaordenratio

Aantal inwoners van 65 joar of ouder per 100 inwoners op het dantal inwoners jonger dan 20 joar per 100 Inwoners op 31 mei 1960 .

Q̣ron 38: C.B.S. 13e Algemene Volkstelling 31 mei 9960 . Deel 14 
39. VergrjJzing bevolking 1960/1947

Aantel 1nwoners van 65 Jaar of ouder per 100 1nwoners op $31 \mathrm{mel} 1960$ op het percentege 1nwoners van 65 Jaer of ouder op 31 mal 1947.

Bron 39: $\quad$ C.8.S. 138 Algemens Volkstelling 31 mel 1960. Deel 14 C.B.S. 12e Algemene Volkstelling 31 mei 1947. Gellchtdrukte tabal 4: Bevolking naor leeftijdsklessen en burgerlijke steot. Afd. Algemene Tellingen

40. Sex-ratio

Aentol vrouwen per 1 Januari 1961 op het oental mannen per 1 januer1 1969.

Gron 40: C.B.S. Bevolk1ng der gemeanten van Nederland op 1 januar1 1961. De Haan, Utrecht, 1961

41. 3 ongehuwden

Aentel noolt gehuwd geweest z1jnde personen van 20 jaer of ouder per 100 inwonars van 20 joar of ouder op $31 \mathrm{mel} 1960$.

42. I gehuwd geweest zijnden

Aantal gehuwd geweest zijnde personen van 20 jaar of ouder per 100 Inwoners van 20 faer of ouder op 31 mei 1960 .

Ergn.41.en_42: C.B.S. 13e Algemene Volkstelling 31 mel 1960. Gelichtdrukt 8 tabel 3

43. I hectaren porken en plantsoenen

Aentel hectaren perken en plentsoenen per 100 hectaren bebouwde oppervlakte van de gemeente op 31 december 1960.

44. I hectoren bos, rlet en biezen en woeste gronden

Aental hectaren bos, rlet en biezen en woeste gronden per 100 hectaren totala oppervlakte van de gemeente op 31 december 1960.

45. 3 hectaren water breder den 6 meter

Aantal hectoren water breder den 6 meter per 100 hecteren totole oppervlekte van de gemeente op 31 december 1960.

Bron $43 . t / m$. 45: Bodemstatistiek. Gelichtdrukte tabol C.B.S., afd. Landbouwstatistlek

46. Aantol vestigingen horecabadrifven

Aantal vestigingen in de gemeente behorend tot de bedriffsklasse "Horece" op 15 oktober 1963 per 10.000 Inwoners op 31 mel 1960 .

Bron 46: C.B.5. 3e Algemene bedrijfstelling 15 oktober 1963. Gelichtdrukte tabel 6: Vestigingen, werkzome personen, vestigingen nasr het aontal daorin werkzome personen

47. Aantal bioscopen

Aantal bioscopen in de gomeente in jul1 1960 per 10.000 1nwoners op 31 me1 1960.

Bron 47: Noom- en odreslijst van de Nederlandse bloscoopbond, jull 1960

48. Aantal sportvelden. -banen en -hallen

Aantal sportvelden, -banen en hallen in de gemeente op 1 september 1963 per 10.000 inwoners op 31 mel 1960.

49. Aantol zweminrichtingen

Aantal zweminrichtingen voor openbaar gebrulk in de gemeente op 1 september 1963 per 10.000 inwoners op 31 mei 1960.

50. Aantal gymnastieklokalen

Aantal gymnastieklokalen beschikbaar voor verenigingen in de gemente op 1 september 1963 per 10.000 Inwoners op 31 mel 1960.

Bron_46.5/m.50: C.8.S. De sportaccomodatio in Nederlend op 1 september 1963. De Haan, Zelst, 1964

51. Aanwezigheid en afstand schouwburgen en concertzalen

Gewogen score per gemeente: gemeenten zonder, met 1,2 of meer dan 2 schouwburgen en/of concertzalen binnen de algen granzen kregen respectievelijk score $0,1,2$ of 3. Afstand gemeente tot andere gemennten met één of meer schouwburgen en/of concertzalen frekening houdend met "natuurlijke barrí̀res" hemelsbreed gemetenl - 4 categorleën: $0 \mathrm{~km}$. leigen pemeentel, $1-9 \mathrm{~km}$. . 10-19 km. nn 20 of neer km., g,ewogren met

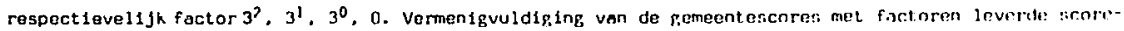
breadte op van 0-24: hogere score = betere besshikking van gemecnte-hevolking aver s.rinuwlur): in/nf concertzanl. 
Bron_51: Verenigingenboekje 1964. Ministerie van Onderwijs, Kunsten en Wetenscheppen, Den Haeg. 1964

52. Aantal bibliotheken of bibliotheakposten

Aantel bibllotheken of blbllotheekposten in de gemeente in 1980 per 10.000 inwoners op 31 me1 1960.

Bron 52: Leeszaoljearbogkje 1959-1960, uitgegeven door de Centrale Vereniging voor Openbare Bibliotheken. 's-Gravenhage, juli 1960; Verslag van de Nut scommissie voor bibliotheekwezen over het dienstjoar 1960-'61. Ansterdami Jaarverslag van de Centrale Vereniging voor Relzende bibllotheken 1960. Amsterdam; Jaarverslagen Plat telandsbibllotheek 1960; opgavan van: de St1cht1ng C.J.V. Lectuurvoorzlening. rasultaten enquatel1jsten ma1 1960, de St. Vincentiusvereniging betreffende ultleenbibllotheken 1960, het Christelijk Lectuurcentrum 1960, de heer A.J. Lucas. "Het Boekhu1s". Ansterdam betreffende erkende commerclile leesblbliotheken en boekhandels-annex-leesbibliotheken 1960; de Provinciale Bibliotheak Centrale 1960 (ook jearverslagen)

53. Aantal zang- en oratorlumveren1gingen

Aantal zang- en oratoriumverenfgingen in de gemeente in 1960 per 10.000 inwoners op 31 mel 1960.

Qrron_53:

Opgaven van: Koninklijk Zangersverbond; Maatschapplf tot Bevordering der Ioonkunst: Bond van Arbeldergzangveren1gingen; Bond van Katholleke Zangverenlgingen in Nederland: Koninklijke Bond van Zang- en Oratoriumverenigingen in Nederland; Comité van Acht; Landelijke Organisatie van Provinciale en Regionale Zangersbonden; Joerboek 1960 - Koninklijke Bond van Christel1jke Zang- en Oratoriumverenigingen

54. Aantal harmonle- en fanfaregezelschappen

Aantal hamenie- en fanfaregezelschappen in de gemeenten in 1960 per 10.000 1nwoners op 31 mei 1960.

Bron 54: Opgaven van: Federatie van Katholieke Muziekbonden in Nederland: Nederlandse Federat 1e van Christelijke Muziekbonden: Algemene Nederlandse Unie van Muziakverenigingeni KoninkIj ke Federatie van Harmonie- en Fanfaregezelschappen

55. Agntal amateurtoneelverenlgingen

Aantal amateurtaneelverenigingen in de gemeente in 1960 per 10.000 inwoners op 31 mel 1960 .

Bron_55: Opgeven van: Nederlands Centrum voor Amateurtoneel (voorheen: Nederlandse Amateur Toneel Unie), Werkverbond Kathollek Amateurtoneel

56. Aantal clubhuizen

Aantel clubhulzen voor het bijzondere Jeugdwerk in de gemeente in 1960 per 10.000 inwoners van 10-20 Jaar op $31 \mathrm{mel} 1960$.

Eron_56: Stichting Evangelisch Herstel en Opbouw: Landelijk overkoepelend orgaan voor het Gerefor meerd bijzonder Jeugd- en Gezinswerk; verslag over de periode 1 september 1960 tot

1 september 1961. Opgeven van: Nederlandse Bond van Sociaal-cultureel Vormingswer:

Salco-Stichting Samenwerking Landelijke Centrale organen voor wijk-, buurt- en clubhuiswerk.

C.B.S. 13e Algemene Volkstelling 31 me1 1960. Gellchtdrukte tabel 3

57. Gemiddelde klassedeler lager onderwils

Xlasse-indaling van het gemiddeld astal leerlingen van het lager onderwijs per onderwijzer in 1959.

Bron_57: C.B.S. Statistiek van de school- en Klassegrootte bif het B.1.0. 1933-1959. De Moan. Zeist. 1960

58. Index onderwi Isvoorziening 1.t.o. / 1.n.o.

Comblnatle van de klassen-lndeling scores van:

- Aantal jongens en malsjes dat in de elgen woongemeente 1.t.o. / 1.n.o. volgt per 100 joigens en meisjes uit de gemeente die l.t.o./ l.n.o. volgen in 1962/.63.

- Aantal uit andere gemeenten ofkomstige jongens en melsjes dat in de gemeente 1.t.o. / 1.n.o. voligt per 100 jongens en melsjes die in de gemeente 1.t.o. / 1.n.o. volgen in 1962/.63.

59. Index onderwijsvoorziening U.L.D.

Idem voor U.L.O.

Fis. index onderwijsvoorplening v.h.m.o.

IJem voor v.h.m.o.

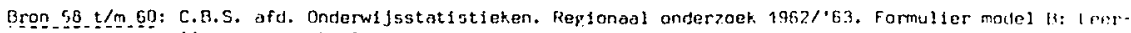
ingen per school en woongemeente 
61. : onkerkelijka bevolking

Aantal onkerkeligken per 100 inwoners op $31 \mathrm{mel} 1960$.

Bron 61: C.B.S. 13a Algamene volkstelling 31 me1 1960. Deel 7.B

62. I berogpsbevolking met mear dan allean lager onderwijs

Aental mannen en urouwen van 14 jear of ouder met een beroep en tenminste een akte of diplome voor meer ultgebreid leger ondenwljs of een lagere beroepsopleiding per 100 mennen en vrouwen van 14 jasr of ouder met een beroep op 31 mel 1960.

Bron_62: $\quad$ C.B.S. 13e Algemene Volksteliling 31 me1 1960. Deel 8.B

63. Index normatleve 1ntegratle

Combinatie klassen-scores van de frequentleverdelingen ven:

- I outochtone bevolking.

- Olversite1tscoëfficlënt soc1ole beroepsgroepen.

- : onkerkelljke bevolk1ng (ongescoord).

Bron 53: 210 onafhankelijke variabelen 27, 32 en 61

64. Index economische diversiteit

Combinatle klassen-scores van de frequentieverdelingen van:

- Olversiteltscö̈flclënt bedrijfstakken (amgescoord).

- beroepsbevolking in de 5 belangrijkste bedrijfsklessen (ongescoord).

Bron.64: Zie onghankelijke variabelen 16 an 17

65. Index c1ffersproducerende instanties

Comblnatle klassen-scores van de frequentleveroelingen van:

- Starkte politiecorps.

- Zlekenhulsbeddagen.

- Huisert sendichthe1d.

- Wijkverpleegsters.

- Vroedvrouwen.

- Afstand psychlatrische inrichting.

Bron 65: 21e variobelen "cijfersproducerende Instanties"1, 2, 3, 5, 6 en 7 
RESULTATEN ORTHOGONALE COMPONENTEN-ANALYSE, UITGEVOERD OP DE CORRELATIEMATRIX VAN 3O GEDRAGSVARIABELEN VOOR 176 NEDERLANOSE GEMEENTEN

\begin{tabular}{|c|c|c|c|c|c|c|c|c|}
\hline \multirow{3}{*}{ Variabelen } & \multicolumn{8}{|c|}{ Correlatiematrix } \\
\hline & \multicolumn{4}{|c|}{ Principale componenten } & \multicolumn{4}{|c|}{ Vorimax rotetie } \\
\hline & $\Gamma_{I}$ & $F_{I I}$ & $F_{\text {III }}$ & $n^{2}$ & $F_{I}$ & $F_{\text {II }}$ & $F_{\text {III }}$ & $h^{2}$ \\
\hline Echtscheldingen & .85 & -.24 & -.04 & .70 & .88 & .10 & .05 & .78 \\
\hline Huwal1jksgeboortec1jfar & -.63 & .29 & .12 & .49 & -.70 & .03 & .04 & .49 \\
\hline Em1grot1o & .67 & .01 & -.23 & .50 & .64 & .24 & -.18 & .50 \\
\hline N1et uitgebrachte stemen & .62 & -.21 & .07 & .43 & .64 & .06 & .14 & .43 \\
\hline Migrotie & .60 & -.20 & -.01 & .40 & .63 & .05 & .06 & .41 \\
\hline Index egresgiave migdrijuen & -.61 & .28 & -.39 & .55 & -.63 & -.02 & -.38 & .55 \\
\hline Buitenechtel1jk geb.c1jfer & .69 & .05 & -.04 & .48 & .82 & .39 & -.00 & .48 \\
\hline Scheldingen tafel en bed & .66 & .11 & .02 & .45 & .56 & .36 & .05 & .45 \\
\hline Sterfte verkearsangevallen & -.47 & .16 & .25 & .31 & -.52 & -.01 & .20 & .39 \\
\hline $\operatorname{Sch} x z$ of $\operatorname{ren} 1 \theta$ & .47 & -.17 & -.01 & .25 & .49 & .02 & .05 & .25 \\
\hline Neurogen & .38 & -.21 & -.11 & .20 & .44 & -.06 & -.05 & .20 \\
\hline Affectiove psychosen & .41 & -.06 & .07 & .18 & .39 & .11 & .10 & .18 \\
\hline Afgekeurden mil. dienstplieht & -.28 & .45 & .29 & .35 & -.44 & .35 & .20 & .35 \\
\hline Vermogensm1sdrijven & .68 & .44 & .09 & .64 & .44 & .67 & .07 & .84 \\
\hline Sexuele misdrijuen & .37 & .58 & .06 & .48 & .12 & .68 & -.00 & .48 \\
\hline Selmonellosen & .21 & .58 & .39 & .53 & -.07 & .66 & .39 & .54 \\
\hline Agressiove misdrijuen & -.02 & .74 & -.26 & .62 & -.27 & .64 & -.37 & .62 \\
\hline Ongeldige en blanco stemen & .38 & .48 & -.20 & .41 & .19 & .56 & -.24 & .41 \\
\hline Opname A-zlakanhuis & .42 & .36 & -.25 & .37 & .28 & .47 & -.27 & .37 \\
\hline Dysenterie & .16 & .46 & .54 & .53 & -.09 & .55 & .47 & .53 \\
\hline Afgek. mil. diengtpl. s-5 & .08 & -.04 & .52 & .23 & .03 & .06 & .52 & .28 \\
\hline Starfte ongevalien & .09 & .22 & -.46 & .27 & .05 & .18 &.,- 49 & .27 \\
\hline Roodvonk & .31 & -.17 & .39 & .28 & .30 & .01 & .49 & .28 \\
\hline Hepet1tis Infect1osa & .05 & -.04 & .36 & .13 & .02 & .02 & .36 & .13 \\
\hline Doodgeboorte & -.20 & -.12 & .36 & .18 & -.18 & -.15 & .36 & .18 \\
\hline Jeugdcriminalitalt & .36 & .03 & .30 & .22 & .29 & .20 & .31 & .22 \\
\hline Zelfmoord & .13 & -.36 & .08 & .15 & .24 & -.27 & .14 & .15 \\
\hline Zulgelingenstarfte & -.12 & .25 & -.14 & .10 & -.19 & .17 & -.18 & .10 \\
\hline Sterfte hart- en vatziekten & .42 & .20 & -.11 & .23 & .32 & .33 & -.11 & .23 \\
\hline Sterfte kwoodoardige nieuwv. & .28 & .14 & .05 & .10 & .20 & .24 & .05 & .10 \\
\hline Elgenwaarden & 5.95 & 2.96 & 1.99 & & 5.47 & 3.39 & 2.02 & \\
\hline
\end{tabular}


Bijlage IV-1

RANGORDENING GEMEENTEN VAN HOGE NAAR LAGE FAKTORSCORES, INGEDEELD IN KWARTIELEN

Scores faktor vluchtgedrag per gemeente

\begin{tabular}{|c|c|c|c|}
\hline \multicolumn{2}{|c|}{ Vierde kwartiel $(719-570)$} & \multicolumn{2}{|c|}{ Derde kwartiel (565-498) } \\
\hline Gemeenten & Scores & Gemeenten & Scores \\
\hline Hilversum & 719 & Purmerend & 565 \\
\hline Zandvoort & 719 & Hillegom & 565 \\
\hline Voorburg & 719 & Sliedrecht & 565 \\
\hline Vlissingen & 682 & Appingedam & 563 \\
\hline Blaricum & 672 & Harlingen & 561 \\
\hline Baam & 671 & Landsmeer & 558 \\
\hline Bergen & 668 & Sneek & 553 \\
\hline Haarlem & 568 & Goes & 553 \\
\hline Leiden & 668 & Heer & 553 \\
\hline Heemstede & 664 & Kampen & 550 \\
\hline Driebergen/R1 jsenburg & 660 & Maasslu1s & 550 \\
\hline Arnhem & 558 & Oost-en West-Soubrug & 550 \\
\hline Bussum & 657 & Krommen18 & 547 \\
\hline Koog aan de Zaan & 652 & Hendrik Ido Anbacht & 547 \\
\hline Naarden & 652 & Enkhutzen & 544 \\
\hline Groningen & 649 & Bolsward & 543 \\
\hline $\mathrm{Delft}$ & 645 & Gouda & 543 \\
\hline Alkmaar & 640 & Hengelo (0) & 541 \\
\hline Hoorn & 637 & Leerdem & 539 \\
\hline $\operatorname{Delfz} f j 1$ & 636 & Harderwijk & 537 \\
\hline Vloordingen & 636 & Meppe 1 & 533 \\
\hline Leiderdorp & 626 & Oostzaan & 533 \\
\hline Leeuwarden & 625 & Dubbeldam & 532 \\
\hline Laren (NH) & 625 & Assen & 531 \\
\hline Dordrecht & 625 & Alphen aan de Rijn & 526 \\
\hline Diemen & 621 & 's-Gravenhage & 526 \\
\hline Zutphen & 613 & Eelde & 523 \\
\hline Zaandam & 613 & Maasbracht & 523 \\
\hline Middelburg & 610 & Axel & 521 \\
\hline Wormerveer & 604 & Coevorden & 520 \\
\hline Zw1 Jndrecht & 603 & Winschoten & 518 \\
\hline Breda & 600 & Doesburg & 518 \\
\hline Zwolle & 599 & Schagen & 518 \\
\hline 's-Hertogenbosch & 599 & Helmond & 518 \\
\hline Eifgelshoven & 599 & Boskoop & 516 \\
\hline Gorinchem & 589 & Geleen & S16 \\
\hline Wageningen · & 585 & Zal tbommel & 515 \\
\hline Krimpen ean de IJssel & 583 & Oud Befjerland & 509 \\
\hline Areukelen & 577 & Brunssum & 507 \\
\hline Weesp & 574 & Maarssen & 506 \\
\hline Deventer & 572 & Spljkenisse & 504 \\
\hline lochem & 571 & Hardinxveld/Glessendam & 502 \\
\hline Almelo & 570 & Zierikzee & 501 \\
\hline Middelharnis & 570 & Waddinxveen & 498 \\
\hline
\end{tabular}


Scores faktor vluchtgedrag per gemeente

\begin{tabular}{|c|c|c|c|}
\hline \multicolumn{2}{|c|}{ Tweede kwartiel (497-430) } & \multicolumn{2}{|c|}{ Eerste kwartiel $(429-270)$} \\
\hline Gemeenten & Scores & Gameenten & Scores \\
\hline Laren (G) & 497 & Cuyk en St. Agatha & 429 \\
\hline Roermond & 494 & Beilen & 428 \\
\hline Lemsterland & 492 & Valkenswaard & 426 \\
\hline Víanen & 492 & Zundert & 420 \\
\hline Zoetermeer & 492 & Dinxperlo & 419 \\
\hline Sittard & 492 & Klundert & 419 \\
\hline Ut tgeest & 491 & Veldhoven & 417 \\
\hline Waalre & 488 & Grootebroek & 413 \\
\hline Hoogkerk & 486 & Hulssen & 411 \\
\hline Steenw1jk & 486 & Golrle & 408 \\
\hline Sassenheim & 484 & Omnen & 407 \\
\hline Geldermalsen & 483 & IJsselstein & 400 \\
\hline Schoonhoven & 482 & Zel hem & 397 \\
\hline Veensndaal & 480 & Veghel & 392 \\
\hline Strijen & 480 & Rijnsburg & 391 \\
\hline Dokkum & 479 & Hengelo $(\mathrm{G})$ & 388 \\
\hline E1jsden & 476 & Zuldwolde & 387 \\
\hline Oisterw $1 j k$ & 475 & Made en Drimmelen & 379 \\
\hline Hattem & 474 & Heerhugowaard & 378 \\
\hline Vinkeveen en Waverveen & 471 & Markelo & 372 \\
\hline Heenskerk & 470 & Hilvarenbeek & 372 \\
\hline Ruurlo & 468 & Olst & 370 \\
\hline 's-Gravendeel & 468 & Heeze & 370 \\
\hline De Lier & 467 & Ambt Delden & 369 \\
\hline Boxtel & 466 & Susteren & 369 \\
\hline Assendelft & 465 & Denekamp & 368 \\
\hline Waelw1jk & 465 & Rijssen & 368 \\
\hline Borculo & 463 & Dalfsen & 358 \\
\hline Hulst & 462 & Asten & 356 \\
\hline Culemborg & 460 & Oidam & 352 \\
\hline NLeuwe Pekela & 456 & Bunschoten & 352 \\
\hline Groenlo & 455 & Schijndel & 351 \\
\hline Ouivan & 452 & Son en Breugel & 345 \\
\hline Langedijk & 452 & Tubbergen & 344 \\
\hline Neede & 449 & Smilde & 338 \\
\hline Holten & 447 & W1 the & 335 \\
\hline Vorden & 444 & Staphorst & 333 \\
\hline Oss & 444 & Eersel & 332 \\
\hline Bome & 440 & Weerselo & 319 \\
\hline Oldenzaal & 440 & Heesch & 305 \\
\hline Elbergen & 439 & Urk & 303 \\
\hline Dude Pekela & 438 & Elsloo & 300 \\
\hline Goor & 436 & Bergeyk & 297 \\
\hline Swalmen & 430 & Maasdriel & 270 \\
\hline
\end{tabular}


Scores faktor agressief gedrag per gemeente

\begin{tabular}{|c|c|c|c|}
\hline \multicolumn{2}{|c|}{ V1erde kwartiel (780-559) } & \multicolumn{2}{|c|}{ Derde kwart1el $(555-482)$} \\
\hline Gemeenten & Scores & Gemsenten & Scores \\
\hline Helmond & 780 & Leiden & 555 \\
\hline Urk & 770 & Zierikzee & 551 \\
\hline E1jgelshoven & 754 & Goirle & 550 \\
\hline Roermond & 739 & Hoorn & 549 \\
\hline Brunssum & 735 & Cuyk en St. Agatha & 545 \\
\hline Sittard & 734 & Grootebroek & 544 \\
\hline Oss & 717 & Vlissingen & 542 \\
\hline 's-Hertogenbosch & 693 & IJsselstein & 542 \\
\hline Maesdriel & 691 & Alkmaar & 537 \\
\hline Oude Pekela & 689 & Waalw1jk & 537 \\
\hline Breda & 682 & Laren $(N H)$ & 534 \\
\hline Waal re & 674 & Oud Beiferland & 534 \\
\hline Dordracht & 659 & Didam & 531 \\
\hline Heer & 658 & Klundert & 529 \\
\hline Boxtel & 657 & Middelburg & 528 \\
\hline Schijndel & 656 & Heeze & 528 \\
\hline Meppe1 & 644 & H1lversum & 527 \\
\hline Elsloo & 641 & Olst & 527 \\
\hline Assen & 638 & Kampen & 525 \\
\hline Geleen & 635 & Rijssen & 525 \\
\hline Oisterwijk & 633 & Vianen & 524 \\
\hline Hulst & 632 & Geldemalsen & 524 \\
\hline Zal tbommel & 626 & Oldenzaal & 521 \\
\hline Heesch & 623 & Steenwijk & 519 \\
\hline Arnhern & 621 & Leeuwarden & 515 \\
\hline Susteren & 619 & Nleuwe Pekela & 514 \\
\hline Gron1ngen & 616 & Hengelo [0] & 513 \\
\hline Valkenswaard & 607 & Staphorst & 511 \\
\hline Deventer & 604 & Zaandam & 510 \\
\hline Haarlem & 601 & Maasbracht & 509 \\
\hline Son en Brougel & 598 & Bussum & 507 \\
\hline Veldhoven & 594 & Wageningen & 506 \\
\hline Zandvoort & 592 & Lochem & 505 \\
\hline Almelo & 586 & Gorn1chem & 504 \\
\hline Swalmen & 585 & Blaricum & 502 \\
\hline Veghel & 585 & Wijhe & 502 \\
\hline Zutphen & 584 & Asten & 498 \\
\hline Gouda & 583 & Weesp & 497 \\
\hline Doesburg & 581 & Goes & 497 \\
\hline Leerdam & 578 & Eersel & 492 \\
\hline Culemborg & 571 & Heemstede & 486 \\
\hline Winschoten & 563 & Made en Drimmelen & 488 \\
\hline Bergeyk & 562 & Smilde & 484 \\
\hline Maarssen & 559 & Harderwijk & 482 \\
\hline
\end{tabular}


Scores faktor agressief gedrag per gemeente

\begin{tabular}{|c|c|c|c|}
\hline \multicolumn{2}{|c|}{ Tweede kwart1el $(481-434)$} & \multicolumn{2}{|c|}{ Eerste kwartial $(430-32 B)$} \\
\hline Gemeenten & Scores & Gemeenten & Scores \\
\hline Sneek & 481 & Duiven & 4.30 \\
\hline Bunschoten & 479 & Hendrik Ido Ambecht & 429 \\
\hline Zundert & 477 & Koog ean de Zaen & 427 \\
\hline Harlingen & 476 & Schagen & 419 \\
\hline Maassluis & 476 & Zelhem & 419 \\
\hline Beern & 475 & Purmerend & 418 \\
\hline Zwolle & 474 & Beilen & 418 \\
\hline Driebergen/R1J senburg & 473 & Alphen aan de Rijn & 416 \\
\hline Heemskerk & 471 & Weerselo & 413 \\
\hline Borna & 471 & Tubbergen & 412 \\
\hline Wormerveer & 469 & Oost- en West-Soubrug & 409 \\
\hline Spijkenisse & 469 & Hattem & 407 \\
\hline Boskoop & 467 & 's-Gravenzande & 406 \\
\hline E1jsden & 467 & Zoetermeer & 406 \\
\hline Lems terl and & 466 & Sessenheim & 399 \\
\hline Landsmeer & 465 & Henge 10 (G) & 399 \\
\hline Middelharnis & 464 & Bolswerd & 398 \\
\hline Dokkum & 464 & Dostzaan & 398 \\
\hline Rijnsburg & 464 & Delf $z 1\} l$ & 397 \\
\hline Groenlo & 456 & Hardinxveld/Giessendam & 396 \\
\hline Delft & 454 & Uitgeest & 395 \\
\hline Vlaardingen & 452 & Voorburg & 394 \\
\hline Kromenia & 452 & Leiderdorp & 389 \\
\hline Goor & 452 & Breukelen & 389 \\
\hline Eelde & 451 & Coevorden & 387 \\
\hline Eibergen & 449 & Denekamp & 386 \\
\hline ZwIJndrecht & 446 & Heerhugowaard & 381 \\
\hline Axel & 448 & Appingedem & 379 \\
\hline Hoogkerk & 448 & Assendelft & 377 \\
\hline Hillegom & 447 & Waddinxveen & 375 \\
\hline Enkhuizen & 446 & Strijen & 371 \\
\hline Dalfsen & 446 & 's-Gravendeel & 365 \\
\hline Sliedrecht & 444 & Zuidwolde & 365 \\
\hline Krimpen aan de IJssel & 443 & Markelo & 359 \\
\hline Huissen & 443 & Holten & 355 \\
\hline Naarden & 440 & De Lier & 354 \\
\hline Diemen & 440 & Ommen & 349 \\
\hline Veenendaal & 439 & Dubbeldam & 343 \\
\hline H1 Ivarenbeek & 439 & Laren (G) & 339 \\
\hline Dinxperlo & 437 & Langedijk & 336 \\
\hline Arnbt Delden & 437 & Neede & 335 \\
\hline Schoonhoven & 436 & Vorden & 3.35 \\
\hline Vinkeveen en Waverveen & 435 & Borculo & 333 \\
\hline Bergen & 434 & Ruurlo & 328 \\
\hline
\end{tabular}


Scores faktor vatbaarheid per gemeente

\begin{tabular}{|c|c|c|c|}
\hline \multicolumn{2}{|c|}{ Vierde kwartiel (784-581) } & \multicolumn{2}{|c|}{ Derde kwartie) $(578-490)$} \\
\hline Gemeenten & Scares & Gemeenten & Scores \\
\hline Wijhe & 784 & 0 ss & 578 \\
\hline Heesch & 765 & Zuldwolde & 573 \\
\hline Staphorst & 725 & Schagen & 572 \\
\hline Son en Breugel & 722 & Alphen aan de Rijn & 568 \\
\hline Smilde & 693 & Rijssen & 566 \\
\hline Eibergen & 693 & Krimpen aan de IJssel & 565 \\
\hline Harderw1jk & 692 & Gorinchem & 553 \\
\hline Dalfsen & 681 & Lemsterland & 558 \\
\hline Ommen & 681 & Laren $(\mathrm{NH})$ & 556 \\
\hline Goirle & 665 & Dost- en West-Soubrug & 556 \\
\hline Diemen & 661 & Beilen & 553 \\
\hline Haarlem & 659 & Nieuwe Pakela & 552 \\
\hline Eelde & 653 & Schoonhoven & 551 \\
\hline Koog aan de Zaan & 650 & Hilversum & 549 \\
\hline Dostzaan & 649 & Valkenswaerd & 547 \\
\hline Groningen & 647 & Harlingen & 544 \\
\hline Veldhoven & 640 & Winschoten & 541 \\
\hline Alkmaer & 623 & Maasdriel & 537 \\
\hline Heemstede & 619 & Langedijk & 537 \\
\hline Wormerveer & 619 & Hettem & 530 \\
\hline Zelhem & 619 & Oude Pokela & 522 \\
\hline Urk & 614 & Eersel & 522 \\
\hline Naarden & 614 & Dordrecht & 521 \\
\hline Lelden & 613 & Denekamp & 521 \\
\hline Zaandam & 610 & Kampen & 520 \\
\hline Leeuwarden & 605 & Voorburg & 519 \\
\hline Assen & 604 & Veghel & 517 \\
\hline Steenwijk & 601 & Zutohen & 515 \\
\hline Vorden & 600 & Bergeyk & 514 \\
\hline Dud-Beiferland & 593 & Middelburg & 513 \\
\hline Hengelo (G) & 593 & Dokkum & 509 \\
\hline Zwolle & 592 & Ambt Delden & 509 \\
\hline Woalre & 591 & Arnhem & 507 \\
\hline Hilvarenbeek & 589 & Bearn & 506 \\
\hline Lochem & 588 & Assendelft & 506 \\
\hline Bussum & 587 & Merkelo & 501 \\
\hline Sneek & 586 & Klundert & 499 \\
\hline Deventer & 584 & Oriebergen/R1j senburg & 499 \\
\hline Meppel & 583 & Borculo & 499 \\
\hline 's-Hertogenbosch & 582 & Appingedam & 497 \\
\hline Zandvoort & 582 & Gouda & 496 \\
\hline Olst & 582 & De Lier & 495 \\
\hline Hillegom & 589 & Zoetermeer & 491 \\
\hline Waddinxveen & 581 & Ruurlo & 490 \\
\hline
\end{tabular}


Scores faktor vatuaarheid per gemeente

\begin{tabular}{|c|c|c|c|}
\hline \multicolumn{2}{|c|}{ Tweede kwartiel $(489-429)$} & \multicolumn{2}{|c|}{ Eerste kwertiel $(428-265)$} \\
\hline Gemeenten & Scores & Gemeenten & Scores \\
\hline Heerhugowaard & 489 & Laren (G) & 428 \\
\hline Hoogkerk & 487 & Holten & 424 \\
\hline Weerselo & 487 & Els100 & 423 \\
\hline Geldermalsen & 486 & Vinkeveen en Woverveen & 423 \\
\hline Vlaardingen & 486 & Strijen & 422 \\
\hline Hengelo $(0)$ & 485 & Zal tbommel & 420 \\
\hline Weesp & 485 & Heeze & 419 \\
\hline Helmond & 482 & Hardinxveld/Giessendam & 417 \\
\hline Schijndel & 482 & Huissen & 415 \\
\hline Oisterw1jk & 482 & Waslwijk & 412 \\
\hline $\mathrm{Delft}$ & 482 & Neede & 411 \\
\hline Heor & 479 & Hulst & 408 \\
\hline Enkhuizen & 476 & Purmerend & 407 \\
\hline Zlerikzee & 475 & Vlissingen & 406 \\
\hline Landsmeer & 474 & Brunssum & 405 \\
\hline Maerssen & 473 & Dulven & 403 \\
\hline Rijnsburg & 473 & 's-Gravendeel & 401 \\
\hline Bergen & 473 & Dubbeldam & 398 \\
\hline Hoorn & 467 & Sittard & 391 \\
\hline 's-Gravenzande & 466 & Didam & 391 \\
\hline $\operatorname{Delfz}\lfloor j 1$ & 464 & Oldenzaal & 390 \\
\hline Goes & 463 & Doesburg & 387 \\
\hline Hendrik Ido Ambacht & 457 & Coevorden & 387 \\
\hline Boxtel & 456 & Roermond & 385 \\
\hline Maasslu1s & 455 & Tubbergen & 384 \\
\hline Goor & 454 & Leerdam & 383 \\
\hline Wageningen & 452 & Leiderdorp & 382 \\
\hline Made en Drimmelen & 452 & Blaricum & 381 \\
\hline Spijkenisse & 452 & Sassenneim & 379 \\
\hline Zundert & 451 & Borne & 378 \\
\hline Heemskerk & 450 & IJsselstein & 370 \\
\hline Breda & 448 & Vianen & 366 \\
\hline Bunschoten & 448 & Cuyk en St. Agatha & 363 \\
\hline Veenendaal & 445 & U1tgeest & 384 \\
\hline Groenlo & 441 & Culemborg & 352 \\
\hline Zwijndrecht & 440 & Maasbracht & 349 \\
\hline Asten & 439 & Eigsden & 342 \\
\hline Bolsward & 438 & Geleen & 330 \\
\hline Krommente & 436 & Grootebroek & 325 \\
\hline Alme 10 & 435 & Broukelen & 323 \\
\hline Dinxperlo & 434 & Susteren & 297 \\
\hline Middelharnts & 431 & Eygelshoven & 272 \\
\hline Boskoop & 430 & Axel & 268 \\
\hline Sliedrecht & 429 & Swalmen & 265 \\
\hline
\end{tabular}


Tabel V-1:

Varlabelen betreffende de fyslek-morfologische kentnerken van de gemeenten;

spreidingsbreedte, centrale tendentie en verdeling over de hoofdurbenisatiecategorielin

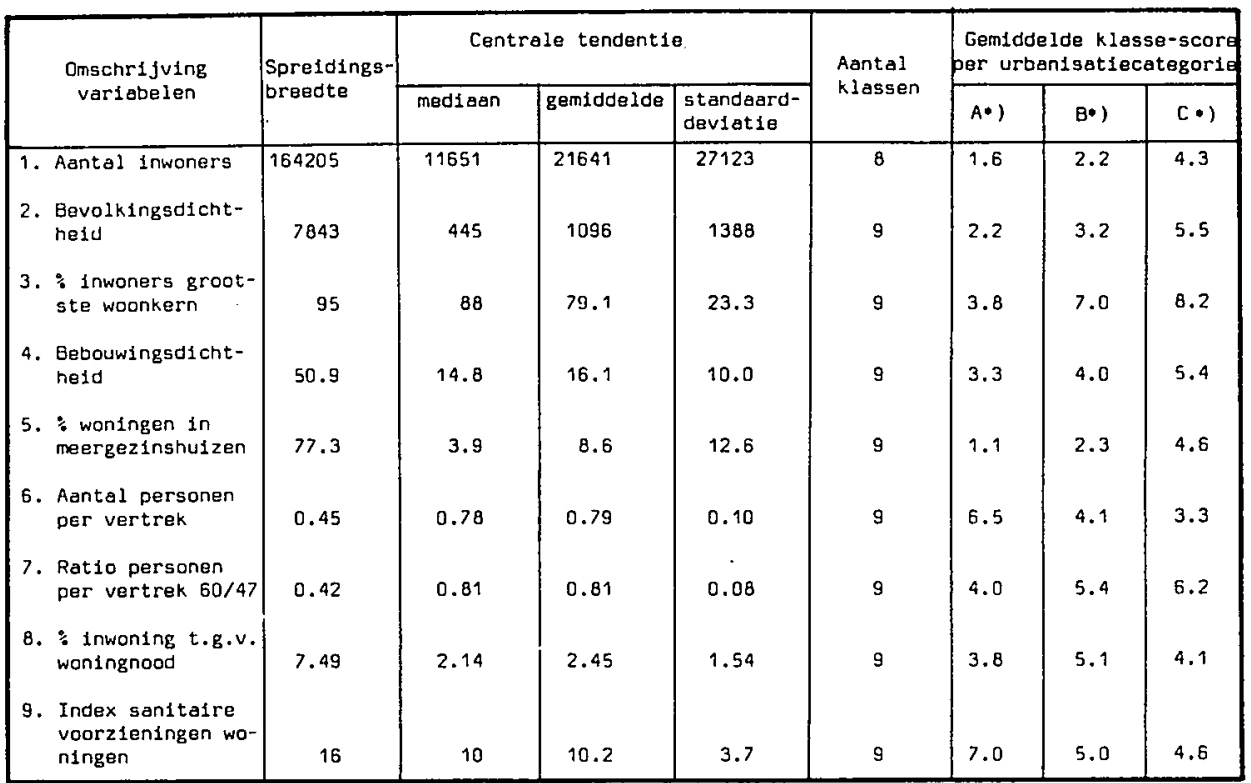

-) A, B en C staan voor respektievelijk de urbanisatie-categorieën plattelandsgemeenten ( $N=44)$, verstedelijkte plattelandsgemeenten $(N=62)$ en stedelijke gemeenten $(N=70)$.

Tabel $\mathrm{V}-2$ :

Variabelen betreffende de socio-economische elgenschappen van de gemeenten; spreidingsbreedte, centrale tendentie en verdeling over de hoofdurbanisatiecategorieën

\begin{tabular}{|c|c|c|c|c|c|c|c|c|}
\hline \multirow{2}{*}{$\begin{array}{l}\text { Omschrijuing } \\
\text { variabelen }\end{array}$} & \multirow{2}{*}{$\begin{array}{l}\text { Spreidings- } \\
\text { breedte }\end{array}$} & \multicolumn{3}{|c|}{ Centrale tendentie } & \multirow{2}{*}{$\begin{array}{l}\text { Aantal } \\
\text { klassen }\end{array}$} & \multicolumn{3}{|c|}{$\begin{array}{l}\text { Gemiddelde klasse-score } \\
\text { per urbanisatiecategorie }\end{array}$} \\
\hline & & mediaan & gemiddelde & $\begin{array}{l}\text { standaard- } \\
\text { deviatie }\end{array}$ & & A & 8 & C \\
\hline $\begin{array}{l}\text { 10. Index socio- } \\
\text { economisch niveau }\end{array}$ & 24 & 12 & 12.9 & 5.7 & 9 & 2.3 & 4.7 & 5.9 \\
\hline $\begin{array}{l}\text { 11. : land- en hand- } \\
\text { arbelders }\end{array}$ & 41.1 & 42. & 42.5 & 8.9 & 9 & 3.9 & 6.2 & 5.8 \\
\hline $\begin{array}{l}12 . \% \text { inwuners in } \\
\text { komen } \% f 5.000,-\end{array}$ & 63.7 & 54.0 & 53.5 & 7.3 & $S$ & 6.9 & 5.0 & 5.3 \\
\hline $\begin{array}{l}\text { 13. Inkomensdiscre- } \\
\text { pantie }\end{array}$ & 29.8 & 12.6 & 13.0 & 4.1 & 9 & $\left.5.1^{\circ}\right)$ & $5.5^{\circ}$ & $5.8^{* 1}$ \\
\hline $\begin{array}{l}\text { 14. Ratio inkomensdis } \\
\text { crepantie } 60 / 46\end{array}$ & 3.68 & 1.45 & 1.48 & 0.49 & 9 & 3.1 & 3.6 & 5.0 \\
\hline $\begin{array}{l}\text { 15. Rotio gemiddeld } \\
\text { inkornen } 60 / 46\end{array}$ & 2.75 & 2.99 & 3.04 & 0.41 & $S$ & 4.5 & 5.1 & 3.9 \\
\hline
\end{tabular}

- 'Deze variabele is gescoord van hoogste (score 1) naar leagste (score 9) waarde, dat wil zegfen van peringste naar grootste inkomensdiscrepantie - zle bijlage II. 
iave: $\vee-3$ :

W: Hatelen igtreffunde de elgenschappen van de economische struktuur van de gemeenten:

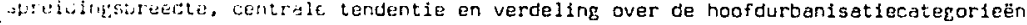

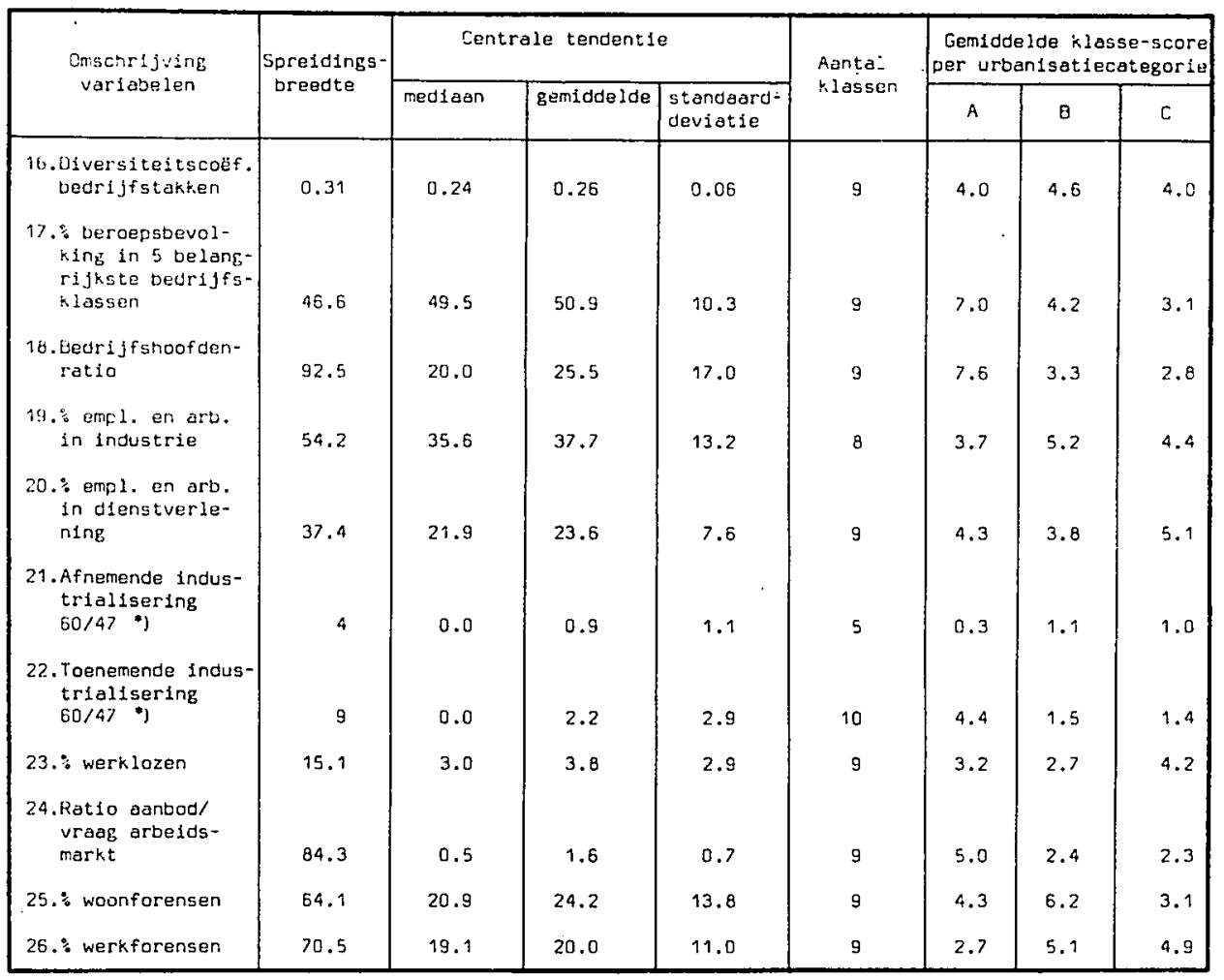

-) Gezien de berekeningswijze van deze variabeien (zie bijlage II) zijn hier de spreidingsbreedte en centrale tendentie van hun klassenindeling gegeven. 
Tabel $V-a$ :

Variabelen betreffende de socio-kulturele elgenschappen van de gemeenten;

spreidingstreedte, centrale tendentie en verdeling over de noofdurbanisatiecategorieęn

\begin{tabular}{|c|c|c|c|c|c|c|c|c|}
\hline \multirow{2}{*}{$\begin{array}{l}\text { Umschrijuing } \\
\text { variabelen }\end{array}$} & \multirow{2}{*}{$\begin{array}{l}\text { Spreidings- } \\
\text { breedte }\end{array}$} & \multicolumn{3}{|c|}{ Centrale tendentie } & \multirow{2}{*}{$\begin{array}{l}\text { Aantal } \\
\text { Klassen }\end{array}$} & \multicolumn{3}{|c|}{$\begin{array}{l}\text { Gemiddelde klasse-score } \\
\text { per urbanisatiecategorie }\end{array}$} \\
\hline & & mediean & gemiddelde & $\begin{array}{l}\text { stendoard- } \\
\text { deviatie }\end{array}$ & & A & 8 & C \\
\hline $\begin{array}{l}27 . \% \text { autochtone } \\
\text { bevolking }\end{array}$ & 63.0 & 56.0 & 56.6 & 12.3 & 9 & 6.3 & 4.1 & 3.8 \\
\hline $\begin{array}{l}\text { 28. In buitenland } \\
\text { geboren inwoners }\end{array}$ & 13.1 & 2.6 & 2.9 & 2.0 & 9 & 2.3 & 5.0 & 4.8 \\
\hline $\begin{array}{l}\text { 29. Ratio alloch- } \\
\text { tone bevolking } \\
60 / 47\end{array}$ & 1.22 & 1.11 & 1.15 & 0.17 & 10 & 2.1 & 3.0 & 2.3 \\
\hline $\begin{array}{l}\text { 30. Eevolkings- } \\
\text { groei }\end{array}$ & 99.9 & 22.8 & 27.0 & 19.5 & 9 & 3.0 & 5.1 & 4.4 \\
\hline $\begin{array}{l}\text { 31. Diversite1ts- } \\
\text { coéf. bevol- } \\
\text { k1ngsgroei }\end{array}$ & 0.30 & 0.10 & 0.12 & 0.04 & 8 & 2.0 & 2.6 & 2.1 \\
\hline $\begin{array}{l}\text { 32. Diversiteits- } \\
\text { coüf, sociale } \\
\text { beroepsgroepen }\end{array}$ & 0.28 & 0.22 & 0.23 & 0.05 & 9 & 4.3 & 4.5 & 3.8 \\
\hline $\begin{array}{l}\text { 33. Diversiteits- } \\
\text { calf. ultslag } \\
\text { verkiezingen }\end{array}$ & 0.75 & 0.26 & 0.37 & 0.21 & 9 & 4.4 & 4.7 & 3.4 \\
\hline $\begin{array}{l}\text { 34. Gemiddeld : } \\
\text { stemmen PvoA, } \\
\text { PSP, CPN }\end{array}$ & 63.5 & 28.4 & 29.5 & 15.9 & 9 & 3.2 & 4.1 & 5.6 \\
\hline $\begin{array}{l}\text { 35. O rooms-katho- } \\
\text { lieker: }\end{array}$ & 99.0 & 27.4 & 39.5 & 34.4 & 9 & 4.6 & 5.1 & 4.1 \\
\hline $\begin{array}{l}\text { 36. Secularisering } \\
60 / 47\end{array}$ & 9.66 & 1.17 & 1.45 & 1.16 & 10 & 2.4 & 3.1 & 1.9 \\
\hline
\end{tabular}

Tabel $V-5$

Variabelen betreffende de elgenschappen van de bevolking van de gemeenten:

spreidingsbreedte, centrale tendentie en verdeling over de hoofdurbanisatiecategorleën

\begin{tabular}{|c|c|c|c|c|c|c|c|c|}
\hline \multirow{2}{*}{$\begin{array}{l}\text { Onsehrijuing } \\
\text { variabelen }\end{array}$} & \multirow{2}{*}{$\begin{array}{c}\text { Spreldings } \\
\text { breedte }\end{array}$} & \multicolumn{3}{|c|}{ Centrale tendentie } & \multirow{2}{*}{$\begin{array}{l}\text { Rantal } \\
\text { klassen }\end{array}$} & \multicolumn{3}{|c|}{$\begin{array}{l}\text { Gemiddelde klasse-score } \\
\text { per urbanisatiecategorie }\end{array}$} \\
\hline & & mediaan & gemiddelde & $\begin{array}{l}\text { standaard- } \\
\text { deviatie }\end{array}$ & & $A$ & $\overline{\mathrm{C}}$ & $c$ \\
\hline $\begin{array}{l}37 \text { inworlers van } \\
\text { if } 49 \text { jaar }\end{array}$ & 9.7 & 46.1 & 46.1 & 1.8 & 9 & 4.3 & i. . i & 5.6 \\
\hline 3.B. jam.jenratio & 0.33 & 0.20 & 0.21 & 0.07 & 9 & 4.0 & 3.7 & $r .3$ \\
\hline 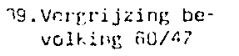 & 1.12 & 1.13 & 1.14 & 0.18 & 10 & 3.5 & 2.8 & 2.8 \\
\hline 40. aver-ratio & 0.36 & 0.58 & 0.99 & 0.116 & $\mathrm{~s}$ & $\therefore 5$ & $4.2^{2}$ & 5.6 \\
\hline $41 . \%$ nngertuwden & 26.5 & 18.2 & 19.3 & 4.6 & 9 & 5.3 & 4.4 & 3.3 \\
\hline $\begin{array}{l}42 . \approx \text { Lethud Eeweest } \\
\quad \therefore \text { indr. }\end{array}$ & 9.2 & 7.3 & 7.5 & 1.1 & 9 & $4, i t$ & 4.3 & $i . i$ \\
\hline
\end{tabular}


ialei V-ti:

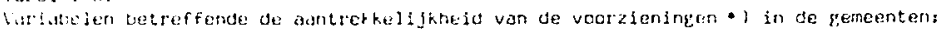

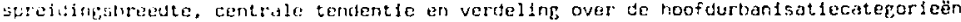

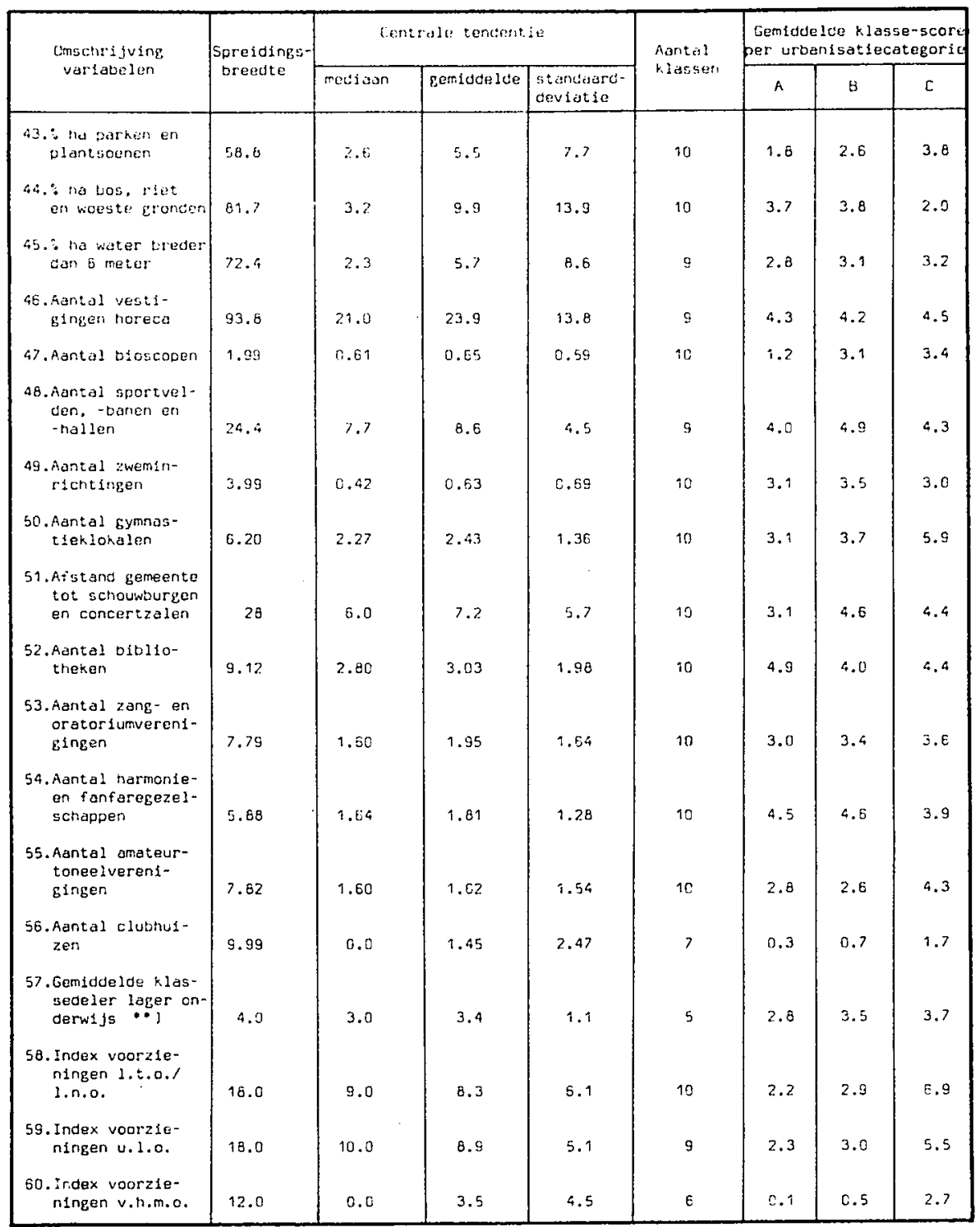

-) De politiesterkte en de med1sche voorzieningen werden reeds in tabel 4 ( 52.3 ) beschreven en zijn hier niet opnieuw opgenomen.

- - De spreioingsoreedte. centrale tendentiematen en gemidaelde klasse-score per urbanisatiecatezorie van deze variabele betreffen de klasse-indeling van de gemiddelde klassedeler zoals overgenomen van het C.S.S. te weten gemiddelde klassedeler <32.0 (score 1), 32.0 33.9 (score 2), $34.0-35.9$ (score 3), 36.0 - 37.9 (score 4) en gemiddelde $k$ lassedeler $>38.0$ (score 5 ). 
Resultaten orthogonale componenten-analyse. U1tgevaerd op 67 kenmeriken van 176 gemeenten: Principale componenten

\begin{tabular}{|c|c|c|c|c|c|c|c|}
\hline \multirow{2}{*}{ Gemeentekenmerken } & \multicolumn{7}{|c|}{ Principale componenten } \\
\hline & $F$ & FII & F III & F IV & $F_{V}$ & FVI & $n^{2}$ \\
\hline Index socio-economisch niveau & .88 & .13 & .14 & -.24 & .10 & -.08 & .89 \\
\hline Index sanitaire voorzieningen woningen & -.79 & -.33 & .07 & .23 & -.10 & .08 & .82 \\
\hline " autochtone bevolk1ng & -.73 & -.09 & .12 & .21 & -.40 & .10 & .78 \\
\hline Aantal parsanen per vertrek & -.85 & .02 & .09 & .05 & -.27 & .03 & .81 \\
\hline$\because$ Inwoners grootste woonkern & .80 & .25 & -.14 & .19 & .08 & -.05 & .77 \\
\hline Eedrijf shoofdenratio & -.65 & -.56 & .07 &.- .26 & -.04 & -.12 & .82 \\
\hline$\because$ in buitenland geboren inwoners & .55 & .32 & .31 & -.17 & .18 & -.01 & .56 \\
\hline $\begin{array}{l}\text { beroepsbevolking in } 5 \text { belangrijkste } \\
\text { bedriffsklassen }\end{array}$ & -.75 & -.08 & -.09 & -.04 & -.18 & .07 & .61 \\
\hline : werkforensen & .49 & .49 & -.07 & -.01 & .30 & .12 & .59 \\
\hline Sexe ratio $(V / M)$ & .75 & -.10 & .34 & -.08 & .10 & .01 & .70 \\
\hline Ratio personen per vertrek $60 / 47$ & .66 & -.01 & .20 & -.08 & -.02 & .42 & .65 \\
\hline Hul sartsendichtheid & .65 & -.17 & .17 & -.16 & .27 & .04 & .58 \\
\hline Ratio aenbod/vraag arbeldsmarkt & -.41 & -.45 & -.04 & -.00 & -.23 & -.25 & .49 \\
\hline : Inwoners inkomen < f 5.000.- & -.50 & -.39 & .42 & .33 & -.07 & .20 & .73 \\
\hline Eevolkingsdichtheid & .70 & .13 & -.03 & .17 & -.31 & .01 & .63 \\
\hline *woningen in meergezinswoningen & .70 & .13 & -.09 & .12 & -.32 & -.11 & .64 \\
\hline Toenemende industrialisering $60 / 47$ & -.46 & -.29 & -.09 & -.03 & .16 & -.31 & .43 \\
\hline Afstand geneente tot schouwburgen en concertzalen & .47 & .32 & -.03 & -.29 & -.37 & .13 & .56 \\
\hline Inkomensdiscrepant 1e & .47 & -.14 & .34 & -.27 & .06 & .04 & .44 \\
\hline Afnemende Industrialisering $60 / 47$ & .45 & .28 & -.09 & -.19 & -.26 & .08 & .40 \\
\hline Aantal inwoners & .65 & .13 & .19 & .16 & -.52 & -.06 & .78 \\
\hline : inwoning tengevolge van wonlngnood & .21 & .39 & .37 & -.37 & -.20 & .09 & .52 \\
\hline "ho parken en plantsoenen & .45 & .04 & .04 & .04 & -.13 & -.19 & .26 \\
\hline Bejaardenratio & .47 & -.66 & -.08 & -.23 & .05 & .22 & .77 \\
\hline genuwd geweest zijnden & .60 & -.57 & .08 & -.22 & -.02 & .19 & .78 \\
\hline E bevolkingsgroei & .08 & .70 & -.04 & -.00 & .22 & -.29 & .63 \\
\hline Rat10 * allochtone bevolk1ng $60 / 47$ & -.25 & .39 & -.38 & .15 & .13 & -.34 & .52 \\
\hline * Inwoners van $14-49$ jaar & .01 & .72 & -.14 & .07 & -.04 & -.15 & .57 \\
\hline Secularisering $60 / 47$ & -.18 & .44 & -.08 & -.20 & .15 & -.37 & .43 \\
\hline Vergrijzing bevolking $60 / 47$ & .21 & -.32 & -.03 & -.30 & -.25 & .22 & .35 \\
\hline * land- en nandarbetiders & -.04 & .50 & -.37 & .54 & .06 & .19 & .72 \\
\hline O1versite1tscoüflciënt uitslag verkiezingen & -.45 & .44 & .52 & .31 & .02 & -.10 & .77 \\
\hline $\begin{array}{l}\text { Afstand gemeente tot dichtstbijzijnde } \\
\text { psychiatrische inrichting }\end{array}$ & .16 & .57 & -.01 & -.18 & .01 & -.18 & .42 \\
\hline Gemiddelde klassedeler lager onderwijs & .26 & .39 & .00 & .31 & .01 & -.10 & .33 \\
\hline Aantal amateurtoneelverenigingen & .28 & -.25 & .13 & .12 & .23 & .21 & .27 \\
\hline : Rooms-Kathol leken & -.30 & .46 & .68 & .18 & .04 & -.04 & .80 \\
\hline *ongehuwden & -.44 & .06 & .74 & .07 & -.05 & .04 & .75 \\
\hline Gems ddeld : stemnen PvdA, PSP, CPN & .57 & -.25 & -.56 & .04 & -.03 & .21 & .74 \\
\hline Aantal vestigingen horeca & -.11 & -.07 & .61 & .17 & .26 & -.10 & .50 \\
\hline Aental bibllotheken & -.00 & -.48 & -.48 & -.02 & .33 & -.09 & .58 \\
\hline Aartal zang- en oratoriumverenigingen & .06 & -.20 &. .51 & .05 & .19 & .07 & .35 \\
\hline : ha bos. rlet en woeste gronden & -.21 & .11 & .49 & -.35 & -.02 & .19 & .46 \\
\hline * water breder dan 6 meter & .20 & .01 & $\because 50$ & .00 & .02 & -.06 & .29 \\
\hline Aantal sportvelden, -banen en -iallen & .04 & .10 & .42 & -.07 & .35 & .19 & .35 \\
\hline Index voorzieningen $1 . t, 0 . / 1 \cdot n \cdot 0$. & .49 & -.14 & .15 & .63 & -.04 & -.00 & .59 \\
\hline Index voorzieningen U.L.O. & .49 & -.15 & .17 & .55 & .14 & -.06 & .61 \\
\hline : woonforensen & -.21 & .52 & -.09 & -.45 & .23 & .05 & .59 \\
\hline Index voorzieningen v.h.m.o. & .59 & -.15 & .27 & .40 & -.07 & -.15 & .62 \\
\hline werklozen & .10 & -.37 & .16 & .47 & -.13 & -.27 & .48 \\
\hline Aental gyminastleklokalen & .57 & -.23 & -.02 & .34 & .08 & .06 & .53 \\
\hline Ratio gamiddeld inkomen $60 / 46$ & -.24 & .33 & .12 & -.30 & .13 & .18 & .32 \\
\hline Rat 10 inkomensdiscrepantie $60 / 46$ & .29 & -.11 & -.03 & .35 & .08 & -.13 & .27 \\
\hline Aantal uloscopen & .11 & .05 & .24 & .40 & .53 & .13 & .58 \\
\hline Aantal zweminrichtingen & -.06 & -.81 & -.06 & .13 & .45 & .15 & .26 \\
\hline Aantal hamonie- en fanfaregezelschappen & -.32 & -.08 & -.25 & -.02 & .40 & .08 & .34 \\
\hline Bebouwingsdichtheid & .62 & .03 & -.21 & .11 & -.35 & -.15 & .50 \\
\hline Vroedvrouwen & -.01 & -.04 & .11 & -.15 & .36 & .22 & .21 \\
\hline Diversiteitscoefficiënt bevolkingsqroel & -.04 & -.02 & -.27 & -.03 & .35 & .96 & $.2 ?$ \\
\hline *mployés en arbeiders in industrie & -.22 & .52 & -.11 & .33 & .05 & .49 & .69 \\
\hline Divers1teıtscoëffıclënt bedrłjfstakken &. .13 & .40 & .00 & .06 & -.18 & .55 & .51 \\
\hline Diversiteitscoëfficiënt sociale beroepsgroepen & -.38 & .38 & -.30 & .20 & -.36 & .33 & .68 \\
\hline employé's en arbeiders in dienstverlening & .48 & -.42 & .47 & -.23 & -.03 & -.29 & .70 \\
\hline Politiesterkte & .04 & .08 & .02 & .25 & .05 & .36 & .21 \\
\hline Beschikbare zlekenhuisbeddagen & -.12 & .05 & .04 & .09 & .04 & -.10 & .144 \\
\hline W1 jkverpleegsters & .06 & $\because 01$ & .02 & -.10 & -.15 & -.018 & .04 \\
\hline Iandartsendichtheid & .14 & .17 & .08 & $-.3 f_{3}$ & -.06 & -.02 & .18 \\
\hline nantal clubhuizen & .36 & -.04 & -.01 & .18 & +.20 & .14 & .22 \\
\hline Eigenwaarden & 13.44 & 7.00 & 5.09 & 4.19 & $3 . .94$ & $\therefore \times 5$ & \\
\hline
\end{tabular}


Bijlage VII - 1

RANGORDENING GEMEENTEN VAN HOGE NAAR LAGE FACTORSCORES, INGEDEELD IN KWARTIELEN

Scores factor I: Welstand - stedelijkheid per gemeente.

\begin{tabular}{|c|c|c|c|}
\hline \multicolumn{2}{|c|}{ Vierde kwartiel (728-573) } & \multicolumn{2}{|c|}{ Derde kwartiel $(572-512)$} \\
\hline Gemeenten & Sctiras & Gemeenten & Scores \\
\hline Heenstede & $7 ? 8$ & Zaandam & 572 \\
\hline Naarden & 716 & Delft & 572 \\
\hline Blaricum & 708 & 's-Hertogenbosch & 572 \\
\hline Bussum .. & 705 & Landsmeer & 571 \\
\hline Voorburg & 690 & Waalwijk & 569 \\
\hline Diemen & 681 & Lochem & 568 \\
\hline Laren (NH) & 680 & Eygelshoven & 568 \\
\hline Le1derdorp & 674 & Leiden & 566 \\
\hline Zandvoort & 673 & Gouda & 562 \\
\hline Driebergen/R1jsenburg & 671 & Goes & 561 \\
\hline Hilversum & 670 & Middelburg & 557 \\
\hline Baarn & 649 & Schagen & 554 \\
\hline Waalre & 629 & Valkenswaerd & 553 \\
\hline Koog aan de Zaan & 617 & Breukelen & 552 \\
\hline Bergen & 613 & Zwolle & 551 \\
\hline Weesp & 610 & O1sterwijk & 551 \\
\hline Haarlem & 608 & Harderwigk & 549 \\
\hline Amnem & 607 & Almelo & 548 \\
\hline Purmerend & 605 & Vlissingen & 548 \\
\hline Roermond & 605 & Boskaop & 546 \\
\hline Gorinchem & 602 & Krimpen aan de IJssel & 546 \\
\hline Sp1jkenisse & 601 & Helmond & 545 \\
\hline Breda & 600 & Zoetermeer & 543 \\
\hline Sittard & 594 & Maassluis & 542 \\
\hline vlaardingen & 592 & Groningen & 541 \\
\hline Krommen1e & 590 & Assen & 540 \\
\hline Alkmaar & 589 & Hoorn & 540 \\
\hline Wageningen & 587 & Waddinxveen & 536 \\
\hline Zal tbommel & 587 & H\$1l egom & 533 \\
\hline Heer & 585 & Golrle & 532 \\
\hline Geleen & 584 & Oldenzaal & 530 \\
\hline Zutphen & 583 & Hendrik Ido Ambacht & 529 \\
\hline Schoonhoven & 580 & Appingedam & 527 \\
\hline Hengelo (0) & 579 & Meppel & 527 \\
\hline Wormerveer & 579 & Velonoven & 527 \\
\hline Dordrecht & 579 & Groenlo & 526 \\
\hline Deventer & 576 & Oss & 525 \\
\hline Maerssen & 576 & Dostzaan & 523 \\
\hline Sassenhelm & 576 & Son en Breugel & 523 \\
\hline Zw1jndrecht & 578 & Lesuwarden & 518 \\
\hline Hulst & 575 & Hat tem & 517 \\
\hline Goor & 574 & Brunssum & 517 \\
\hline Doesburg & 573 & UItgeest & 516 \\
\hline & & Culemborg & 514 \\
\hline & & Winschoten & 512 \\
\hline
\end{tabular}


Resultaten orthogonale componenten-analyse, uitgovoerd op 67 kenmerken van 476 Nederlandse Eemeenten: Varimax rotatie

\begin{tabular}{|c|c|c|c|c|c|c|c|}
\hline \multirow{2}{*}{ Gemeentekenmerken } & \multicolumn{7}{|c|}{ Varimax rotatí } \\
\hline & $\mathrm{F}_{\mathrm{I}}$ & FII & FIII & FIV & $\mathrm{F}_{\mathrm{V}}$ & FVI & $h^{2}$ \\
\hline Index socto-economisch niveau & .88 & .15 & -.04 & .10 & .17 & -.22 & .89 \\
\hline Index sanitaire vaorzieningen woningen & -.86 & .06 & .19 & .01 & -.18 & .08 & .82 \\
\hline autochtone bevolking & -.79 & -.02 & .28 & -.04 & .15 & .24 & .78 \\
\hline Aantal personen per vertrek & -.79 & -.16 & .29 & -.25 & .07 & .15 & .81 \\
\hline : Inwoners grootste woonkern & .74 & -.10 & -.25 & .36 & .11 & .09 & .76 \\
\hline Bedrijfshoofdenratio & -.73 & .25 & .08 & -.23 & $\therefore .12$ & -.40 & .83 \\
\hline : in buitenland geboren inworers & .71 & -.03 & .23 & -.02 & .04 & -.06 & .56 \\
\hline $\begin{array}{l}\text { beroepsuevolking in } 5 \text { belangrijkste } \\
\text { bedrijfsklassen }\end{array}$ & -.71 & -.06 & .07 & -.29 & -.01 & .11 & .61 \\
\hline : werkforensen & .69 & -.21 & -.08 & -.04 & $=.12$ & .22 & .59 \\
\hline Sexe ratio (V/M) & .68 & .32 & .13 & .26 & .06 & -.21 & .70 \\
\hline Ratio personen per vertrek $60 / 47$ & .61 & .47 & .05 & .10 & $.0 \theta$ & .20 & .65 \\
\hline Huisartsendichtheid & .61 & .33 & -.03 & .14 & -.13 & -.24 & .58 \\
\hline Ratio aanbod/uraag arbeldsmarkt & -.60 & .10 & -.04 & .06 & .10 & -.31 & .48 \\
\hline$\because$ inwoners inkomen $<f 5.000,-$ & -.59 & .28 & .46 & .23 & -.20 & .09 & .73 \\
\hline Bevolkingsdichtheld & .53 & .08 & -.14 & .37 & .42 & .13 & .63 \\
\hline * woningen in meergezinshulzen & .51 & .02 & -.20 & .35 & .46 & .04 & .64 \\
\hline Toenemende industrialisaring $60 / 47$ & -.48 & -.12 & -.06 & -.05 & -.23 & -.35 & .43 \\
\hline Afstand gemeente tot schouwburgen en concertzalen & .48 & .09 & -.07 & -.18 & .51 & .15 & .56 \\
\hline Inkomens di screpantie & .47 & .36 & .17 & .01 & .04 & -.25 & .44 \\
\hline Afnemende Industrialisering $50 / 47$ & .45 & .04 & -.14 & -.09 & .40 & .13 & .40 \\
\hline Aantal inwoners & .44 & .11 & .08 & .40 & .62 & .08 & .78 \\
\hline : inwoning tengevalge van woningnood & .39 & .03 & .37 & -.32 & .34 & .04 & .51 \\
\hline : ha parken en plantscenen & .34 & -.01 & -.05 & .24 & .25 & -.13 & .26 \\
\hline Bejaardenrat io & .20 & .74 & -.32 & .12 &. .07 & -.25 & .77 \\
\hline * gehuwd geweest zijnden & .34 & .72 & -.18 & .19 & .04 & -.26 & .78 \\
\hline : bevolkingsgroei & .38 & -.67 & .07 & $\therefore 15$ & -.01 & .05 & .63 \\
\hline Rat10 allochtone bevolking $60 / 47$ & -.12 & -.66 & -.23 & -.07 & -.07 & .03 & .52 \\
\hline * Inwoners van $14-49$ Jaar & .24 & -.62 & .01 & $\therefore .15$ & .18 & .26 & .56 \\
\hline Secularisering $60 / 47$ & .07 & -.55 & .03 & -.31 & $\therefore .00$ & -.17 & .43 \\
\hline Vergrijzing bevolking & .05 & .51 & -.14 & -.11 & .22 & -.06 & .35 \\
\hline$\because$ land- en handarbeiders & .04 & -.47 & -.20 & .19 & -.11 & .64 & .72 \\
\hline Diversiteltscoëfficiënt uitslag verkiezingen & -.20 & -.45 & .70 & .03 & -.06 & .19 & .77 \\
\hline $\begin{array}{l}\text { Afstand gemeente tot dichtstbijzijnde } \\
\text { psychiatrische inrichting }\end{array}$ & .38 & -.42 & .06 & -.24 & .18 & .03 & .42 \\
\hline Gemiddelde klassedeler lager onderwijs & .31 & -.35 & .04 & .25 & .08 & .20 & .33 \\
\hline Aental amateurtoneelverenlgingen & .21 & .32 & .02 & .24 & $\therefore .26$ & .01 & .27 \\
\hline : Rooms-Katholieken & -.01 & -.33 & .82 & -.02 & -.04 & .15 & .80 \\
\hline : ongehuwden & -.28 & .01 & .82 & -.05 & -.04 & .01 & .75 \\
\hline Gemiddeld : stemmen PudA, PSP, CPN & .31 & .31 &. .69 & .22 & .05 & .11 & .74 \\
\hline Aantal vestigingen horeca & -.01 & -.00 & .60 & .19 & -.28 & -.18 & .50 \\
\hline Aantal bibliotheken & -.15 & .24 & $=.56$ & .04 & -.40 &. .13 & .58 \\
\hline Aantal zang- en oratorfumverenigingen & -.05 & .05 & -.54 & .04 & -.22 & .03 & .34 \\
\hline$\because$ ha bos, riet en waeste gronden & .00 & .17 & .52 & -.39 & .01 & -.01 & .46 \\
\hline * ha water breder dan 6 meter & .11 & -.09 & -.52 & .03 & .03 & .03 & .29 \\
\hline Aantal sportvelden, -banen en -hallen & .25 & .10 & .41 &. .10 & -.32 & .03 & .35 \\
\hline Index voorziensingen $1 . t, 0 . / 1 . n .0$. & .25 & .10 & .05 & .77 & .01 & .13 & .69 \\
\hline Index voorzieningen U.L.O. & .31 & .06 & .05 & .70 & -.13 & .02 & .69 \\
\hline woonforensen & .16 & -.32 & .03 & -.66 & -.19 & .08 & .59 \\
\hline Index voorzientingen v.h.m.o. & .36 & .12 & .12 & .66 & .12 & -.10 & .62 \\
\hline werklozen & -.18 & .06 & .08 & .63 & .06 & $\therefore 19$ & .48 \\
\hline Aantal gynnastleklokalen & .33 & .27 &. .18 & .56 & -.07 & .00 & .53 \\
\hline Ratio gemiddeld inkomen $60 / 46$ & .04 & -.10 & .22 & -.48 & -.10 & .13 & .32 \\
\hline Ratio inkomensdiscrepant1e $60 / 46$ & .15 & -.06 & -.10 & .47 & -.05 & -.07 & .27 \\
\hline Aantal biascopen & .22 & -.09 & .23 & .36 & -.55 & .17 & .58 \\
\hline Aantal zweminrichtingen & .01 & .04 & -.08 & .05 & -.50 & .05 & .26 \\
\hline Aantal hormonie- en fanfaregezelschappen & -.22 & -.09 &. .19 & -.15 & -.48 & .03 & .34 \\
\hline Bebouwingsdichthe1d & .38 & .03 & -.32 & .34 & .47 & -.01 & .59 \\
\hline Vroedvrouwen & .13 & .15 & .09 & -.18 & -.36 & .00 & .21 \\
\hline Diversiteltscoëfflelënt bevolkingsgraei & .02 & -.19 & -.26 & -.06 & -.30 & -.15 & .22 \\
\hline employé's en arbeiders in Industrie & -.02 & -.24 & .09 & -.09 & -.17 & .77 & .69 \\
\hline Diversiteitscoëfficiënt bedrijfstakken & .01 & .02 & .14 & -.23 & .08 & .66 & .51 \\
\hline Diversiteitscoëfficlënt soclale beroepsgroepen &. .33 & -.21 & -.10 & -.17 & $.2 ?$ & .65 & .56 \\
\hline * emoloyés en arbeiders in dienstverlening & .32 & .39 & .23 & .24 & .16 & -.61 & .76 \\
\hline Polltlesterkte & .06 & .09 & .05 & .12 & -.15 & .39 & .21 \\
\hline Beschikbare ziekenhulsbeddogen & -.00 & .15 & .08 & .04 & -.05 & -.02 & .04 \\
\hline W1 Jkverpleegsters & .02 & .03 & -.01 & -.03 & .18 & -.09 & .04 \\
\hline Tandart sendichtheid & .24 & .02 & .06 & -.29 & .17 & -.10 & .18 \\
\hline Aantal clubhuizen & .21 & .18 & -.07 & .27 & .18 & .17 & $.7 ?$ \\
\hline Eigenwaorden & 11.18 & 5.52 & 5.55 & 5.57 & 3.77 & 3.9 .3 & \\
\hline
\end{tabular}


'scores fuctor I: Welstifl - stefel Ijkheid per pemeente

\begin{tabular}{|c|c|c|c|}
\hline \multicolumn{2}{|c|}{ Iwerede kwartiel (509-439) } & \multicolumn{2}{|c|}{ Eerste fwartied $(438-275)$} \\
\hline Gemeenten & scores & Gemeenten & Scores \\
\hline Veinendasl & 509 & Neede & 938 \\
\hline Assondelft & 509 & OIst & 436 \\
\hline Vianen & 509 & R1)533n & 433 \\
\hline Alphen aan de Rijn & 508 & Elsloo & 4.31 \\
\hline Veghel & 508 & Langedijk & 430 \\
\hline Heeze & 506 & Rijnsburg & 429 \\
\hline Dokkum & 503 & Klundert & 420 \\
\hline Cuyk en St. Agatha & 500 & Barculo & 425 \\
\hline Geldermalsen & 499 & Made en Drimmelen & 419 \\
\hline Swalmen & 499 & Denekamp & 994 \\
\hline Steenwijk & 497 & Dude Pekela & 407 \\
\hline Boxtel & 497 & Vinkeveen en Waverveen & 402 \\
\hline Sneek & 495 & 's-Gravendeel & 400 \\
\hline Middelharnis & 495 & Hulsgen & 397 \\
\hline Coevorden & 489 & N1euwe Pekela & 394 \\
\hline Berzeyk & 489 & Asten & 390 \\
\hline Eijsden & 487 & Holten & 331 \\
\hline Dedfzijl & 486 & Strijen & 379 \\
\hline Heenskerk & 485 & E1bergen & 377 \\
\hline Zlerikzee & 485 & Bunschoten & 376 \\
\hline IJsselstein & 484 & Heesch & 376 \\
\hline Dubbeldam & 483 & Didam & 363 \\
\hline Eelde & 480 & Zundert & 358 \\
\hline Oud-Belferland & 480 & Wisthe & 347 \\
\hline Oost- en West-Soubure & 479 & Duiven & 347 \\
\hline Eolsward & 477 & Amst Delden & 345 \\
\hline Leerdam & 475 & Smllde & 345 \\
\hline Sliedrecht & 473 & Grootebroek & 336 \\
\hline Borne & 472 & Heerhugowaard & 335 \\
\hline Mausbracht & 471 & Laren $(G)$ & 334 \\
\hline Harlingen & 468 & Pelien & 332 \\
\hline Susteren & 461 & Lemsterland & 331 \\
\hline Dinxperio & 460 & Maasdriel & 321 \\
\hline Hoogkerk & 457 & Hengelo (G) & 310 \\
\hline Eersel & 457 & Ommen & 317 \\
\hline Enkhuizen & 455 & Weerselo & 317 \\
\hline Schijndel & 450 & Ruurlo & 313 \\
\hline Hardinxveld/Giessendan & 447 & Dalf $38 n$ & 301 \\
\hline Kampen & 446 & Tubbergen & 298 \\
\hline Vorden & 446 & Staphorst & 297 \\
\hline HIlvarenbeek & 442 & Zel hem & 295 \\
\hline 's-Gravenzande & 440 & Urk & 293 \\
\hline De Lier & 439 & Markelo & 287 \\
\hline Axe1 & 439 & ZuIdwolde & 275 \\
\hline
\end{tabular}


Bijlage VII - 3

Scores factor II: Stagnerende groel - vergrljzing

\begin{tabular}{|c|c|c|c|}
\hline \multicolumn{2}{|c|}{ Vierde kwartiel (695-573) } & \multicolumn{2}{|c|}{ Derde kwartiel (572-506) } \\
\hline Gemeenten & Scores & Gemeénten & Scores \\
\hline Heemstede & 695 & Hengelo $(0)$ & 572 \\
\hline Markelo & 686 & Deventer & 570 \\
\hline Bergen & 684 & Hoorn & 569 \\
\hline Koog aan de Zaan & 675 & Arnhem & 568 \\
\hline Driebergan/Rijsenburg & 674 & Nieuwe Pekela & 568 \\
\hline Bearn & 674 & Lemsterland & 567 \\
\hline Olst & 673 & Assendelft & 564 \\
\hline Laren $\{G\}$ & 672 & Krommenis & 563 \\
\hline Hilversum & 662 & Stephorst & 562 \\
\hline Blaricum & 659 & Uitgeest & 561 \\
\hline Bussum & 658 & Denskamp & 557 \\
\hline Laren $(\mathrm{NH})$ & 644 & Zwolle & 556 \\
\hline Vorden & 644 & Heerhugowaard & 556 \\
\hline Zuldwolde & 640 & Horlingen & 555 \\
\hline Lochem & 636 & Zlerikzee & 553 \\
\hline Neede & 631 & Sneek & 551 \\
\hline Haarlem & 630 & Rijssen & 551 \\
\hline Wijhe & 617 & $\mathrm{Hu} 1 \mathrm{st}$ & 549 \\
\hline Weerse 10 & 615 & Boskoop & 546 \\
\hline Zelhem & 611 & Gouda & 545 \\
\hline Middelburg & 610 & Borne & 544 \\
\hline Hengelo (G) & 606 & Beilen & 544 \\
\hline Ruurlo & 603 & Wageningen & 543 \\
\hline Naarden & 601 & Dinxper10 & 542 \\
\hline Groningen & 598 & Goes & 541 \\
\hline Schagen & 594 & Wormerveer & 540 \\
\hline Zaandam & 588 & Leerdam & 540 \\
\hline Leeuwarden & 586 & Langedijk & 540 \\
\hline Borculo & 586 & Sin1lde & 537 \\
\hline Elbergen & 583 & Delft & 530 \\
\hline Zutphen & 582 & Meppel & 529 \\
\hline Winschoten & 582 & Zal tbamnel & 528 \\
\hline Zandvoort & 580 & Almelo & 528 \\
\hline Leiden & 580 & Doesburg & 525 \\
\hline Ommen & 580 & Ambt Delden & 525 \\
\hline Voorburg & 579 & H1 lvarenbeek & 523 \\
\hline Goor & 579 & Dordrecht & 522 \\
\hline Culemborg & 576 & Strijen & 522 \\
\hline Bolsward & 575 & Tubbergen & 521 \\
\hline Delfsen. & 575 & Goirle & 520 \\
\hline Alkmaar & 574 & Groenlo & 517 \\
\hline Enkhulzen & 574 & Alphen aan de Rijn & 511 \\
\hline Assen & 573 & 's-Gravenzande & 508 \\
\hline Holten & 573 & Coevoerden & 506 \\
\hline
\end{tabular}


Scores factor II: Stagnerende groel - vergr1jzing

\begin{tabular}{|c|c|c|c|}
\hline \multicolumn{2}{|c|}{ Tweede kwart1el (505-443) } & \multicolumn{2}{|c|}{ Eerste kwartiel $(441-182)$} \\
\hline Gemeenten & Scores & Gemeenten & Scores \\
\hline IJsselstein & 505 & Rijnsburg & 441 \\
\hline Hillegern & 504 & Dost- en West-Souburg & 436 \\
\hline Bredú & 503 & harderwi ik & 435 \\
\hline Dude Peksla & 502 & Waddinxveen & 434 \\
\hline Hardinxveld/Glessendem & 501 & Veghel & 433 \\
\hline Oisterwijk & 499 & Diemen & 432 \\
\hline Appingedarn & 498 & $A \times B 1$ & 432 \\
\hline Vinkeveen en Waverveen & 498 & E1jsden & 431 \\
\hline Dokkum & 497 & Zundert & 429 \\
\hline Middelharnis & 497 & Susteren & 425 \\
\hline Hoogkerk & 497 & Valkensweard & 421 \\
\hline Geldermalsen & 493 & Bergeyk & 421 \\
\hline Asten & 491 & Heaze & 416 \\
\hline De Lier & 489 & Hu1ssen & 415 \\
\hline Steenw1jk & 483 & 's-Hertogenbosch & 409 \\
\hline Hat tem & 480 & Woolre & 402 \\
\hline Breukelen & 479 & Woolwijk & 400 \\
\hline Vienen & 479 & Maesdr1el & 400 \\
\hline Grootebroek & 477 & Eersel & 395 \\
\hline Kempen & 476 & Roermond & 393 \\
\hline Oud Befjerlend & 475 & Bunschoten & 388 \\
\hline V1issingen & 474 & Urk & 385 \\
\hline Gorinchem & 470 & Krimpen aan de IJssel & 383 \\
\hline Schoonhoven & 470 & Made en Drimmelon & 379 \\
\hline Eelde & 470 & Veenendael & 376 \\
\hline Sassenthe Im & 466 & E1Jgelshoven & 371 \\
\hline Sliedrecht & 466 & Cuyk on St. Agatha & 368 \\
\hline Oostzaan & 464 & Landsmeer & 359 \\
\hline Weesp & 462 & Zwifndracht & 357 \\
\hline Maarssen & 462 & Oss & 356 \\
\hline Dubbeldan & 462 & Vlaaraingen & 352 \\
\hline Duiven & 461 & Delfzifl & 345 \\
\hline Schifndel & 459 & Lefderdorp & 342 \\
\hline Brunssum & 454 & Son en Breugel & 332 \\
\hline 's-Gravendee l & 454 & Geleen & 324 \\
\hline Swalmen & 453 & Zoetermeer & 322 \\
\hline Heet & 451 & Heesch & 302 \\
\hline Purmerend & 450 & Sittard & 277 \\
\hline Eoxte 1 & 450 & Hendrik Ido Ambacht & 275 \\
\hline Helmond & 448 & Elsloo & 257 \\
\hline Maossluis & 446 & Veldhoven & 247 \\
\hline Didam & 446 & Maasbracht & 244 \\
\hline Oldenzaol & 445 & Heemskark & 236 \\
\hline Klundert & 443 & Spljkenlsse & 182 \\
\hline
\end{tabular}


Scores factor III: Godsdienst per gemeente

\begin{tabular}{|c|c|c|c|}
\hline \multicolumn{2}{|c|}{ V1erde kwartiel $(723-559)$} & \multicolumn{2}{|c|}{ Derde kwartiel $(565-486)$} \\
\hline Geneenten & Scores & Gemeenten & Scores \\
\hline Bergeyk & 725 & Blaricum & 565 \\
\hline Hilvarenteek & 721 & Bussum & 560 \\
\hline O1sterwijk & 77 & Arnhem & 559 \\
\hline Vegtiel & 701 & Dinen & 554 \\
\hline Hulst & 700 & Eibergen & 551 \\
\hline Boxtel & 693 & Harderw1jk & 551 \\
\hline Denekamp & 6,91 & Baarn & 546 \\
\hline Zundert & 683 & Eijgelshoven & 546 \\
\hline Valkensward & 683 & Borne & 545 \\
\hline Heeze & 682 & Fêde en Drimmelen & 542 \\
\hline Asten & 681 & Wageningen & 540 \\
\hline Weerselo & 677 & IJsselstein & 539 \\
\hline Schijndel & 672 & 7andvoort & 538 \\
\hline Tubvergen & 669 & Maásbracht & 536 \\
\hline Goirle & 607 & Grootebroek & 535 \\
\hline Eersel & 654 & leiden & 533 \\
\hline E1jsden & 643 & Heerhugowaard & 532 \\
\hline Cuyk en St. Agatha & 643 & Naarden & 530 \\
\hline Walre & 640 & Delft. & 530 \\
\hline Groenlo & 639 & Vorden & 528 \\
\hline Didam & 537 & Geleen & 528 \\
\hline Roemond & 531 & Alkmaar & 525 \\
\hline Laren $(\mathrm{NH})$ & 628 & Holten & 521 \\
\hline Breda & 623 & Brunssum & 519 \\
\hline Wealwijk & 622 & Vinkeveen en waverveen & 518 \\
\hline Oss & 622 & Ha]fsen & 517 \\
\hline Oldenzăal & 615 & $01 s t$ & 516 \\
\hline Helmond & 610 & Rijssen & 516 \\
\hline Ambt Delden & 600 & Whe & 514 \\
\hline Drieberzen/Rij senburg & 606 & Convorden & 513 \\
\hline Duiven & 604 & Assen & 512 \\
\hline Heesch & 603 & Eeilen & 512 \\
\hline Simalmen & lini & Hengelo $(0)$ & 511 \\
\hline Huissen & 598 & Alme lo & 511 \\
\hline Susteren & 597 & Sassenheirn & 503 \\
\hline Son en Breugel & 595 & Lochem: & 502 \\
\hline Ecrgen & 593 & Schagen & 502 \\
\hline Heer & 593 & U1tgeest & 496 \\
\hline Maasdriei & 593 & reurlo & 495 \\
\hline Veldhoven & 506 & Sneek & 493 \\
\hline 's-Hertogentuosch & 530 & Els100 & 493 \\
\hline Hilversum & 570 & yoorburg & 489 \\
\hline Heemstede & 571 & Goes & 487 \\
\hline Sittard & $5 E 0$ & Hoorn & 486 \\
\hline & & Hill legom & 486 \\
\hline
\end{tabular}


Scores factor III: Godsdienst per gemeente

\begin{tabular}{|c|c|c|c|}
\hline \multicolumn{2}{|c|}{ Tweede kwart1el (485-431) } & \multicolumn{2}{|c|}{ Eerste kwart1el $(428-289)$} \\
\hline Gemeenten & Scores & Gemeenten & Scores \\
\hline Zoetermeer & 485 & Dinxperlo & 428 \\
\hline Staphorst & 484 & Kampen & 427 \\
\hline Zwolle & 484 & GorInchem & 427 \\
\hline Hearlem & 483 & Goor & 425 \\
\hline Culemborg & 483 & Axel & 424 \\
\hline Breukelen & 482 & Middelharnis & 423 \\
\hline Henge 10 (G) & 481 & Geldermalsen & 421 \\
\hline Groningen & 480 & Oud Be1jerland & 421 \\
\hline Bolsward & 479 & Hattem & 420 \\
\hline Doesburg & 478 & Zaendam & 419 \\
\hline Markelo & 476 & Assendelft & 418 \\
\hline Lenged1Jk & 474 & Vianen & 413 \\
\hline Borculo & 472 & 2elhem & 412 \\
\hline Boskoop & 466 & Urk & 412 \\
\hline R1jngburg & 466 & Weesp & 410 \\
\hline Oiemen & 466 & K18ndert & 409 \\
\hline Maerssen & 463 & Vlissingen & 401 \\
\hline Purmerend & 463 & Schoonhoven & 400 \\
\hline Leeuwerden & 462 & Herdinxveld/Giesgendem & 399 \\
\hline Zutphen & 460 & Leerdern & 397 \\
\hline Harlingen & 460 & Enkhu1zen & 395 \\
\hline M1ddelourg & 459 & Vleerdingen & 395 \\
\hline Eelde & 454 & Dude Pekela & 392 \\
\hline De Lier & 452 & ZwiJndracht & 391 \\
\hline Deventer & 451 & Applingedem & 389 \\
\hline Laiderdorp & 451 & 's-Grovenzende & 383 \\
\hline Z1er1kze日 & 450 & Nleuwe Pokela & 381 \\
\hline Bunschaten & 450 & Lemsterdend & 366 \\
\hline Meppe1 & 449 & Wormerveer & 359 \\
\hline Winschoten & 448 & Moessluis & 359 \\
\hline Heemskerk & 448 & Hoogkerk & 354 \\
\hline Zal tbommel & 446 & Dost- en West-Soubrug & 353 \\
\hline Laren (G) & 445 & Krommente & 351 \\
\hline Dokkum & 444 & S11edracht & 347 \\
\hline Gouda & 443 & Dubbeldatn & 342 \\
\hline Alphen aan de R1jn & 443 & Krimpen aen de IJssel & 335 \\
\hline $5 m 11 d e$ & 441 & Dolfzifl & 334 \\
\hline Veenendeal & 440 & Strijen & 333 \\
\hline Steenw1jk & 437 & Hendrik Ido Ambosht & 321 \\
\hline Nesde & 436 & Koog aan de Zaan & 313 \\
\hline WoddInxveen & 436 & Oostzaan & 308 \\
\hline Zuidwolde & 434 & 'a-Grovendeel & 308 \\
\hline Dordrecht & 431 & Sp1jkan1880 & 293 \\
\hline & & Lendsme日r & 289 \\
\hline
\end{tabular}


Bijlege VII - 7

Scores factor IV: Onderwijsfac1lite1ten per gemeente

\begin{tabular}{|c|c|c|c|}
\hline \multicolumn{2}{|c|}{ V1orde kwortiel $(742-580)$} & \multicolumn{2}{|c|}{ Derde kwartiel (573-495) } \\
\hline Gemeenten & Scores & Gemsenten & Scores \\
\hline Sneek & 742 & Dordrecht & 573 \\
\hline Dokkum & 724 & Oude Pakela & 573 \\
\hline Herlingen & 697 & Ijsselstaln & 558 \\
\hline Hulst & 892 & Axal & 567 \\
\hline Z1ar1kze日 & 685 & Leiden & 566 \\
\hline Middelburs & 680 & Brada & 564 \\
\hline Winschoten & 677 & Schoonhoven & 564 \\
\hline Steanw1jk & 676 & Purmerend & 560 \\
\hline Lesuwarden & 683 & O88 & 559 \\
\hline Hoorn & 660 & Culemborg & 559 \\
\hline Goes & 657 & Locham & 554 \\
\hline Kempen & 655 & Didam & 549 \\
\hline$D \theta 1 f z 1 j 1$ & 654 & Haerlem & 549 \\
\hline Lemeterland & 649 & Vernendeol & 543 \\
\hline Zwollo & 648 & $\sin 11 d \theta$ & 540 \\
\hline Bolsward & 647 & Delft & 536 \\
\hline Gron1ngen & 643 & Leerdem & 534 \\
\hline V1losingen & 638 & Zundert & 532 \\
\hline 's-Hertogenboseh & 836 & Veghel & 530 \\
\hline Schegen & 836 & Geleen & 529 \\
\hline Urk & 835 & Sch1Jndel & 528 \\
\hline Alkmear & 630 & Wageningen & 526 \\
\hline Meppal. & 629 & Zoandem & 526 \\
\hline Almelo & 623 & Niouwo Pokela & 526 \\
\hline Deventer & 623 & O1sterwijk & 521 \\
\hline Grootebrook & 622 & Cuyk on St. Agathe & 521 \\
\hline M1ddelnamis & 620 & Longed1jk & 520 \\
\hline Roemond & 618 & Alphen oon de R1jn & 518 \\
\hline Enkhuizen & 612 & Harderw1Jk & 516 \\
\hline Zutphen & 611 & Geldermelsen & 515 \\
\hline Boxte1 & 608 & Borne & 512 \\
\hline Coevorden & 608 & Heerhugoweserd & 511 \\
\hline Gorinchem & 601 & Goor & 510 \\
\hline Goude & 597 & Hengelo $(0)$ & 509 \\
\hline Groenlo & 596 & Maasdriol & 508 \\
\hline Kelmond & 596 & Masobracht & 507 \\
\hline Absen & 595 & Braukolen & 503 \\
\hline Oud Beijarland & 595 & R1jusen & 501 \\
\hline AppIngedam & 595 & Suateren & 500 \\
\hline Oldenzad & 584 & Vlaardingen & 498 \\
\hline Waelw1jk & 593 & sliedrecht & 497 \\
\hline Zal tbormel & 592 & Baslan & 498 \\
\hline S1ttard & 580 & Borculo & 496 \\
\hline Arnhem & 580 & Doesburg & 495 \\
\hline
\end{tabular}


Scores factor IV: Onderwijsfacllitelten per geneente

\begin{tabular}{|c|c|c|c|}
\hline \multicolumn{2}{|c|}{ Twesde kwart1el $(492-421)$} & \multicolumn{2}{|c|}{ Eerste kwartiel (419-257) } \\
\hline Gemeenten & Scores & Gemeenten & Scores \\
\hline Huissen & 492 & Heer & 419 \\
\hline H11legom & 492 & Maarssen & 419 \\
\hline Elbergen & 489 & Hoogkerk & 419 \\
\hline Tubbergen & 487 & Elsloo & 418 \\
\hline Brunssum & 487 & Waddinxveen & 418 \\
\hline H1 lvarenbeek & 482 & Hengelo (G) & 416 \\
\hline Exjsden & 482 & Bergeyk & 415 \\
\hline Made en Drimmelen & 482 & Hattem & 415 \\
\hline Asten & 480 & Vinkeveen en Waverveen & 414 \\
\hline Bunschoten & 479 & Baam & 413 \\
\hline Maassluis & 479 & Strijen & 413 \\
\hline Oost- en West-Soubrug & 478 & Weerselo & 412 \\
\hline Hilversum & 475 & 's-Gravenzande & 412 \\
\hline E1jgelshoven & 474 & Boskoop & 410 \\
\hline Swalmen & 473 & Vianen & 409 \\
\hline Spijkenisse & 473 & Heemskerk & 408 \\
\hline Weesp & 470 & Zelhem & 405 \\
\hline Bergen & 462 & U1tgeest & 404 \\
\hline Neede & 462 & Ruurlo & 403 \\
\hline Zwijndrecht & 462 & R1jusburg & 398 \\
\hline Zootermeer & 460 & Heeze & 397 \\
\hline Denekamp & 459 & Zuidwolde & 395 \\
\hline Ommen & 455 & Assendelft & 395 \\
\hline Eersel & 454 & Driebergen/R1jsenburg & 394 \\
\hline Duiven & 452 & Vorden & 391 \\
\hline Valkenswaerd & 451 & Olst & 387 \\
\hline Holten & 451 & Hendrik Ido Ambacht & 386 \\
\hline Goirle & 448 & Eelde & 383 \\
\hline Veldhoven & 448 & Delfsen & 380 \\
\hline Krimpen aan de IJssel & 448 & Markelo & 380 \\
\hline 's-Gravendeel & 447 & Dubbeldam & 373 \\
\hline Heesch & 446 & Zandvoort & 365 \\
\hline Krommenie & 446 & De Lier & 364 \\
\hline Klundert & 444 & Heenstedo & 363 \\
\hline Dinxperlo & 443 & Landsmeer & 362 \\
\hline Hardinxveld/Giessendim & 441 & Dostzaan & 360 \\
\hline Wormarveer & 440 & Leiderdorp & 329 \\
\hline Bussum & 438 & Laren (G) & 322 \\
\hline Ambt Delden & 430 & Laren (NH) & 310 \\
\hline Sessenheim & 429 & Naarden & 309 \\
\hline Voorburg & 425 & Koog aan de Zaan & 305 \\
\hline Staphorst & 424 & Son en Breugel & 296 \\
\hline Wijhe & 421 & Blaricum & 292 \\
\hline & & Waalre & 286 \\
\hline & & oiemen & 257 \\
\hline
\end{tabular}


$81 j$ lage VII - 9

Scores factor V: Stedel1jkheid - voorzieningendeprivetie per gemeente

\begin{tabular}{|c|c|c|c|}
\hline \multicolumn{2}{|c|}{ V1erde kwart1el (774-556) } & \multicolumn{2}{|c|}{ Derde kwartiel (555-501) } \\
\hline Gemeenten & Scores & Gemeenten & Scores \\
\hline Leiden & 774 & HordInxveld/Gelssendem & 555 \\
\hline Hearlem & 743 & Grootabroek & 554 \\
\hline Vlaerdingen & 724 & Ommen & 554 \\
\hline Delft & 706 & Gelean & 553 \\
\hline Amham & 705 & Huissen & 553 \\
\hline Groningen & 702 & 2 andvoort & 549 \\
\hline 's-Hertogenbosch & 686 & 's-Gravendeel & 548 \\
\hline Dordrecht & 684 & Hegsch & 544 \\
\hline Voorburg & 683 & Weerselo & 541 \\
\hline Kampen & 672 & Assen & 540 \\
\hline Breda & 672 & R1jssen & 538 \\
\hline Gouda & 666 & Diemen & 538 \\
\hline RIJnsburg & 661 & Heemskerk & 536 \\
\hline Urk & 660 & Ruurlo & 535 \\
\hline Zeendam & 650 & Sittard & 534 \\
\hline Zwolle & 641 & H1llegom & 533 \\
\hline Leeuwarden & 639 & Koog aen de Zaon & 533 \\
\hline Helmond & 625 & Wormerveer & 531 \\
\hline Measdriel & 625 & Dutven & 529 \\
\hline H\$ lversum & 624 & Leiderdorp & 529 \\
\hline Vl1ssingen & 623 & Lemsterlond & 528 \\
\hline Staphorst & 619 & Asten & 528 \\
\hline sliedrecht & 614 & Ambt Delden & 528 \\
\hline Brunssum & 612 & Middelburg & 526 \\
\hline Veldhoven & 599 & Goes & 525 \\
\hline Delfsen & 594 & Beilen & 524 \\
\hline Bungchoten & 591 & Moossluis & 523 \\
\hline Almelo & 589 & Zundert & 522 \\
\hline De Lier & 589 & Harlingen & 521 \\
\hline Markelo & 587 & WaddInxveen & 520 \\
\hline qeventer & 586 & Laren (G) & 520 \\
\hline Hengelo (0) & 576 & Hendrik Ido Ambecht & 516 \\
\hline 's-Grovenzande & 573 & Veenendeal & 515 \\
\hline Tubbergen & 569 & Sneek & 514 \\
\hline Wageningen & 568 & Heerhugoweard & 514 \\
\hline Alkmaar & 566 & Hengelo (G) & 514 \\
\hline Dss & 565 & Alphen aen de RIJn & 513 \\
\hline Zuidwolde & 564 & Leerdam & 512 \\
\hline Eelde & 564 & Schijndel & 511 \\
\hline Zw1 jndrecht & 562 & Weesp & 511 \\
\hline Heemstede & 561 & Wighe & 508 \\
\hline Bus sum & 559 & Zutphen & 506 \\
\hline Valkenswasrd & 556 & E1jgelshoven & 504 \\
\hline Krimpen aan de IJssel & 556 & Heeze & 501 \\
\hline
\end{tabular}


Scores factor V: Stedelijkheid - voorzieningendeprivatie per gemeente

\begin{tabular}{|c|c|c|c|}
\hline \multicolumn{2}{|c|}{ Tweede kwart1el (500-445) } & \multicolumn{2}{|c|}{ Earste kwart1el $(445-223)$} \\
\hline Gemeenten & Scores & Gemeanten & Scores \\
\hline Boxtel & 500 & 01sterwljk & 445 \\
\hline Veghel & 499 & Enkhuizen & 444 \\
\hline Meppel & 498 & Denekamp & 444 \\
\hline Waolre & 498 & Landsmeer & 441 \\
\hline Eersel & 497 & Winschoten & 438 \\
\hline Langedijk & 496 & oldenzaal & 433 \\
\hline Gorinchem & 495 & Eijsden & 433 \\
\hline Boskoop & 495 & IJsselstein & 427 \\
\hline Zelhem & 495 & Driebergen/Rijsenburg & 415 \\
\hline Delfzijl & 494 & Klundert & 412 \\
\hline Elsloo & 493 & H1lvaranbeek & 410 \\
\hline Steenw1jk & 489 & Bergeyk & 406 \\
\hline Zoetermeer & 489 & Vorden & 399 \\
\hline Maerssen & 488 & Zierikzee & 398 \\
\hline Laren (NH) & 488 & Swalmen & 398 \\
\hline E1bergen & 487 & Olst & 394 \\
\hline Borne & 485 & Bolsward & 393 \\
\hline Dubbe l dam & 483 & Cuyk en St. Agatha & 392 \\
\hline Culemborg & 482 & Susteren & 391 \\
\hline Harderwijk & 482 & Dokkum & 384 \\
\hline Heer & 479 & Massbracht & 380 \\
\hline Hoorn & 478 & Zaltbormel & 379 \\
\hline Waalwijk & 473 & Bergen & 379 \\
\hline Didam & 473 & Qude Pekela & 378 \\
\hline Kromente & 473 & Niatwe Pekela & 373 \\
\hline Vinkeveen en Waverveen & 473 & Appingedam & 367 \\
\hline Oost- en West-Souburg & 479 & Ui tgeest & 367 \\
\hline Dostzaan & 471 & Doesburg & 366 \\
\hline Vianen & 470 & Coevorden & 364 \\
\hline Assendelft & 470 & Breukelen & 360 \\
\hline Son en Breugel & 470 & Schoonhoven & 359 \\
\hline Made en Drimelen & 467 & Neede & 349 \\
\hline Hoogkerk & 464 & Purmerend & 335 \\
\hline Roermond & 463 & $A \times B$ & 332 \\
\hline Smilde & 463 & Middelharnis & 317 \\
\hline Baern & 463 & Borculo & 316 \\
\hline Noarden & 461 & Goor & 315 \\
\hline Oud Beiferland & 458 & Lochem & 314 \\
\hline Sassenhelm & 457 & Geldermalsen & 314 \\
\hline Strijen & 456 & Dinxperlo & 296 \\
\hline Holten & 447 & Hulst & 284 \\
\hline Hettem & 447 & Groenlo & 280 \\
\hline Goirle & 448 & Spijkenisse & 266 \\
\hline Blaricum & 446 & Schagen & 223 \\
\hline
\end{tabular}


Bijlage VII - 11

Scores factor VI: Industrie per gemeente

\begin{tabular}{|c|c|c|c|}
\hline \multicolumn{2}{|c|}{ Vierde kwartiel (772-563) } & \multicolumn{2}{|c|}{ Derde kwartiel (560-486) } \\
\hline Gemeenten & Scares & Gemeenten & Scores \\
\hline Krommenie & 772 & Dordrecht & 560 \\
\hline Goor & 765 & Bergeyk & 560 \\
\hline Goirle & 746 & Landsmeer & 552 \\
\hline RiJssen & 731 & Huissen & 551 \\
\hline Wormervear & 723 & 01st & 549 \\
\hline Neede & 719 & Boxtel & 548 \\
\hline Leerdam & 716 & Heeze & 547 \\
\hline Zaandam & 689 & Leiden & 545 \\
\hline Assendelft & 685 & Schoonhoven & 543 \\
\hline Borne & 682 & Tubbergen & 542 \\
\hline Hengelo (0) & 674 & Swalmen & 542 \\
\hline Oldenzaal & 668 & Susteren & 540 \\
\hline Krimpen aan de IJssel & 667 & Heвt & 539 \\
\hline Doesburg & 659 & Markelo & 537 \\
\hline Culemborg & 656 & Veldhoven & 534 \\
\hline Weerselo & 652 & H1lvarenteek & 534 \\
\hline Helmond & 649 & Gauda & 533 \\
\hline Brunssum & 643 & Hoogkerk & 527 \\
\hline Koog aan de Zaan & 635 & Cuyk en St. Agatha & 527 \\
\hline IJsselgtein & 635 & Nieuwe Pekela & 524 \\
\hline Hardinxveld/Giessendam & 632 & Wealre & 520 \\
\hline Dude Pekela & 625 & Eijsden & 520 \\
\hline Schifndel & 624 & Asten & 518 \\
\hline Waalwijk & 620 & Oost- en West-Souburg & 517 \\
\hline Gorinchem & 618 & Eersel & 512 \\
\hline Dinxperlo & 618 & Made en Drimmelen & 512 \\
\hline E1jgelshoven & 616 & Appingedam & 511 \\
\hline Valkenswaerd & 610 & Sp1jken Issa & 511 \\
\hline Groenlo & 606 & Hilversum & 510 \\
\hline Veenendaal & 596 & Vienen & 508 \\
\hline Denekamp & 590 & Barculo & 506 \\
\hline OisterwIjk & 589 & Alphen aan de R1jn & 505 \\
\hline Sliedrecht & 587 & Haorlem & 504 \\
\hline Bunschoten & 587 & Vl1ssingen & 504 \\
\hline Ui tgeest & 586 & Maarsen & 504 \\
\hline Almelo & 585 & Dostzaan & 504 \\
\hline Meessluis & 585 & Zuidwolde & 501 \\
\hline Weesp & 585 & Zwijndrecht & 498 \\
\hline Deventer & 579 & Wageningen & 496 \\
\hline Oss & 577 & Geleen & 495 \\
\hline O1dam & 567 & Zutphen & 491 \\
\hline Vlaardingen & 566 & WaddInxveen & 487 \\
\hline Elbergen & 566 & Leren (G) & 487 \\
\hline Delft & 563 & Oud Befferland & $4 B 6$ \\
\hline
\end{tabular}


Scores factor VI: Industrie per gemeente

\begin{tabular}{|c|c|c|c|}
\hline \multicolumn{2}{|c|}{ Tweede kwart1el $(485-429\}$} & \multicolumn{2}{|c|}{ Eerste kwartial (428-289) } \\
\hline Gemeenten & Scores & Gemeenten & Scores \\
\hline Ambt Delden & 485 & Bussum & 428 \\
\hline Geldermelsen & 485 & Lemstarlend & 427 \\
\hline Hattem & 484 & Sneek & 426 \\
\hline Zelhem & 483 & Maasdriel & 425 \\
\hline Zal tbornmel & 481 & Delfsen & 423 \\
\hline Harlingen & 478 & Diemen & 421 \\
\hline Duiven & 477 & Lochem & 419 \\
\hline Purmerend & 475 & Middelburg & 416 \\
\hline Boskoop & 474 & Assen & 415 \\
\hline Hendrik Ido Ambacht & 472 & Veghel & 415 \\
\hline Heasch & 468 & Hegrhugowaard & 413 \\
\hline Breukelen & 468 & Lengedijk & 412 \\
\hline 's-Hertogenbosch & 467 & Axel & 406 \\
\hline Hengelo. (G) & 466 & Sossenhe1m & 401 \\
\hline Enkhulzen & 466 & Oubbeldam & 397 \\
\hline 's-Gravendeel & 464 & Вearn & 397 \\
\hline Kempeti & 463 & Dokkum & 396 \\
\hline Zwolle & 463 & Goes & 395 \\
\hline Ruurlo & 463 & Zundert & 393 \\
\hline Winschoten & 459 & Coevorden & 393 \\
\hline Vorden & 459 & Ommen & 392 \\
\hline Arnhem & 458 & Vinkeveen en Waverveen & 391 \\
\hline Brede & 458 & 's-Gravenzande & 390 \\
\hline Heengkerk & 458 & Sinilde & 390 \\
\hline Wijhe & 458 & Driebergen/R1jsenburg & 390 \\
\hline Grootebroek & 455 & Bellen & 389 \\
\hline Staphorst & 454 & Roermond & 383 \\
\hline Hoorn & 454 & Herderw1jk & 379 \\
\hline Klundert & 453 & De Lier & 375 \\
\hline Alkmear & 452 & Strijen & 375 \\
\hline Meppel & 451 & Delfz1jl & 370 \\
\hline H1llegorn & 449 & Zierikzee & 367 \\
\hline Elsloo & 448 & Middelharnis & 365 \\
\hline Hulst & 448 & Voorburg & 362 \\
\hline Bolsward & 447 & Schagen & 358 \\
\hline Groningen & 446 & Leiderdorp & 353 \\
\hline Leeuwarden & 446 & Zoetermeer & 351 \\
\hline Son en Brougel & 442 & Heems tede & 349 \\
\hline Urk & 441 & R1jnsburg & 348 \\
\hline Lerøn $\cdot(\mathrm{NH})$ & 439 & Zandvoort & 322 \\
\hline Holten & 437 & Bergen & 319 \\
\hline Steenw1Jk & 433 & Maasbracht & 306 \\
\hline Naarden & 433 & Eolde & 291 \\
\hline Sittard & 429 & Blaricum & 289 \\
\hline
\end{tabular}


A. Nulde-orde correlaties tussen de onafhankelijke variabelen van het operationele model voor zowel de totale ondarzoekspopulatie $(N=176)$ als de hoofdurbenisatiegraadcategorieën plattelandsgemegnten $(N=44)$ en stedelijke gemeenten $(N=70)$.

\section{Variobelen:}

a) aantal inwoners

b) bevolkingsdichitheid

c) index economische diversiteit

d) Index clffersproducerende instenties

e) : beroepsbevolking met meer dan allean lager onderwijs

f) index normatieve intogratie

\section{Correlatiematrices:}

Totale onderzoekspopulatie

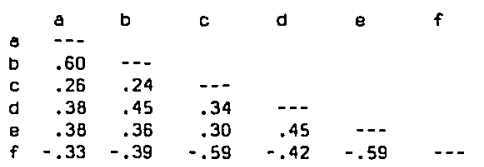

\section{Plattelandsgemeenten}

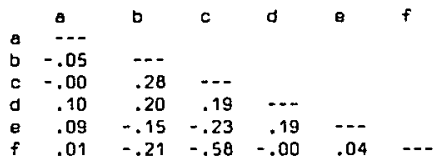

Stedelifke gemeenten

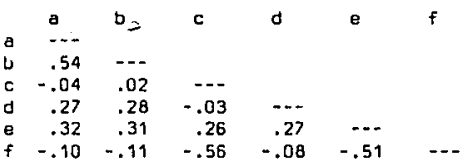

B. Vierde orde correlaties tussen de onofhankelijke veriabelen van het operationele madel voor zowel de totale onderzoekspopulatie $\left(\mathrm{N}^{*}{ }^{-176)}\right.$ als de hoofdurbanisatiegraadcategorieön plattelendsgemeenten $(N=44)$ en stedelijke gemeenten $(N=70)$.

\section{Variabelen:}

a) oental Inwoners

b) bevolkingsdichtheld

c) index economische diversiteit

d) Index ciffersproducerende instanties

e) : beroepsbevolking met meer den alleen lager onderwijs

f) index normatiave integratie

\section{Correlatiematrices:}

Totale onderzoekspopulatie

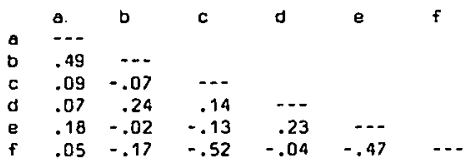

\section{Plattelandsgemeenten}

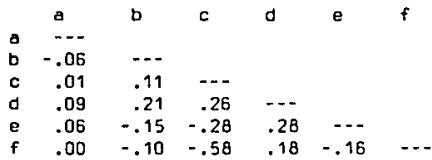

Stedel1jke gemeenten

$\begin{array}{lllllll} & a & b & c & d & e & f \\ b & -. . & & & & & \\ b & .47 & -.- & & & & \\ c & -.10 & .03 & -. . & & & \\ \text { d } & .10 & .13 & -.07 & -. . & & \\ g & .17 & .13 & .02 & .19 & -. . & \\ f & -.01 & .03 & -.05 & .01 & -.43 & -. .\end{array}$


Nulde-ordy correlaties van de onafhankelijke met de afhenkelijke variabelen van het operationele model voor zowel de totale onderzoekspopulatie (N- 176) als de hoofdurbanisatiegraadcategoriean plattelandsgemeenten $(N=44)$ en stedelijke geneenten $(N=70)$.

\section{Onefhankelijke variabelen:}

a) aantal inwoners

b) bevolkingsolchtheld

c) Index economische diversiteit

d) Index ciffersproducerende instanties

e) beroepsbevolk1ng met meer dan alleen leger onderw1js

f) Index normatieve integratie

\section{Afhankelijke varlabelen:}

1) faktor vluchtgedrag

2) faktor egresslef gedrag

3) echtschoidingen

4) zelfmoord

5) vermogensmisorijven

6) egressieve migdrijuen

\section{Correlatiomatrices:}

Totale onderzoeksfopulatie

\begin{tabular}{|c|c|c|c|c|c|c|}
\hline & 1 & 2 & 3 & 4 & 5 & 6 \\
\hline$a$ & .55 & .38 & .60 & -.00 & .54 & -.09 \\
\hline 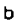 & .55 & .34 & .56 & -.02 & .49 & .03 \\
\hline c & .50 & .12 & .46 & .11 & .30 & .03 \\
\hline d & .49 & .33 & .46 & .00 & .47 & .06 \\
\hline e & .62 & .00 & .59 & .20 & .25 & -.35 \\
\hline$f$ & -.76 & .05 & -.71 & -.38 & -.25 & .25 \\
\hline
\end{tabular}

Plattelandsgemeenten

\begin{tabular}{|c|c|c|c|c|c|c|}
\hline & 1 & 2 & 3 & 4 & 5 & 6 \\
\hline a & .07 & -.05 & .37 & -.15 & .04 & -.20 \\
\hline b & .11 & .45 & .20 & -.38 & .54 & .53 \\
\hline c & .26 & .18 & .19 & .02 & .37 & .18 \\
\hline d & .09 & .23 & .00 & -.04 & .38 & -.09 \\
\hline e & .28 & -.31 & .06 & .29 & -.13 & -.42 \\
\hline$f$ & -.59 & .21 & -.47 & -.32 & .01 & .03 \\
\hline
\end{tabular}

Stedelijke gemeenten

\begin{tabular}{|c|c|c|c|c|c|c|}
\hline & 1 & 2 & 3 & 4 & 5 & 6 \\
\hline a & .61 & .41 & .61 & -.07 & .48 & -.22 \\
\hline & .47 & .30 & .50 & . & .32 & -.07 \\
\hline & .38 & -.19 & .32 & .35 & -.07 & -.23 \\
\hline & .18 & .35 & .14 & .02 & .38 & .15 \\
\hline & .52 & .02 & .48 & .34 & .17 & -.28 \\
\hline & -.51 & .31 & -.37 & -.66 & .11 & .39 \\
\hline
\end{tabular}




\section{LITERATUUR}

ABU-LUGHOD, J.L. (1969): Testing the theory of social area analysis; the ecology of Cairo, Egypt. Amer. Sociol. R. 34, 198-212

AKERS, R.L. (1968): Problems in the sociology of deviance; social definitions and behavior. Soc. Forces $46,455-65$

ALPERT, H. (1952): Suicides and homicides. Amer. sociol. R. 17,673

BECKER, H.S. (1963): Outsiders: studies in the sociology of deviance. New York, Free Press

BENNIS, W.G., and H.A. SHEPHARD (1964): Group observation. In: W.G. Bennis, K.D. Benne and R. Chin (eds.): The planning of change. Reading in the applied behavioral science. New York, Holt, Rinehart and Winston

BION, W.R. (1961): Experience in groups and other papers. London, Tavistock Publications

CLINARD, M.B. (1968): Sociology of deviant behavior;3rd ed. New York, Holt, Rinehart and Winston

COHEN, A.K. (1960): The study of social disorganization and deviant behavior. In: R.K. Merton, L. Broom and L.S. Cottrell Jr. (eds.): Sociology today. New York, Basic books

COHEN, A.K. (1966): Deviance and control. New York, Prentice Hall

DEVRIES, A.G. (1968): Model for the prediction of suicidal behavior. Psychol. Rep. 22, 1285-1302

DODGE, D.L., and W.T. Martin (1970): Social stress and chronic illness. Notre Dame

DROP, M.J. (1970): Kenmerken van gemeenten en verschillen in ziekte en afwijkend gedrag; dimensies in $\mathrm{Co}^{-}$ ping behavior. Sociol. Gids 17, 368-92

DROP, M.J. (1971): Kenmerken van gemeenten en verschillen in ziekte en afwijkend gedrag; resultaten eerste onderzoekfasen. Leiden, NIPG/TNO. Interimrapport 
DROF, M.J. (1972): De geldigheid van de geregistreerde frequenties van afwijkend en ziektegedrag.

Maandbl. Geest. Volksgezondh. 27, 2-11

DROP, M.J. (1973): Problemen rond het registreren van gegevens in de gezondheidszorg. Maandbl. Geest. Volksgezondh. 28, 61-71

DUNCAN, 0.0., and B. DAVIS (1953): An alternative to ecological correlation. Amer. Sociol. Rev. 18, 665-6

DUNCAN, 0.D., and L.E. SCHNORE (1959): Cultural, behavioral and ecological perspectives in the study of social organization. Amer. J. Sociol. 55, 132-46

DUNHAM, H.W. (1964): Anomie and mental disorder. In: M.B.

Clinard (ed.): Anomie and deviant behavior. Glencoe, Ill., Free Press

DUNHAM, H.W. (1968): Epidemiology of psychiatric disorders as a contribution to medical ecology. Int. J. Psychiat. 5, 124-46

DURKHEIM, E. (1952): Suicide: a study in sociology; transl. by J.A. Spaulding and G. Simpson. Chicago, Free Press

DURKHEIM, $E$ (1965): The division of labor in society. New York, Free Press

DYNES, R.R., A.C. CLARKE, S. DINITZ and I. ISHINO (1964): Social problems; dissensus and deviation in an industrial society. New York, Oxford University Press

EDWARDS, A. (1973): Sex and area variations in delinquency rates in an English city. Brit. J. Criminol. $13,121-37$

EKELMANS, J. (1971): De mondige sterveling. Med. Contact $26,791-5$

ELIAS, N.(1939): Ueber den Prozess der Zivilisation. Zweiter Band. Basel, Verlag Haus zum Falken

ELIAS, N. (1971): Was ist Soziologie? München, Juventa Verlag, 2. Auflage 
ERIKSON, K.T. (1962): Notes on the sociology of deviance. Soc. Probl. 9, 307-22

ETZIONI, A., and E.W. LEHMAN (1967): Some dangers in "valid" social measurement. A. Amer. Acad. Polit. Soc. Sci. 373, 1-15

FARIS, R.E.L., and H.W. DUNHAM (1939): Mental disorders in urban areas. Chicago, University Press

FEBER, G.H.A. (1933): De criminaliteit der Katholieken in Nederland. Roermond-Maaseik, Romen \& Zn.

FEBER, G.H.A. (1940): De criminaliteit onder de Katholieken in Nederland. Praeadvies, uitgebracht voor de Rechtskundige afdeling der Katholieke Wetenschappelijke Vereniging. 's-Gravenhage, Ten Hagen

FENELON, B. (1971): State variations in United States divorce rates. J. Marr. Fam. 33, 321-7

GALLE, O.R., W.R. GOVE and J.M. McPHERSON (1972): Population density and pathology; what are the relations for man? Science 176, 23-30

GALTUNG,J. (1969): Theory and methods of social research; 2nd ed. London, Allen and Urwin

GARDNER, M.J., M.D. CRAWFORD and J.N. MORRIS (1969): Patterns of mortality in middle and early old age in the county boroughs of England and Wales. Brit. J. Prev. Soc. Med. 23, 133-40

GERARD, D.L., and L.G. HOUSTON (1953): Family setting and the social ecology of schizophrenia. Psychiat. Quart. 27, 90-101

GIBBS, J.P. (1962): Rates of mental hospitalization: a study of societal reaction to deviant behavior. Amer. Sociol. Rev. 27, 782-92

GIBBS, J.P., and W.T. MARTIN (1958): A theory of status integration and its relationship to suicide. Amer. Sociol. Rev. 23, 140-7

GIBBS, J.P., and W.T. MARTIN (1966): On assessing the theory of status integration and suicide. Amer. Sociol. Rev. 31, 533-41 
GIDDENS, A. (1978): Durkheim. Glasgow, William Collins Sons and Co. Ltd.

GOLD, M. (1958): Suicide, homicide and the socialization of agression. Amer. J. Sociol. 23, 651-61

GOODE, W.J.(1961): Illegitimacy, anomie and cultural penetration. Amer. Sociol. Rev. 26, 910-25

GOODMAN, L.A. (1953): Ecological regression and behavior of individuals. Amer. Sociol. Rev. 18. 663-4

GORDON, R.E., and K.K. GORDON (1960): Social psychiatry of a mobile suburb. Intern. J. Soc. Psychiatr. $6,89-100$

GOVE, W.R. (1970): Societal reaction as an explanation of mental illness; an evaluation. Amer. Sociol. Rev. 35, 873-84

GRAAF, C.J.A.W. DE (1973): Multi-nivo analyse. Problemen bij de analyse van gegevens van onderzoekseenheden van verschillend nivo. Soc. Wetensch. 16, 168-89

GROOT, A.D. DE (1961): Methodologie. Den Haag, Mouton HADDEN, J.K., and E.F. BORGATTA (1965): American Cities; their social characteristics. Chicago, Rand McNalley

HARE, E.H. (1956): Mental Illness and social conditions in Bristol. J. Mental Sci. 102, 349-51

HAVERDA, J.L. (1955): Het relativiteitsprobleem van afwijkend gedrag. Sociol. Gids 2, 125-9

HAVERMANS, F.M. (1953): Over de criminaliteit onder Katholieken. Roermond-Maaseik, Romen \& $\mathrm{Zn}$.

HEEK, F. VAN (1954): Het geboorteniveau der Nederlandse Rooms-Katholieken. Leiden, Stenfert Kroese

HENRY, A.F., and J.F. SHORT Jr (1954): Suicide and homicide. Glencoe, Ill., Free Press

HOWARD, A., and R.A. SCOTT (1965): A proposed framework for the analysis of stress in the human organism. Behav. Sci. 10, 141-60 
HYDE, R.W., and L.V. KINGSLEY (1944a): Studies in medical Sociology I: the relation of mental disorders to the community socioeconomic level. New Engl. J. Med. 231, 543-8

HYDE, R.W., and L.V. KINGSLEY (1944b): Studies in medical sociology II: the relation of mental disorders to population density. New Engl. J. Med. 231, 571-7

JANSON, C.G. (1968): The spatial structure of Newark, New Yersey. Part I: the central city. Acta Sociol. 11, 144-69

JONASSEN, C.T., and S.H. Peres (1960): Interrelationships of dimensions of community systems; a factoranalysis of eighty-two variables. Ohio, State University Press

JONGMAN, R.W., W. BUIKHUIZEN en W. OVING (1969): Ongeregistreerde criminaliteit bij studenten. Ned. T. Criminol. 11, 69-89

KAPLAN, B., R.B. REED and W. RICHARDSON (1956): A comparison of the incidence of hospitalized and nonhospitalized cases of psychosis in two communities. Amer. Sociol. Rev. 21, 472-9

KEMPE, G.Th. (1938): Criminaliteit en kerkgenoodschap. Utrecht, Dekker en Van der Vegt

KERLINGER, F.N. (1966): Foundations of behaviorall research. New York, Holt, Rinehart and Winston

KITSUSE, J.I. (1962): Societal reaction to deviant behavior: problems of theory and method. Soc. Probl. $9,247-56$

KITSUSE, J.I., and A.V. CICOUREL (1963): A note on the use of official statistics. Soc. Probl. 11, $131-9$

KRUYT, C.S. (1960): Zelfmoord, statistisch-sociologische verkenningen. Assen, Van Gorcum

KRUYT, J.P. (1943): Mentaliteitsverschillen in ons volk in verband met godsdienstige verschillen. Mens en Maatschappij 19, 1-28 
LEMERT, E.M. (1951): Social pathology, New York, McGraw Hill LIEBERSON, S. (1969): Measuring population diversity. Amer. Sociol. Rev. 34, 850-62

LINSKY, A.S. (1970): Community homogeneity and exclusion of the mentally ill; rejection versus consensus about deviance. J. Hlth. Soc. Behav. 11, 304-11

MARTIN, A.E. (1967): Environment, housing and health. Urb. Stud. 4, 1-21

MCDILL, E.L., and S.J.C. RIDLEY (1962): Status, anomia, political alienation and political participation. Amer. J. Sociol. 68, 205-13

MCDONALD, R.P., and E.J. BURR (1967): A comparison of four methods of constructing factor scores. Psychometrika 32, 381-401

MENZEL, H. (1950): Comment on Robinson's 'Ecological correlations and the behavior of individuals'. Am. Sociol. Rev. 15, 674

MERTON, R.K. (1961): Social theory and social structure. Glencoe, Ill, Free Press

MERTON, R.K., and R.A. NISBET (eds) (1961): Contemporary social problems. New York, Harcourt, Brace and World

MILEY, J.D., and M. MICKLIN (1972): Structural change and the Durkheimian legacy; a macrosocial analysis of suicide rates. Amer. J. Sociol. $78,657-73$

MODTZ, M., en A.P.N. NAUTA (1977): Planning and development in the Netherlands.

9. 50-66

MOSER, C.A., and W. SCOTT (1961): British towns. A statistical study of their social and economic differences. Edinburgh, Boyd

MUNSON, B.E. (1968): Structural analysis of the community. Rur. Sociol. 33, 450-60

MURPHY, H.B.M. (1961): Social change and mental health. Milb. Memor. Fund Quart. 39, 385-445 
NEDERLANDSE STAATSCOURANT (1975): Aanwijzing inzake de bescherming van de persoonlijke levenssfeer, woensdag 12 maart, 4-6

NELISSEN, N.J.M. (1972): Grondbeginselen van de sociale ecologie. Utrecht, Het Spectrum. Aula-: pocket 473

PETRAS, J.W., and J.E. CURTIS (1968): The current literature on social class and mental disease in America; critique and bibliography. Behav. Sci. 13, $383-98$

PETTIGREW, T.F., and R. BARCLAY SPIER (1952): The ecological structure of negro homicide. Amer. J. Sociol. 57, 621-9

PHILIPSEN, H. (1969): Afwezigheid wegens ziekte: een onderzoek naar oorzaken van verschillen in ziekteverzuim tussen 83 middelgrote bedrijven. Wolters-Nordhoff, Groningen

PHILIPSEN, H. (1969a): Steekproeven. Inaugurele rede. Universitaire Pers Leiden

PHILIPSEN, H. (1970): Afwijkend gedrag, etikettering door de samenleving en strategieën van de afwijkers. Sociol. Gids 17, 350-67

PHILLIPS, L., and M.S. RABINOVITCH (1958): Social role and patterns of symptomatic behaviors. J. Abnorm. Soc. Psychol. 57, 181-6

POKORNY, A.D. (1965): Human violence: a comparison of homicide, aggravated assault, suicide and attempted suicide. J. Crim. Law', Criminol. Police Sci. 56, 488-97

PQRTERFIELD, A.L. (1951/52): Suicide and crime in folk and in secular society. Amer. J. Sociol. 57, $331-8$

PORTERFIELD, A.L. (1952): Suicide and crime in the social structure of an urban setting; Fort Worth 1930-1950. Amer. Sociol. Rev. 17, 341-9

PORTERFIELD, A.L. (1960): Traffic fatalities, suicide and homicide. Amer. Sociol. Rev. 25, 897-901 
QUINNEY, R. (1965): Suicide, homicide and economic development. Soc. Forces 43, 401-6

RIKE, P. (1972): Pornografie: feiten en verboden. Maandbl. Geest. Volksgez. 27, 111-9

ROBINSON, W.S. (1950): Ecological correlations and the behavior of individuals. Amer. Sociol. Rev. $15,351-7$

ROCK, P., and M. McINTOSH (eds.) (1974): Deviance and social control. London, Tavistock Publ.

ROGERS, E.S. and H.B. MESSINGER (1967): Human ecology; toward a holistic method. Milb. Memor. Fund Quart. 45, 25-42

ROOY, H. VAN (1940): De criminaliteit onder de Katholieken in Nederland. Praeadvies, vitgebracht aan de Rechtskundige Afdeling van de Katholieke Wetenschappelijke Vereeniging. 's-Gravenhage, Ten Hagen

ROSENZWEIG, S. (1945): An outline of frustration theory. In: J. McV. Hunt (ed.): Personality and the behavior disorders. Vol. I. New York, Ronald.

ROSENZWEIG, S., E.E. FLEMING, and H.J. CLARKE (1947): Revised scoring manual for the Rosenzweig PictureFrustration study. J. Psychol. 24, 165-208

RUSHING, W.A. (1969): Deviance, interpersonal relations and suicide. Hum. Relat. 22, 61-76

RUSHING, W.A. (1971): Individual resources, societal reaction and hospital commitment. Amer. J. Sociol. $77,511-25$

SCHEFF, Th.J. (1964): Social conditions for rationality: how urban and rural courts deal with the mentally ill. Amer. Behav. Sci. 7, 21-7

SCHEFF, Th.J. (1966): Being mentally ill. Chicago, Aldine SCHMID, C.F., and K. TAGASHIRA (1964): Ecological and demographic indices; a methodological analysis. Demography 1, 194-211 
SCHMITT, R.C. (1957): Population density and mental disorders in Honolulu. Hawaii Med. J. 16, 396-7

SCHMITT, R.C. (1966): Density, health and social disorganization. J. Amer. Inst. Planners 32, 38-40

SCHUR, E.M. (1969): Reactions to deviance; a critical assessment. Amer. J. Sociol. 75, 309-22

SEIBEL, H.D. (1972): Abweichendes Verhalten und sozial Integration. Kölner 2 . Soziol. Soz. Psych. 24, $1-23$

SELG, H., und G. LISCHKE (1966): Eine Faktoranalyse von Agressionsvariabelen. Z. Exp. Angew. Psychol. 13, 506-26

SELLIN, Th. (1951): The significance of records of crime. Law Quart. Rev. 67, 596-604

SENAY, E.C., and F.C. REDLICH (1968): Cultural and social factors in neuroses and psychosomatic illnesses. Soc. Psychiat. 3, 89-97

SHEVKY, E., and W. BELL (1955): Social area analysis; theory, illustrative application and computational procedures. Stanford University Series in Sociology $n r$. I, Stanford Univ. Press

SHEVKY, E., and M. WILLIAMS (1949): The social areas of Los Angelos; analysis and typology. Los Angelos, Berkeley, University Press

SHULMAN, H.M. (1966): The measurement of crime in the United States. J. Crim. Law, Criminol. Police Sci. 57, 483-92

STEIGENGA. W. (1955): A comparative analysis and a classification of Netherlands towns. T. Econ. Soc. Geogr. 46, 105-19

STOUTHARD, P.C. (1973): Besprekingsartikel van C.W. Aakster's proefschrift. Soc. Wetensch. 16. 55-63

SWEETSER, F.L. (1965): Factor structure as ecological structure in Helsinki and Boston. Acta Sociol. 8, 205-25 
SZASZ, T.S. (1970): The manufacture of madness: a comparative study of the inquisition and the mental health movement. New York, Harper and Row

THOMPSON, W.E., and J.E. HORTON (1960): Pälitical alienation as a force in political action. Soc. Forces $38,190-5$

THORNDIKE, E.L. (1939): Your city. New York, Harcourt, Brace THORNDIKE, E.L. (1940): 144 small cities. New York, Harcourt, Brace

TIMASHEFF, N.S. (1957): Sociological theory; its nature and growth. New York, Random House

TURK, A.T. (1966): Conflict and criminality. Amer. Sociol. Rev. 31, 338-52

VEREENIGING TOT HET BEVORDEREN VAN DE BEOEFENING DER WETENSCHAP ONDER DE KATHOLIEKEN IN NEDERLAND (1941): Gedachtenwisseling over de criminaliteit onder de Katholieken in Nederland door Mr.Dr. G.H.A. Feber en Dr. H. van Rooy O.F.M.. 's-Gravenhage, Ten Hagen

WAGNER, H.R. (1964): Displacement of scope: a problem of the relationship between small-scale and largescale sociological theories. Amer. J. Sociol. $69, \quad 517-84$

WEBB, S.D. (1972): Crime and the division of labor; testing a Durkheimian model. Amer. J. Sociol. 78, 643-56

WECHSLER, H. (1961/62): Community growth, depressive disorders and suicide. Amer. J. Sociol. 67, $9-16$

WERINGH, J. VAN (1968): Criminaliteit en kerkelijke gezindte, enige heroriënterende opmerkingen. Ned. T. Criminol. 10, 1-14

WERKGROEP NATIONAAL CENTRUM GEESTELIJKE VOLKSGEZONDHEID (1972):

De vragenlijst over zedelijkheidswetgeving; een critisch commentaar. Maandbl. Geest. Volksgez. $27,102-10$ 
WHITT, H.P., C.C. GORDON and J.R. HOFLEY (1972): Religion, economic development and lethal agression. Amer. Sociol. Rev. 37, 193-201

WILLER, D. (1967): Scientific sociology. Englewood Cliffs, N.J., Prentice Hall

WINSLOW, R.W. (1970): Society in transition; a social approach to deviancy. New York, Free Press

ZIGLER, E., and L. PHILLIPS (1960): Social effectiveness and symptomatic behavior. J. Abnorm. Soc. Psychol. 61, 231-8

ZOLA, I.K. (1972): The medicalizing of society: medicine as an institution of social control. Leiden, NIPG/TNO 
DANKWOORD

Bij deze gelegenheid wil ik graag mijn dank uitspreken voor de hulp en steun, die ik bij de uitvoering, rapportage en produktie van deze studie van zovelen heb mogen ontvangen.

Prof.Dr. H. Philipsen ben ik zeer erkentelijk voor het vertrouwen dat hij gedurende deze studie in mij heeft willen stellen en voor de grondige wijze waarop hij het eindprodukt heeft bestudeerd. Zijn positieve kritiek is de kwaliteit van deze publikatie zeer ten goede gekomen. Mijn grote waardering gaat ook uit naar de beide coreferenten,

Prof.Dr. C.E. Vervoort voor zijn snelle en interessante kommentaar, dat zeker tot nadere diskussie uitnodigt;

Prof.Dr. M.A.J. Romme, voor de vele tijd die hij aan de bestudering van het manuscript heeft willen besteden. Prof.Dr. J.A.C. de Kock van Leeuwen, ten tijde van het onderzoek direkteur van het Nederlands Instituut voor Preventieve Geneeskunde/TNO en Prof.Dr. J. Koekebakker, hoofd van de toen nog bestaande afdeling Geestelijke Gezondheid, ben ik dankbaar voor hun medewerking waardoor het mogelijk werd deze studie te ondernemen.

Mevr. Drs. H. Merens-Riedstra en Drs. J. van der Zee ben ik bijzonder erkentelijk voor de inspanningen, die zij zich als student-assistenten voor het projekt hebben getroost. Beste Henriëtte en Jouke, zonder jullie volhardende ijver en vindingrijkheid zouden vele telefoontjes niet zijn gepleegd, vele instanties niet zijn bezocht, kaarten niet zijn getekend en, belangrijker, veel gegevens niet zijn verzameld. Hiervoor wil ik jullie graag bedanken.

Prof.Dr. R. van der Vlist, destijds adjunkt-direkteur van het N.I.P.G./TNO dank ik voor zijn durende belangstelling en voor de kritische wijze warop hij zich met mijn onderzoek heeft willen bezighouden.

Dr. M.J. Hartgerink, de huidige direkteur van het instituut, ben ik dank verschuldigd voor de aandacht die hij aan de concept-teksten van deze studie heeft willen geven en voor zijn stimulerend kommentaar.

Met grote waardering wil ik melding maken van de zeer plezierige en welwillende wijze waarop vele medewerkers van het N.I.P.G./TNO destijds hun medewerking aan projekt 467 hebben verleend. Speciaal wil ik noemen Mevr. M. Schaap (bibliotheek), 
P. van Leeuwen, W. van Nooten en J.J. Radder (statistische advizzen), J. Hendriks (mechanische data-bewerking), P. Hop (computer-programmering) en Mevr. H.S.G. Nooy van der Kolff (hoofd typekamer) -ieder van hen heeft op eigen wijze haar of zijn deskundigheid ter beschikking gesteld en een belangrijke bijdrage aan het onderzoek geleverd. De medewerking van de vele instanties, die de gegevens voor het onderzoek hebben geleverd, heb ik bijzonder op prijs gesteld. Ik ben mij ervan bewust dat zonder deze medewerking het projekt nooit tot uitvoering zou zijn gekomen. Hier dient nog te worden vermeld, dat de computerbewerkingen van deze gegevens zijn verricht op het Centraal Rekeninstituut van de Rijksuniversiteit Leiden. Dok de eindrapportage van het onderzoek en de vormgeving daarvan vergden de medewerking van velen. De aandacht en tijd, besteed aan de voltooiing van deze dissertatie pleegden een zware aanslag op het begrip en geduld van de medewerkers van de capaciteitsgroep Medische Sociologie en van het Memic. Hun lankmoedigheid en morele steun vormden essentiële voorwaarden voor de totstandkoming van dit werk. Ik ben hen hiervoor zeer dankbaar. Mijn bijzondere dank gaat ook uit naar:

Mevr. F.E.C. Hartjesveld en mevr. H. Hageman, die de concept-tekst typten;

Mevr. L. Royen-Warnars voor de wijze waarop zij zich van de zware taak van het typen van de definitieve tekst heeft gekweten;

De heer C. Voskamp voor zijn adviezen voor de lay-out en vormgeving van deze publikatie;

De heer G. van Rooij, die met bekwame spoed de bijlagen en de tabellen fotografeerde en ook de omslag van deze publikatie heeft ontworpen en getekend;

De heer B. Meerstad voor de blijmoedige wijze waarop hij een aantal vrije avonden heeft willen besteden aan het drukken van dit werk.

Mevr. E.J. Deutekom tenslotte, dank ik van harte voor het tekenen van de tabellen en de schema's. Als mijn vriendin heeft zij mij ook in vele andere opzichten haar onmisbare steun gegeven en de lasten helpen dragen. 


\section{CURRICULUM VITAE}

Overeenkomstig het gebruik aan de Fakulteit der Geneeskunde volgt hier een beknopt overzicht van mijn academische studie.

Na het behalen van mijn einddiploma H.B.S. $-A$ aan de Eerste Christelijke H.B.S. te 's-Gravenhage in 1954, ben ik in 1956 begonnen met de studie in de westerse sociologie aan de Rijksuniversiteit te Leiden. Het kandidaatsexamen legde ik af in februari 1960.

In 1963 werd ik als student-assistent halftijds aangesteld bij het zgn. Talentenprojekt onder leiding van Prof.Dr. F. van Heek.

In mei 1964 behaalde ik cum laude het doktoraalexamen westerse sociologie met als hoofdvak Empirische en Wijsgerige Sociologie (Prof.Dr. F. van Heek en Prof.Dr. R.F. Beerling) en als bijvakken Sociale Psychologie (Prof.Dr. J.A.A. van Leent) en Sociologische Theorie (Prof.Dr. H.P.M. Goddijn). Als wetenschappelijk ambtenaar bleef ik tot maart 1967 werkzaam aan het 'Talentenprojekt' op het Sociologisch Instituut van de Rijksuniversiteit Leiden.

Van oktober 1967 tot oktober 1974 was ik als wetenschappelijk medewerker verbonden aan het Nederlands Instituut voor Preventieve Geneeskunde/TNO te Leiden.

Sedert januari 1975 ben ik als wetenschappelijk hoofdmedewerker verbonden aan de Rijksuniversiteit Limburg. 